Pacific Northwest

National Laboratory

Operated by Battelle for the

U.S. Department of Energy

\section{Characterization of the Near-Field Transport and Dispersion of Vapors Released from the Headspaces of Hanford Site Underground Storage Tanks}

J. G. Droppo

July 2004

Prepared for the U.S. Department of Energy

under Contract DE-AC06-76RL01830 


\title{
DISCLAIMER
}

This report was prepared as an account of work sponsored by an agency of the United States Government. Neither the United States Government nor any agency thereof, nor Battelle Memorial Institute, nor any of their employees, makes any warranty, express or implied, or assumes any legal liability or responsibility for the accuracy, completeness, or usefulness of any information, apparatus, product, or process disclosed, or represents that its use would not infringe privately owned rights. Reference herein to any specific commercial product, process, or service by trade name, trademark, manufacturer, or otherwise does not necessarily constitute or imply its endorsement, recommendation, or favoring by the United States Government or any agency thereof, or Battelle Memorial Institute. The views and opinions of authors expressed herein do not necessarily state or reflect those of the United States Government or any agency thereof.

\author{
PACIFIC NORTHWEST NATIONAL LABORATORY \\ operated by \\ BATTELLE \\ for the \\ UNITED STATES DEPARTMENT OF ENERGY \\ under Contract DE-AC05-76RL01830
}

Printed in the United States of America
Available to DOE and DOE contractors from the Office of Scientific and Technical Information,
P.O. Box 62, Oak Ridge, TN 37831-0062;
ph: (865) 576-8401
fax: $(865)$ 576-5728
email: reports@adonis.osti.gov

\begin{abstract}
Available to the public from the National Technical Information Service, U.S. Department of Commerce, 5285 Port Royal Rd., Springfield, VA 22161 ph: (800) 553-6847 fax: $(703) 605-6900$ email: orders@ntis.fedworld.gov online ordering: http://www.ntis.gov/ordering.htm
\end{abstract}

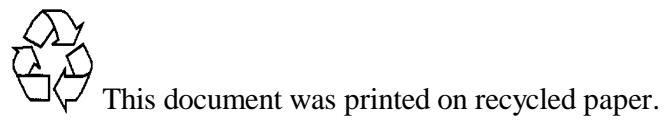




\section{Characterization of the Near-Field Transport and} Dispersion of Vapors Released from the Headspaces of Hanford Site Underground Storage Tanks

J. G. Droppo

July 2004

Prepared for

the U.S. Department of Energy

under Contract DE-AC06-76RL01830

Pacific Northwest National Laboratory

Richland, Washington 99352 


\section{Summary}

A parametric air dispersion analysis is conducted to define the range of tank vapor concentrations that can potentially occur in worker breathing zones from active and passive releases from the waste tanks. The potential influences of tank farm-specific release characteristics, ambient meteorological conditions, local farm surface roughness, and topographical influences are considered. The analysis considers the nearfield concentration resulting from the characteristics of the initial release and the downwind transport and dispersion of released material.

At issue are the maximum concentrations of tank vapors as a function of distance from the source under various meteorological conditions, which meteorological conditions increase the risk of worker exposures, and whether any known sources represent currently unrecognized risks.

Tanks are either passively or actively vented. Trace studies have quantified the relatively slow venting rates of the air in the headspace of the passively vented tanks. Air vented from all the tanks contains vapors. The concentrations of those vapors will be equal to, or very close to, the vapor concentrations in the headspace.

The emphasis in this analysis is to understand the magnitudes and mechanics of potential exposures to people working in the immediate area downwind of the tank vents. Peak concentrations over a few seconds time period can involve exposure to relatively undiluted air from the tank. Such exposures are limited to being quite localized because of the very small volumes of air. Average peak concentrations for longer periods will be lower reflecting the time a worker is in the plume and the effect of ambient atmospheric turbulence on the concentrations in the plume.

The initial release characteristics such as height, area, velocity, temperature, vent orientation, and wake influences will determine the initial dilution and movement of the vented air. Three configurations for tank releases are considered: 1) near-ground passive vents, 2) elevated forced-air stacks, and 3) elevated passive stacks. The 242-A evaporator stack is also considered.

The near-field results are expressed as concentration fractions of headspace concentrations. The air concentrations of a specific vapor may be obtained by multiplying by the headspace concentration of that vapor. The releases of headspace air by passive or forced ventilation are considered for the range of possible environmental parameters.

The predicted changes in plume height are sufficiently small such that it can be concluded that there is insignificant plume rise for all releases. In most cases the wake of the release pipe or structure will result in a plume height slightly lower than the release height. The distance for the plume to diffuse down to the breathing space is about the same for the various stacks including the evaporator stack. That distance is shown to be highly dependent on ambient conditions.

Although the exit velocities for all vents and stacks are relatively small, the volume of that air released is an important parameter in terms of how quickly the plume concentrations decrease downwind. The passively vented tanks have relatively low ventilation rates compared to the forced-air stack ventilation 
rates. The greater the volume per time, the greater the distances that the concentrations from the headspace are expected to continue to exist.

In the vicinity of the release vents, short-duration concentrations at, or near to, the concentrations in the headspace are expected in the breathing space. The random nature of atmospheric turbulence makes this occurrence possible for both near-surface vent and stack releases. The average computed plume concentrations provide relative indications of the decreasing likelihood of such exposures as a function of downwind distance. The forced-air plumes from the stacks showed a much greater relative persistence of initial concentrations than the passive plumes.

There is little possibility of significant plume rise for any of the tank releases of headspace air. In terms of the downwind concentration profiles, there is a consistency within the results for the two types of releases: forced-air stack and passive vent tanks. The passive stack vent is physically much like the forced-air stacks except that ventilation occurs by natural processes such as winds, temperature differences, and ambient pressure changes.

For stack releases, the ground-level concentrations are very low in the breathing zone. The plume centerline concentrations will normally travel above the breathing zone. Under special conditions these plumes may be carried down into the breathing zone or intersect locations on surrounding terrain making the exposure to peak concentrations possible. For surface releases, the volume of air involved is small. If a person is exposed to a high concentration it will be only for a short duration - given the small volume that will need to be maintained for such occurrences.

Other release and dispersion factors will not change the peak concentrations but can increase the average concentrations. Plume pooling will not occur as the result of the thermal properties of the released headspace air. If the released air is incorporated in pooling of air around the tank farm, the small volumes of the release greatly limits any potential impacts. During times with wind directions aligned with tank vents, the combination of plumes from different vents will not increase the potential peak exposures but can if the plumes merge increase in an approximately additive fashion the average plume vapor concentrations.

The results indicate that occasional short-duration exposures of up to several seconds to relatively undiluted headspace air can be expected in the immediate vicinity of the tank vents. Average concentrations that represent diffusion, as well as spatial averaging, fall off rapidly with distance for the passive vents and to a lesser extent for the forced-air stacks. The addition of the influence of the surface roughness elements on the tank farms will result in a faster decrease of concentrations with downwind distance. 


\section{Acknowledgments}

This work was supported by the U.S Department of Energy under Contract DE-AC06-76RL01830 with project funding provided by $\mathrm{CH} 2 \mathrm{M}$ HILL. Special thanks go to James Huckaby for his technical assistance and expert advice. 


\section{Contents}

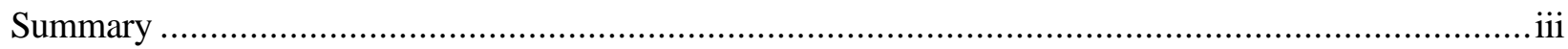

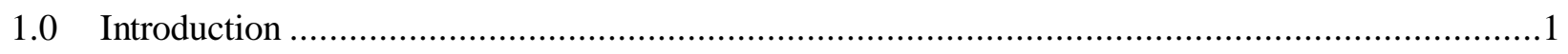

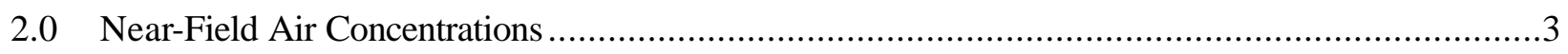

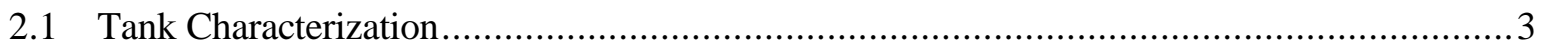

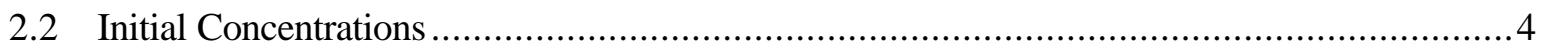

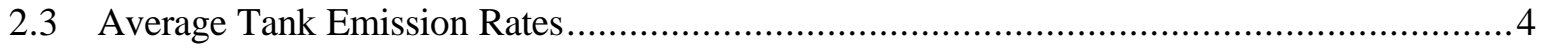

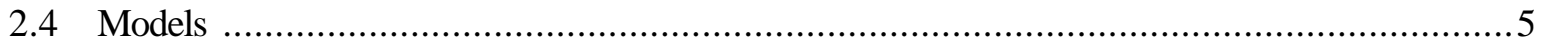

2.5 Peak and Average Concentrations ................................................................ 6

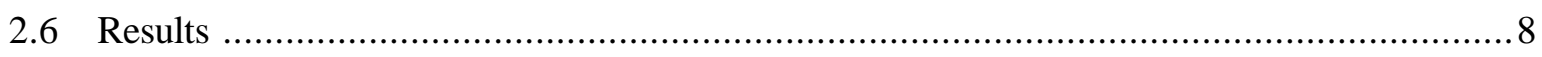

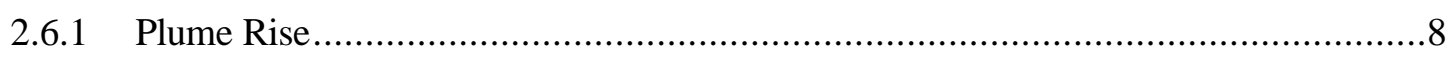

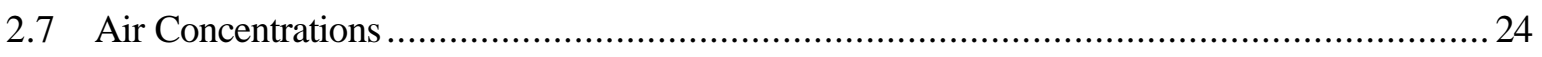

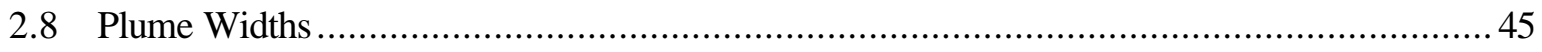

3.0 Additional Release and Dispersion Processes ...................................................... 47

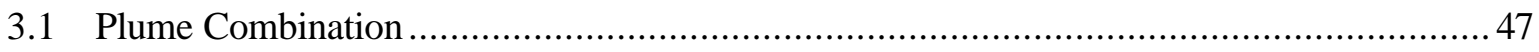

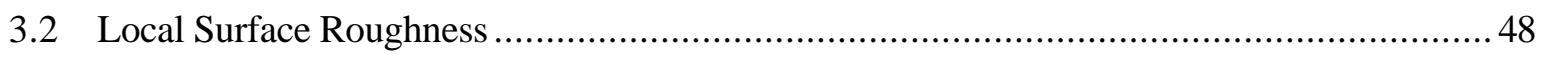

3.3 Interconnected Passively Vented Tanks................................................................. 49

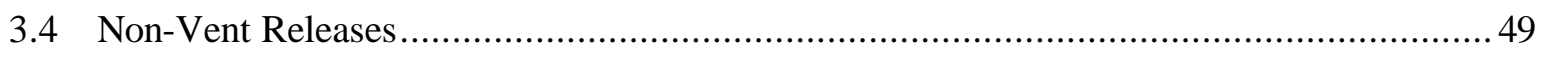

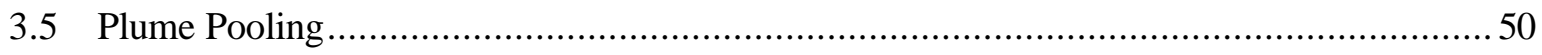

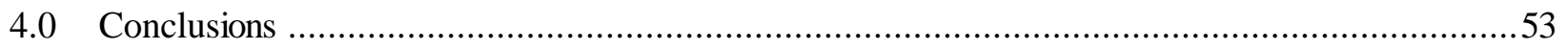

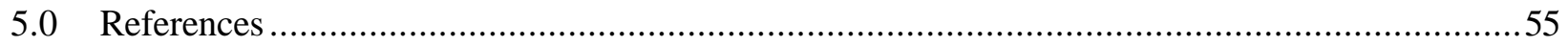




\section{Figures}

1 Range of Tank Ventilation Rates from 1996-1998 Tracer Studies ...............................................4

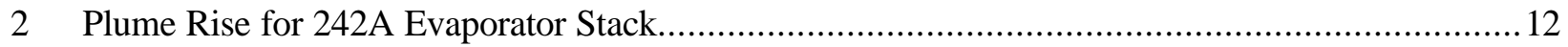

3 Computed Plume Rise for Near-Surface Box Vents with No Buoyancy.................................... 13

4 Computed Plume Rise for Near-Surface Box Vents with Moderate Buoyancy............................. 14

5 Computed Plume Rise for Near-Surface Box Vents with Maximum Buoyancy............................15

6 Computed Plume Rise for Near-Surface Pipe Vents with No Buoyancy.................................... 16

7 Computed Plume Rise for Near-Surface Pipe Vents with Moderate Buoyancy............................. 17

8 Computed Plume Rise for Near-Surface Pipe Vents with Maximum Buoyancy .......................... 18

9 Computed Plume Rise for Passively Vented Stacks ........................................................ 19

10 Computed Plume Rise for AN Tanks Farm Stacks...............................................................2 20

11 Computed Plume Rise for AY/AZ and SY Tank Farm Stacks..................................................21

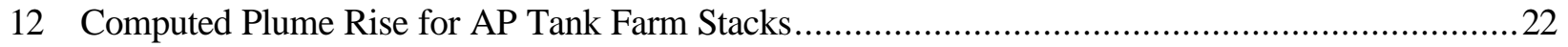

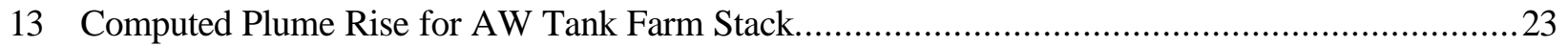

14 Fractional Air Concentrations under Unstable Low-Wind Speed Conditions: AN Tank Farms.......25

15 Fractional Air Concentrations under Unstable Low-Wind Speed Conditions: AP and

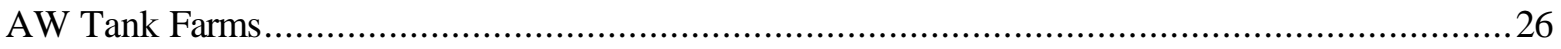

16 Fractional Air Concentrations under Unstable Low-Wind Speed Conditions: AY/AZ,

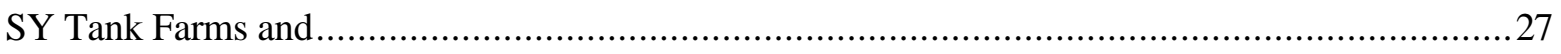

17 Fractional Air Concentrations under Unstable Low-Wind Speed Conditions: Near-Surface Passive Vents................................................................................................28

18 Fractional Air Concentrations under Unstable Low-Wind Speed Conditions: Passively

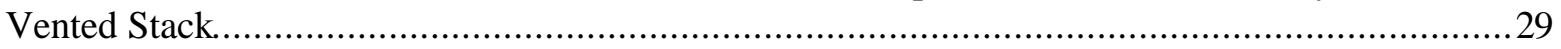

19 Fractional Air Concentrations under Stable Low-Wind Speed Conditions: AN Tank

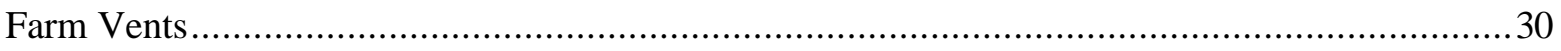

20 Fractional Air Concentrations under Stable Low-Wind Speed Conditions: AP and AW Tank

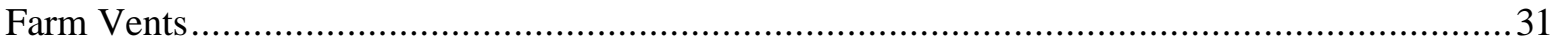

21 Fractional Air Concentrations under Stable Low-Wind Speed Conditions: AY/AZ, SY Tank Farms and 242 A Evaporator Stack............................................................................. 32

22 Fractional Air Concentrations under Stable Low-Wind Speed Conditions: Near-Surface

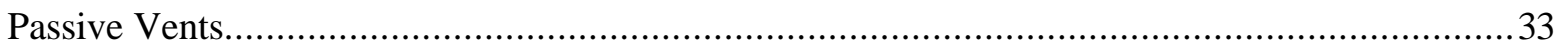

23 Fractional Air Concentrations under Stable Low-Wind Speed Conditions: Passively Vented

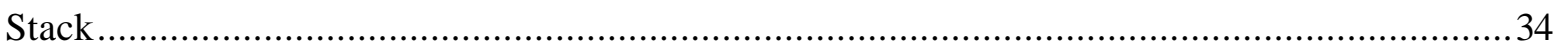

24 Fractional Air Concentrations under Unstable High-Wind Speed Conditions: AN Tank Farm Vents

25 Fractional Air Concentrations under Unstable High-Wind Speed Conditions: AP and AW Tank

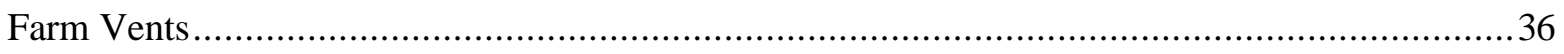

26 Fractional Air Concentrations under Unstable High-Wind Speed Conditions: AY/AZ, SY Tank

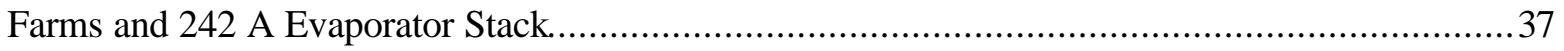

27 Fractional Air Concentrations under Unstable High-Wind Speed Conditions: Near-Surface Passive Vents. 
28 Fractional Air Concentrations under Unstable High-Wind Speed Conditions: Passively Vented Stack.

29 Fractional Air Concentrations under Stable High-Wind Speed Conditions: AN Tank Farm ...........40

30 Fractional Air Concentrations under Stable High-Wind Speed Conditions: AP and AW Tank

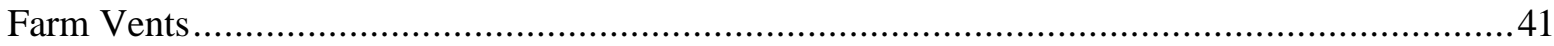

31. Fractional Air Concentrations under Stable High-Wind Speed Conditions: AY/AZ, SY Tank Farms and

32 Fractional Air Concentrations under Stable High-Wind Speed Conditions: Near-Surface Passive

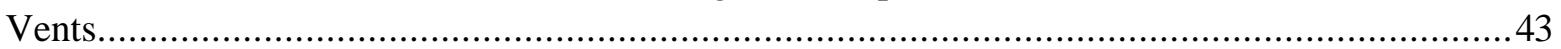

33 Fractional Air Concentrations under Stable High-Wind Speed Conditions: Passively Vented Stack.

\section{Tables}

1 Tank and 242A Evaporator Stack/Vent Exit Flow Parameters ...........................................

2 Summary of Observed Tank Vent/Stack Exit Temperatures ............................................ 10

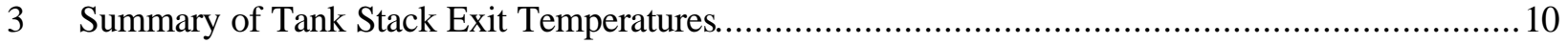

4 Tank Farm Stack Exit Air Temperatures............................................................................ 11

5 Plume Wid ths Expressed as Percentage of a 90-Degree Downwind Sector ................................46 


\subsection{Introduction}

A parametric air dispersion analysis has been conducted to define the range of tank vapor concentrations from the Hanford Site underground tanks that can potentially occur in the worker breathing zones from active and passive releases from the waste tanks. The potential influences of tank farm-specific release characteristics, ambient meteorological conditions, local farm surface roughness, and topographical influences are considered.

The parametric approach allows consideration of the full range venting configurations and potential vapor concentration over the range of meteorological conditions at the Hanford Site. More detailed analyses that consider specific operations and/or contaminants have been conducted at the Hanford Site (see for example, Stam and Crummal 2002) and for other sites (see for example Hunter 2004a, b, c). The parametric analysis reported below allows the estimation of plume properties for specific operations and/or contaminants such as reported in these studies.

The concentrations and processes in the Hanford Site tank headspaces have been the topic of considerable study (Stock and Huckaby 2000). Tracer studies have defined average tracer ventilation rates for passively ventilated tanks (Huckaby et al. 1997; Huckaby et al. 1998). Engineering studies have confirmed the ventilation rates for the double-shell tanks. Recently Faurote and Hocking (2004) conducted a study of the meteorological conditions for time periods with reported vapor incidents.

Two types of vents are associated with the Hanford underground tanks: near-surface and stack. The headspace air plumes from either of these can potentially be in a relatively undiluted concentration in the breathing zone around the releases. This situation is relatively obvious for the near-surface releases only if there is significant plume rise could these plumes not be in the breathing zone. For stack releases, the plume can dip down into the breathing zone for short time periods as part of atmospheric turbulence. Such an occurrence will happen more often if the stack is located upwind or downwind of roughness elements of the same size as the stack (i.e., building wake influences). Also certain times of day will be more amenable to such incursions - such as in the early morning hours in the summer when the nocturnal inversion is "burned off" by isolation. Such incursions may be less likely if there is significant plume rise for the stack releases.

As the air from the tank headspace is released, there is a potential for workers in the immediate area to be exposed to the vapor concentrations in that air. The time scale for atmospheric dispersion of the released vapors is the key factor in considering the potential exposures to tank vapors. Very near the source, the travel time of the release will be very short. Rapid concentration fluctuations (i.e., occurring within seconds) with peaks approaching undiluted concentrations will be observed as the plume/person moves in and out of the plume. At extended distances the time scale for dispersion will be greater. Slow concentration fluctuations will occur at normally much more diluted concentration levels. The former refers to the near-field instantaneous concentrations and the latter to average concentrations for time periods of 15 minutes or greater. 
This analysis addresses the near-field instantaneous air concentrations and their frequency of occurrence. The characterization of these peak concentrations is important in understanding the frequency and implications of short-duration exposure to such short-duration concentrations. The analysis also addresses the expected heights of the plumes of headspace air to assess the potential for worker exposures.

The relative locations of a worker relative to venting locations, combined with the ambient winds, determine what portions of a plume a worker is exposed. The concentrations in that plume will be a function of how much dilution has occurred after the material is released to the atmosphere. The two major factors in determining the amount of dilution is proximity to the venting location and the ambient turbulence conditions. The farther the plume travels, the greater the dilution.

For dispersion modeling, ambient turbulence conditions are grouped into "Stability Classes," which represent different rates of ambient dilution. When the vertical thermal structure of air near the surface is unstable because of heating at the surface (i.e., low-wind, sunny daytime conditions), the conditions are called "Unstable" and divided into three classes with progressively smaller dilution rates (A, B, and C). When the vertical thermal structure of air near the surface is stable because of nocturnal cooling at the surface, the conditions are called "Stable" and divided into three classes with progressively smaller dilution rates $(\mathrm{E}, \mathrm{F}$, and $\mathrm{G})$. Under transition conditions when the thermal structure is neutral, the class is "NeutraP' with a dilution rate (D) between the unstable and stable rates. Conditions with higher winds tend to have dilution rates closer to the $\mathrm{D}$ class.

At issue are the maximum concentrations of tank vapors as a function of distance from the source under various meteorological conditions, which meteorological conditions increase the risk of worker exposures, and whether any known sources represent currently unrecognized risks.

The emphasis in this analysis is to understand the magnitudes and mechanics of potential exposures to people working in the immediate area downwind of the tank vents. Short-duration peak concentrations involve exposure to relatively undiluted air from the tank. Such exposures are limited to being quite localized as a result of the very small volumes of air. Average exposures will be lower, reflecting the time in the plume and the effect of ambient atmospheric turbulence.

The objective of this analysis is to provide information relative to the variation of concentrations during different meteorological conditions. The peak and average concentrations as well as the plume rise are investigated for each type of tank ventilation configuration. This approach provides information on what can happen to the vented air during different ambient conditions. It is anticipated that this information will be used in evaluating operational procedures. 


\subsection{Near-Field Air Concentrations}

A tank farm worker operates in the breathing space over the tanks. That person may be very close to a venting location - or at some close distance including locations in adjacent tank farms. These distances are referred to here as near-field concentrations.

The initial release characteristics such as height, area, velocity, temperature, vent orientation, and wake influences will determine the initial dilution and movement of the vented air. Three configurations for tank releases are considered: 1) near-ground passive vents, 2) forced-air stacks, and 3) passive stacks. The 242-A evaporator stack is also considered.

The near-field results are expressed as concentrations normalized to headspace concentrations. The air concentrations of a specific vapor may be obtained by multiplying by the headspace concentration of that vapor.

The near-field concentrations are models that consider the initial plume characteristics and ambient atmospheric dilution. Although relatively little is specifically known about the exact nature of transient releases from the tanks, it is possible to quantify the possible range of characteristics.

\subsection{Tank Characterization}

The tanks at the Hanford Site include single-shell tanks that are mainly passively vented and double-shell tanks that are have forced venting through stacks. The near-field concentrations will be mainly controlled by a combination of release characteristic $s$ and local surface roughness elements located at near-field distances. As a result the near-field concentrations at the numerous types and locations of tanks can be characterized by conducting computations over combinations of ranges of the pertinent conditions.

The following assumptions are made in this modeling:

- The initial concentrations at the venting locations will the same as measured in the headspace.

- Past tracer studies provide a range of potential average emission rates.

- The short-term emission rates are driven by some combination of pressure, wind, and temperature influences.

- The exit temperature from a passively vented tank with a near-surface release vent can be represented by the temperature of the headspace. The exit temperature of a passively vented tank with a stack vent is essentially equal to ambient temperature.

- The exit temperatures from forced-air stacks is largely controlled by the air-handling systems and show a seasonal variation. Other release characteristics are mainly defined by design specifications. 


\subsection{Initial Concentrations}

During routine emissions, the concentrations in the tank headspaces are assumed to represent the maximum concentrations that will be released and can potentially occur in the environment. Pockets of air in the plume of headspace air can occur that have not had any significant dilution, deposition, or reaction.

Material from the headspace may be held for some time before it is released to the air. Such material may be released from electrical panels, etc. Using typical volumes and assuming a short duration release (i.e., five or six seconds) indicates that such a release is on the upper end of the passive emission rates, but much less than the forced-air emission rates of the tanks. Thus the higher near-surface passive vent rate results are applicable to these potential short-duration releases of headspace concentrations.

\subsection{Average Tank Emission Rates}

Tracer studies in the 1996-1998 timeframe provide field measurements of tank ventilation rates over a time period of one week to more than a month (Huckaby et al. 1997, Huckaby et al. 1998). Figure 1 shows the range of ventilation rates observed in those studies. The rates shown in Figure 1 include

Observed Ventilation Rates

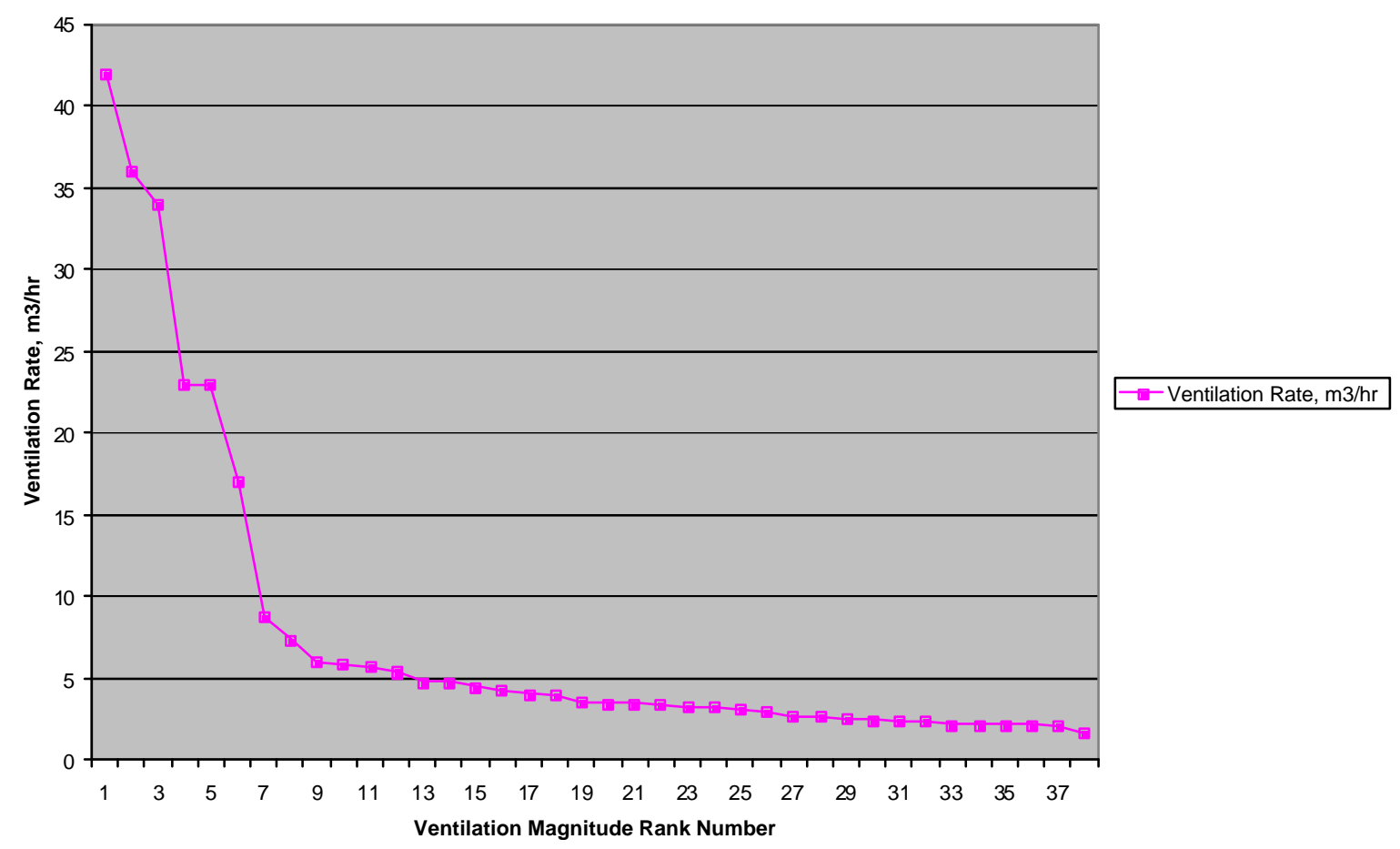

Figure 1. Range of Tank Ventilation Rates from 1996-1998 Tracer Studies 
ventilation both to the ambient atmosphere as well as to other tanks via underground pipes. The results are external ventilation for tanks not connected to other tanks. For connected tanks the ventilation rates are external ventilation rates for the time periods where the tracer had come in near equilibrium with any joined tanks. For others, it is clear that air exchange between tanks may be the dominant factor seen in the tracer tests. In this effort the conservative assumption is made that these average ventilation rates all represent potential average tank emission rates. This assumption may overestimate the actual range of emission rates but is a worst-case assumption in terms of understanding the concentrations to which a worker may potentially be exposed.

\subsection{Models}

Plume rise is computed using the algorithms documented for the computer code, Industrial Source Complex (ISC) developed by the U.S. Environmental Protection Agency (EPA). Plume rise was also computed using the published routine in another EPA model, INPUFF. The results from these two models were very nearly identical and only the ISC results are reported here.

Average concentration is computed using a Gaussian plume model and the EPA-recommended dispersion curves for rural (i.e., non-urban) settings (Briggs 1973). The equation for the centerline average concentration for a continuous point with a reflecting surface is the following:

$$
C(x, z) / Q=1 /\left[F^{\prime}+2 \pi \sigma_{y} \sigma_{z} \bar{u}\right]\left[\exp \left\{-(z-h)^{2} /\left(2 \sigma_{z}{ }^{2}\right\}+\exp \left\{(z+h)^{2} /\left(2 \sigma_{z}{ }^{2}\right)\right\}\right]\right.
$$

$$
\text { where } \begin{aligned}
\mathrm{C} & =\text { air concentration, } \mathrm{g} / \mathrm{m}^{3} \\
\mathrm{Q} & =\text { the release rate, } \mathrm{g} / \mathrm{s} \\
\mathrm{X} & =\text { the downwind distance, } \mathrm{m} \\
\mathrm{Z} & =\text { the height of computed concentration, } \mathrm{m} \\
\mathrm{H} & =\text { the height of the center of the plume, } \mathrm{m} \\
\mathrm{F}^{\prime} & =\text { the flow rate from the source, } \mathrm{m}^{3} / \mathrm{s} \\
\mathrm{s}_{\mathrm{y}} & =\text { the horizontal diffusion coefficient, } \mathrm{m} \\
\mathrm{s}_{\mathrm{z}} & =\text { the vertical diffusion coefficient, } \mathrm{m}
\end{aligned}
$$

Equation 1 is similar to the Gaussian plume equation used. Equation 1 uses the approach to account for the initial plume dilution and has exponential terms for computing concentrations for elevated releases. The equation assumes complete reflection of the material at the ground and no loss of material to deposition or chemical reactions. The equation is applicable for estimates of average concentrations for a continuous release for time periods as short as 15 minutes but is normally applied to an hour.

The initial wake dilution from the vent, stack, or other local structures is accounted for by replacing $\left(\mathrm{s}_{\mathrm{y}} \mathrm{s}_{\mathrm{z}}\right)$ with $\left[\left(\mathrm{s}_{\mathrm{y}} \mathrm{s}_{\mathrm{z}}\right)^{2}+\mathrm{A}^{2}\right]^{0.5}$ in Equation 1. A is a characteristic wake area, $\mathrm{m}^{2}$, which is computed based on the area of the release and takes effect over a distance on the order of the effective radius of that area.

The concentration results are reported as the fractional concentration remaining of the initial concentration that comes out of the vent or stack. The procedure is to normalize the outputs by dividing the value obtained by Equation 1 by the initial vented concentration. 


\subsection{Peak and Average Concentrations}

The atmospheric transport and dispersion diffusion curves describe processes at distances of $100 \mathrm{~m}$ or greater from the source. At locations near the release, the dilution rates are strongly controlled by the release characteristics and local surface conditions.

The Gaussian dispersion model provides average concentration values as function of downwind distance. These average concentrations represent the average of instantaneous concentrations over the averaging period. Very close to the release, this will involve averaging widely varying concentrations. Moving downwind, atmospheric turbulence will mix the released air with ambient air such that the larger downwind plumes will be progressively more uniform in terms of short time-scale fluctuations.

Air dispersion models are used to address the near-field concentrations by including detailed algorithms for initial dilution influences. For ambient atmospheric turbulence the standard dispersion curves are extrapolated to the near-field distances assuming no initial dispersion. Terms are then added to the dispersion rates that account for near-field dilution influences (release characteristic, stack wake, building wake, local roughness, etc.). This approach is useful to understand the average near-field exposures.

The issue of concentration variability and especially short-duration peaks needs to be addressed to better understand the potential for worker exposures to occasionally higher concentrations. That is, the computed average worker exposures may be well within acceptable exposure limits - but a worker may smell or otherwise react to higher short-term peak concentrations.

The definition of peak concentration depends on the time period over which it is defined. In the tank farms numerous short-duration sensory events (Faurote and Hocking 2004) have been reported. Many of these involve only several seconds duration, which is a shorter time period that has been considered in field studies of peak concentrations at the Hanford Site. The ${ }^{85} \mathrm{Kr}$ tracer tests at the Hanford site used a 28.4-second sampling period and provided a data set for characterizing peak-to-mean concentrations in a plumes from puff and short-time ( 15 minutes) releases (Ramsdell and Hinds 1969; Ramsdell 1971; Nickola et al. 1970). Ramsdell 1981 considers the frequency and magnitude of 5- to 10-minute peak concentrations of $\mathrm{NO}_{\mathrm{X}}$ based on monitoring data in the vicinity of the 200 East Area.

Peak concentration in this analysis is defined as the peak concentration that a worker may intake in a single or partial breath. This is very conservative approach in terms of defining the peak as the highest "instantaneous" concentration. The peak concentrations for one or two minutes will be much less that this single intake peak. The plume analysis reported here can be extended to peak concentrations for approximately one half-minute periods using the peak-to-mean empirical models derived by Ramsdell and Simonen (1997) and Ramsdell (1982).

At near-field distances, it is assumed that the maximum concentration can be no larger than the concentrations coming out of the vents (i.e., headspace concentrations). Near the vent, that initial concentration will be representative of the air concentration in the plume - with the computed average value representing mainly the spatial movement of that plume. Thus at near-field distances, it is reasonable to experience short-duration, undiluted pockets of that initial concentration. As the plume 
moves away from the vent, ambient turbulence will diffuse the plume and the average will be a combination of the spatial movement and the dilution of the air.

Given the slow ventilation rates of the tanks, the question of inhalation capacity arises. Average breathing rates vary between 0.8 and $1.5 \mathrm{~m}^{3} / \mathrm{hr}$ for healthy adults and construction workers, respectively (EPA 1997). The average measured tank venting rates (see Figure 1) start at rates essentially equal to a worker's average breathing rate and extend to rates that are 25 times or more greater than a worker breathing rate. Thus air vented from the tanks will have a volume that a worker could, if the plume is undiluted, get a breath of mostly vented air. However, the volume of the downwind breathing space is much larger than these volumes and the intake of relatively undiluted air downwind of a vent will be a limited-occurrence, short-duration event. Even if the worker's mouth is very near to the vent, the initial dilution in the wake of the vent will make it difficult to get a steady supply of undiluted air from the vent. Thus, the vented volume of headspace air is too small to be a significant source of the air inhaled by a worker.

The question of how far from the source will one still be likely to occasionally be exposed to the vented concentrations can only be defined in a probabilistic manner. We know there is a higher probability that those concentrations will be experienced near the source and a lower probability at extended distance. The manner that the probability will change with distance will be a direct function of the ambient atmospheric turbulence. The pockets of relatively undiluted air will tend to travel farther under nocturnal stable conditions and not as far under daytime unstable conditions.

To define the frequency of peak exposures as a function of distance, measures are needed as to how far pockets of undiluted air may travel in the plume. It is assumed that the distances where the initial plume concentrations has been reduced by one and two orders of magnitude represent distances that the undiluted pockets of air are unlikely to occur. This rule of thumb is based on the observation that peakto-mean ratio in near-field plumes have typical values between 2 and 6 with ratios of up to slightly more than an order of magnitude (Ramsdell 1971). These peak-to-mean ratios are based on about 1-halfminute average peak concentrations - a greater variability is expected for a severalsecond peak value. Although somewhat arbitrary in its selection, this definition of these distances over the possible range of surface and metrological conditions will provide valuable insight into relative changes in the potential for exposure to high short-duration concentrations for different tank vent types.

The parameterization of atmos pheric turbulence in Equation 1 does not apply under calm conditions. Observations show that diffusion continues to occur even under calm conditions and the air is always moving, albeit very slowly. The limiting case of calm wind condition is represented here by using a nominal wind speed of $1^{\circ} \mathrm{m} / \mathrm{s}$.

The probability of encountering the plume can be roughly quantified. Assuming both the plume and worker are moving around in the breathing space, the average width of a plume at a given distance divided by the width of the working area will provide an indication of how likely a worker is to be located in the plume. For the probability of exposure to a relatively undiluted plume, the initial width of the plume is used to characterize the maximum width of an undiluted pocket of concentration. That is, 


$$
\begin{aligned}
& \mathrm{w}_{\mathrm{a}}=\text { width of average plume (taken as equal to } 2 \mathrm{~s}_{\mathrm{y}} \text { ) } \\
& \mathrm{w}_{\mathrm{p}}=\text { width of undiluted plume (taken equal to a initial dispersion length) } \\
& \mathrm{w}_{\mathrm{arc}}=\text { width of a } 90 \text { degree arc at distance } \mathrm{x}
\end{aligned}
$$

The average and peak fractions, $\mathrm{f}_{\mathrm{a}}$ and $\mathrm{f}_{\mathrm{p}}$, for the worker located in a 90 degree arc downwind of the vent is computed using: $\mathrm{f}_{\mathrm{a}}=\mathrm{w}_{\mathrm{a}} / \mathrm{w}_{\text {arc and }} \mathrm{f}_{\mathrm{p}}=\mathrm{w}_{\mathrm{I}} / \mathrm{w}_{\text {arc }}$.

This relationship is useful for looking at specific tank vents. It will be informative for understanding the releases from tanks in general to take a more generic approach based on assuming typical work areas and computing the fractions for a worst-case configuration of a vent and the working area.

\subsection{Results}

\subsubsection{Plume Rise}

The potential for the vented air plume from the tanks to rise from buoyancy or momentum processes is considered. The total height of the plume rise plus the release height is referred to as the effective plume height. The plume rise will depend on the exit area, area, temperature, speed, and direction as well as local vertical structure of atmospheric temperature, turbulence, and wind speed.

The air from the tank enters the atmosphere at some height over the local surface. Surface releases start within the breathing zone. Stack releases occur above the breathing zone but have the potential of intersecting ground level if surrounded by terrain that is higher than the effective plume height. Also wake effects from the stack itself or from adjacent buildings may result in an effective plume height that is lower than the release height.

The plume rise model described in the Environmental Protection Agency's Industrial Source (ISC) Models is used. As with the temperature computation, the turbulence is characterized by stability classes. The exit parameters for the various tank configurations are considered for the range of possible atmospheric conditions to define the range of possible plume rise realizations.

The stack releases are all at a sufficient height that the release of air from the tanks will be above the breathing zone. To assess if these plumes are potentially important in the breathing zone, the concentrations in this elevated plume need to be computed. Then it needs to be determined if there is any potential of that plume impacting the breathing zone. Near-surface exposures are very unlikely if the released air rises rapidly. If, on the other hand, there is little or no plume rise, then it is reasonable to assume that atmospheric turbulence will carry the plume occasionally into the breathing zone. The distance out to the point where the average plume diffuses down to the surface (referred to as the plume touchdown distance) will be important in assessing the potential for higher concentrations occurring in the breathing zone. As with the surface release, the maximum peak concentration is limited by, and likely represented by, the peak concentrations coming out of the stack.

Plume rise depends on the exit area, vertical speed, and temperature as well as atmospheric temperature, turbulence, and wind speed. Potential plume rise is computed for representative ranges of the controlling parameters to evaluate if, and under what conditions, significant plume rise may occur. A range of 
potential exit flow conditions is considered for the passively vented near-surface releases. Based on the tracer studies of ventilation rate values of $1 \mathrm{~m}^{3} / \mathrm{hr}$ (well-sealed tank), $10 \mathrm{~m}^{3} / \mathrm{hr}$ (moderately venting tank) and $100 \mathrm{~m}^{3} / \mathrm{hr}$ (upper range of passive venting rates). The exit flow characteristics of the stacks associated with tanks used in the plume rise modeling are listed in Tables 1 through 3 . The exit velocities computed from the data in Table 1 are comparable to the stack velocities measured for a number of the tanks in RPP-982 (Stam and Crummal 2002) with the measured values tending to be about a factor of two lower than the computed values. The exit temperatures measured in RPP-982 are also consistent with the assumed exit temperatures for the tanks.

A considerable difference exists between the two tanks with measured exit temperatures. As is expected, the observed exit temperatures are greater in the summer than winter. The important parameter in plume rise modeling is the difference between the exit and ambient air temperatures. If the exit air is equal to, or cooler than the ambient air, then the tendency will be for the plume height not to rise. Also the greater the upward exit velocity, the greater the potential plume rise. Downward exit velocities tend to result in plume fall rather than rise.

The exit temperatures reported for tank stack operations conf igurations listed in Table 2 indicates two different types of tank ventilation systems. Typical values of exit temperatures, using the data in Table 2 are listed in Table 3. The typical ambient temperatures from the Hanford Meteorological Station (Hoitink et al.

Table 1. Tank and 242A Evaporator Stack/Vent Exit Flow Parameters

\begin{tabular}{|c|c|c|c|c|c|c|c|}
\hline \multirow[b]{2}{*}{ Name of Vent/Stack } & \multicolumn{2}{|c|}{ Stack Height } & \multicolumn{2}{|c|}{ Diameter } & \multicolumn{2}{|c|}{ Flow Rate } & \multirow[b]{2}{*}{ Source } \\
\hline & $\mathbf{f t}$ & $\mathbf{M}$ & in. & $\mathbf{m}$ & scfm & $\mathrm{m} 3 / \mathrm{s}$ & \\
\hline AN Farm Existing Vent & 15.5 & 4.7 & 10 & 0.254 & 600 & 0.283 & RPP-19512, Rev. $0^{(\mathrm{a})}$ \\
\hline AN Farm W-314 (low flow) & 28 & 8.5 & 10 & 0.254 & 1000 & 0.471 & RPP-19512, Rev. $0^{(\text {a) }}$ \\
\hline AN Farm W-314 (high flow) & 28 & 8.5 & 10 & 0.254 & 2000 & 0.943 & RPP-19512, Rev. $0^{(\text {a) }}$ \\
\hline AP Farm W/ Extension (low flow) & $19^{\prime} 7^{\prime \prime}$ & 6.0 & 6 & 0.152 & 800 & 0.377 & (b) \\
\hline AP Farm W/ Extension (high flow) & $19^{\prime} 7^{\prime \prime}$ & 6.0 & 6 & 0.152 & 1200 & 0.566 & (b) \\
\hline AW Farm Existing Vent & 15.8 & 4.8 & 10 & 0.254 & 1000 & 0.471 & RPP-19512, Rev. $0^{(\text {a) }}$ \\
\hline AW Farm W-314 (low flow) & 28 & 8.5 & 10 & 0.254 & 1000 & 0.471 & RPP-19512, Rev. $0^{(\mathrm{a})}$ \\
\hline AW Farm W-314 (high flow) & 28 & 8.5 & 10 & 0.254 & 2000 & 0.943 & RPP-19512, Rev. $0^{(\mathrm{a})}$ \\
\hline AY/AZ Existing Vent & 55 & 16.7 & 10.4 & 0.264 & 1000 & 0.471 & $3-\mathrm{VB}-155 \mathrm{O}^{(\mathrm{c})}$ \\
\hline SY Farm Existing Vent & 17.5 & 5.3 & 6 & 0.152 & 800 & 0.377 & RPP-19512, Rev. 0 ${ }^{(a)}$ \\
\hline 242A Evaporator & 62 & 18.9 & 8 & 0.203 & 700 & 0.330 & $3-V B P-657 B^{(c)}$ \\
\hline \multicolumn{8}{|c|}{$\begin{array}{l}\text { (a) Stam and Crummal (2002). } \\
\text { (b) Personal communication from Curty Lewis, CH2M HILL June 2004. } \\
\text { (c) Personal communication from CH2M HILL Hanford Group, Inc.: “242-A Vessel Vent Exhauster Stack 296-A-22 Air Flow } \\
\text { Test Data Sheets” used in conjunction with procedure 3-VBP-657 “242-A Evaporator Stacks Air Flow Test.” }\end{array}$} \\
\hline
\end{tabular}


Table 2. Summary of Observed Tank Vent/Stack Exit Temperatures

\begin{tabular}{|c|c|c|c|c|c|c|c|c|c|}
\hline \multirow[b]{3}{*}{ Entry Type } & \multirow[b]{3}{*}{ Facility/Case } & \multicolumn{4}{|c|}{$\begin{array}{c}\text { Typical Values of Exit Gas } \\
\text { Temperature as reported in } \\
\text { TWINS }\end{array}$} & \multirow{2}{*}{\multicolumn{2}{|c|}{$\begin{array}{c}\text { Exit Gas } \\
\text { Temperature } \\
\text { Design } \\
\text { Computation, } \\
\text { RPP-9782 } \\
\text { Attachment } 1 \\
\text { (November) }\end{array}$}} & \multirow{2}{*}{\multicolumn{2}{|c|}{$\begin{array}{c}\text { Air Heating } \\
\text { Temperature } \\
\text { Increment, } \\
\text { RPP-9782 } \\
\text { Section } 3 \\
\text { Stated Design }\end{array}$}} \\
\hline & & \multicolumn{2}{|c|}{ (Winter) } & \multicolumn{2}{|c|}{ (Summer) } & & & & \\
\hline & & ${ }^{\circ} \mathbf{F}$ & ${ }^{\circ} \mathbf{C}$ & ${ }^{\circ} \mathbf{F}$ & ${ }^{\circ} \mathbf{C}$ & ${ }^{\circ} \mathbf{F}$ & ${ }^{\circ} \mathbf{C}$ & ${ }^{\circ} \mathbf{F}$ & ${ }^{\circ} \mathbf{C}$ \\
\hline \multirow[t]{7}{*}{ Reported Values } & AN Farm Existing Vent & & & & & 72 & 22.2 & 30 & -1.1 \\
\hline & AN Farm W-314 & & & & & 72 & 22.2 & 30 & -1.1 \\
\hline & AP Farm W/ Extension & 105 & 40.6 & 130 & 54.4 & 72 & 22.2 & \begin{tabular}{|c|} 
Maximum \\
Temp. \\
Control
\end{tabular} & \\
\hline & AW Farm Existing Vent & & & & & 72 & 22.2 & 30 & -1.1 \\
\hline & AW Farm W-314 & & & & & 72 & 22.2 & 30 & -1.1 \\
\hline & AY/AZ Existing Vent & 70 & 21.1 & 82 & 27.8 & & & & \\
\hline & SY Farm Existing Vent & & & & & 72 & 22.2 & 20 & -6.7 \\
\hline
\end{tabular}

Table 3. Summary of Tank Stack Exit Temperatures

\begin{tabular}{||l|c|c|c|c||}
\hline \multirow{2}{*}{} & \multicolumn{3}{|c||}{ Typical Temperatures } \\
\cline { 2 - 5 } & \multicolumn{2}{|c||}{ Winter } & \multicolumn{3}{|c||}{ Summer } \\
\cline { 2 - 5 } & ${ }^{\circ} \mathbf{F}$ & ${ }^{\circ} \mathbf{C}$ & ${ }^{\circ} \mathbf{F}$ \\
\hline Exit Vent Temperature, Low & 72 & 22.2 & 82 & 27.8 \\
\hline Exit Vent Temperature, High & 105 & 40.6 & 130 & 54.4 \\
\hline Ambient Air Temperature, Low & 26 & -3.3 & 90 & 32.2 \\
\hline Ambient Air Temperature, High & 40 & 4.4 & 55 & 12.8 \\
\hline Temperature Difference (Heating Threshold Controlled) & 79 & 43.9 & 40 & 22.2 \\
\hline Temperature Difference (Heating Delta Controlled) & 32 & 17.8 & 27 & 15.0 \\
\hline \hline
\end{tabular}

2004) allow computation of temperature differences between the exit and ambient air (Table 4). Two types of temperature differences occur: one which is typical of the 20 to $30^{\circ} \mathrm{F}$ heating of the exit air (Heating Delta Controlled) and the other that does not have a bound on the amount of heating (Heating Threshold Controlled). The tank with the former heating system does not show a large seasonal variation. The latter heating system does show such a variation. For the tanks with a "Heating Delta Controlled" system, the temperature difference settings are taken as representative of the values listed in Table 3 . The differences are $30^{\circ} \mathrm{F}$ for $\mathrm{AN}, \mathrm{AW}$, and Ay/AZ tank farms and $20^{\circ} \mathrm{F}$ for SY Tank Farm. The observed temperature difference values for summer and winter are used for the AP Tank Farm. The estimated 
Table 4. Tank Farm Stack Exit Air Temperatures

\begin{tabular}{||l|c|c|c|c|c|c||}
\hline \multirow{4}{*}{\multicolumn{1}{|c}{ Facility }} & \multicolumn{5}{c||}{ Plume and Air Temperature Difference } \\
\cline { 2 - 7 } & \multicolumn{2}{|c|}{ Winter } & \multicolumn{2}{c||}{ Summer } & \multicolumn{2}{c||}{ All Seasons } \\
\cline { 2 - 7 } & ${ }^{\circ} \mathbf{F}$ & ${ }^{\circ} \mathbf{C}$ & ${ }^{\circ} \mathbf{F}$ & ${ }^{\circ} \mathbf{C}$ & ${ }^{\circ} \mathbf{F}$ & ${ }^{\circ} \mathbf{C}$ \\
\hline AN Farm Existing Vent & & & & & 30 & 16.7 \\
\hline AN Farm W-314 & & & & & 30 & 16.7 \\
\hline AP Farm W/ Extension & 79 & 43.9 & 40 & 22.2 & & \\
\hline AW Farm Existing Vent & & & & & 30 & 16.7 \\
\hline AW Farm W-314 & & & & & 30 & 16.7 \\
\hline AY/AZ Existing Vent & & & & & 30 & 16.7 \\
\hline SY Farm Existing Vent & & & & & 20 & 11.1 \\
\hline 242A Evaporator & & & & & 0 & 0.0 \\
\hline
\end{tabular}

plume exit temperature for this stack is only slightly higher in the summer than the winter resulting in a more significant temperature differential with the ambient air in the winter. No data were found to indicate otherwise, so the Evaporator exit temperature is assumed not be significantly greater than ambient temperature (i.e., no credit is taken for buoyant plume rise).

Computations are made for combinations of atmospheric stability over a range of wind speeds. Wind speeds of $1 \mathrm{~m} / \mathrm{s}$ (low wind speed), $3.2 \mathrm{~m} / \mathrm{s}$ (average wind speed), $10 \mathrm{~m} / \mathrm{s}$ (typical high-wind speed), and $20 \mathrm{~m} / \mathrm{s}$ (extreme wind speed) are considered.

Figures 2 through 13 give the results of computation of plume rise. Each figure shows the results for different stability classes, A to G. Note that the stability classes are labeled only in Figure 2. Plume rise is computed for the range of exit flows and ambient wind speeds with those parameters defined in the $\mathrm{x}$ axis label For the forced-air stacks the sta ted exit flow is used. For the passively vented near-surface releases, a range of exit temperatures as well as ventilation rates are considered. For the passively vented stacks, the same range of ventilation rates as used for the near-surface vents. The results show that all vents and stacks do not have the potential to have significant plume rise with most cases having wake effect that lowers the plume. The wake effects of the release structure lower the plume height and cause the initial dilution of the plume. None of the few cases with an increase in plume height represents a significant change in the plume height. 


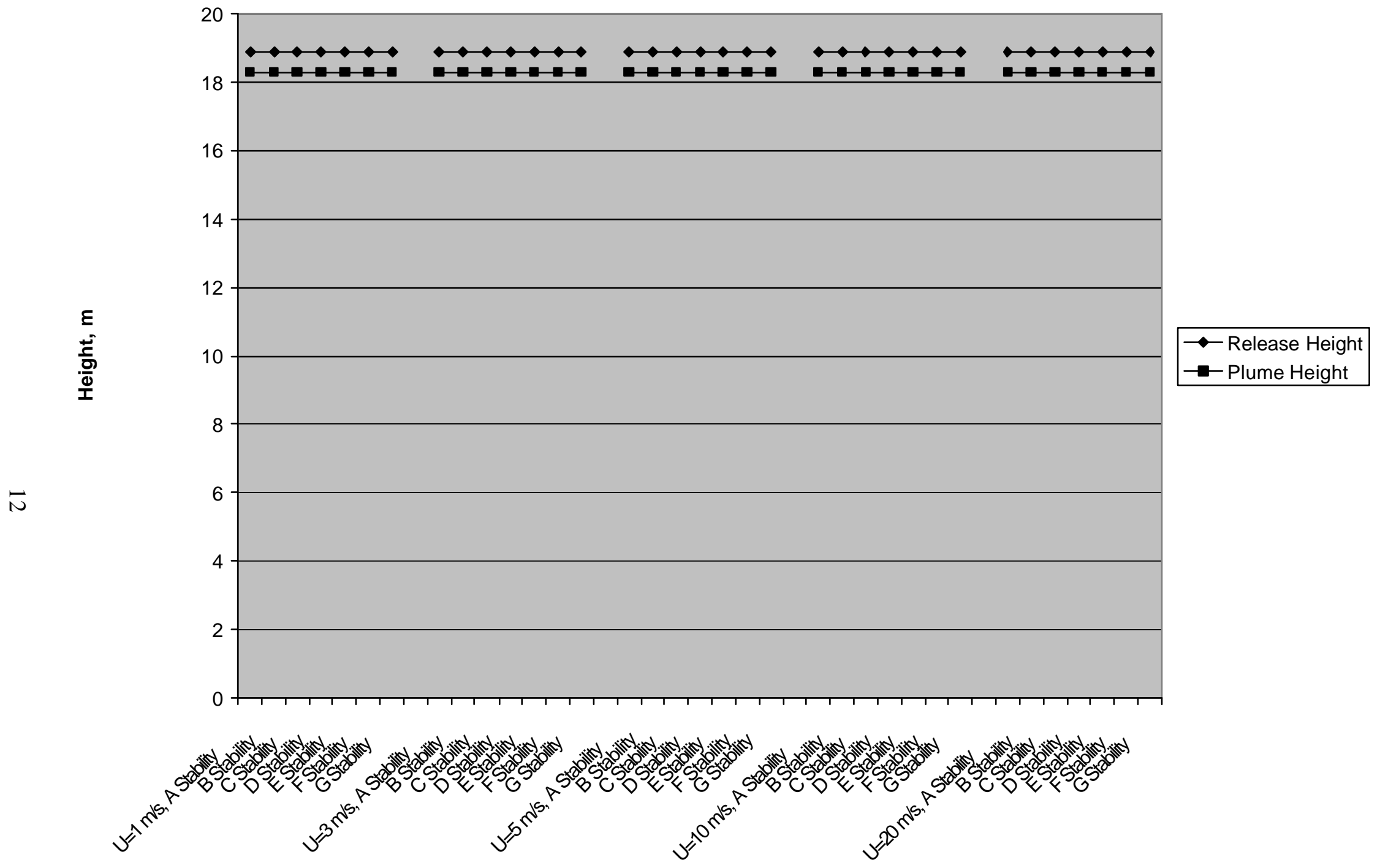

Figure 2. Plume Rise for 242A Evaporator Stack 


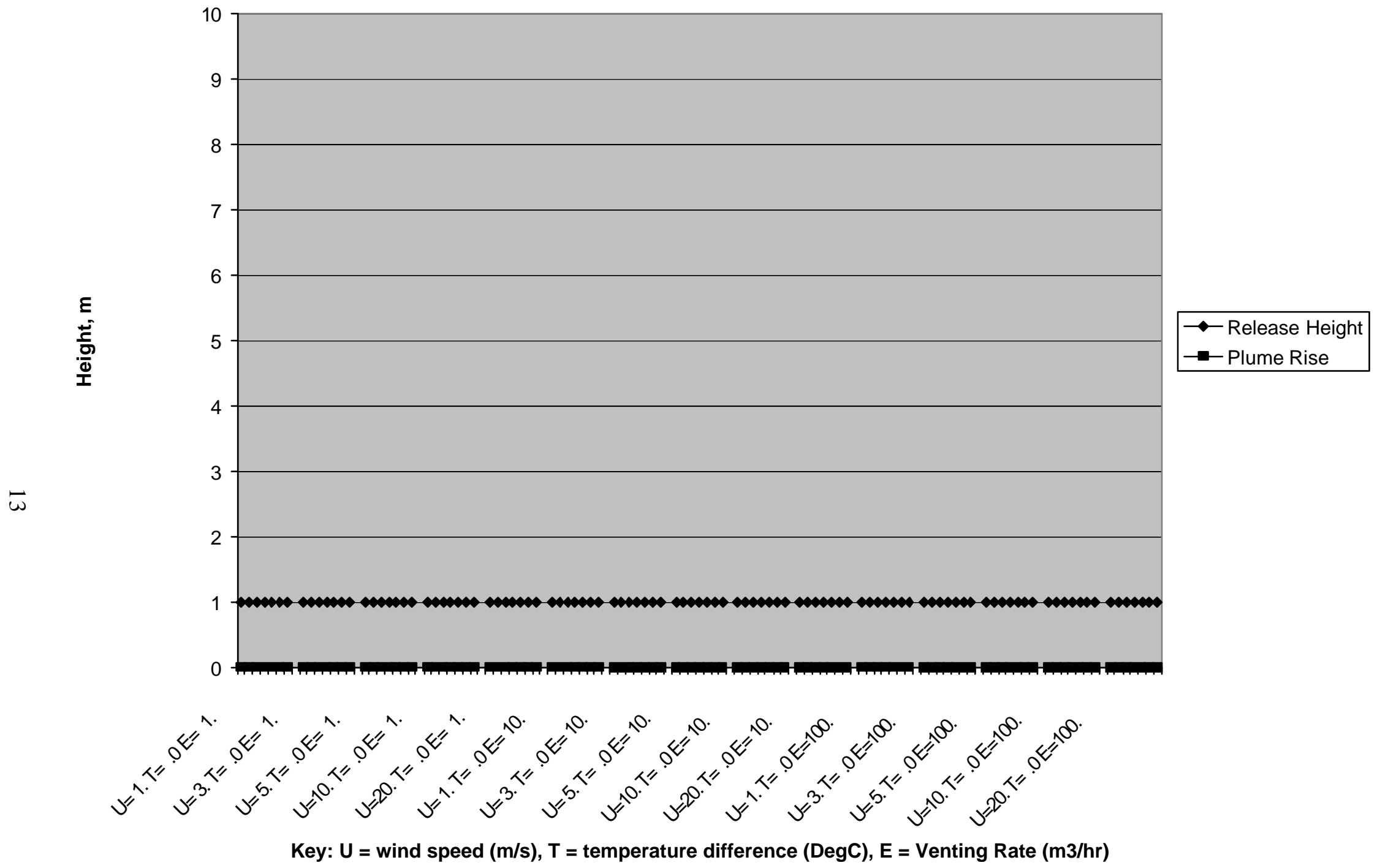

Figure 3. Computed Plume Rise for Near-Surface Box Vents with No Buoyancy 


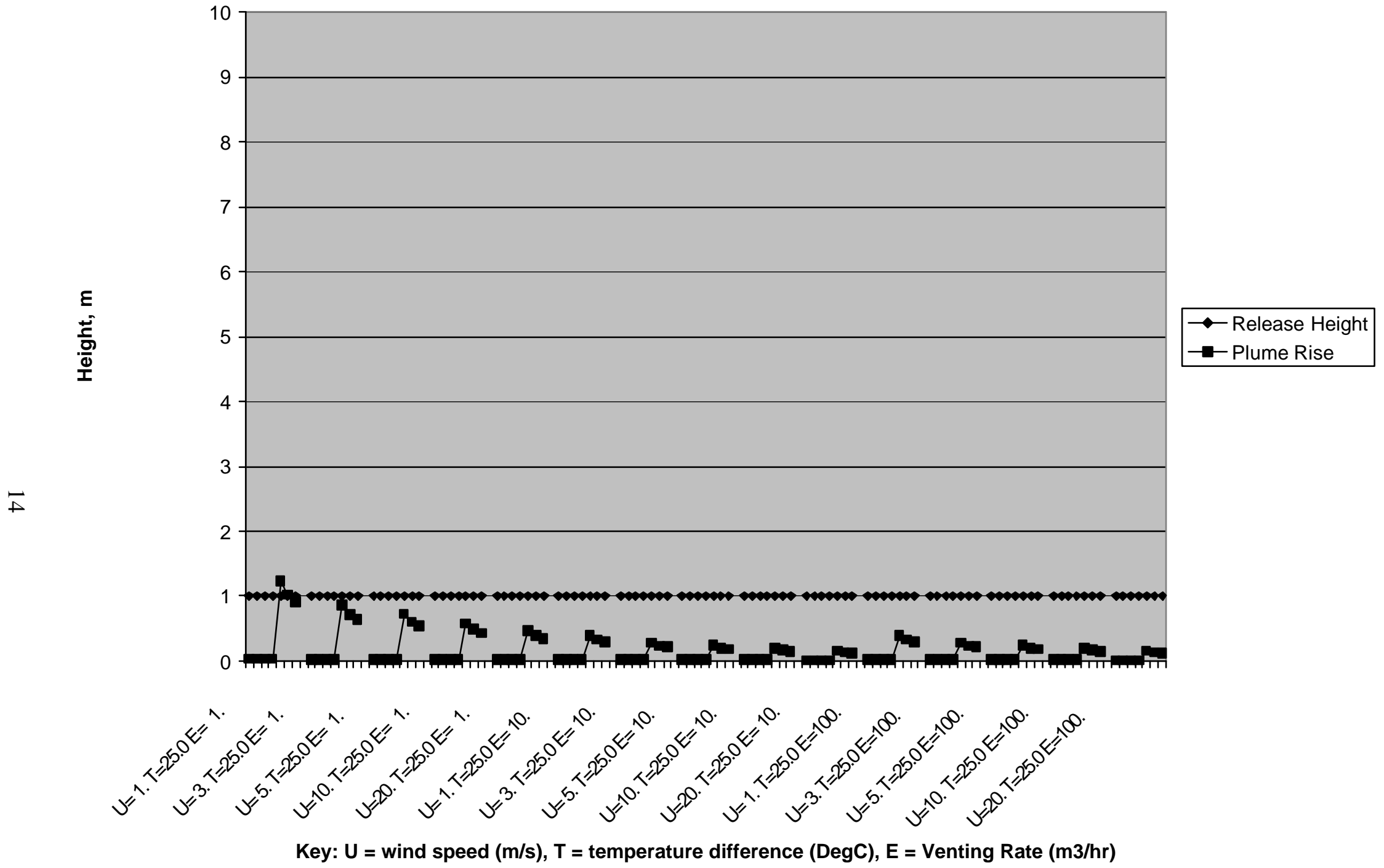

Figure 4. Computed Plume Rise for Near-Surface Box Vents with Moderate Buoyancy 


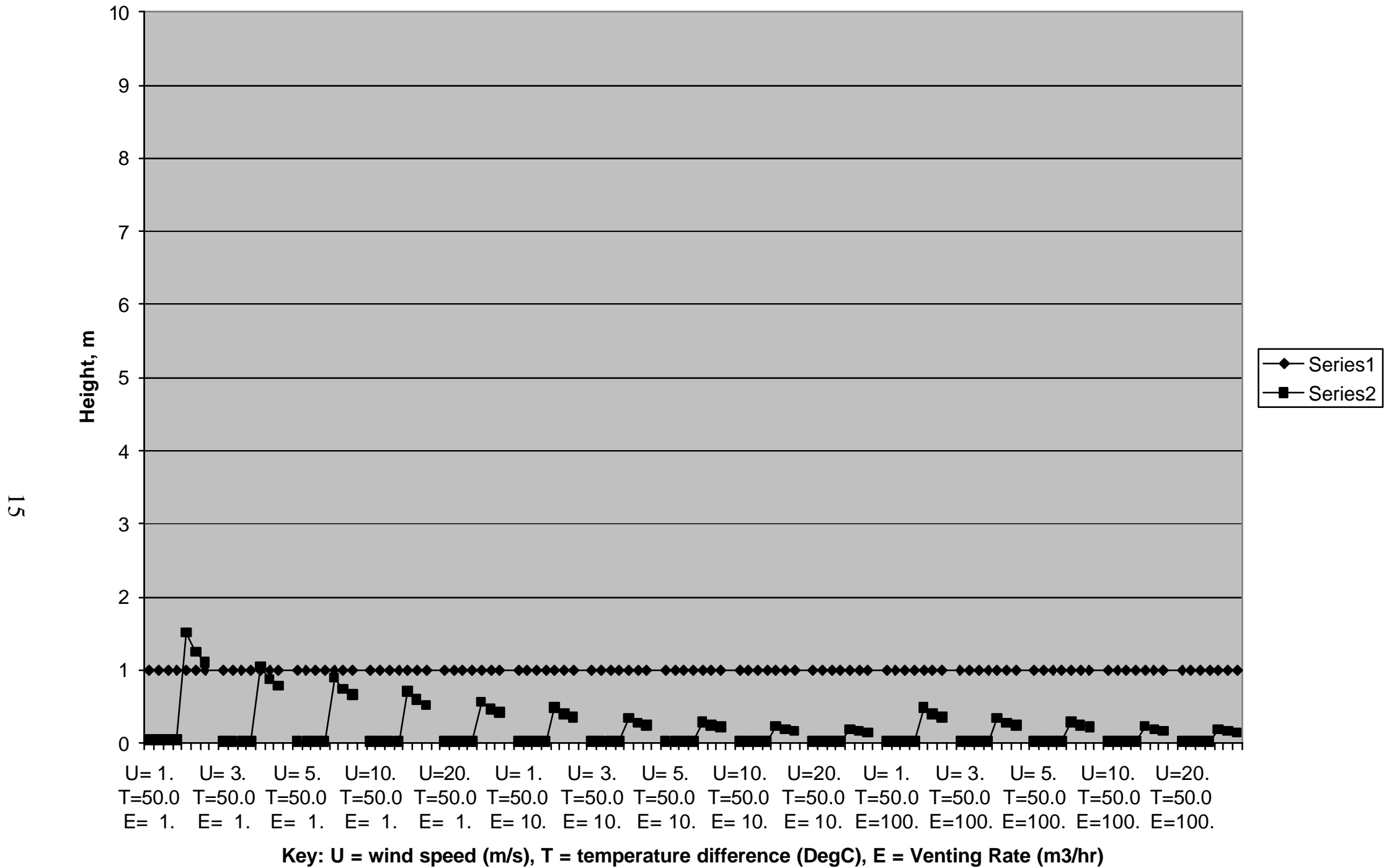

Figure 5. Computed Plume Rise for Near-Surface Box Vents with Maximum Buoyancy 


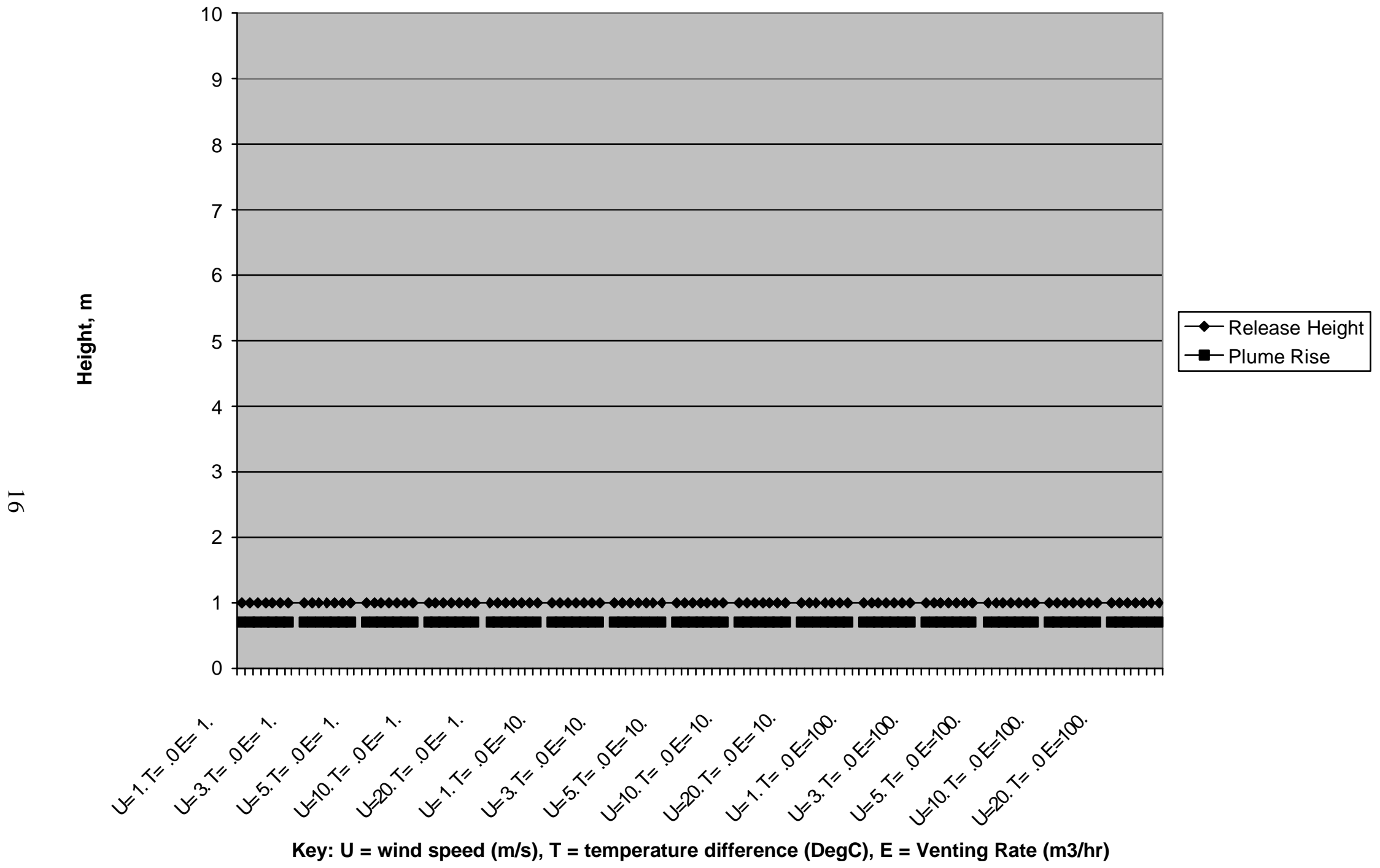

Figure 6. Computed Plume Rise for Near-Surface Pipe Vents with No Buoyancy 


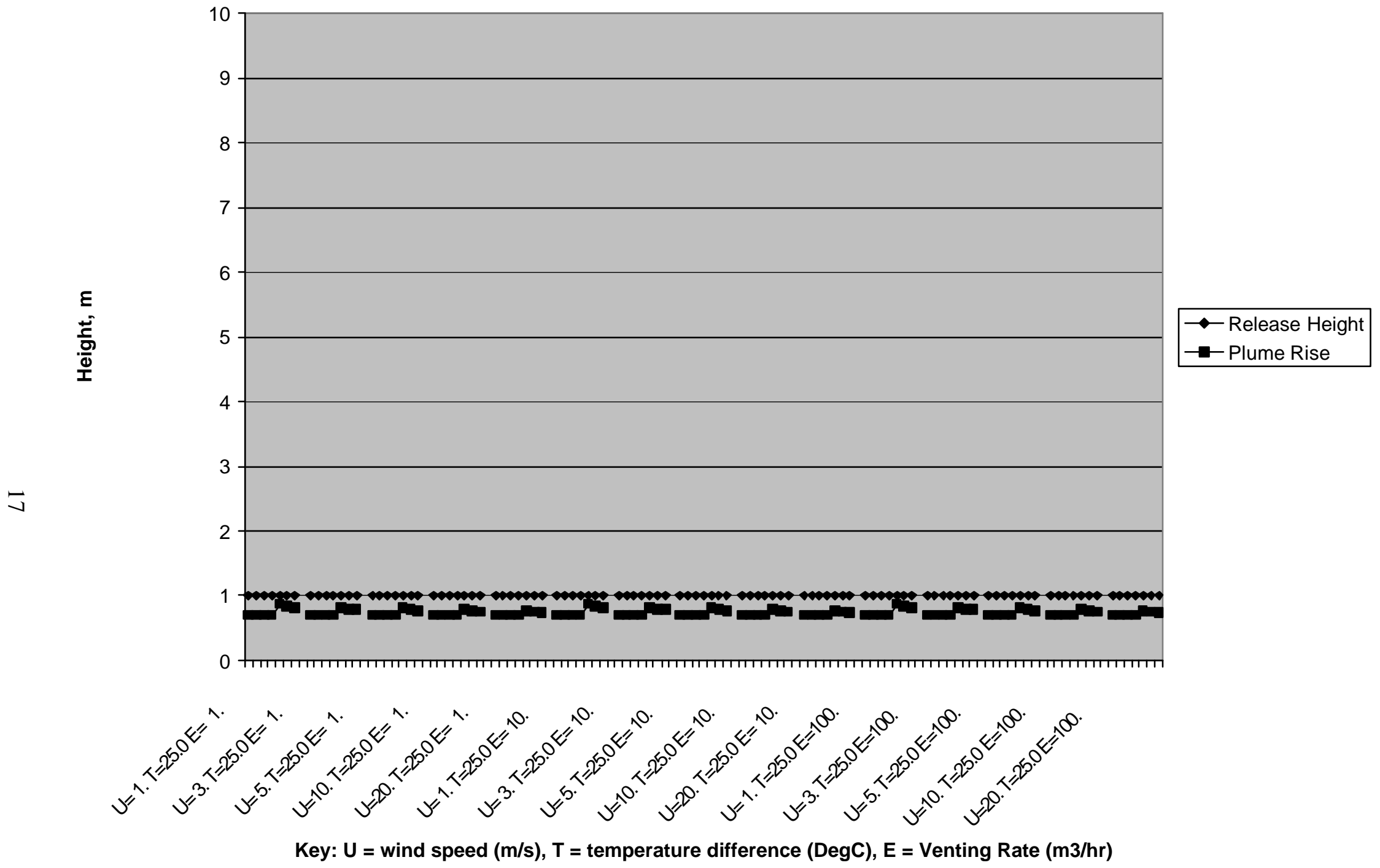

Figure 7. Computed Plume Rise for Near-Surface Pipe Vents with Moderate Buoyancy 


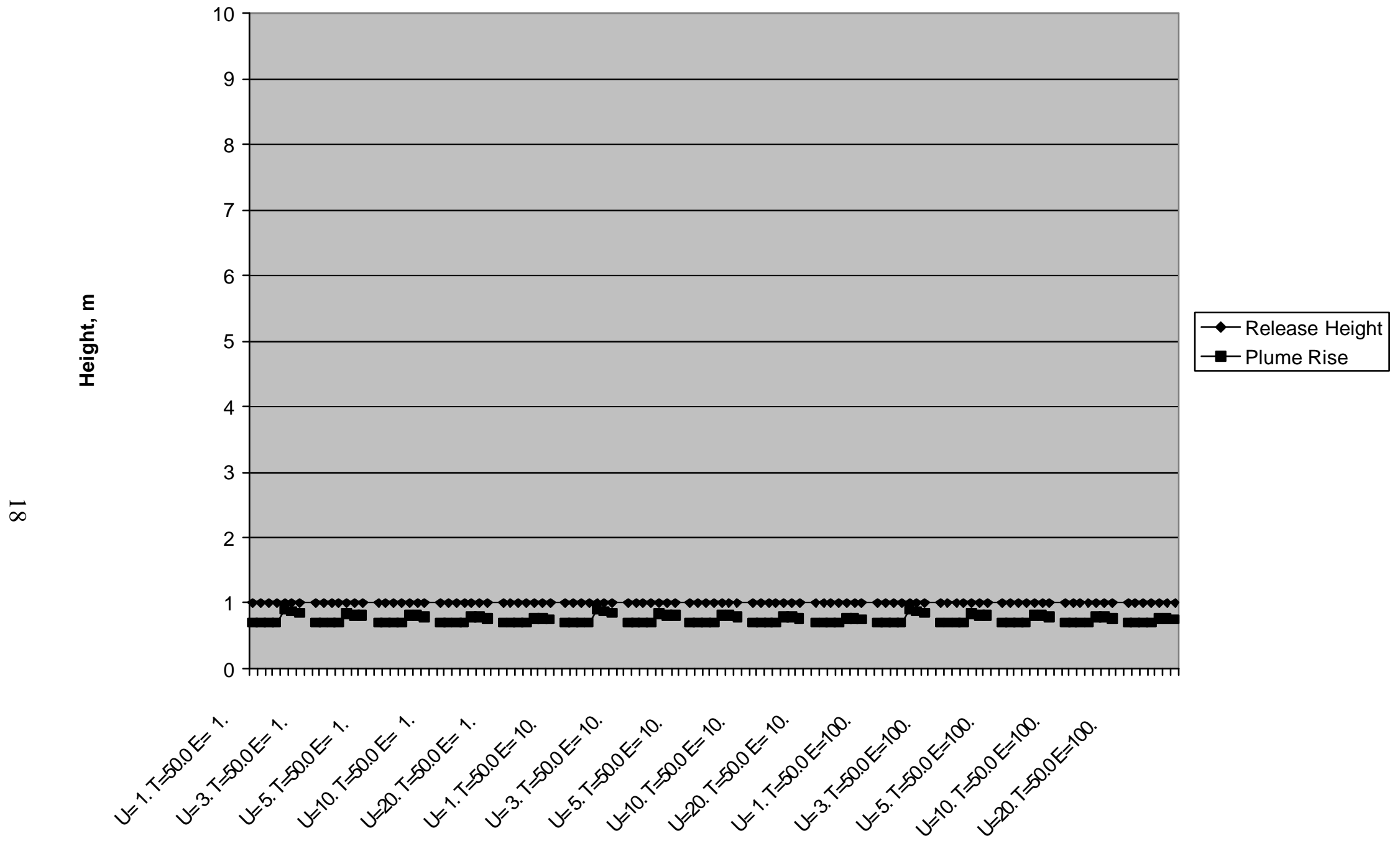

Key: $\mathrm{U}=$ wind speed $(\mathrm{m} / \mathrm{s}), \mathrm{T}=$ temperature difference $(\operatorname{DegC}), \mathrm{E}=$ Venting Rate $(\mathrm{m} 3 / \mathrm{hr})$

Figure 8. Computed Plume Rise for Near-Surface Pipe Vents with Maximum Buoyancy 


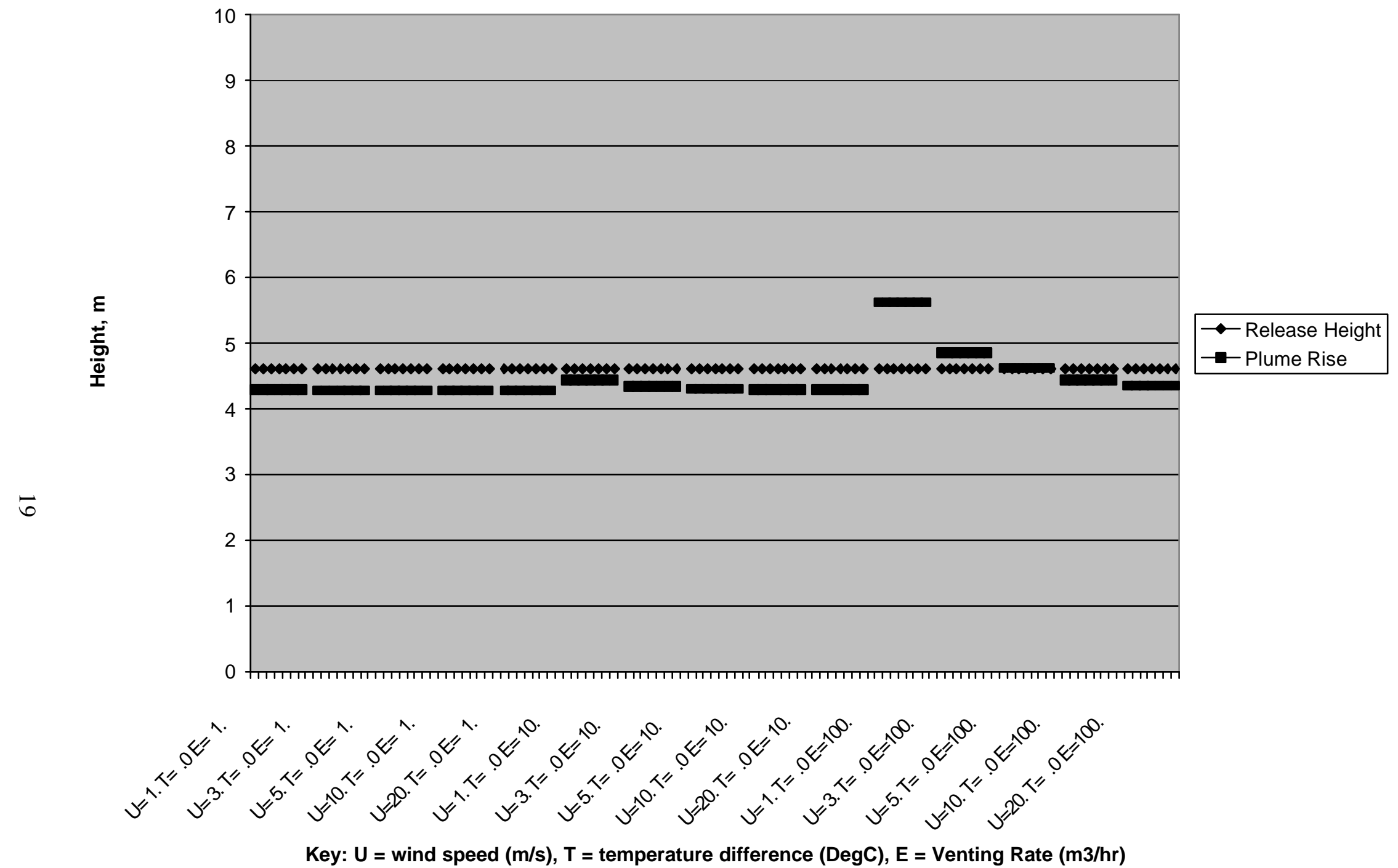

Figure 9. Computed Plume Rise for Passively Vented Stacks 


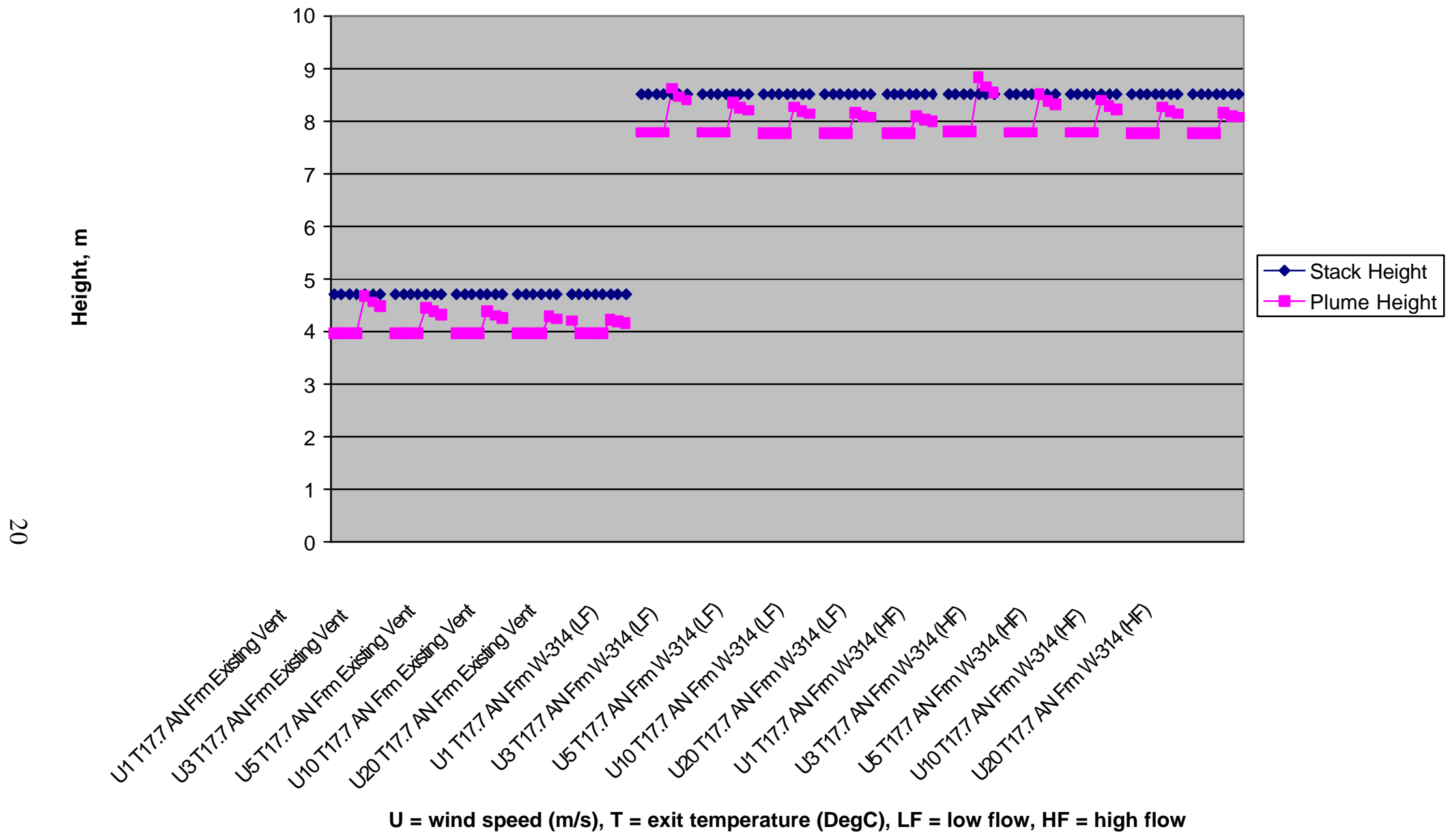

Figure 10. Computed Plume Rise for AN Tanks Farm Stacks 


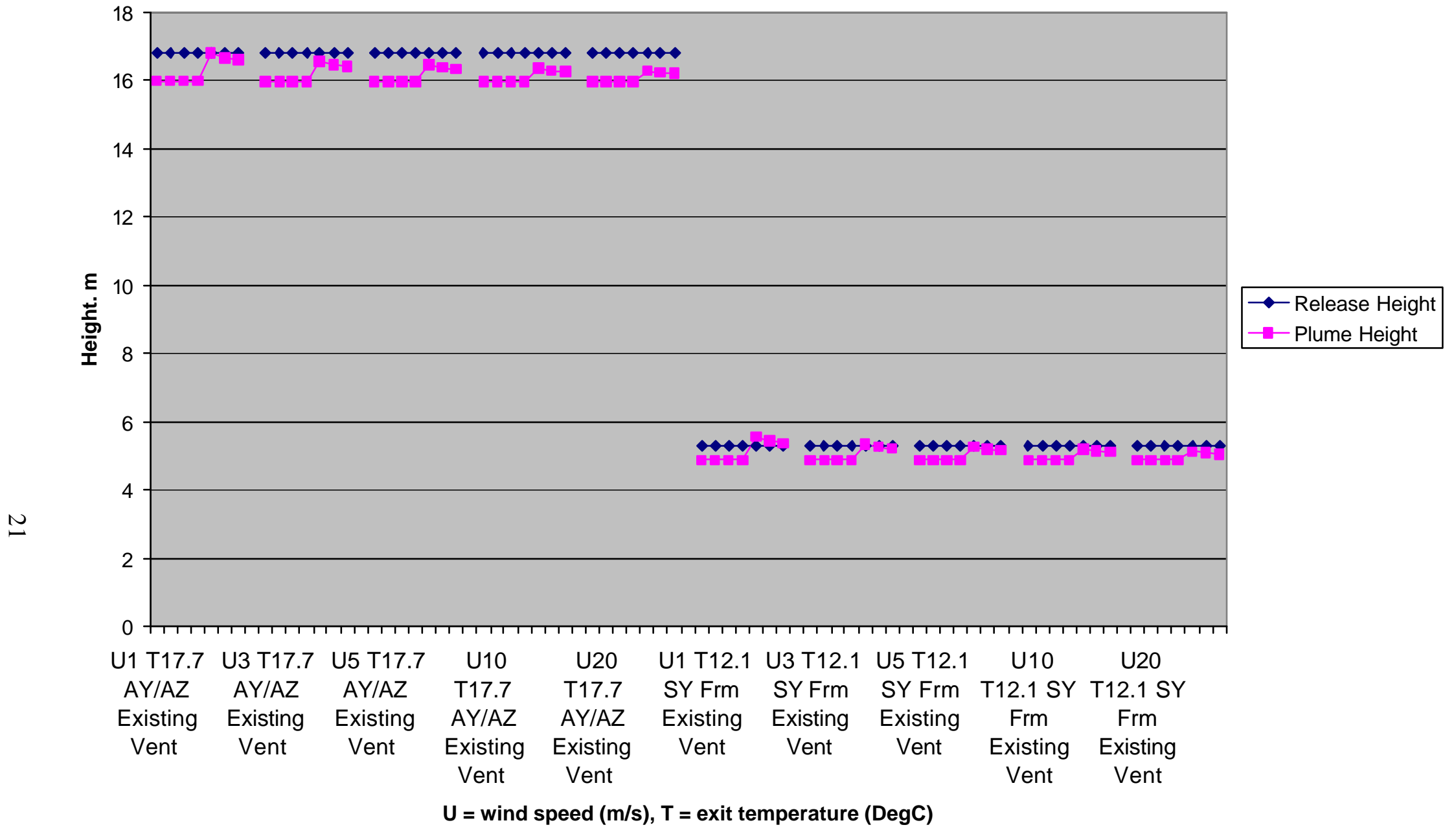

Figure 11. Computed Plume Rise for AY-AZ and SY Tank Farm Stacks 


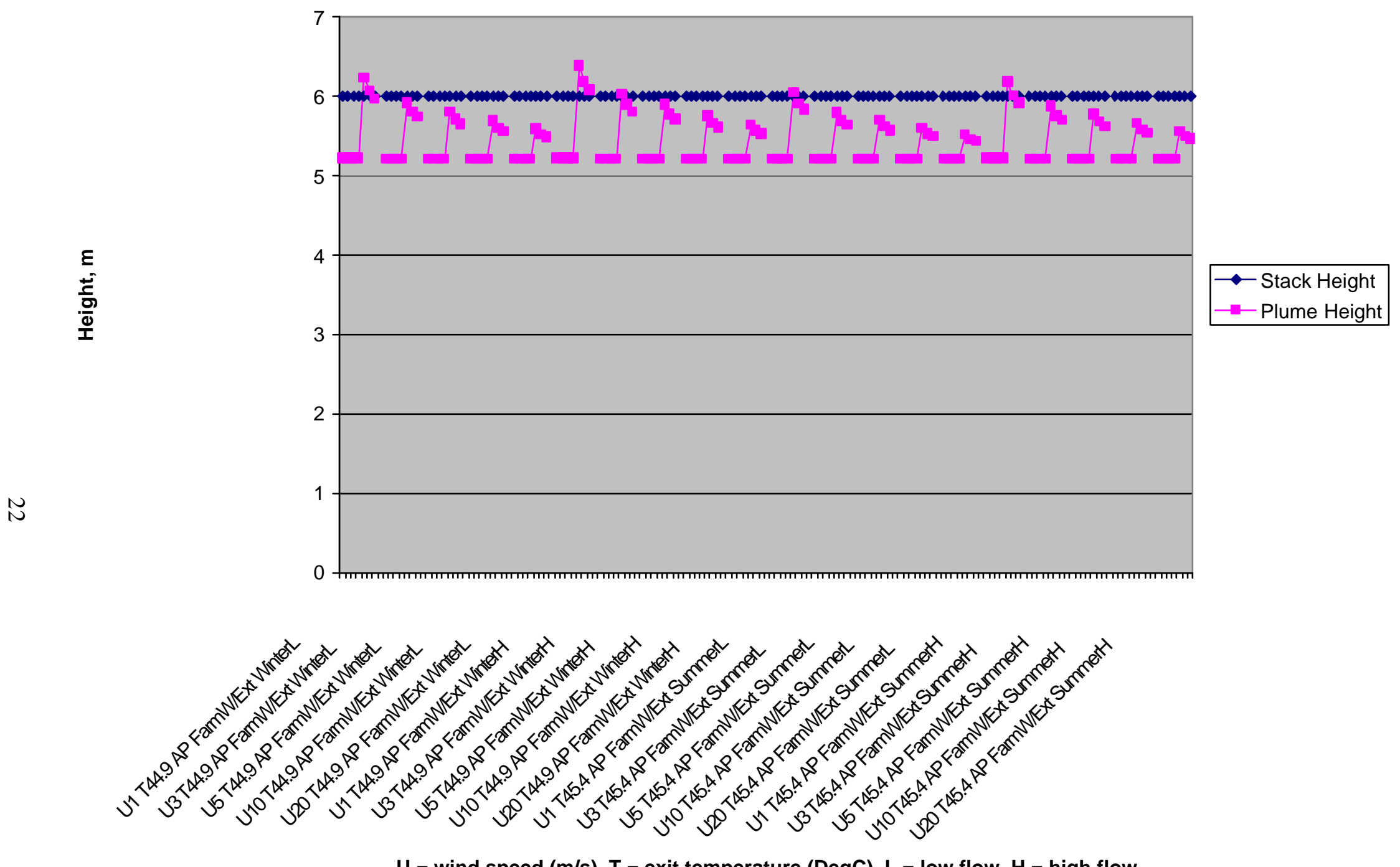

$\mathrm{U}=$ wind speed $(\mathrm{m} / \mathrm{s}), \mathrm{T}=$ exit temperature (DegC), $\mathrm{L}=$ low flow, $\mathrm{H}=$ high flow

Figure 12. Computed Plume Rise for AP Tank Farm Stacks 


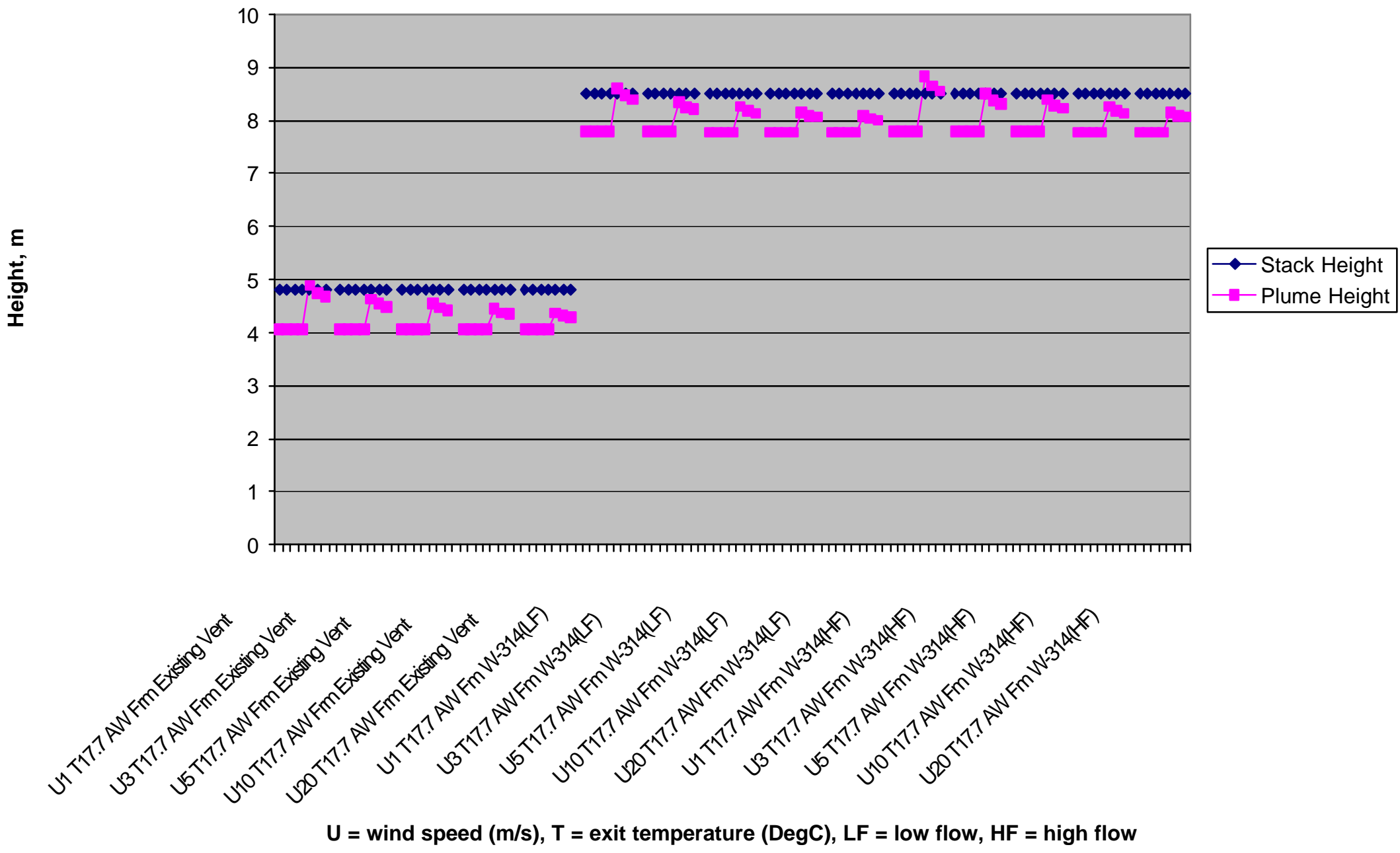

Figure 13. Computed Plume Rise for AW Tank Farm Stack 


\subsection{Air Concentrations}

Average plume concentrations in the breathing space are computed for a range of wind speeds $(1 \mathrm{~m} / \mathrm{s}-$ low, $3.2 \mathrm{~m} / \mathrm{s}$ - average, $10 \mathrm{~m} / \mathrm{s}$ - high, and $20 \mathrm{~m} / \mathrm{s}$ - extreme) and all seven stability classes (A-G). Based on the tracer study results, concentrations from each type of near-surface vent are computed for a range of ventilation rates values: $1 \mathrm{~m}^{3} / \mathrm{hr}$ (well sealed tank), $10 \mathrm{~m}^{3} / \mathrm{hr}$ (moderately venting tank) and $100 \mathrm{~m}^{3} / \mathrm{hr}$ (upper range of passive venting rates). For each forced-air stack, the concentrations are computed for the stated exit velocities (a range for several stacks). All these computations together cover the range of possible occurrences. The resulting data set is quite large. Representative values of the extremes from these computed data are presented here in graphical form. All the vents and stacks considered in the analysis are included in this discussion. Similar results are grouped in this summary of the data.

Figures 14 through 33 show the fractional concentration as a function of downwind distance representing both low and high winds combined with stable and unstable conditions. These concentration results are listed in Appendixes A and B. The figures for high winds use stabilities $\mathrm{C}$ and $\mathrm{E}$ reflecting the fact that the extremely stable and unstable classes tend to not occur under high-wind conditions. The elevated releases from stacks show both the ground level concentration (average breathing space value) and the plume centerline value. For stacks, the concentration in the breathing space is very low near the release and has a maximum at the point where the plume diffuses enough to reach down into the breathing zone. For surface-level releases, only the plume centerline value is given. 


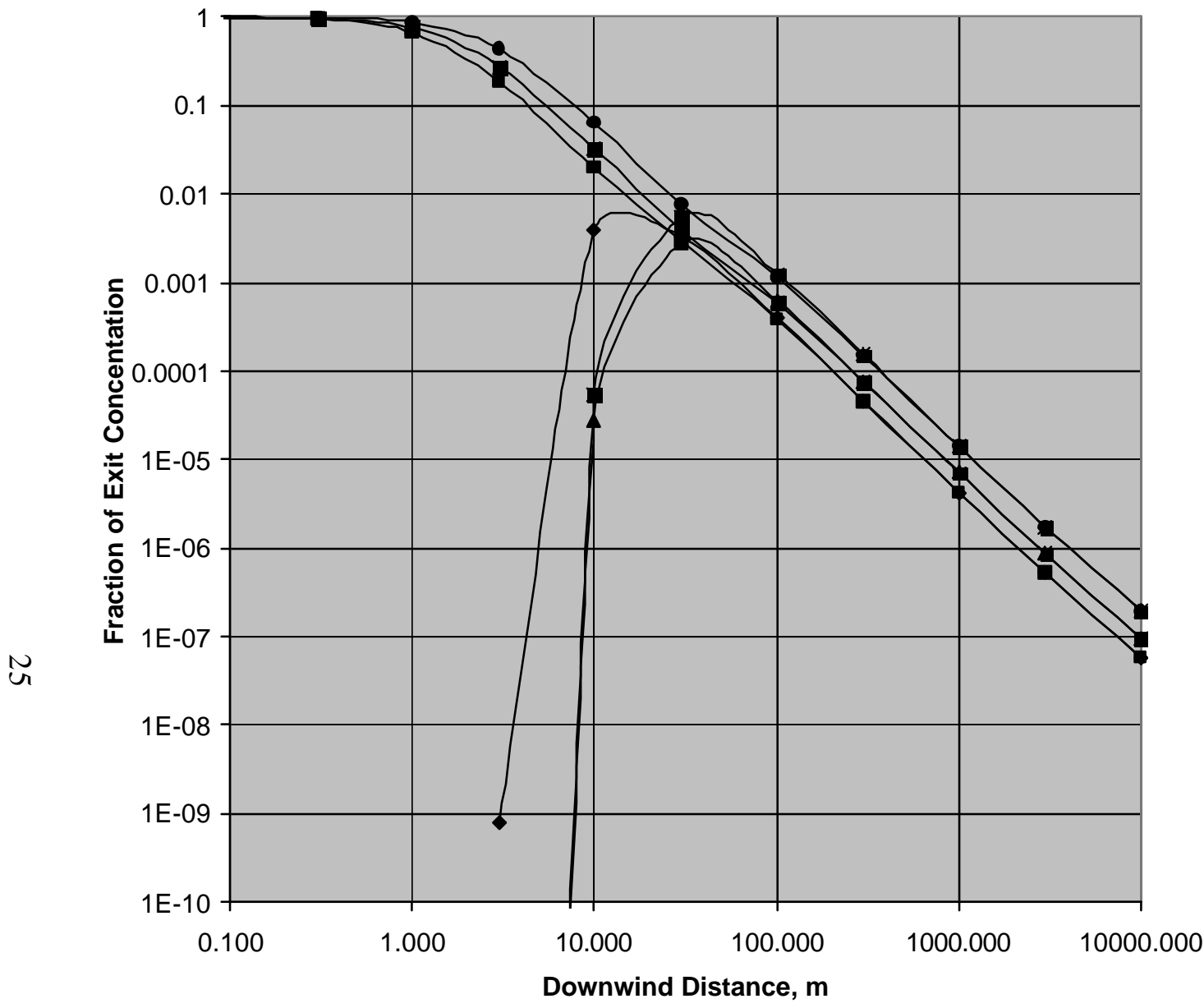
- AN Farm Existing Vent, Stability A at $\mathrm{U}=1 \mathrm{~m} / \mathrm{s}$, Ground Level
- AN Farm Existing Vent, Stability A at $\mathrm{U}=1 \mathrm{~m} / \mathrm{s}$, Plume Centerline
$\longrightarrow$ AN Farm W-314 (LF), Stability A at U $=1 \mathrm{~m} / \mathrm{s}$, Ground Level
- AN Farm W-314 (LF), Stability A at U=1m/s, Plume Centerline
- AN Farm W-314 (HF), Stability A at $\mathrm{U}=1 \mathrm{~m} / \mathrm{s}$, Ground Level
- AN Farm W-314 (HF), Stability A at $\mathrm{U}=1 \mathrm{~m} / \mathrm{s}$, Plume Centerline

Figure 14. Fractional Air Concentrations under Unstable Low-Wind Speed Conditions: AN Tank Farms 


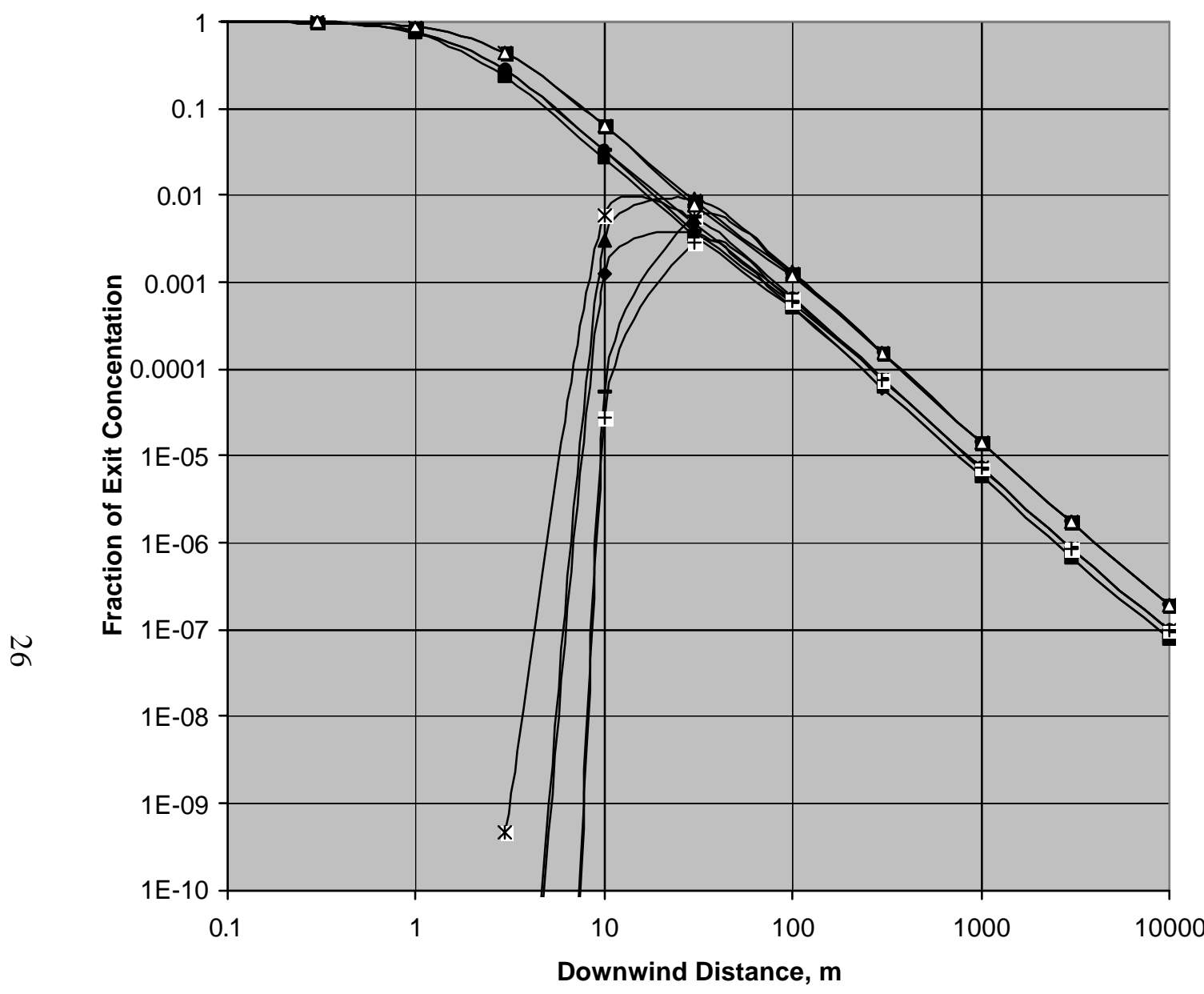

$\rightarrow-$ AP Farm W/ Extension (LF), Stability A at $U=1 \mathrm{~m} / \mathrm{s}$, Ground Level

- - AP Farm W/ Extension (LF), Stability A at $\mathrm{U}=1 \mathrm{~m} / \mathrm{s}$, Pume Centerline

$\rightarrow$ AP Farm W/ Extension (HF), Stability A at $\mathrm{U}=1 \mathrm{~m} / \mathrm{s}$, Ground Level

$\rightarrow$-AP Farm W/ Extension (HF), Stability A at $\mathrm{U}=1 \mathrm{~m} / \mathrm{s}$, Pume Centerline

-*-AW Farm Existing Vent, Stability A at $\mathrm{U}=1 \mathrm{~m} / \mathrm{s}$, Ground Level

$\longrightarrow$ AW Farm Existing Vent, Stability $A$ at $\mathrm{U}=1 \mathrm{~m} / \mathrm{s}$, Pume Centerline

--AW Farm W-314 (LF), Stability A at $\mathrm{U}=1 \mathrm{~m} / \mathrm{s}$, Ground Level

- AW Farm W-314 (LF), Stability A at $\mathrm{U}=1 \mathrm{~m} / \mathrm{s}$, Pume Centerline

- AW Farm W-314 (HF), Stability A at $\mathrm{U}=1 \mathrm{~m} / \mathrm{s}$, Ground Level

$\triangle$ AW Farm W-314 (HF), Stability A at $\mathrm{U}=1 \mathrm{~m} / \mathrm{s}$, Pume Centerline

Figure 15. Fractional Air Concentrations under Unstable Low-Wind Speed Conditions: AP and AW Tank Farms 


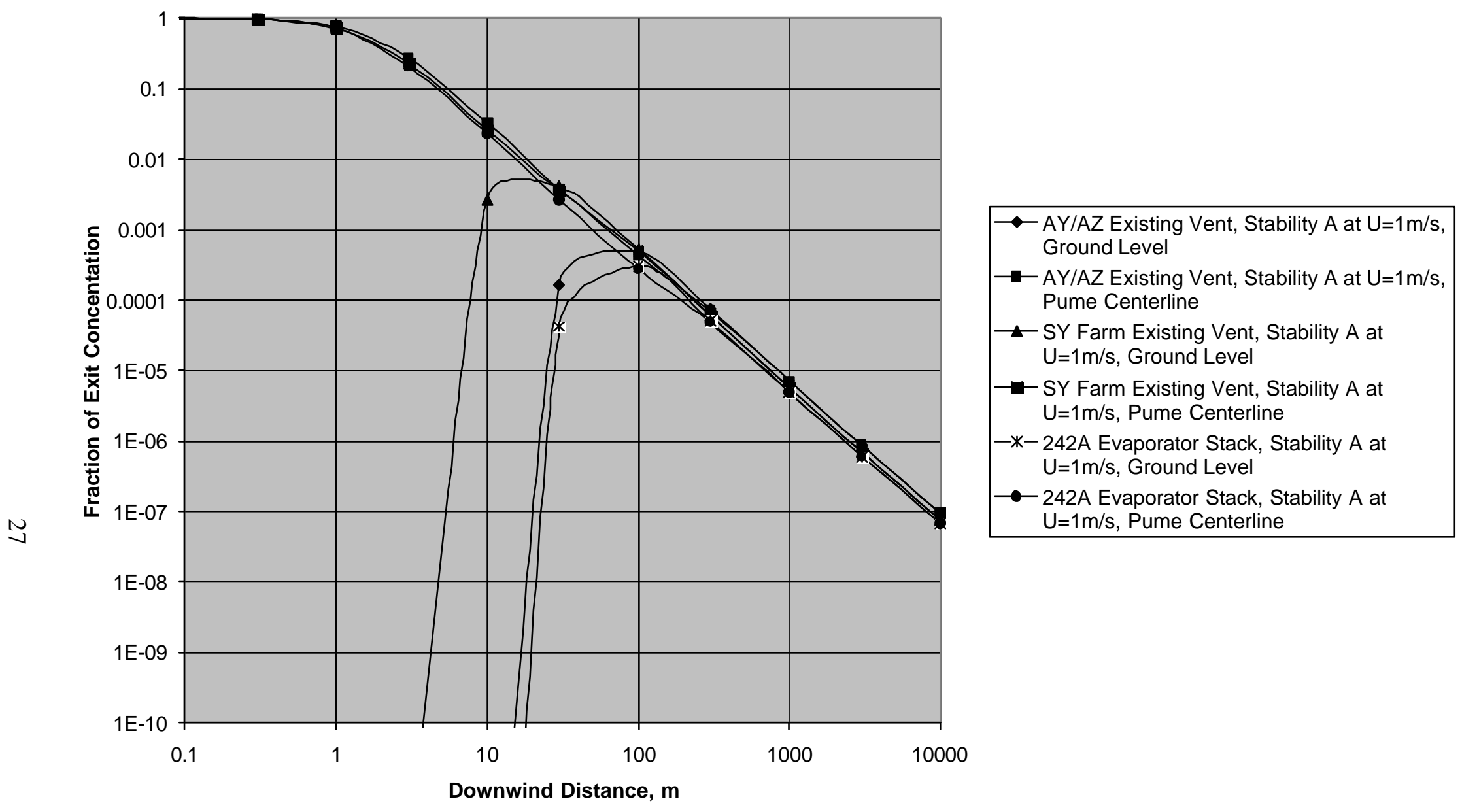

Figure 16. Fractional Air Concentrations under Unstable Low-Wind Speed Conditions: AY/AZ, SY Tank Farms and 242 A Evaporator Stack 


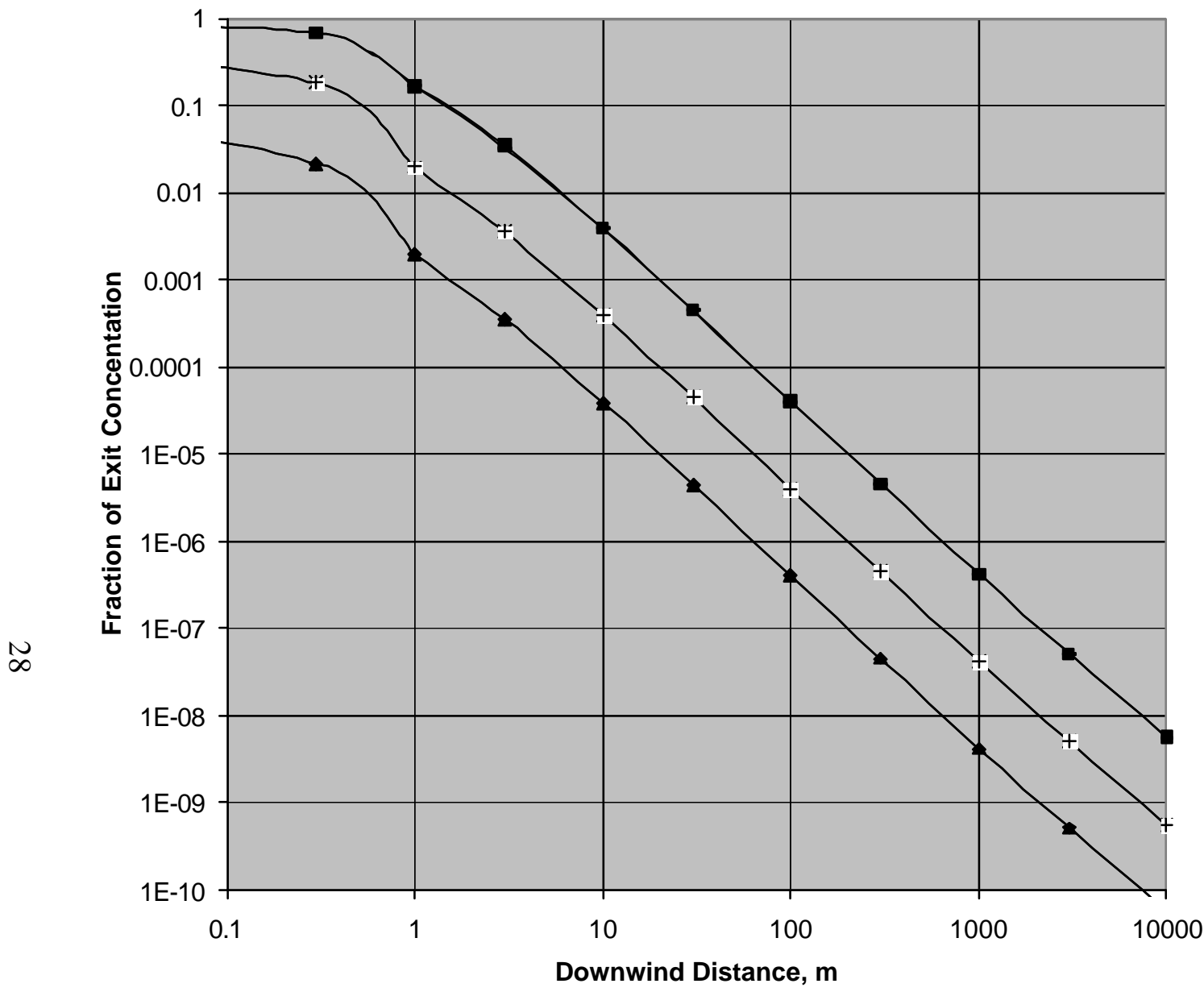
$\neg 4$ Inch Pipe (Near surface), Stability A at $\mathrm{U}=1 \mathrm{~m} / \mathrm{s}, \mathrm{E}=1 \mathrm{~m} 3 / \mathrm{hr}$
- Near Surface Box Filter Vent, Stability A at $\mathrm{U}=1 \mathrm{~m} / \mathrm{s}, \mathrm{E}=1 \mathrm{~m} 3 / \mathrm{hr}$
$-*-4$ Inch Pipe (Near surface), Stability $A$ at $\mathrm{U}=1 \mathrm{~m} / \mathrm{s}, \mathrm{E}=10 \mathrm{~m} 3 / \mathrm{hr}$
- - Near Surface Box Filter Vent, Stability A at $\mathrm{U}=1 \mathrm{~m} / \mathrm{s}, \mathrm{E}=10 \mathrm{~m} 3 / \mathrm{hr}$
-4 Inch Pipe (Near surface), Stability $A$ at $\mathrm{U}=1 \mathrm{~m} / \mathrm{s}, \mathrm{E}=100 \mathrm{~m} 3 / \mathrm{hr}$
$\rightarrow-N e a r$ Surface Box Filter Vent, Stability A at $\mathrm{U}=1 \mathrm{~m} / \mathrm{s}, \mathrm{E}=100 \mathrm{~m} 3 / \mathrm{hr}$

Figure 17. Fractional Air Concentrations under Unstable Low-Wind Speed Conditions: Near-Surface Passive Vents 


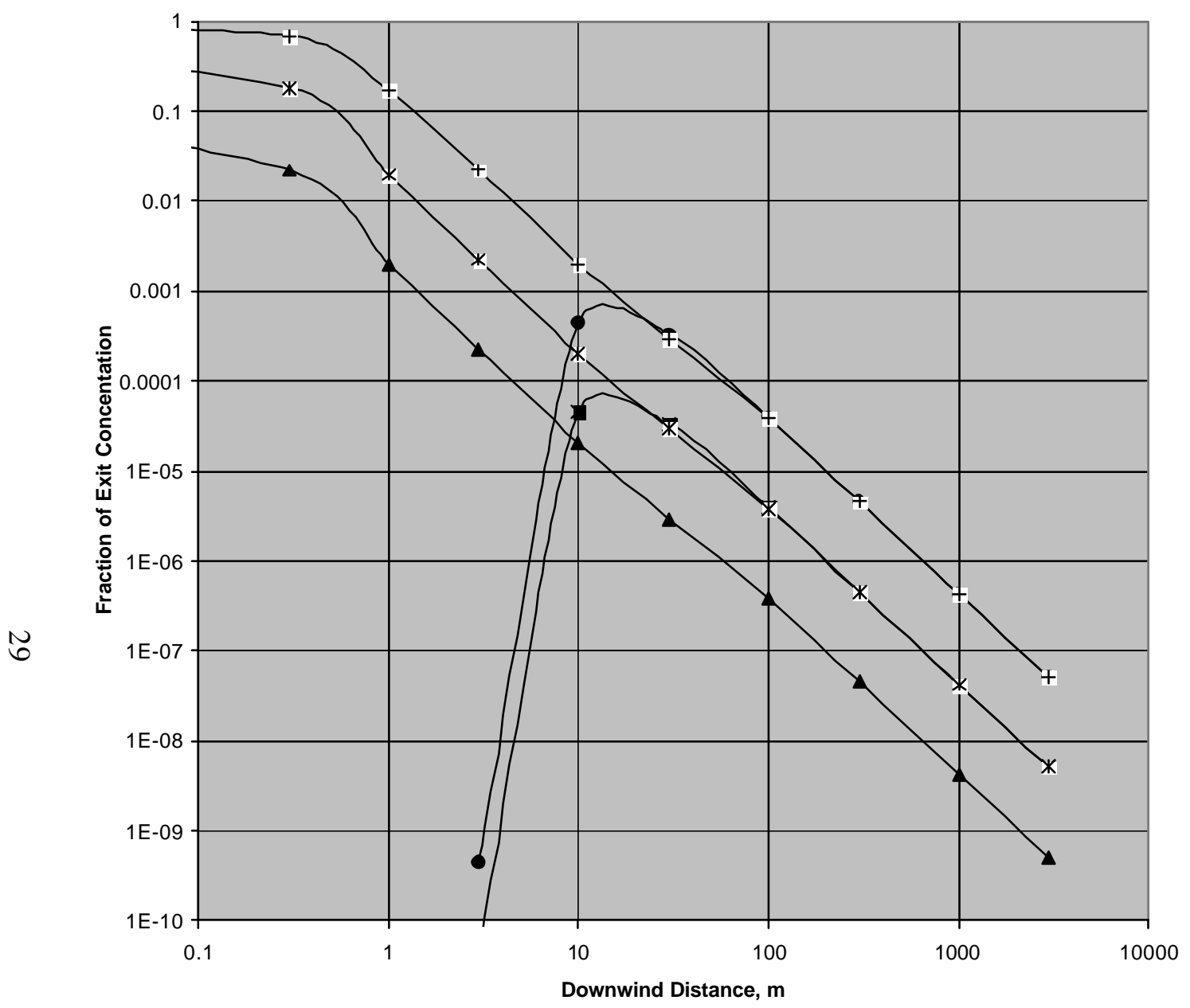
-4 Inch Pipe (Stack), Stability A at U=1m/s, E= $1 \mathrm{~m} 3 / \mathrm{hr}$, Pume Centerline
- 4 Inch Pipe (Stack), Stability A at U=1m/s, E= $10 \mathrm{~m} 3 / \mathrm{hr}$, Ground Level
- $*-4$ Inch Pipe (Stack), Stability $A$ at $U=1 \mathrm{~m} / \mathrm{s}, E=10 \mathrm{~m} 3 / \mathrm{hr}$, Pume Centerline
4 Inch Pipe (Stack), Stability $A$ at $U=1 \mathrm{~m} / \mathrm{s}, E=100$ $\mathrm{m} 3 / \mathrm{hr}$, Ground Level
+-4 Inch Pipe (Stack), Stability A at U=1m/s, E= 100 $\mathrm{m} 3 / \mathrm{hr}$, Pume Centerline

Figure 18. Fractional Air Concentrations under Unstable Low-Wind Speed Conditions: Passively Vented Stack 


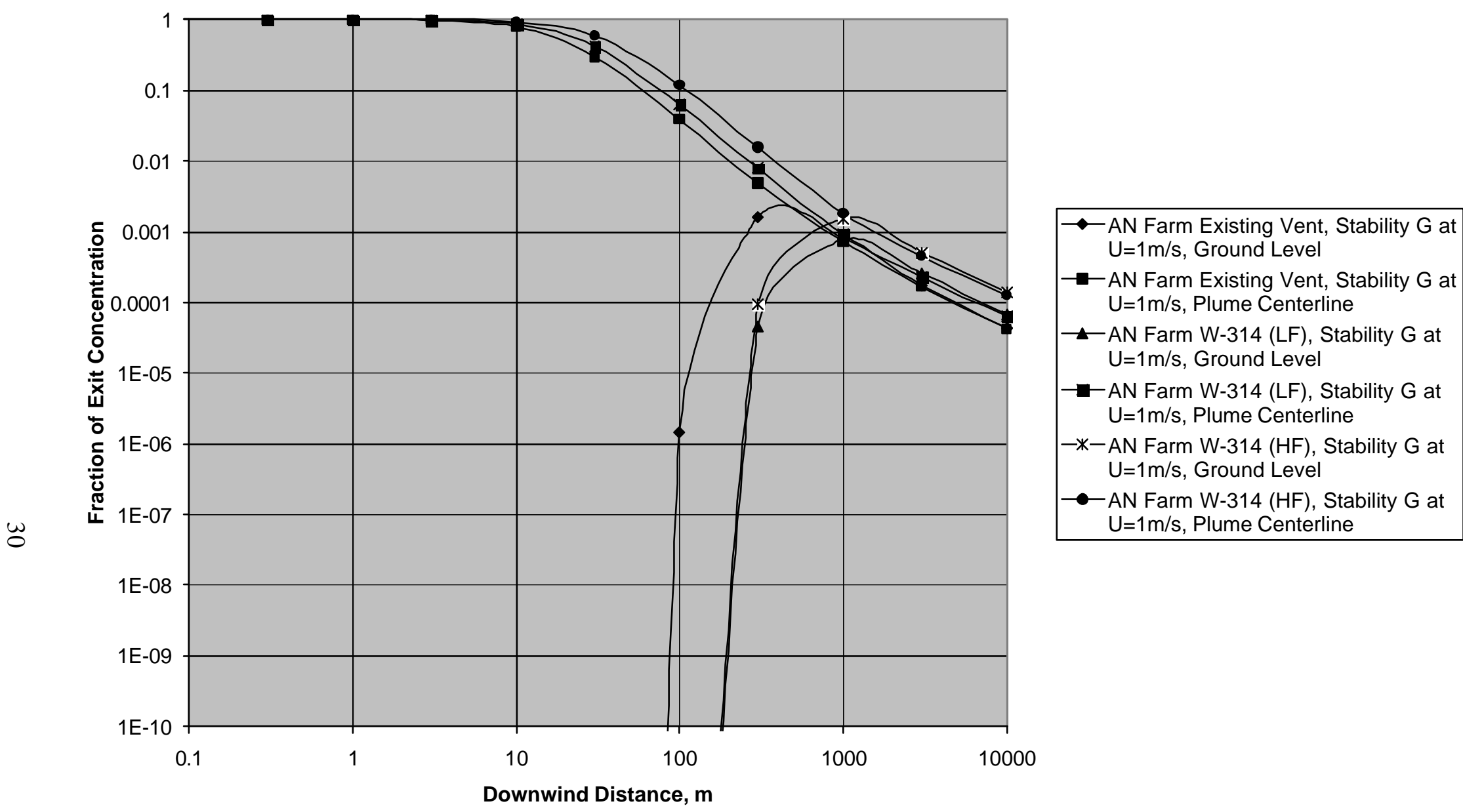

Figure 19. Fractional Air Concentrations under Stable Low-Wind Speed Conditions: AN Tank Farm Vents 


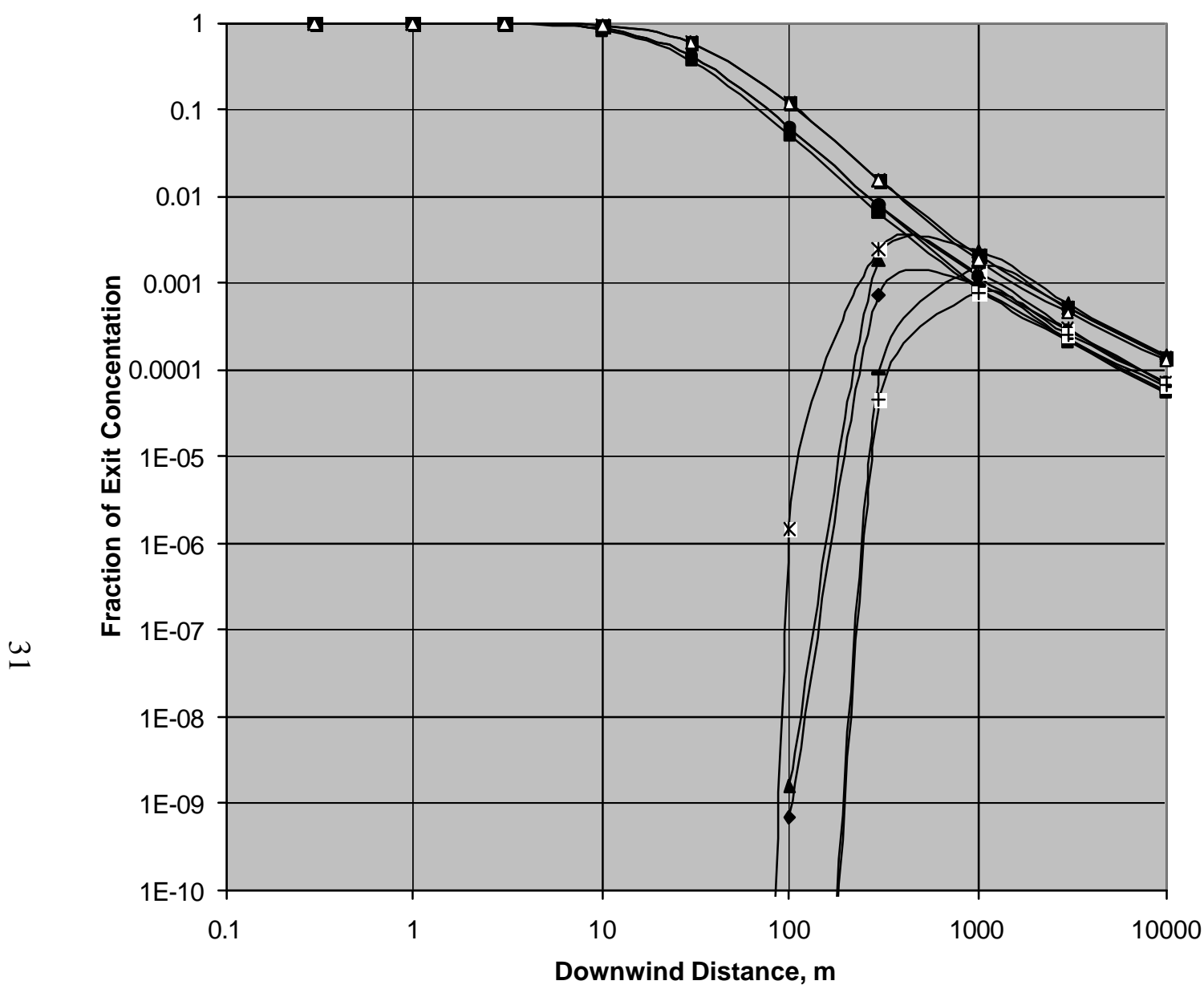

$\rightarrow-$ AP Farm W/ Extension (LF), Stability G at $U=1 \mathrm{~m} / \mathrm{s}$, Ground Level

- AP Farm W/ Extension (LF), Stability G at $U=1 \mathrm{~m} / \mathrm{s}$, Plume Centerline

$\triangle$ AP Farm W/ Extension (HF), Stability G at $U=1 \mathrm{~m} / \mathrm{s}$, Ground Level

$\rightarrow-A P$ Farm W/ Extension (HF), Stability G at $\mathrm{U}=1 \mathrm{~m} / \mathrm{s}$, Plume Centerline

-*-AW Farm Existing Vent, Stability $G$ at $\mathrm{U}=1 \mathrm{~m} / \mathrm{s}$, Ground Level

- AW Farm Existing Vent, Stability $G$ at $\mathrm{U}=1 \mathrm{~m} / \mathrm{s}$, Plume Centerline

--AW Farm W-314 (LF), Stability G at $\mathrm{U}=1 \mathrm{~m} / \mathrm{s}$, Ground Level

- AW Farm W-314 (LF), Stability G at $\mathrm{U}=1 \mathrm{~m} / \mathrm{s}$, Plume Centerline

- AW Farm W-314 (HF), Stability G at $\mathrm{U}=1 \mathrm{~m} / \mathrm{s}$, Ground Level

$\triangle$ AW Farm W-314 (HF), Stability G at $\mathrm{U}=1 \mathrm{~m} / \mathrm{s}$, Plume Centerline

Figure 20. Fractional Air Concentrations under Stable Low-Wind Speed Conditions: AP and AW Tank Farm Vents 


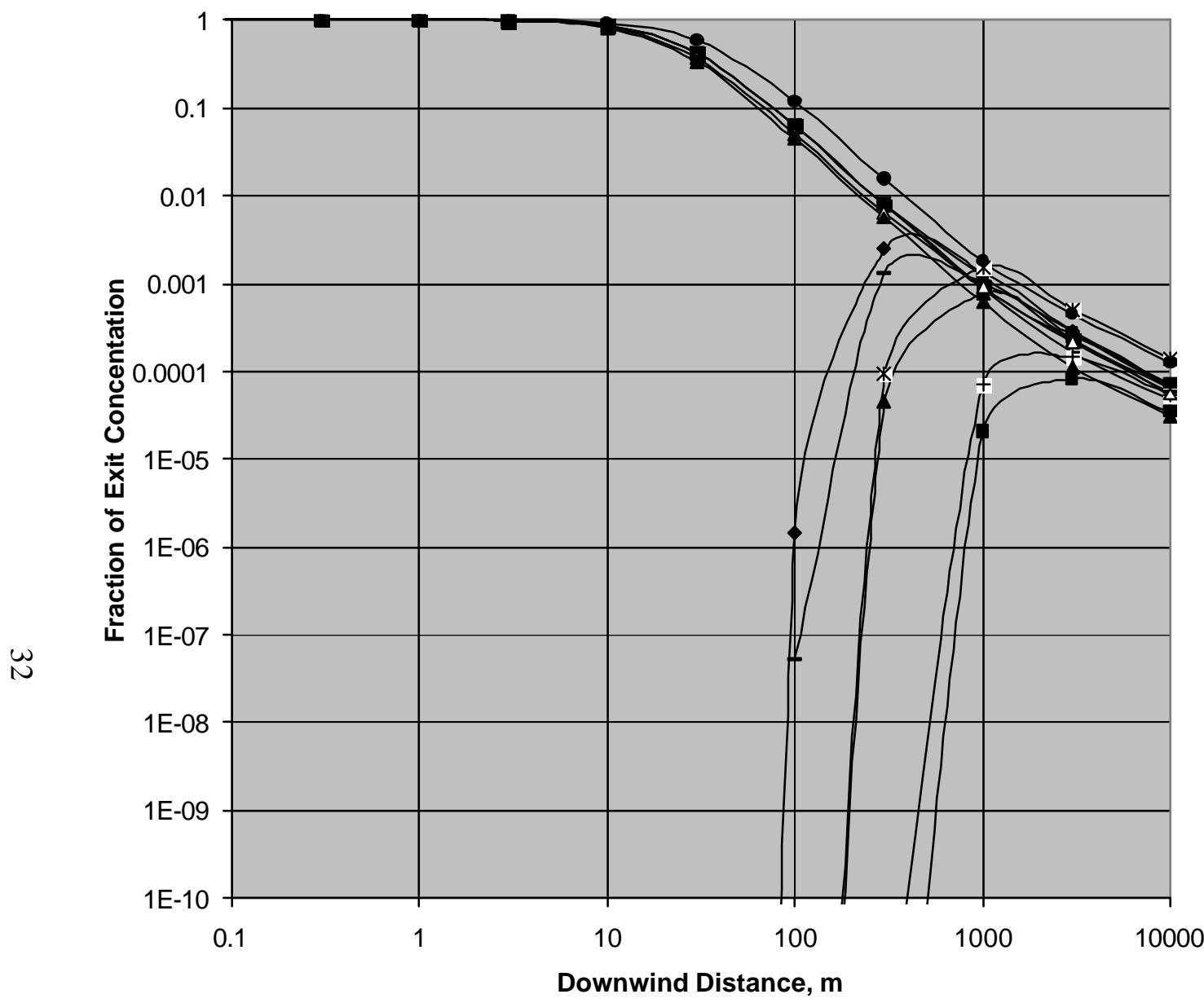
$\neg$ AW Farm Existing Vent, Stability G at $\mathrm{U}=1 \mathrm{~m} / \mathrm{s}$, Ground Level
- AW Farm Existing Vent, Stability G at $\mathrm{U}=1 \mathrm{~m} / \mathrm{s}$, Plume Centerline
— AW Farm W-314 (LF), Stability G at $\mathrm{U}=1 \mathrm{~m} / \mathrm{s}$, Ground Level
$\rightarrow$ - AW Farm W-314 (LF), Stability G at $\mathrm{U}=1 \mathrm{~m} / \mathrm{s}$, Plume Centerline
-*-AW Farm W-314 (HF), Stability G at $\mathrm{U}=1 \mathrm{~m} / \mathrm{s}$, Ground Level
- AW Farm W-314 (HF), Stability G at $\mathrm{U}=1 \mathrm{~m} / \mathrm{s}$, Plume Centerline
+-AY/AZ Existing Vent, Stability $G$ at $U=1 \mathrm{~m} / \mathrm{s}$, Ground Level
- AY/AZ Existing Vent, Stability $G$ at $U=1 \mathrm{~m} / \mathrm{s}$, Plume Centerline
- SY Farm Existing Vent, Stability G at $\mathrm{U}=1 \mathrm{~m} / \mathrm{s}$, Ground Level
$\neg$ SY Farm Existing Vent, Stability $G$ at $\mathrm{U}=1 \mathrm{~m} / \mathrm{s}$, Plume Centerline
- 242A Evaporator Stack, Stability G at $\mathrm{U}=1 \mathrm{~m} / \mathrm{s}$, Ground Level
$-242 \mathrm{~A}$ Evaporator Stack, Stability $\mathrm{G}$ at $\mathrm{U}=1 \mathrm{~m} / \mathrm{s}$, Plume Centerline

Figure 21. Fractional Air Concentrations under Stable Low-Wind Speed Conditions: AY/AZ, SY Tank Farms and 242 A Evaporator Stack 


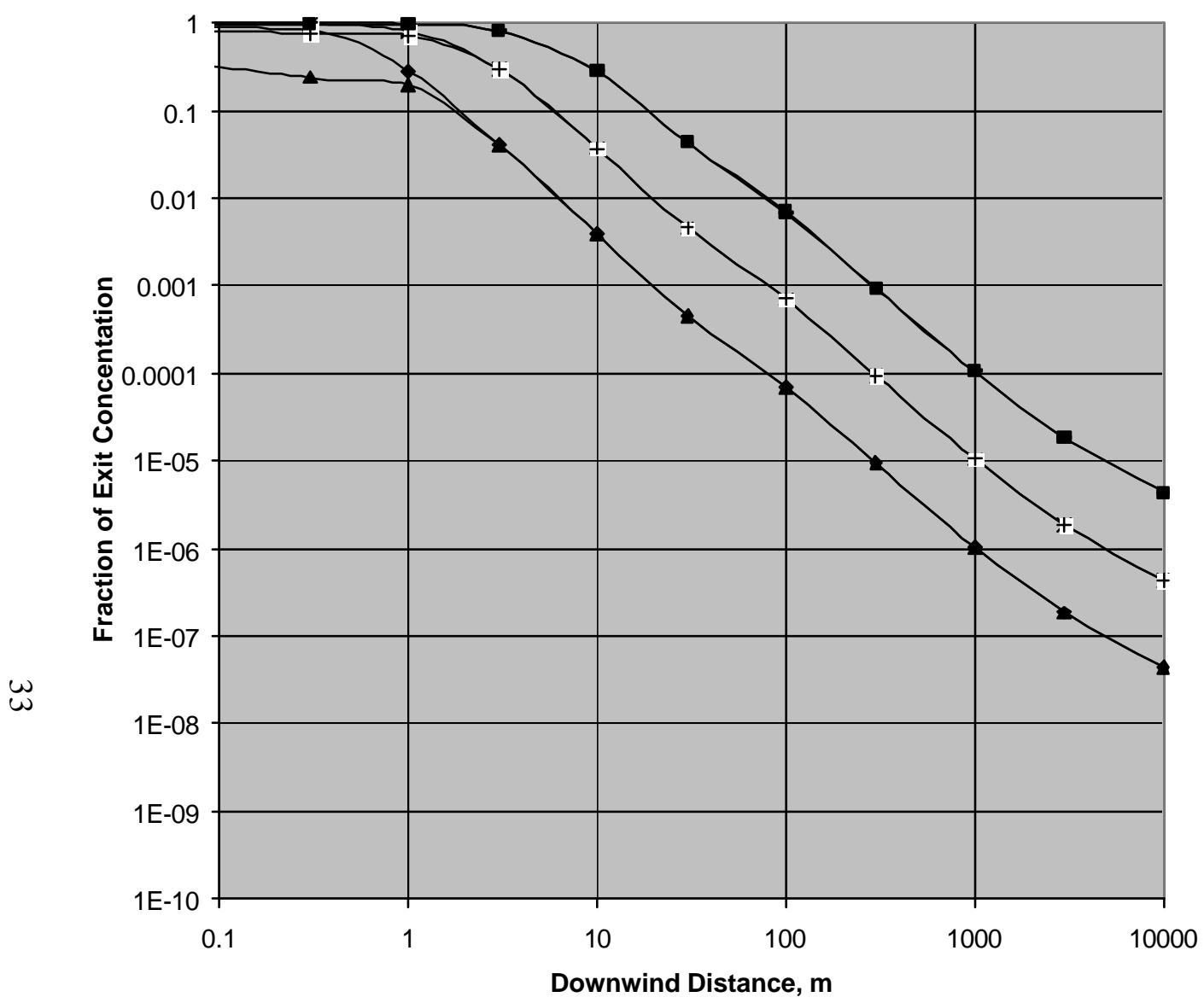
$\multimap-4$ Inch Pipe (Near surface), Stability G at $\mathrm{U}=1 \mathrm{~m} / \mathrm{s}, E=1 \mathrm{~m} 3 / \mathrm{hr}$

^-Near Surface Box Filter Vent, Stability G at $\mathrm{U}=1 \mathrm{~m} / \mathrm{s}, \mathrm{E}=1 \mathrm{~m} 3 / \mathrm{hr}$

$-*-4$ Inch Pipe (Near surface), Stability $G$ at $\mathrm{U}=1 \mathrm{~m} / \mathrm{s}, \mathrm{E}=10 \mathrm{~m} 3 / \mathrm{hr}$

- Near Surface Box Filter Vent, Stability G at $\mathrm{U}=1 \mathrm{~m} / \mathrm{s}, \mathrm{E}=10 \mathrm{m3} / \mathrm{hr}$

- 4 Inch Pipe (Near surface), Stability $G$ at $\mathrm{U}=1 \mathrm{~m} / \mathrm{s}, \mathrm{E}=100 \mathrm{~m} 3 / \mathrm{hr}$

$\rightarrow-N e a r$ Surface Box Filter Vent, Stability G at $\mathrm{U}=1 \mathrm{~m} / \mathrm{s}, \mathrm{E}=100 \mathrm{~m} 3 / \mathrm{hr}$

Figure 22. Fractional Air Concentrations under Stable Low-Wind Speed Conditions: Near-Surface Passive Vents 


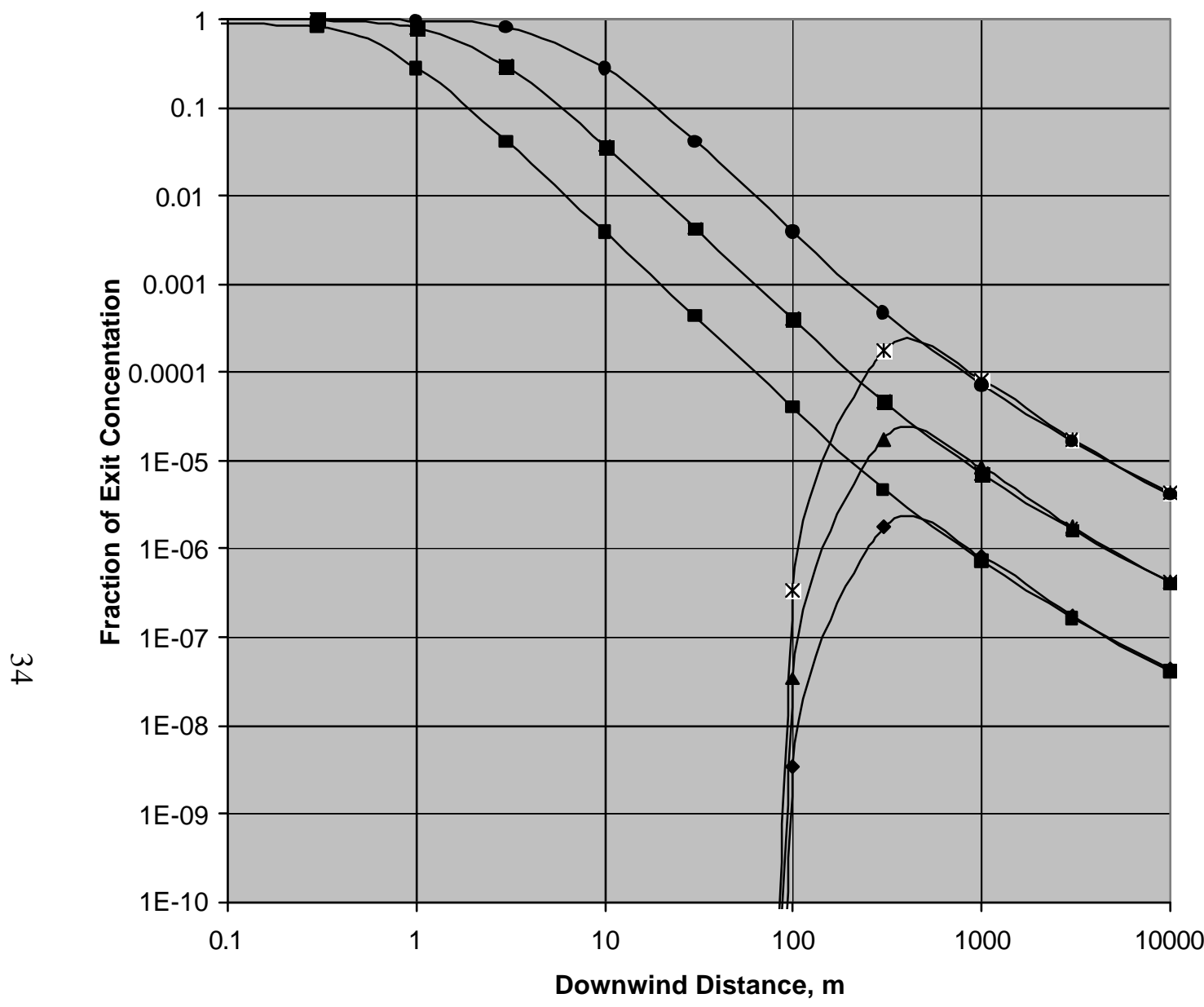
$\longrightarrow-4$ Inch Pipe (Stack), Stability $\mathrm{G}$ at $\mathrm{U}=1 \mathrm{~m} / \mathrm{s}$, $\mathrm{E}=1 \mathrm{~m} 3 / \mathrm{hr}$, Ground Level
-4 Inch Pipe (Stack), Stability $G$ at $U=1 \mathrm{~m} / \mathrm{s}$, $\mathrm{E}=1 \mathrm{~m} 3 / \mathrm{hr}$, Plume Centerline
$\multimap 4$ Inch Pipe (Stack), Stability $G$ at $U=10$ $\mathrm{m} / \mathrm{s}, \mathrm{E}=10 \mathrm{~m} 3 / \mathrm{hr}$, Ground Level
-4 Inch Pipe (Stack), Stability $\mathrm{G}$ at $\mathrm{U}=10$ $\mathrm{m} / \mathrm{s}, \mathrm{E}=10 \mathrm{~m} 3 / \mathrm{hr}$, Plume Centerline
- - 4 Inch Pipe (Stack), Stability $G$ at $U=100$ $\mathrm{m} / \mathrm{s}, \mathrm{E}=100 \mathrm{~m} 3 / \mathrm{hr}$, Ground Level
-4 Inch Pipe (Stack), Stability $G$ at $U=100$ $\mathrm{m} / \mathrm{s}, \mathrm{E}=100 \mathrm{~m} 3 / \mathrm{hr}$, Plume Centerline

Figure 23. Fractional Air Concentrations under Stable Low-Wind Speed Conditions: Passively Vented Stack 


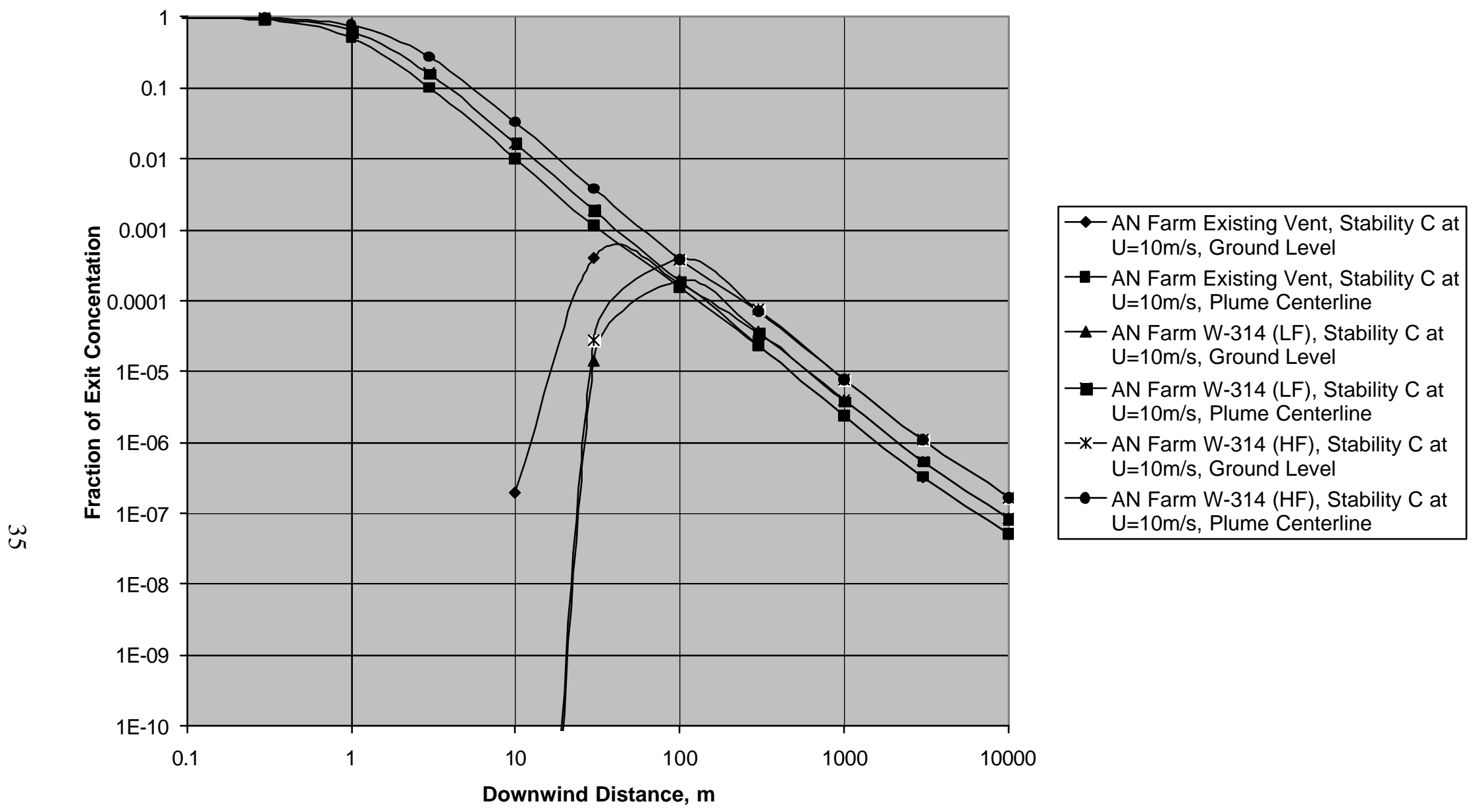

Figure 24. Fractional Air Concentrations under Unstable High-Wind Speed Conditions: AN Tank Farm Vents 


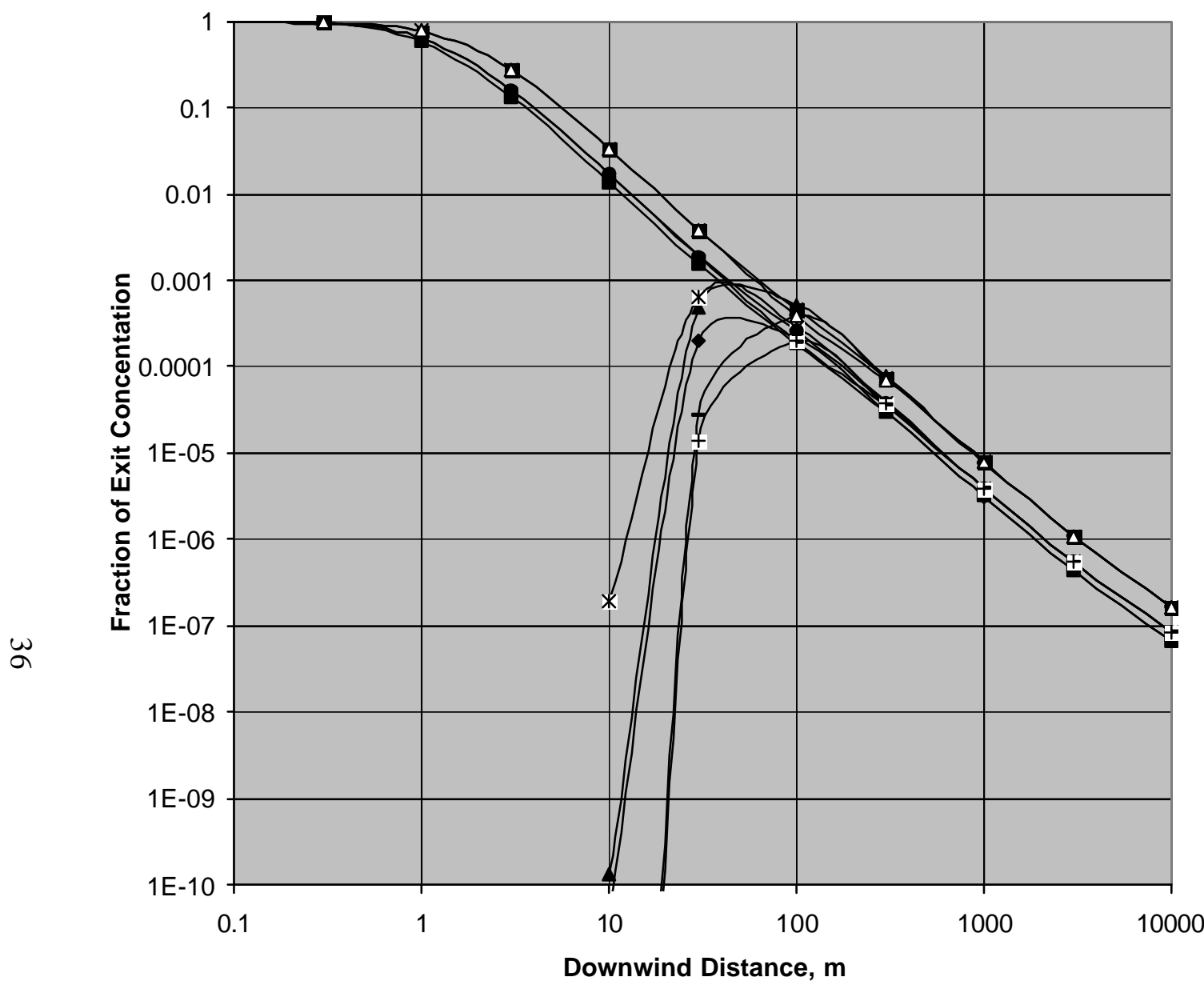
$\rightarrow-$ AP Farm W/ Extension (LF), Stability C at $\mathrm{U}=10 \mathrm{~m} / \mathrm{s}$, Ground Level
$\rightarrow-$ AP Farm W/ Extension (LF), Stability $C$ at $\mathrm{U}=10 \mathrm{~m} / \mathrm{s}$, Plume Centerline
$\rightarrow$ AP Farm W/ Extension (HF), Stability $C$ at $\mathrm{U}=10 \mathrm{~m} / \mathrm{s}$, Ground Level
$\rightarrow$ AP Farm W/ Extension (HF), Stability $\mathrm{C}$ at $\mathrm{U}=10 \mathrm{~m} / \mathrm{s}$, Plume Centerline
-*-AW Farm Existing Vent, Stability $C$ at $\mathrm{U}=10 \mathrm{~m} / \mathrm{s}$, Ground Level
- AW Farm Existing Vent, Stability $C$ at $\mathrm{U}=10 \mathrm{~m} / \mathrm{s}$, Plume Centerline
- - AW Farm W-314 (LF), Stability C at $\mathrm{U}=10 \mathrm{~m} / \mathrm{s}$, Ground Level
- AW Farm W-314 (LF), Stability C at $\mathrm{U}=10 \mathrm{~m} / \mathrm{s}$, Plume Centerline
- AW Farm W-314 (HF), Stability C at $\mathrm{U}=10 \mathrm{~m} / \mathrm{s}$, Ground Level
$\triangle$ AW Farm W-314 (HF), Stability C at $\mathrm{U}=10 \mathrm{~m} / \mathrm{s}$, Plume Centerline

Figure 25. Fractional Air Concentrations under Unstable High-Wind Speed Conditions: AP and AW Tank Farm Vents 


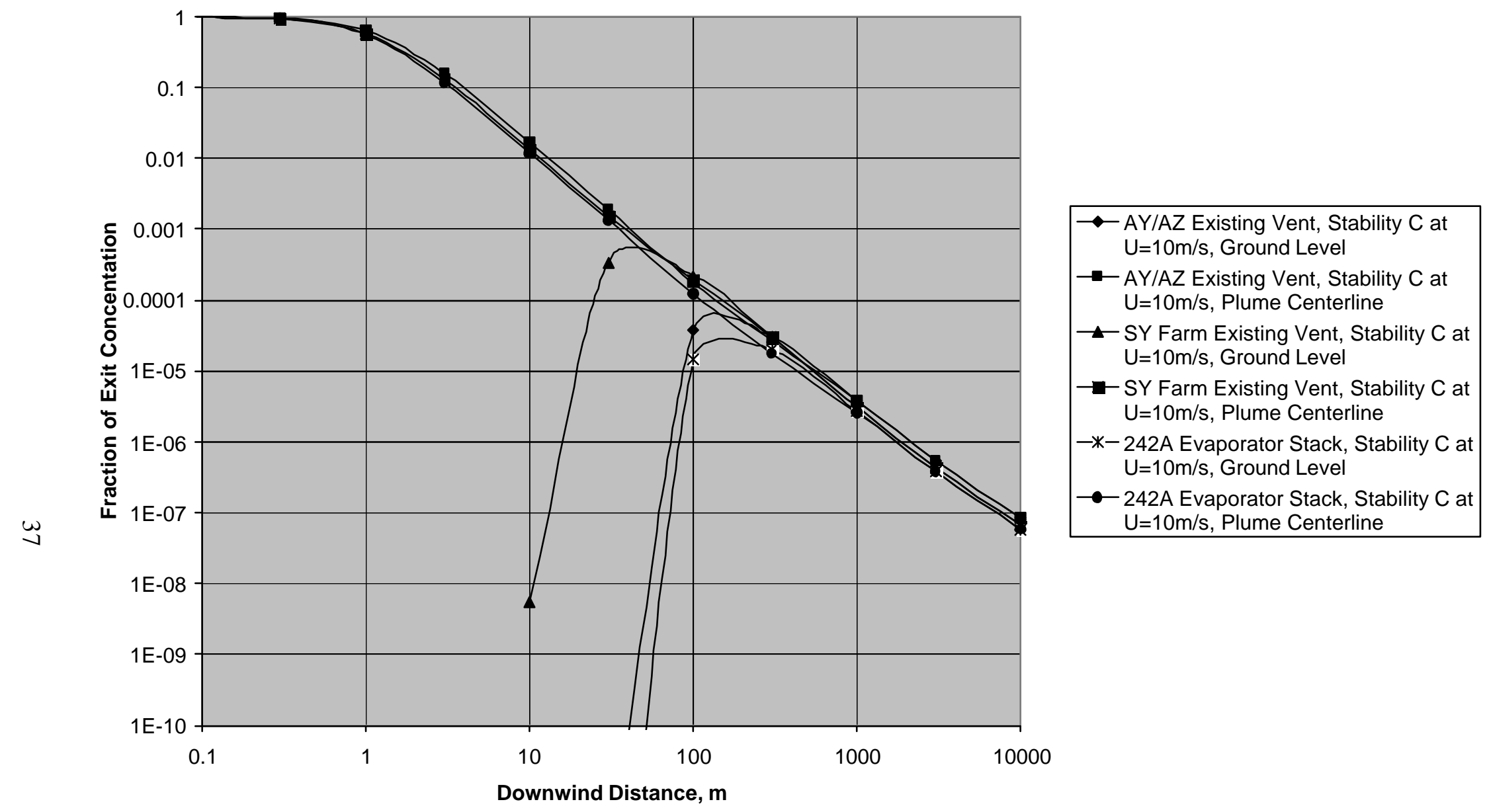

Figure 26. Fractional Air Concentrations under Unstable High-Wind Speed Conditions: AY/AZ, SY Tank Farms and 242 A Evaporator Stack 


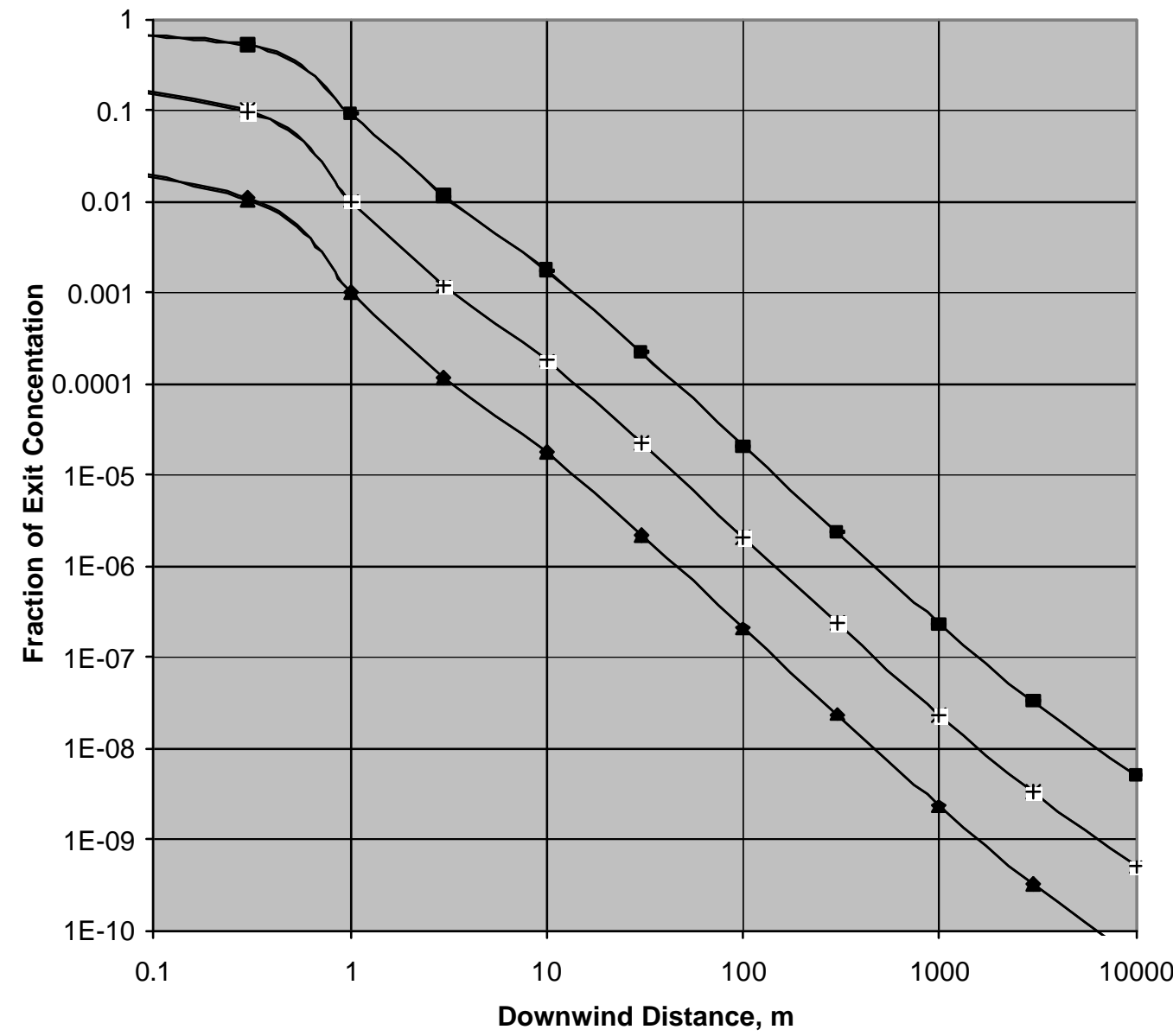

4 Inch Pipe (Near surface), Stability $C$ a $\mathrm{U}=10 \mathrm{~m} / \mathrm{s}, \mathrm{E}=1 \mathrm{~m} 3 / \mathrm{hr}$ Plume Centerline

- Near Surface Box Filter Vent, Stability $C$ at $\mathrm{U}=10 \mathrm{~m} / \mathrm{s}, \mathrm{E}=1 \mathrm{~m} 3 / \mathrm{hr}$ Plume Centerline

$-*-4$ Inch Pipe (Near surface), Stability $C$ at $\mathrm{U}=10 \mathrm{~m} / \mathrm{s}, \mathrm{E}=10 \mathrm{~m} 3 / \mathrm{hr}$ Plume Centerline

+-Near Surface Box Filter Vent, Stability $C$ at $\mathrm{U}=10 \mathrm{~m} / \mathrm{s}, \mathrm{E}=10 \mathrm{~m} 3 / \mathrm{hr}$ Plume Centerline

- 4 Inch Pipe (Near surface), Stability $C$ at $\mathrm{U}=10 \mathrm{~m} / \mathrm{s}, \mathrm{E}=100 \mathrm{~m} 3 / \mathrm{hr}$ Plume Centerline

- Near Surface Box Filter Vent, Stability C at $\mathrm{U}=10 \mathrm{~m} / \mathrm{s}, \mathrm{E}=100 \mathrm{~m} 3 / \mathrm{hr}$ Plume Centerline

Figure 27. Fractional Air Concentrations under Unstable High-Wind Speed Conditions: Near-Surface Passive Vents 


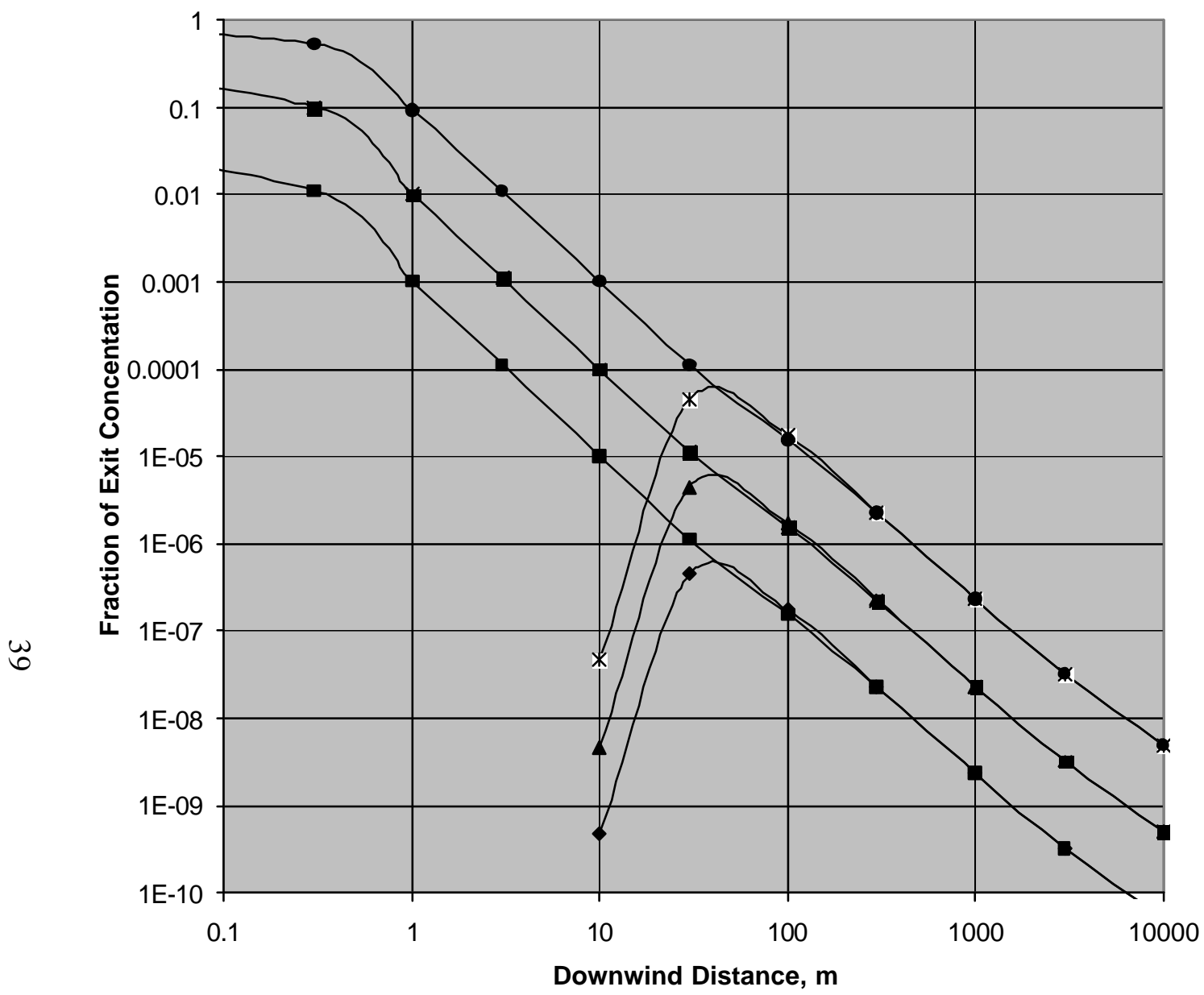
$\multimap 4$ Inch Pipe (Stack), Stability $\mathrm{C}$ at $\mathrm{U}=10 \mathrm{~m} / \mathrm{s}$, $\mathrm{E}=1 \mathrm{~m} 3 / \mathrm{hr}$, Ground Level
- 4 Inch Pipe (Stack), Stability $C$ at $U=10 \mathrm{~m} / \mathrm{s}$, $\mathrm{E}=1 \mathrm{~m} 3 / \mathrm{hr}$, Plume Centerline
-4 Inch Pipe (Stack), Stability $C$ at $U=10 \mathrm{~m} / \mathrm{s}$, $\mathrm{E}=10 \mathrm{~m} 3 / \mathrm{hr}$, Ground Level
-4 Inch Pipe (Stack), Stability $C$ at $U=10 \mathrm{~m} / \mathrm{s}$, $E=10 \mathrm{~m} 3 / \mathrm{hr}$, Plume Centerline
$-*-4$ Inch Pipe (Stack), Stability $C$ at $U=10 \mathrm{~m} / \mathrm{s}$, $E=100 \mathrm{~m} 3 / \mathrm{hr}$, Ground Level
- 4 Inch Pipe (Stack), Stability $C$ at $U=10 \mathrm{~m} / \mathrm{s}$, $\mathrm{E}=100 \mathrm{~m} 3 / \mathrm{hr}$, Plume Centerline

Figure 28. Fractional Air Concentrations under Unstable High-Wind Speed Conditions: Passively Vented Stack 


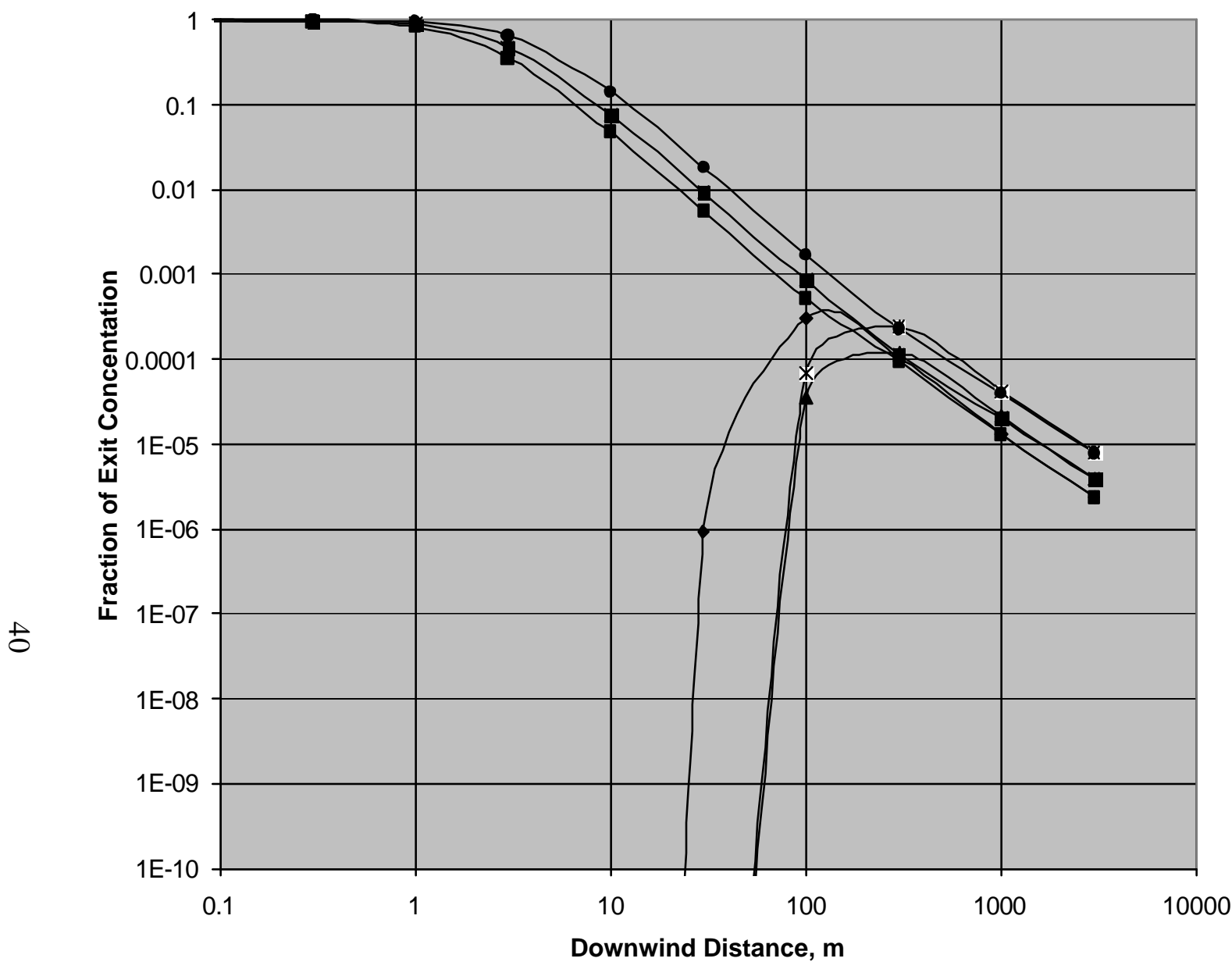

$\leftarrow$ AN Farm Existing Vent, Stability E at $\mathrm{U}=10 \mathrm{~m} / \mathrm{s}$, Ground Level

$\rightarrow-A N$ Farm Existing Vent, Stability E at $\mathrm{U}=10 \mathrm{~m} / \mathrm{s}$, Plume Centerline

- AN Farm W-314 (LF), Stability E at $\mathrm{U}=10 \mathrm{~m} / \mathrm{s}$, Ground Level

-AN Farm W-314 (LF), Stability E at $\mathrm{U}=10 \mathrm{~m} / \mathrm{s}$, Plume Centerline

-*-AN Farm W-314 (HF), Stability E at $\mathrm{U}=10 \mathrm{~m} / \mathrm{s}$, Ground Level

- AN Farm W-314 (HF), Stability E at $\mathrm{U}=10 \mathrm{~m} / \mathrm{s}$, Plume Centerline

Figure 29. Fractional Air Concentrations under Stable High-Wind Speed Conditions : AN Tank Farm 


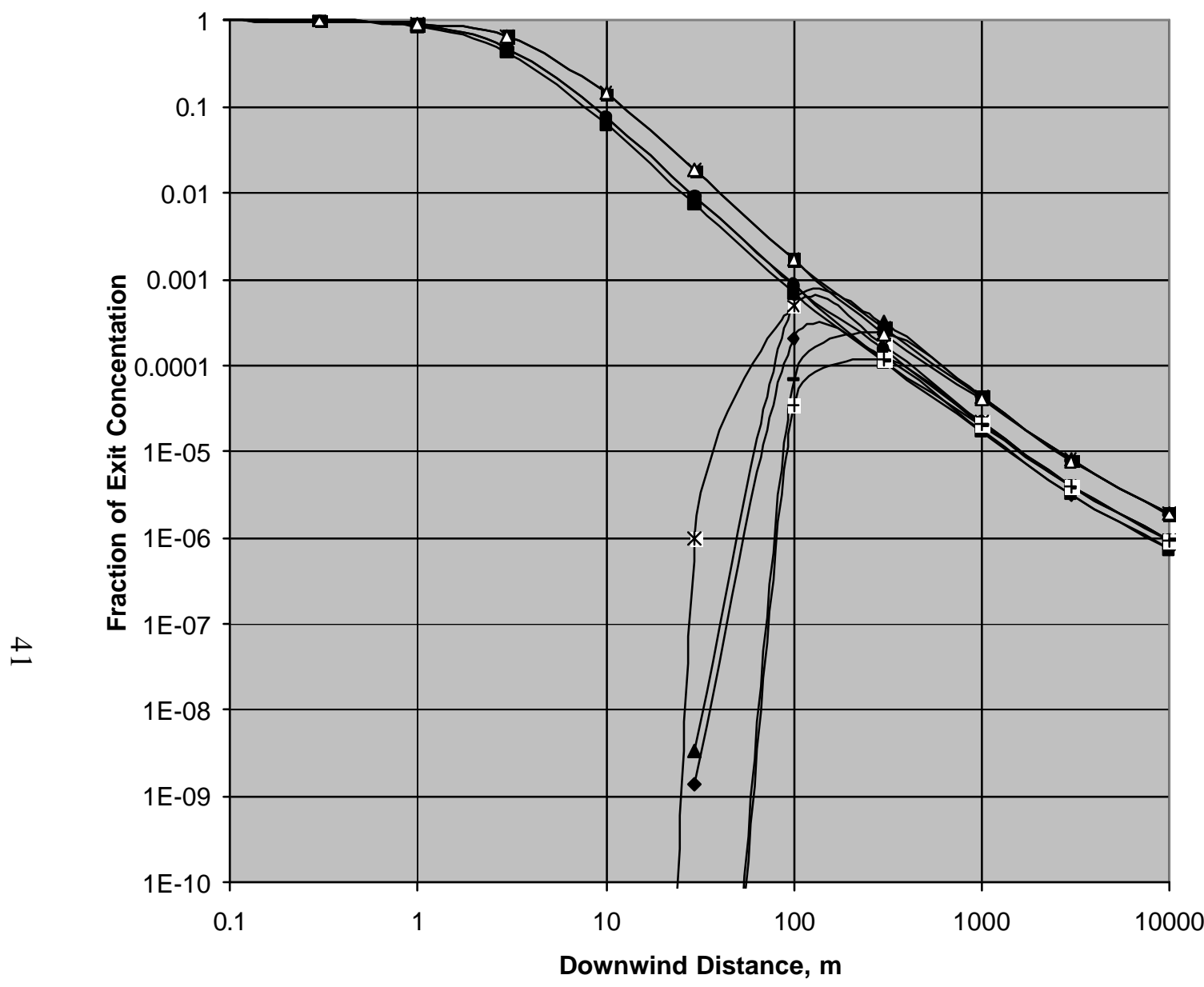

$\bullet$ AP Farm W/ Extension (LF), Stability $E$ at $\mathrm{U}=10 \mathrm{~m} / \mathrm{s}$, Ground Level

- AP Farm W/ Extension (LF), Stability E at $\mathrm{U}=10 \mathrm{~m} / \mathrm{s}$, Plume Centerline

- AP Farm W/ Extension (HF), Stability E at $U=10 \mathrm{~m} / \mathrm{s}$, Ground Level

$\rightarrow$ AP Farm W/ Extension (HF), Stability E at $U=10 \mathrm{~m} / \mathrm{s}$, Plume Centerline

-*-AW Farm Existing Vent, Stability E at $\mathrm{U}=10 \mathrm{~m} / \mathrm{s}$, Ground Level

- AW Farm Existing Vent, Stability E at $U=10 \mathrm{~m} / \mathrm{s}$, Plume Centerline

--AW Farm W-314 (LF), Stability E at $\mathrm{U}=10 \mathrm{~m} / \mathrm{s}$, Ground Level

-AW Farm W-314 (LF), Stability E at $\mathrm{U}=10 \mathrm{~m} / \mathrm{s}$, Plume Centerline

- AW Farm W-314 (HF), Stability E at $\mathrm{U}=10 \mathrm{~m} / \mathrm{s}$, Ground Level

$\triangle$ AW Farm W-314 (HF), Stability E at $\mathrm{U}=10 \mathrm{~m} / \mathrm{s}$, Plume Centerline

Figure 30. Fractional Air Concentrations under Stable High-Wind Speed Conditions: AP and AW Tank Farm Vents 


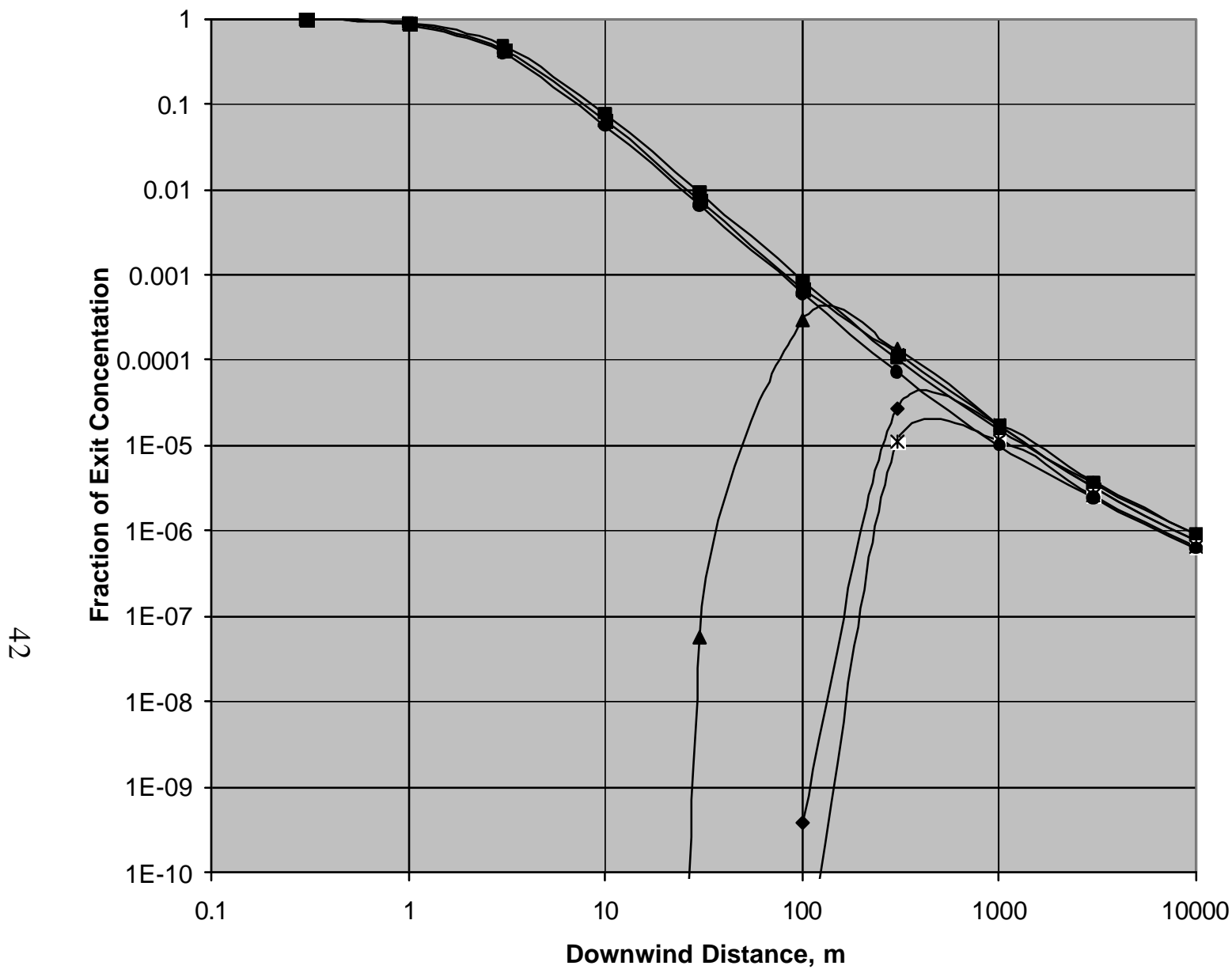
$\longrightarrow$ AY/AZ Existing Vent, Stability E at $\mathrm{U}=10 \mathrm{~m} / \mathrm{s}$, Ground Level
$\rightarrow-A Y / A Z$ Existing Vent, Stability $E$ at $\mathrm{U}=10 \mathrm{~m} / \mathrm{s}$, Plume Centerline
ـ SY Farm Existing Vent, Stability E at $\mathrm{U}=10 \mathrm{~m} / \mathrm{s}$, Ground Level
- - SY Farm Existing Vent, Stability E at $\mathrm{U}=10 \mathrm{~m} / \mathrm{s}$, Plume Centerline
- - 242 A Evaporator Stack, Stability E at $\mathrm{U}=10 \mathrm{~m} / \mathrm{s}$, Ground Level
$\rightarrow-242$ A Evaporator Stack, Stability E at $\mathrm{U}=10 \mathrm{~m} / \mathrm{s}$, Plume Centerline

Figure 31. Fractional Air Concentrations under Stable High-Wind Speed Conditions: AY/AZ, SY Tank Farms and 242 A Evaporator Stack 


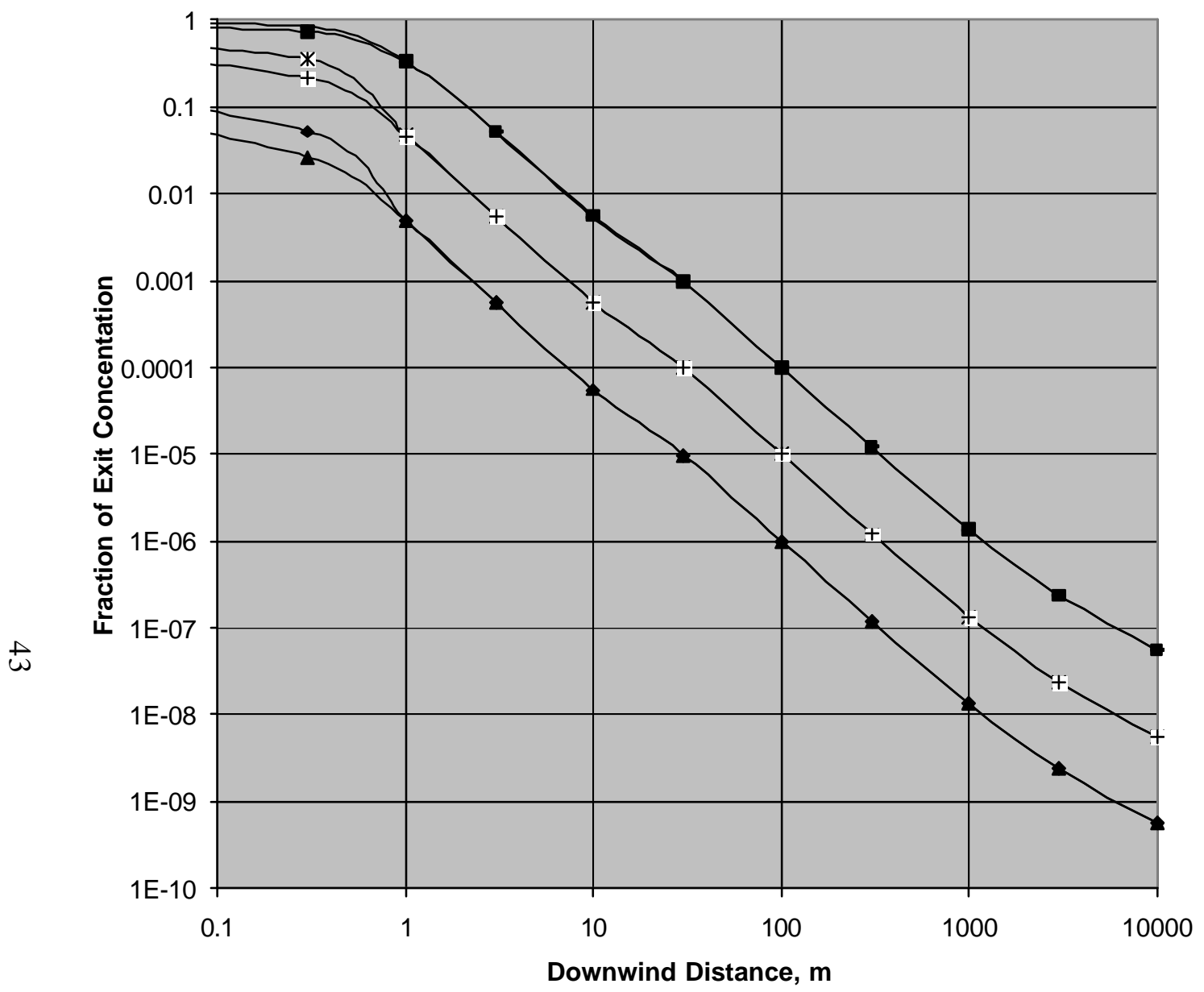
$\rightarrow-4$ Inch Pipe (Near surface), Stability $E$ at $\mathrm{U}=10 \mathrm{~m} / \mathrm{s}, E=1 \mathrm{~m} 3 / \mathrm{hr}$ Plume Centerline
$\rightarrow$ Near Surface Box Filter Vent, Stability E at $\mathrm{U}=10 \mathrm{~m} / \mathrm{s}, \mathrm{E}=1 \mathrm{~m} 3 / \mathrm{hr}$ Plume Centerline
- - 4 Inch Pipe (Near surface), Stability E at $\mathrm{U}=10 \mathrm{~m} / \mathrm{s}, \mathrm{E}=10 \mathrm{~m} 3 / \mathrm{hr}$ Plume Centerline
- - Near Surface Box Filter Vent, Stability E at $\mathrm{U}=10 \mathrm{~m} / \mathrm{s}, \mathrm{E}=10 \mathrm{~m} 3 / \mathrm{hr}$ Plume Centerline
- 4 Inch Pipe (Near surface), Stability E at $\mathrm{U}=10 \mathrm{~m} / \mathrm{s}, \mathrm{E}=100 \mathrm{~m} 3 / \mathrm{hr}$ Plume Centerline
- Near Surface Box Filter Vent, Stability E at $\mathrm{U}=10 \mathrm{~m} / \mathrm{s}, \mathrm{E}=100 \mathrm{~m} 3 / \mathrm{hr}$ Plume Centerline

Figure 32. Fractional Air Concentrations under Stable High-Wind Speed Conditions: Near-Surface Passive Vents 


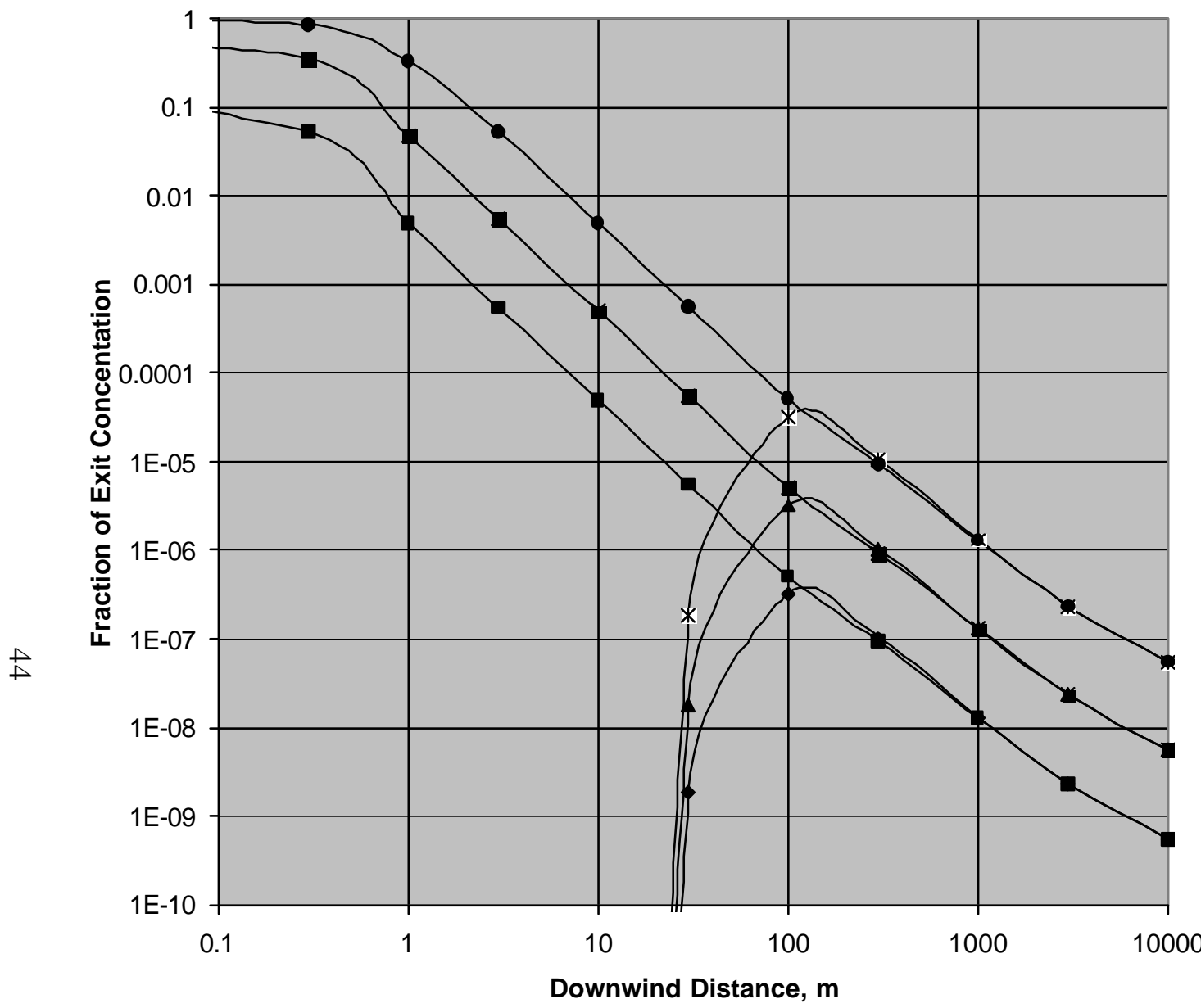

$\checkmark 4$ Inch Pipe (Stack), Stability E at $U=10 \mathrm{~m} / \mathrm{s}$, $\mathrm{E}=1 \mathrm{~m} 3 / \mathrm{hr}$, Ground Level

$\rightarrow-4$ Inch Pipe (Stack), Stability $E$ at $U=10 \mathrm{~m} / \mathrm{s}$, $\mathrm{E}=1 \mathrm{~m} 3 / \mathrm{hr}$, Plume Centerline

$\leftarrow 4$ Inch Pipe (Stack), Stability $E$ at $U=10 \mathrm{~m} / \mathrm{s}$, $\mathrm{E}=10 \mathrm{~m} 3 / \mathrm{hr}$, Ground Level

-4 Inch Pipe (Stack), Stability $E$ at $U=10 \mathrm{~m} / \mathrm{s}$, $\mathrm{E}=10 \mathrm{~m} 3 / \mathrm{hr}$, Plume Centerline

$-*-4$ Inch Pipe (Stack), Stability $E$ at $U=10 \mathrm{~m} / \mathrm{s}$, $\mathrm{E}=100 \mathrm{~m} 3 / \mathrm{hr}$, Ground Level

$\longrightarrow-4$ Inch Pipe (Stack), Stability E at $U=10 \mathrm{~m} / \mathrm{s}$, $\mathrm{E}=100 \mathrm{~m} 3 / \mathrm{hr}$, Plume Centerline

Figure 33. Fractional Air Concentrations under Stable High-Wind Speed Conditions: Passively Vented Stack 


\subsection{Plume Widths}

For the peak outdoor vapor concentrations to be on the order of headspace vapor concentrations, the air released from the headspace will have to be relatively undiluted. This constraint dictates a size of such peak concentration occurrences. Table 5 gives an idea of how the width of such a plume compares with the downwind arcs covering 90 degrees. The plots in the previous section show that such peak concentrations are unlikely to reach the larger distances shown in this table. For the average exposure, the percentages initially decrease but then tend to become constant with distance. 
Table 5. Plume Widths Expressed as Percentage of a 90-Degree Downwind Sector

\begin{tabular}{|c|c|c|c|c|c|c|c|c|}
\hline \multirow{2}{*}{$\begin{array}{c}\text { Exposure } \\
\text { Type }\end{array}$} & \multirow[b]{2}{*}{ Stack/Vent } & \multicolumn{7}{|c|}{ Downwind Distance, $\mathrm{m}$} \\
\hline & & $1(\%)$ & $3(\%)$ & $10(\%)$ & $30(\%)$ & $100(\%)$ & $300(\%)$ & $1000(\%)$ \\
\hline \multirow{14}{*}{ Peak } & AN Farm Existing Vent & 4.0 & 1.3 & 0.40 & 0.135 & 0.040 & 0.013 & 0.004 \\
\hline & AN Farm W-314 & 4.0 & 1.3 & 0.40 & 0.135 & 0.040 & 0.013 & 0.004 \\
\hline & AP Farm W/ Extension & 2.4 & 0.8 & 0.24 & 0.081 & 0.024 & 0.008 & 0.002 \\
\hline & AW Farm Existing Vent & 4.0 & 1.3 & 0.40 & 0.135 & 0.040 & 0.013 & 0.004 \\
\hline & AW Farm W-314 & 2.0 & 0.7 & 0.20 & 0.067 & 0.020 & 0.007 & 0.002 \\
\hline & \begin{tabular}{|l|} 
AY/AZ Existing Vent \\
\end{tabular} & 4.2 & 1.4 & 0.42 & 0.140 & 0.042 & 0.014 & 0.004 \\
\hline & SY Farm Existing Vent & 2.4 & 0.8 & 0.24 & 0.081 & 0.024 & 0.008 & 0.002 \\
\hline & 242A Evaporator Stack & 3.2 & 1.1 & 0.32 & 0.108 & 0.032 & 0.011 & 0.003 \\
\hline & 4-Inch Pipe (Near-Surface) & 1.6 & 0.5 & 0.16 & 0.054 & 0.016 & 0.005 & 0.002 \\
\hline & Near-Surface Box Filter Vent & 4.6 & 1.5 & 0.46 & 0.155 & 0.046 & 0.015 & 0.005 \\
\hline & 4-Inch Pipe (Stack) & 1.6 & 0.5 & 0.16 & 0.054 & 0.016 & 0.005 & 0.002 \\
\hline & AY/AZ Existing Vent & 4.2 & 1.4 & 0.42 & 0.140 & 0.042 & 0.014 & 0.004 \\
\hline & 4-Inch Pipe (Stack) & 1.6 & 0.5 & 0.16 & 0.054 & 0.016 & 0.005 & 0.002 \\
\hline & 4-Inch Pipe (Stack) & 1.6 & 0.5 & 0.16 & 0.054 & 0.016 & 0.005 & 0.002 \\
\hline \multirow{7}{*}{ Average } & 4-Inch vent - A Stability & 6.6 & 6.4 & 6.4 & 6.4 & 6.4 & 6.4 & 6.4 \\
\hline & 4-Inch vent - B Stability & 4.1 & 3.9 & 3.8 & 3.8 & 3.8 & 3.8 & 3.8 \\
\hline & 4-Inch vent - C Stability & 3.0 & 2.6 & 2.5 & 2.5 & 2.5 & 2.5 & 2.3 \\
\hline & 4-Inch vent - D Stability & 2.5 & 2.0 & 1.9 & 1.9 & 1.8 & 1.6 & 1.2 \\
\hline & 4-Inch vent - E Stability & 1.9 & 1.1 & 1.0 & 0.9 & 0.9 & 0.9 & 0.7 \\
\hline & 4-Inch vent - F Stability & 1.7 & 0.7 & 0.5 & 0.5 & 0.5 & 0.5 & 0.4 \\
\hline & 4-Inch vent - G Stability & 1.6 & 0.6 & 0.3 & 0.3 & 0.3 & 0.2 & 0.2 \\
\hline
\end{tabular}




\subsection{Additional Release and Dispersion Processes}

Additional release and dispersion processes can potentially influence the concentrations of vapors in the plumes of headspace air with in the breathing zone around the tanks. The above analysis considers the releases through vents and stacks using standard single-release dispersion modeling. In this section, external processes that may combine or modify the resulting plumes of headspace air are considered.

\subsection{Plume Combination}

Under certain conditions, the single vent/stack releases considered above could potentially combine and thus increase the average concentrations. The above results show that for the majority of conditions, the plumes of headspace air are dispersed so quickly that the additive effect to another plume downwind will be negligible.

For all potential combinations of plumes of headspace air, the peak concentrations in the combined plume still will be limited by the maximum headspace concentrations that are being vented. That limit exists because if two plumes were mixed together with no ambient air, the concentration of the combined plume will be the average of the two plumes. That is, with no ambient mixing the resulting concentration is the average of the two concentrations - and the average is never larger than either one:

$$
\mathrm{C}_{\mathrm{c}}=\left(\mathrm{C}_{1}+\mathrm{C}_{2}\right) / 2.0
$$

In reality, the plumes will be mixed with ambient air. The air concentration in the plume will depend on the extent of mixing of the plume with ambient air. The effect of plume combinations can be illustrated by considering effective dilution volumes for the plumes. The combined plume concentration for release from point 1 that with the downwind release from point 2 is given by:

$$
\mathrm{Cc}=\mathrm{C} 1 \mathrm{~d} 1+\mathrm{C} 2 \mathrm{~d} 2 \mathrm{~d} 1(\mathrm{~V} 2 \mathrm{a} / \mathrm{V} 2 \mathrm{i})
$$

Where $\mathrm{Cc}=$ the combined plume concentration of a selected chemical

$\mathrm{C}_{1}$ and $\mathrm{C}_{2}$ are the initial concentrations in plumes from release points 1 and 2 respectively, $\mathrm{d}_{1}$ and $\mathrm{d}_{2}$ are the dilution rates with a range of 0 to 1 and equal to 1 at the point of release, $\mathrm{V}_{2} \mathrm{i}$ is the effective initial mixing volume from point 2 for a selected averaging time, and $\mathrm{V}_{2 \mathrm{a}}$ is the effective ambient air mixing volume for the plume from point 2.

At release point $2, \mathrm{~V} 2 \mathrm{a}$ is equal to zero and $\mathrm{d} 2=1$ by definition such that:

$$
\mathrm{C}_{\mathrm{c}}=\mathrm{C}_{1}
$$

As plume 2 mixes with ambient air that includes the dispersed headspace air from release point 1, the resulting concentration can be larger than for plume 1 alone. 
As the value of $V_{2 a}$ increases at progressively greater downwind distances, the ratio $V_{2 i} / V_{2 a}$ approaches $d_{1}$. Thus at distances where both plumes have undergone significant dilution, the concentration will simply be the sum of the contributions of the two plumes:

$$
\mathrm{C}_{\mathrm{c}}=\left(\mathrm{C}_{1} \mathrm{~d}_{1}+\mathrm{C}_{2} \mathrm{~d}_{2}\right)
$$

For the double-shell tanks there is a single stack release (either through a primary or secondary stack). The stacks for the different double-shell tanks are sufficiently far apart such that the combination of plumes will occur only infrequently; a very steady wind direction aligned directly with the stacks is required to superimpose the plumes. Even if this does occur on rare occasions for the plumes from two stacks, the peak concentrations will still be limited by the maximum headspace concentrations. Assuming the two plumes have the same initial concentrations, the downwind average concentrations of vapor in the combined plume can be increased up to a factor of two (Equation 5). If the release concentration in one of the plumes is greater than the other, then the increase will be less than a factor of two.

For the single-shell tanks, the tank vents are located in relatively close proximity, often along a line. This configuration means that their plumes will be expected to combine at relatively short travel distances. This combination of plumes will not be important for the majority of conditions where there is relatively rapid dispersal of the vented headspace air. However, for conditions with limited dispersion, the average plumes downwind will increase by some factor (up to the number of vent plumes that are combined). That is, if six vent plumes combine, the average downwind dispersed concentrations in the plumes can be up to a maximum of six times greater. Near the releases the direction of the wind will be important in determining if the plumes first combine at short distances (i.e., the separation distance of the vents) or at some extended distance when the plumes are sufficiently dispersed so to be wide enough to combine. In any case, the peak concentrations in the combined plume will be limited by the maximum headspace concentrations that are being vented.

The limit of cumulative concentrations cannot be approached at or near a release vent. The plumes will be additive only at downwind distances that are large compared to the distance between the two releases. And the cumulative concentration will last only as long as the wind direction continues to superimpose the average position of the plumes.

\subsection{Local Surface Roughness}

The existence of surface roughness elements on the surface area of a tank farm with heights that are as high as, or higher than, the release vents will influence the plume of headspace air within the breathing space. Such surface roughness at the various tank farms shows considerable variation - from relatively unobstructed surface area with only vents to surface areas covered with various equipment and structures. Although little effect is expected on the dispersion of stack plumes (because of their elevated exit location relative to the roughness heights), an effect of surface roughness is expected as the result of mechanically generated local turbulence. This effect on the dispersion of plumes from near-surface vents will occur only under non-calm conditions. 
The effect of an increase in roughness will be faster dilution rates for near-surface releases under noncalm conditions. Tanks farms with many structures around near-surface vents will be expected to have lower average concentrations. Even within tank farms there is enough variation in the surface roughness that the dispersion will vary between different vent locations within a tank farm. The dispersion curves given above assume a relatively smooth surface area with only exhaust vents. That analysis is conservative in that credit is not taken for the various wake effects of structures surrounding the nearsurface vents.

Potential peak concentrations will remain the same regardless of surface roughness; i.e., they are limited by the maximum headspace concentrations. However, as noted above, greater surface roughness will tend to decrease the average concentrations.

\subsection{Interconnected Passively Vented Tanks}

The various mechanisms for passive tank venting result in a range of observed venting rates for the different tanks. It is likely that the interconnected tanks have higher ventilation rates as a result of these interconnections. This means that for the interconnected tanks, one vent may have inflow and another have outflow - with the headspace air from several tanks being vented from a single vent. The range of venting rates considered in the above analysis covers this possibility of enhanced ventilation from certain stacks.

\subsection{Non-Vent Releases}

Not all venting from the tanks occurs though the vents. This situation is particularly true for the passively vented single-shell tanks that only have one vent per tank (i.e., not interconnected with other tanks). For venting to occur there needs to be an inflow and outflow. Given the very small observed ventilation rates, very small leaks through cracks and entry points can be important potential venting locations.

The nature of the plume will be much the same no matter where the releases occur. The single-shell tank vents are near the ground and all the leak points will also be near the ground. The peak concentrations still will be determined by the headspace concentration and the plume persistence determined by the volume of headspace air that is released. The one difference is that if the outflow is through multiple points (crack, pipes, etc.), there will be multiple plumes with smaller volumes. Thus no matter exactly where the material exits, the dispersion curves given above for a range of ventilation rates are expected to be a reasonable representation of the surface releases from the tanks.

Releases through enclosures such as electrical panels represent a case where the released materials from the tank may be held up. If there is an exchange with outdoor air, the concentration in the enclosure will be less than the headspace concentrations. If the enclosure is relatively well-sealed (or air flows only out the enclosure), the concentrations are expected to be at, or near, the headspace concentrations. Release of the air in such a panel over a short period is considered a puff release. If the volume of material in a puff from an enclosure is $1 \mathrm{~m}^{3}$, then this volume of air is less than the average volume of air per hour observed coming from a well-sealed tank (Huckaby et al. 1997; Huckaby et al. 1998). A puff experiences dilution along the axis of travel in addition to the vertical and lateral dispersion that a continuous release 
experiences. As a result, under otherwise equivalent conditions, a puff release will be diluted faster than the continuous plumes.

\subsection{Plume Pooling}

Local surface pooling of the releases from the tank headspaces has been suggested as a possibility. The above analysis shows the volumes of released air are too small for buoyancy to be a factor in the fate of the plumes. Thus the releases from the tank vents and stacks will, for all practical purposes, move passively with the local air.

This observation leaves the possibility open that the released headspace air may be trapped in surface pools of cool air. If a vent is located in an area where surface pooling of air is occurring, then the released headspace air also can be become part of the pooled air.

Surface pooling of air occurs under meteorological conditions with strong surface cooling (i.e., clear sky and nocturnal conditions) combined with low wind speeds. Pockets of cool air can reside for periods of time in natural depressions in the local topography. The fact that the Hanford Site tank farms are located on the top or side of a plateau minimizes but does not eliminate the possibility of having tank farms where pooling of air may occur. Pooling of the air from the tank headspaces can only occur when: 1) a closed depression in the local topography containing the vent exists, 2) winds are calm, 3) there is strong surface cooling, and 4) there is sufficient venting of the tanks.

Although the HMS (Hoitink 2004) provides guidance on the general frequency of calms on the top of the plateau where the Hanford Site underground tanks are located, the existence of calm conditions at a specific tank farm is highly dependent on local influences. All the tank farm areas are graded to be level and many are at least partly enclosed by an elevated bank of earth. The banks have heights that typically extend above the breathing zone. Only for a tank farm completely surrounded by these banks or higher local topography on all sides is the exit flow of cool near-surface air blocked so that pooling may occur. For other tanks, if any slope exists in the terrain surrounding a tank farm, the denser cool air at the surface will generate a local circulation and pooling will not occur.

As part of this study each farm was visually evaluated for the existence of an area when the vented tank headspace vapors could be potentially held in a pool of cool ambient air that could extend up to the breathing zone. Cool air with its slightly higher density flows much like water. If any slope or opening exits to a lower elevation, the cooler air will flow down the slope and out the opening. Thus only when there is raised terrain all the way around a tank farm, is that area a candidate for significant surface pooling of air. Our visual inspection indicated that the terrain requirements for local pooling of air did not exist at the majority of the tank farms. A few tank farms appear as if they may have the potential of pooling, but that was not confirmed in the evaluation.

All the double-shell tanks have forced-air stack vents above the breathing zone and thus cannot have their releases trapped in surface pooling of air. For the single-shell tanks, their near-surface vents are in the breathing zone for the tanks. 
What will happen if releases are trapped in a surface pooling of air within the breathing area? The volume of headspace air being released along with the duration defines how much headspace can potentially be held in a topographical depression. In all cases the peak concentration within the depression will be limited by the maximum headspace concentration. The duration of pooling will depend on the local weather conditions and can be less than an hour to a number of hours in duration. When the pooling event ends, the pooled air will become a release of the headspace air.

What does this mean in terms of the Hanford Site tank farms? A key factor is how much venting is expected during occurrence of such an event. Droppo (2004) indicates that a combination of wind, temperature, and pressure influences control the ventilation rates of the passively ventilated tanks. For Tank U103, wind has by far the greatest influence. Because pooling only occurs at very low or calm winds, wind-driven ventilation and pooling are mutually exclusive events. Likewise, large pressure changes are normally associated with winds, making local pooling of air very unlikely during significant pressure-driven venting. Thus small diurnal pressure changes and the thermal difference between the tank headspace and outdoor air are the only mechanisms that can potentially lead to releases during pooling events. The plume rise analysis showed that the pooling conditions (low wind and stable conditions) are the only case where the warmer air results in a slight positive increase in the effective plume height. For Tank U103 the release rates from these processes are typically 1 or $2 \mathrm{~m}^{3} /$ hour (Droppo 2004). For a 5-hour period, 5 to $10 \mathrm{~m}^{3}$ is released, which is a very small fraction of the typical volumes of the breathing space over the tank farms. This large difference in volumes means that the tank headspace air releases are too small to significantly increase the average concentration in the breathing zone under pooling conditions. If pooling occurs, the near-field portion of the dispersion curves shown in Figure 18 are representative of what is expected with the plume effectively trapped in a topographical depression. The distance axis approximately represents travel at some low wind speed (e.g., $1 \mathrm{~m} / \mathrm{s}$ ) within the pooling volume. The average concentrations in the breathing zone will increase with time and approach some average value on the order of 0.0003 of the headspace concentrations after 5 hours of pooling (based on $10 \mathrm{~m}^{3}$ tank air released into a $30,000 \mathrm{~m}^{3}$ pooling volume). This estimate will increase by the number of vents in the tank farm. The peak concentration will be the concentration that will be encountered in manner indicated by Figure 18.

In summary, a characterization of surface-air pooling events at the tank farms is provided. Stack releases are at a sufficiently high height that they will not contribute to pooling events. Our analysis shows that direct pooling driven by the thermal plume properties of the headspace air alone will not occur. However, the possibility of ambient air pooling within the breathing space is considered. The relative small volumes of headspace air released into such a pool of air makes it very unlikely that the average concentrations in the breathing zone will approach the levels of headspace concentrations but the probability of short-duration encounters with peak concentrations will increase. 


\subsection{Conclusions}

There is little possibility of significant plume rise for any of the tank releases of headspace air. In terms of the downwind concentration profiles, there is a consistency within the results for the two types of releases: forced-air stack and passive vent tanks. The passive stack vent is much like the forced-air stacks.

For stack releases, both plume centerline and ground-level concentration results are presented. The ground-level concentrations are the predicted averages for the breathing zone. The plume centerline concentrations will normally travel above the breathing zone. Under special conditions, such as fumigation, these plumes may be carried down into the breathing zone. Also, the stack plume may intersect locations on surrounding local terrain that is as high as, or higher than, the effective plume height. The touchdown point for the stack plumes (i.e., the point where the plume disperses sufficiently to extend down to the ground) consistently occurs when the average concentration will have been reduced by at least 3 or 4 orders of magnitude.

For surface releases, the volume of air involved is small. If a person is exposed to a high concentration it will be only for a short duration, given the small volume that will need to be maintained for such occurrences.

The surface roughness at the various tank farms varies from relatively smooth (only vents) to rough (air flow obstructed by various equipment and structures). The analysis conducted here conservatively assumes the relatively smooth condition. The surface roughness will be a factor only for the releases at a height equiva lent to the heights of the roughness elements. For the passive near-surface vents, the tank farm areas with significant roughness elements will have increased dilution rates. The result will be that the average concentrations will decrease faster than for the smoother area considered in this analysis.

Plume pooling will not occur as a result of the thermal properties of the released headspace air. If the released air is incorporated in pooling of air around the tank farm, the small volumes of the release greatly limits any potential impacts.

The combination of plumes from different vents will not increase the potential peak exposures but can if the plumes merge increase in an approximately additive fashion the average plume vapor concentrations.

The results of the tank plume analysis provide insights into what can and cannot be expected. Occasional short duration exposures of up to several seconds to relatively undiluted headspace air can be expected in the immediate vicinity of the tank vents. Average concentrations that represent diffusion, as well as spatial averaging, fall off rapidly with distance for the passive vents and to a lesser extent for the forcedair stacks. The addition of the influence of the surface roughness elements on the tank farms will increase the rate at which concentration will decrease with distance. 


\subsection{References}

Briggs GA. 1973. Diffusion Estimation for Small Emissions. NOAA Atmospheric Turbulence and Diffusion Laboratory, Contribution File No. 79. Oak Ridge Tennessee.

U.S. Environmental Protection Agency, Office of Research and Development, National Center for Environmental Assessment, U.S. Environmental Protection Agency, Washington, DC.

Droppo, JG, Jr. 2004. Testing IH Instrumentation: Analysis of 1996-1998 Tank Ventilation Data in Terms of Characterizing a Transient Release. PNNL-14765, Pacific Northwest National Laboratory, Richland, Washington.

EPA. 1997. Volume I - General Factors Exposure Factors Handbook. EPA/600/P-95/002Fa,

Faurote JM and MJ Hocking. 2004. Meteorological Influences on Vapor Incidents in the 200 East and 200 West Tank Farms, From Calendar Years 2001 to 2004. CH2M HILL, Richland Washington.

Hoitink DJ, KW Burk, JV Ramsdell Jr., and WJ Shaw. 2004. Hanford Site Climatological Data Summary 2003 with Historical Data. PNNL-14616, Pacific Northwest National Laboratory, Richland, Washington.

Huckaby JL, KB Olsen, DS Sklarew, JC Evans, and KM Remund. 1997. Measurements of Waste Tank Passive Ventilation Rates Using Trace Gases. PNNL-11683, Pacific Northwest National Laboratory, Richland Washington.

Huckaby JL, JC Evans, DS Sklarew, and AV Mitroshkow. 1998. Waste Tank Ventilation Measured with a Tracer Gas Method. PNNL-11925, Pacific Northwest National Laboratory, Richland Washington.

Hunter CH. 2004a. Assessment of Occupational Exposure to Mercury Emissions from a Modified $2 H$ Evaporator Exhaust Stack. SRT-NTS-2004-00003, Inter-Office Memorandum, January 29, 2004, Westinghouse Savannah River Company, Aiken, South Carolina.

Hunter CH. 2004b. Assessment of Occupational Exposure to Mercury Emissions from Tank 50H. SRT-NTS-2004, Inter-Office Memorandum, March 8, 2004 -00005, Westinghouse Savannah River Company, Aiken, South Carolina.

Hunter CH. 2004c. Assessment of Occupational Exposure to Mercury Emissions from Tank 50H. SRT-NTS-2004-00009, Inter-Office Memorandum, April 20, 2004, Westinghouse Savannah River Company, Aiken, South Carolina.

Nickola, PW, JV Ramsdell, and JD Ludwock. 1970. Detailed Time-Histories Resulting from Puff and Short-Period Releases of Inert Radioactive Gas: A volume of Atmospheric Diffusion Data. BNWL1272, Pacific Northwest Laboratory, Richland, Washington. 
Ramsdell JV, Jr. and CA Simonen. 1997. Atmospheric Relative Concentrations in Building Wakes. NUREG/CR-6331, PNNL-10521 Rev. 1, Pacific Northwest National Laboratory, Richland, Washington.

Ramsdell JV and WT Hinds. 1969. Peak-to-Mean Concentration Ratios as a Function of Crosswind Position within the Mean Plume and the Ratio of the Duration of the Mean to the Duration off the Peak. Annual Report for 1968, to the US AEC Division of Biology and Medicine, Vol II, Physical Sciences, Part 1. Atmospheric Sciences, BNWL-1051, Pacific Northwest Laboratory, Richland, Washington.

Ramsdell JV. 1970a. Modeling Peak-to-Mean Concentration Ratios in Diffusing Plumes. Annual Report for 1969, to the US AEC Division of Biology and Medicine, Vol II, Physical Sciences, Part 1. Atmospheric Sciences, BNWL-1307, Pacific Northwest Laboratory, Richland, Washington.

Ramsdell JV. 1970b. "Concentration Fluctuation and Peak-to-Mean Concentration Ratios in Real Plumes." Proceedings of the Air Pollution, Turbulence, and Diffusion Symposium, Las Cruces, New Mexico, Dec. 7-10, 1971 by the American Meteorological Society, Boston, Massachusetts.

Ramsdell. JV. 1981. Hanford 200 East Area Ambient NO ${ }_{x}$ Concentrations February 1968 through February 1969. PNL-3996, Pacific Northwest Laboratory, Richland, Washington.

Ramsdell JV. 1982. Evaluation of Potential Releases from Single-Shell Tanks. PNL-8029, Pacific Northwest National Laboratory, Richland, Washington.

Ramsdell JV. 1989. "Building Wake Diffusion." Preprint Volume of the $6^{\text {th }}$ Joint Conference on Applications of Air Pollution Meteorology, Jan 30-Feb 3, Anaheim, California by the American Meteorological Society, Boston, Massachusetts.

Stam EC and G Crummal. 2002. ALRACT Demonstration for the Primary Ventilation Systems at the DST Tank Farms for the Interim Stabilization Project (Saltwell Pumping). RPP-9782, Rev. 0., U.S. Department of Energy Contract DE-AC27-1407, Richland, Washington.

Stock LM and JL Huckaby. 2000. "A Survey of Vapors in the Headspaces of Single-Shell Waste Tanks.” PNNL-13366, Pacific Northwest National Laboratory, Richland Washington. 


\section{Appendix A}

Forced-Air Stack Vents Fractional Concentrations 
Table A.1. AN Farm Existing Vent; Fractional Concentrations at Ground Level (GC) and Plume Centerline (CC)

\begin{tabular}{|c|c|c|c|c|c|c|c|c|c|c|c|c|c|c|}
\hline \multirow{2}{*}{$\begin{array}{c}\text { Stability } \\
\text { Class }\end{array}$} & \multirow{2}{*}{$\begin{array}{c}\text { Wind } \\
\text { Speed } \\
\mathbf{m} / \mathbf{s} \\
\end{array}$} & \multirow{2}{*}{$\begin{array}{c}\text { Venting } \\
\text { Rate } \\
\text { m3/hr }\end{array}$} & \multirow[b]{2}{*}{ Conc } & \multicolumn{3}{|c|}{ Distance Downwind, m } & \multirow[b]{2}{*}{3} & \multirow[b]{2}{*}{10} & \multirow[b]{2}{*}{30} & \multirow[b]{2}{*}{100} & \multirow[b]{2}{*}{300} & \multirow[b]{2}{*}{1000} & \multirow[b]{2}{*}{3000} & \multirow[b]{2}{*}{10,000} \\
\hline & & & & 0.001 & 0.3 & 1 & & & & & & & & \\
\hline A & 1 & 1019 & $\mathrm{GC}$ & $0.0 \mathrm{E}+00$ & $0.0 \mathrm{E}+00$ & $0.0 \mathrm{E}+00$ & $8.0 \mathrm{E}-10$ & $3.9 \mathrm{E}-03$ & $3.3 \mathrm{E}-03$ & 4.0E-04 & 4.6E-05 & 4.3E-06 & $5.2 \mathrm{E}-07$ & $5.8 \mathrm{E}-08$ \\
\hline $\mathrm{B}$ & 1 & 1019 & $\mathrm{GC}$ & $0.0 \mathrm{E}+00$ & $0.0 \mathrm{E}+00$ & $0.0 \mathrm{E}+00$ & $2.0 \mathrm{E}-24$ & $3.6 \mathrm{E}-04$ & $4.5 \mathrm{E}-03$ & 8.7E-04 & $1.0 \mathrm{E}-04$ & $9.8 \mathrm{E}-06$ & $1.2 \mathrm{E}-06$ & $1.3 \mathrm{E}-07$ \\
\hline $\mathrm{C}$ & 1 & 1019 & $\mathrm{GC}$ & $0.0 \mathrm{E}+00$ & $0.0 \mathrm{E}+00$ & $0.0 \mathrm{E}+00$ & $0.0 \mathrm{E}+00$ & $1.8 \mathrm{E}-06$ & 4.0E-03 & $1.7 \mathrm{E}-03$ & 2.3E-04 & $2.3 \mathrm{E}-05$ & $3.3 \mathrm{E}-06$ & $5.0 \mathrm{E}-07$ \\
\hline $\mathrm{D}$ & 1 & 1019 & GC & $0.0 \mathrm{E}+00$ & $0.0 \mathrm{E}+00$ & $0.0 \mathrm{E}+00$ & $0.0 \mathrm{E}+00$ & $5.1 \mathrm{E}-10$ & 2.3E-03 & $2.8 \mathrm{E}-03$ & $4.8 \mathrm{E}-04$ & $6.2 \mathrm{E}-05$ & $1.1 \mathrm{E}-05$ & $2.1 \mathrm{E}-06$ \\
\hline $\mathrm{E}$ & 1 & 1019 & GC & $0.0 \mathrm{E}+00$ & $0.0 \mathrm{E}+00$ & $0.0 \mathrm{E}+00$ & $0.0 \mathrm{E}+00$ & 7.2E-35 & 8.7E-06 & $3.0 \mathrm{E}-03$ & $1.0 \mathrm{E}-03$ & $1.3 \mathrm{E}-04$ & $2.4 \mathrm{E}-05$ & $5.7 \mathrm{E}-06$ \\
\hline $\mathrm{F}$ & 1 & 1019 & $\mathrm{GC}$ & $0.0 \mathrm{E}+00$ & $0.0 \mathrm{E}+00$ & $0.0 \mathrm{E}+00$ & $0.0 \mathrm{E}+00$ & $0.0 \mathrm{E}+00$ & $6.7 \mathrm{E}-15$ & 8.3E-04 & $2.0 \mathrm{E}-03$ & $3.6 \mathrm{E}-04$ & $6.7 \mathrm{E}-05$ & $1.6 \mathrm{E}-05$ \\
\hline $\mathrm{G}$ & 1 & 1019 & $\mathrm{GC}$ & $0.0 \mathrm{E}+00$ & $0.0 \mathrm{E}+00$ & $0.0 \mathrm{E}+00$ & $0.0 \mathrm{E}+00$ & $0.0 \mathrm{E}+00$ & $2.1 \mathrm{E}-48$ & $1.5 \mathrm{E}-06$ & $1.6 \mathrm{E}-03$ & $8.2 \mathrm{E}-04$ & $1.8 \mathrm{E}-04$ & 4.3E-05 \\
\hline A & 3.4 & 1019 & GC & $0.0 \mathrm{E}+00$ & $0.0 \mathrm{E}+00$ & $0.0 \mathrm{E}+00$ & $2.7 \mathrm{E}-10$ & $1.2 \mathrm{E}-03$ & $9.8 \mathrm{E}-04$ & $1.2 \mathrm{E}-04$ & $1.4 \mathrm{E}-05$ & $1.3 \mathrm{E}-06$ & $1.5 \mathrm{E}-07$ & $1.7 \mathrm{E}-08$ \\
\hline B & 3.4 & 1019 & GC & $0.0 \mathrm{E}+00$ & $0.0 \mathrm{E}+00$ & $0.0 \mathrm{E}+00$ & 7.6E-25 & $1.1 \mathrm{E}-04$ & $1.3 \mathrm{E}-03$ & $2.6 \mathrm{E}-04$ & $3.1 \mathrm{E}-05$ & 2.9E-06 & $3.5 \mathrm{E}-07$ & $3.9 \mathrm{E}-08$ \\
\hline $\mathrm{C}$ & 3.4 & 1019 & $\mathrm{GC}$ & $0.0 \mathrm{E}+00$ & $0.0 \mathrm{E}+00$ & $0.0 \mathrm{E}+00$ & $0.0 \mathrm{E}+00$ & $5.6 \mathrm{E}-07$ & $1.2 \mathrm{E}-03$ & 5.1E-04 & $6.8 \mathrm{E}-05$ & $6.9 \mathrm{E}-06$ & 9.7E-07 & $1.5 \mathrm{E}-07$ \\
\hline $\mathrm{D}$ & 3.4 & 1019 & $\mathrm{GC}$ & $0.0 \mathrm{E}+00$ & $0.0 \mathrm{E}+00$ & $0.0 \mathrm{E}+00$ & $0.0 \mathrm{E}+00$ & $1.7 \mathrm{E}-10$ & $7.0 \mathrm{E}-04$ & 8.3E-04 & $1.4 \mathrm{E}-04$ & $1.8 \mathrm{E}-05$ & $3.3 \mathrm{E}-06$ & $6.2 \mathrm{E}-07$ \\
\hline $\mathrm{E}$ & 3.4 & 1019 & $\mathrm{GC}$ & $0.0 \mathrm{E}+00$ & $0.0 \mathrm{E}+00$ & $0.0 \mathrm{E}+00$ & $0.0 \mathrm{E}+00$ & $2.8 \mathrm{E}-35$ & 2.7E-06 & 8.9E-04 & $3.1 \mathrm{E}-04$ & 3.9E-05 & 7.1E-06 & $1.7 \mathrm{E}-06$ \\
\hline $\mathrm{F}$ & 3.4 & 1019 & $\mathrm{GC}$ & $0.0 \mathrm{E}+00$ & $0.0 \mathrm{E}+00$ & $0.0 \mathrm{E}+00$ & $0.0 \mathrm{E}+00$ & $0.0 \mathrm{E}+00$ & $2.2 \mathrm{E}-15$ & $2.5 \mathrm{E}-04$ & 5.7E-04 & $1.0 \mathrm{E}-04$ & $2.0 \mathrm{E}-05$ & 4.7E-06 \\
\hline G & 3.4 & 1019 & GC & $0.0 \mathrm{E}+00$ & $0.0 \mathrm{E}+00$ & $0.0 \mathrm{E}+00$ & $0.0 \mathrm{E}+00$ & $0.0 \mathrm{E}+00$ & 8.0E-49 & 4.5E-07 & 4.7E-04 & $2.4 \mathrm{E}-04$ & $5.2 \mathrm{E}-05$ & $1.3 \mathrm{E}-05$ \\
\hline $\mathrm{C}$ & 10 & 1019 & $\mathrm{GC}$ & $0.0 \mathrm{E}+00$ & $0.0 \mathrm{E}+00$ & $0.0 \mathrm{E}+00$ & $0.0 \mathrm{E}+00$ & $2.0 \mathrm{E}-07$ & $4.1 \mathrm{E}-04$ & $1.7 \mathrm{E}-04$ & $2.3 \mathrm{E}-05$ & $2.3 \mathrm{E}-06$ & $3.3 \mathrm{E}-07$ & $5.0 \mathrm{E}-08$ \\
\hline D & 10 & 1019 & GC & $0.0 \mathrm{E}+00$ & $0.0 \mathrm{E}+00$ & $0.0 \mathrm{E}+00$ & $0.0 \mathrm{E}+00$ & $6.0 \mathrm{E}-11$ & $2.4 \mathrm{E}-04$ & $2.8 \mathrm{E}-04$ & $4.8 \mathrm{E}-05$ & $6.2 \mathrm{E}-06$ & $1.1 \mathrm{E}-06$ & $2.1 \mathrm{E}-07$ \\
\hline $\mathrm{E}$ & 10 & 1019 & GC & $0.0 \mathrm{E}+00$ & $0.0 \mathrm{E}+00$ & $0.0 \mathrm{E}+00$ & $0.0 \mathrm{E}+00$ & $1.0 \mathrm{E}-35$ & $9.2 \mathrm{E}-07$ & $3.0 \mathrm{E}-04$ & $1.0 \mathrm{E}-04$ & $1.3 \mathrm{E}-05$ & $2.4 \mathrm{E}-06$ & 5.7E-07 \\
\hline $\mathrm{C}$ & 20 & 1019 & $\mathrm{GC}$ & $0.0 \mathrm{E}+00$ & $0.0 \mathrm{E}+00$ & $0.0 \mathrm{E}+00$ & $0.0 \mathrm{E}+00$ & $9.8 \mathrm{E}-08$ & 2.0E-04 & 8.7E-05 & $1.2 \mathrm{E}-05$ & $1.2 \mathrm{E}-06$ & $1.6 \mathrm{E}-07$ & $2.5 \mathrm{E}-08$ \\
\hline $\mathrm{D}$ & 20 & 1019 & $\mathrm{GC}$ & $0.0 \mathrm{E}+00$ & $0.0 \mathrm{E}+00$ & $0.0 \mathrm{E}+00$ & $0.0 \mathrm{E}+00$ & $3.0 \mathrm{E}-11$ & $1.2 \mathrm{E}-04$ & $1.4 \mathrm{E}-04$ & $2.4 \mathrm{E}-05$ & $3.1 \mathrm{E}-06$ & $5.6 \mathrm{E}-07$ & $1.1 \mathrm{E}-07$ \\
\hline$E$ & 20 & 1019 & GC & $0.0 \mathrm{E}+00$ & $0.0 \mathrm{E}+00$ & $0.0 \mathrm{E}+00$ & $0.0 \mathrm{E}+00$ & $5.3 \mathrm{E}-36$ & 4.6E-07 & $1.5 \mathrm{E}-04$ & $5.2 \mathrm{E}-05$ & 6.7E-06 & $1.2 \mathrm{E}-06$ & $2.8 \mathrm{E}-07$ \\
\hline
\end{tabular}


Table A.1. ( contd)

\begin{tabular}{|c|c|c|c|c|c|c|c|c|c|c|c|c|c|c|}
\hline \multirow{2}{*}{$\begin{array}{c}\text { Stability } \\
\text { Class }\end{array}$} & \multirow{2}{*}{$\begin{array}{c}\text { Wind } \\
\text { Speed } \\
\mathrm{m} / \mathrm{s}\end{array}$} & \multirow{2}{*}{$\begin{array}{c}\text { Venting } \\
\text { Rate } \\
\text { m3/hr }\end{array}$} & \multirow[b]{2}{*}{ Conc } & \multicolumn{3}{|c|}{ Distance Downwind, m } & \multirow[b]{2}{*}{3} & \multirow[b]{2}{*}{10} & \multirow[b]{2}{*}{30} & \multirow[b]{2}{*}{100} & \multirow[b]{2}{*}{300} & \multirow[b]{2}{*}{1000} & \multirow[b]{2}{*}{3000} & \multirow[b]{2}{*}{10,000} \\
\hline & & & & 0.001 & 0.3 & 1 & & & & & & & & \\
\hline A & 1 & 1019 & $\mathrm{CC}$ & $1.0 \mathrm{E}+00$ & $9.6 \mathrm{E}-01$ & $6.7 \mathrm{E}-01$ & $1.9 \mathrm{E}-01$ & $2.0 \mathrm{E}-02$ & $2.9 \mathrm{E}-03$ & $3.9 \mathrm{E}-04$ & $4.6 \mathrm{E}-05$ & 4.3E-06 & $5.2 \mathrm{E}-07$ & $5.8 \mathrm{E}-08$ \\
\hline B & 1 & 1019 & $\mathrm{CC}$ & $1.0 \mathrm{E}+00$ & $9.8 \mathrm{E}-01$ & $8.2 \mathrm{E}-01$ & 3.4E-01 & $4.5 \mathrm{E}-02$ & $5.4 \mathrm{E}-03$ & $8.2 \mathrm{E}-04$ & $1.0 \mathrm{E}-04$ & $9.8 \mathrm{E}-06$ & $1.2 \mathrm{E}-06$ & $1.3 \mathrm{E}-07$ \\
\hline $\mathrm{C}$ & 1 & 1019 & $\mathrm{CC}$ & $1.0 \mathrm{E}+00$ & $9.9 \mathrm{E}-01$ & $9.1 \mathrm{E}-01$ & $5.3 \mathrm{E}-01$ & $9.3 \mathrm{E}-02$ & $1.1 \mathrm{E}-02$ & $1.5 \mathrm{E}-03$ & 2.3E-04 & 2.3E-05 & $3.3 \mathrm{E}-06$ & $5.0 \mathrm{E}-07$ \\
\hline $\mathrm{D}$ & 1 & 1019 & CC & $1.0 \mathrm{E}+00$ & $9.9 \mathrm{E}-01$ & $9.5 \mathrm{E}-01$ & $6.8 \mathrm{E}-01$ & $1.6 \mathrm{E}-01$ & $2.1 \mathrm{E}-02$ & $2.5 \mathrm{E}-03$ & $4.6 \mathrm{E}-04$ & $6.1 \mathrm{E}-05$ & $1.1 \mathrm{E}-05$ & $2.1 \mathrm{E}-06$ \\
\hline $\mathrm{E}$ & 1 & 1019 & $\mathrm{CC}$ & $1.0 \mathrm{E}+00$ & $1.0 \mathrm{E}+00$ & $9.8 \mathrm{E}-01$ & $8.5 \mathrm{E}-01$ & 3.3E-01 & 5.3E-02 & $5.2 \mathrm{E}-03$ & 9.3E-04 & $1.3 \mathrm{E}-04$ & $2.4 \mathrm{E}-05$ & $5.6 \mathrm{E}-06$ \\
\hline $\mathrm{F}$ & 1 & 1019 & $\mathrm{CC}$ & $1.0 \mathrm{E}+00$ & $1.0 \mathrm{E}+00$ & $9.9 \mathrm{E}-01$ & 9.4E-01 & 5.9E-01 & 1.4E-01 & 1.4E-02 & $1.9 \mathrm{E}-03$ & 3.3E-04 & $6.6 \mathrm{E}-05$ & $1.6 \mathrm{E}-05$ \\
\hline $\bar{G}$ & 1 & 1019 & $\mathrm{CC}$ & $1.0 \mathrm{E}+00$ & $1.0 \mathrm{E}+00$ & $1.0 \mathrm{E}+00$ & $9.8 \mathrm{E}-01$ & $8.0 \mathrm{E}-01$ & $3.1 \mathrm{E}-01$ & 3.9E-02 & $4.8 \mathrm{E}-03$ & $7.2 \mathrm{E}-04$ & $1.7 \mathrm{E}-04$ & 4.2E-05 \\
\hline A & 3.4 & 1019 & $\mathrm{CC}$ & $9.8 \mathrm{E}-01$ & $8.7 \mathrm{E}-01$ & $3.8 \mathrm{E}-01$ & $6.3 \mathrm{E}-02$ & $6.0 \mathrm{E}-03$ & $8.6 \mathrm{E}-04$ & $1.1 \mathrm{E}-04$ & $1.4 \mathrm{E}-05$ & $1.3 \mathrm{E}-06$ & $1.5 \mathrm{E}-07$ & $1.7 \mathrm{E}-08$ \\
\hline B & 3.4 & 1019 & $\mathrm{CC}$ & $9.9 \mathrm{E}-01$ & 9.4E-01 & $5.8 \mathrm{E}-01$ & $1.3 \mathrm{E}-01$ & $1.4 \mathrm{E}-02$ & $1.6 \mathrm{E}-03$ & 2.4E-04 & $3.1 \mathrm{E}-05$ & $2.9 \mathrm{E}-06$ & $3.5 \mathrm{E}-07$ & $3.9 \mathrm{E}-08$ \\
\hline $\mathrm{C}$ & 3.4 & 1019 & $\mathrm{CC}$ & $1.0 \mathrm{E}+00$ & 9.7E-01 & $7.5 \mathrm{E}-01$ & $2.5 \mathrm{E}-01$ & 2.9E-02 & $3.4 \mathrm{E}-03$ & 4.6E-04 & $6.7 \mathrm{E}-05$ & $6.9 \mathrm{E}-06$ & $9.6 \mathrm{E}-07$ & $1.5 \mathrm{E}-07$ \\
\hline $\mathrm{D}$ & 3.4 & 1019 & $\mathrm{CC}$ & $1.0 \mathrm{E}+00$ & $9.8 \mathrm{E}-01$ & $8.5 \mathrm{E}-01$ & $3.8 \mathrm{E}-01$ & 5.3E-02 & $6.2 \mathrm{E}-03$ & 7.4E-04 & $1.4 \mathrm{E}-04$ & $1.8 \mathrm{E}-05$ & $3.3 \mathrm{E}-06$ & $6.2 \mathrm{E}-07$ \\
\hline $\mathrm{E}$ & 3.4 & 1019 & CC & $1.0 \mathrm{E}+00$ & 9.9E-01 & 9.4E-01 & $6.2 \mathrm{E}-01$ & $1.3 \mathrm{E}-01$ & $1.6 \mathrm{E}-02$ & $1.5 \mathrm{E}-03$ & $2.8 \mathrm{E}-04$ & $3.9 \mathrm{E}-05$ & $7.0 \mathrm{E}-06$ & $1.7 \mathrm{E}-06$ \\
\hline$F$ & 3.4 & 1019 & $\mathrm{CC}$ & $1.0 \mathrm{E}+00$ & $9.9 \mathrm{E}-01$ & $9.8 \mathrm{E}-01$ & $8.2 \mathrm{E}-01$ & 2.9E-01 & $4.4 \mathrm{E}-02$ & $4.3 \mathrm{E}-03$ & 5.6E-04 & 9.9E-05 & $1.9 \mathrm{E}-05$ & $4.6 \mathrm{E}-06$ \\
\hline $\bar{G}$ & 3.4 & 1019 & $\mathrm{CC}$ & $1.0 \mathrm{E}+00$ & $9.9 \mathrm{E}-01$ & $9.9 \mathrm{E}-01$ & $9.3 \mathrm{E}-01$ & 5.4E-01 & $1.1 \mathrm{E}-01$ & $1.2 \mathrm{E}-02$ & $1.4 \mathrm{E}-03$ & $2.1 \mathrm{E}-04$ & $5.0 \mathrm{E}-05$ & $1.2 \mathrm{E}-05$ \\
\hline C & 10 & 1019 & $\mathrm{CC}$ & $9.9 \mathrm{E}-01$ & $9.2 \mathrm{E}-01$ & $5.1 \mathrm{E}-01$ & $1.0 \mathrm{E}-01$ & $1.0 \mathrm{E}-02$ & $1.1 \mathrm{E}-03$ & $1.5 \mathrm{E}-04$ & $2.3 \mathrm{E}-05$ & $2.3 \mathrm{E}-06$ & 3.3E-07 & $5.0 \mathrm{E}-08$ \\
\hline $\mathrm{D}$ & 10 & 1019 & $\mathrm{CC}$ & $9.9 \mathrm{E}-01$ & $9.5 \mathrm{E}-01$ & $6.5 \mathrm{E}-01$ & $1.7 \mathrm{E}-01$ & $1.9 \mathrm{E}-02$ & $2.1 \mathrm{E}-03$ & $2.5 \mathrm{E}-04$ & $4.6 \mathrm{E}-05$ & $6.1 \mathrm{E}-06$ & $1.1 \mathrm{E}-06$ & $2.1 \mathrm{E}-07$ \\
\hline $\bar{E}$ & 10 & 1019 & $\mathrm{CC}$ & $1.0 \mathrm{E}+00$ & $9.8 \mathrm{E}-01$ & $8.3 \mathrm{E}-01$ & $3.6 \mathrm{E}-01$ & $4.8 \mathrm{E}-02$ & $5.6 \mathrm{E}-03$ & $5.2 \mathrm{E}-04$ & $9.4 \mathrm{E}-05$ & 1.3E-05 & $2.4 \mathrm{E}-06$ & $5.6 \mathrm{E}-07$ \\
\hline $\mathrm{C}$ & 20 & 1019 & $\mathrm{CC}$ & $9.8 \mathrm{E}-01$ & $8.5 \mathrm{E}-01$ & $3.4 \mathrm{E}-01$ & $5.4 \mathrm{E}-02$ & $5.1 \mathrm{E}-03$ & 5.7E-04 & 7.7E-05 & $1.1 \mathrm{E}-05$ & $1.2 \mathrm{E}-06$ & $1.6 \mathrm{E}-07$ & $2.5 \mathrm{E}-08$ \\
\hline $\bar{D}$ & 20 & 1019 & $\mathrm{CC}$ & $9.9 \mathrm{E}-01$ & $9.1 \mathrm{E}-01$ & $4.8 \mathrm{E}-01$ & $9.5 \mathrm{E}-02$ & $9.4 \mathrm{E}-03$ & $1.1 \mathrm{E}-03$ & $1.3 \mathrm{E}-04$ & $2.3 \mathrm{E}-05$ & $3.1 \mathrm{E}-06$ & $5.6 \mathrm{E}-07$ & $1.1 \mathrm{E}-07$ \\
\hline E & 20 & 1019 & $\mathrm{CC}$ & $1.0 \mathrm{E}+00$ & $9.5 \mathrm{E}-01$ & 7.1E-01 & $2.2 \mathrm{E}-01$ & $2.5 \mathrm{E}-02$ & $2.8 \mathrm{E}-03$ & $2.6 \mathrm{E}-04$ & 4.7E-05 & $6.6 \mathrm{E}-06$ & $1.2 \mathrm{E}-06$ & $2.8 \mathrm{E}-07$ \\
\hline
\end{tabular}


Table A.2. AN Farm W-314; Fractional Concentrations at Ground Level (GC) and Plume Centerline (CC)

\begin{tabular}{|c|c|c|c|c|c|c|c|c|c|c|c|c|c|c|}
\hline \multirow{2}{*}{$\begin{array}{c}\text { Stability } \\
\text { Class }\end{array}$} & \multirow{2}{*}{$\begin{array}{c}\text { Wind } \\
\text { Speed } \\
\mathbf{m} / \mathbf{s}\end{array}$} & \multirow{2}{*}{$\begin{array}{c}\text { Venting } \\
\text { Rate } \\
\text { m3/hr }\end{array}$} & \multirow[b]{2}{*}{ Conc } & \multicolumn{3}{|c|}{ Distance Downwind, m } & \multirow[b]{2}{*}{3} & \multirow[b]{2}{*}{10} & \multirow[b]{2}{*}{30} & \multirow[b]{2}{*}{100} & \multirow[b]{2}{*}{300} & \multirow[b]{2}{*}{1000} & \multirow[b]{2}{*}{3000} & \multirow[b]{2}{*}{10,000} \\
\hline & & & & 0.001 & 0.3 & 1 & & & & & & & & \\
\hline $\mathrm{A}$ & 1 & 1699 & GC & $0.0 \mathrm{E}+00$ & $0.0 \mathrm{E}+00$ & $0.0 \mathrm{E}+00$ & $1.6 \mathrm{E}-35$ & $2.8 \mathrm{E}-05$ & $2.8 \mathrm{E}-03$ & $6.3 \mathrm{E}-04$ & $7.6 \mathrm{E}-05$ & $7.2 \mathrm{E}-06$ & $8.7 \mathrm{E}-07$ & $9.7 \mathrm{E}-08$ \\
\hline $\mathrm{B}$ & 1 & 1699 & $\mathrm{GC}$ & $0.0 \mathrm{E}+00$ & $0.0 \mathrm{E}+00$ & $0.0 \mathrm{E}+00$ & $0.0 \mathrm{E}+00$ & $2.0 \mathrm{E}-10$ & $1.2 \mathrm{E}-03$ & $1.2 \mathrm{E}-03$ & $1.7 \mathrm{E}-04$ & $1.6 \mathrm{E}-05$ & $2.0 \mathrm{E}-06$ & 2.2E-07 \\
\hline $\mathrm{C}$ & 1 & 1699 & GC & $0.0 \mathrm{E}+00$ & $0.0 \mathrm{E}+00$ & $0.0 \mathrm{E}+00$ & $0.0 \mathrm{E}+00$ & $7.3 \mathrm{E}-21$ & $1.4 \mathrm{E}-04$ & $1.9 \mathrm{E}-03$ & $3.7 \mathrm{E}-04$ & $3.9 \mathrm{E}-05$ & $5.5 \mathrm{E}-06$ & $8.4 \mathrm{E}-07$ \\
\hline $\mathrm{D}$ & 1 & 1699 & $\mathrm{GC}$ & $0.0 \mathrm{E}+00$ & $0.0 \mathrm{E}+00$ & $0.0 \mathrm{E}+00$ & $0.0 \mathrm{E}+00$ & $4.2 \mathrm{E}-36$ & $3.6 \mathrm{E}-06$ & $2.1 \mathrm{E}-03$ & 7.2E-04 & $1.0 \mathrm{E}-04$ & $1.8 \mathrm{E}-05$ & $3.5 \mathrm{E}-06$ \\
\hline $\mathrm{E}$ & 1 & 1699 & GC & $0.0 \mathrm{E}+00$ & $0.0 \mathrm{E}+00$ & $0.0 \mathrm{E}+00$ & $0.0 \mathrm{E}+00$ & $0.0 \mathrm{E}+00$ & $2.8 \mathrm{E}-17$ & $3.4 \mathrm{E}-04$ & $1.2 \mathrm{E}-03$ & $2.1 \mathrm{E}-04$ & $4.0 \mathrm{E}-05$ & $9.4 \mathrm{E}-06$ \\
\hline$F$ & 1 & 1699 & GC & $0.0 \mathrm{E}+00$ & $0.0 \mathrm{E}+00$ & $0.0 \mathrm{E}+00$ & $0.0 \mathrm{E}+00$ & $0.0 \mathrm{E}+00$ & $0.0 \mathrm{E}+00$ & $1.8 \mathrm{E}-07$ & $9.4 \mathrm{E}-04$ & $5.0 \mathrm{E}-04$ & $1.1 \mathrm{E}-04$ & $2.6 \mathrm{E}-05$ \\
\hline $\mathrm{G}$ & 1 & 1699 & GC & $0.0 \mathrm{E}+00$ & $0.0 \mathrm{E}+00$ & $0.0 \mathrm{E}+00$ & $0.0 \mathrm{E}+00$ & $0.0 \mathrm{E}+00$ & $0.0 \mathrm{E}+00$ & $5.0 \mathrm{E}-20$ & $4.7 \mathrm{E}-05$ & $7.7 \mathrm{E}-04$ & $2.6 \mathrm{E}-04$ & $6.8 \mathrm{E}-05$ \\
\hline $\mathrm{A}$ & 3.4 & 1699 & GC & $0.0 \mathrm{E}+00$ & $0.0 \mathrm{E}+00$ & $0.0 \mathrm{E}+00$ & $5.8 \mathrm{E}-36$ & $8.4 \mathrm{E}-06$ & 8.2E-04 & $1.8 \mathrm{E}-04$ & $2.2 \mathrm{E}-05$ & $2.1 \mathrm{E}-06$ & $2.5 \mathrm{E}-07$ & $2.8 \mathrm{E}-08$ \\
\hline B & 3.4 & 1699 & GC & $0.0 \mathrm{E}+00$ & $0.0 \mathrm{E}+00$ & $0.0 \mathrm{E}+00$ & $0.0 \mathrm{E}+00$ & $6.2 \mathrm{E}-11$ & $3.6 \mathrm{E}-04$ & $3.6 \mathrm{E}-04$ & $5.0 \mathrm{E}-05$ & $4.8 \mathrm{E}-06$ & $5.8 \mathrm{E}-07$ & $6.5 \mathrm{E}-08$ \\
\hline $\mathrm{C}$ & 3.4 & 1699 & GC & $0.0 \mathrm{E}+00$ & $0.0 \mathrm{E}+00$ & $0.0 \mathrm{E}+00$ & $0.0 \mathrm{E}+00$ & $2.4 \mathrm{E}-21$ & $4.1 \mathrm{E}-05$ & $5.7 \mathrm{E}-04$ & $1.1 \mathrm{E}-04$ & $1.1 \mathrm{E}-05$ & $1.6 \mathrm{E}-06$ & $2.5 \mathrm{E}-07$ \\
\hline $\mathrm{D}$ & 3.4 & 1699 & GC & $0.0 \mathrm{E}+00$ & $0.0 \mathrm{E}+00$ & $0.0 \mathrm{E}+00$ & $0.0 \mathrm{E}+00$ & $1.5 \mathrm{E}-36$ & $1.1 \mathrm{E}-06$ & $6.3 \mathrm{E}-04$ & $2.1 \mathrm{E}-04$ & $3.0 \mathrm{E}-05$ & $5.4 \mathrm{E}-06$ & $1.0 \mathrm{E}-06$ \\
\hline$E$ & 3.4 & 1699 & GC & $0.0 \mathrm{E}+00$ & $0.0 \mathrm{E}+00$ & $0.0 \mathrm{E}+00$ & $0.0 \mathrm{E}+00$ & $0.0 \mathrm{E}+00$ & $8.6 \mathrm{E}-18$ & $1.0 \mathrm{E}-04$ & $3.5 \mathrm{E}-04$ & $6.2 \mathrm{E}-05$ & $1.2 \mathrm{E}-05$ & $2.8 \mathrm{E}-06$ \\
\hline $\mathrm{F}$ & 3.4 & 1699 & GC & $0.0 \mathrm{E}+00$ & $0.0 \mathrm{E}+00$ & $0.0 \mathrm{E}+00$ & $0.0 \mathrm{E}+00$ & $0.0 \mathrm{E}+00$ & $0.0 \mathrm{E}+00$ & $5.5 \mathrm{E}-08$ & $2.8 \mathrm{E}-04$ & $1.5 \mathrm{E}-04$ & $3.1 \mathrm{E}-05$ & $7.6 \mathrm{E}-06$ \\
\hline $\mathrm{G}$ & 3.4 & 1699 & GC & $0.0 \mathrm{E}+00$ & $0.0 \mathrm{E}+00$ & $0.0 \mathrm{E}+00$ & $0.0 \mathrm{E}+00$ & $0.0 \mathrm{E}+00$ & $0.0 \mathrm{E}+00$ & $1.6 \mathrm{E}-20$ & $1.4 \mathrm{E}-05$ & 2.3E-04 & 7.6E-05 & $2.0 \mathrm{E}-05$ \\
\hline $\mathrm{C}$ & 10 & 1699 & GC & $0.0 \mathrm{E}+00$ & $0.0 \mathrm{E}+00$ & $0.0 \mathrm{E}+00$ & $0.0 \mathrm{E}+00$ & $8.4 \mathrm{E}-22$ & $1.4 \mathrm{E}-05$ & $1.9 \mathrm{E}-04$ & $3.7 \mathrm{E}-05$ & $3.9 \mathrm{E}-06$ & $5.5 \mathrm{E}-07$ & $8.4 \mathrm{E}-08$ \\
\hline $\mathrm{D}$ & 10 & 1699 & GC & $0.0 \mathrm{E}+00$ & $0.0 \mathrm{E}+00$ & $0.0 \mathrm{E}+00$ & $0.0 \mathrm{E}+00$ & $5.4 \mathrm{E}-37$ & $3.8 \mathrm{E}-07$ & $2.2 \mathrm{E}-04$ & 7.2E-05 & $1.0 \mathrm{E}-05$ & $1.8 \mathrm{E}-06$ & $3.5 \mathrm{E}-07$ \\
\hline$E$ & 10 & 1699 & $\mathrm{GC}$ & $0.0 \mathrm{E}+00$ & $0.0 \mathrm{E}+00$ & $0.0 \mathrm{E}+00$ & $0.0 \mathrm{E}+00$ & $0.0 \mathrm{E}+00$ & 3.0E-18 & $3.4 \mathrm{E}-05$ & $1.2 \mathrm{E}-04$ & $2.1 \mathrm{E}-05$ & 4.0E-06 & 9.4E-07 \\
\hline $\mathrm{C}$ & 20 & 1699 & GC & $0.0 \mathrm{E}+00$ & $0.0 \mathrm{E}+00$ & $0.0 \mathrm{E}+00$ & $0.0 \mathrm{E}+00$ & $4.3 \mathrm{E}-22$ & $7.0 \mathrm{E}-06$ & $9.7 \mathrm{E}-05$ & $1.9 \mathrm{E}-05$ & $1.9 \mathrm{E}-06$ & $2.7 \mathrm{E}-07$ & $4.2 \mathrm{E}-08$ \\
\hline $\mathrm{D}$ & 20 & 1699 & GC & $0.0 \mathrm{E}+00$ & $0.0 \mathrm{E}+00$ & $0.0 \mathrm{E}+00$ & $0.0 \mathrm{E}+00$ & $2.7 \mathrm{E}-37$ & $1.9 \mathrm{E}-07$ & $1.1 \mathrm{E}-04$ & $3.6 \mathrm{E}-05$ & $5.1 \mathrm{E}-06$ & 9.2E-07 & $1.8 \mathrm{E}-07$ \\
\hline $\mathrm{E}$ & 20 & 1699 & GC & $0.0 \mathrm{E}+00$ & $0.0 \mathrm{E}+00$ & $0.0 \mathrm{E}+00$ & $0.0 \mathrm{E}+00$ & $0.0 \mathrm{E}+00$ & $1.5 \mathrm{E}-18$ & $1.7 \mathrm{E}-05$ & $6.0 \mathrm{E}-05$ & $1.1 \mathrm{E}-05$ & $2.0 \mathrm{E}-06$ & 4.7E-07 \\
\hline
\end{tabular}


Table A.2. (contd)

\begin{tabular}{|c|c|c|c|c|c|c|c|c|c|c|c|c|c|c|}
\hline \multirow{2}{*}{$\begin{array}{c}\text { Stability } \\
\text { Class }\end{array}$} & \multirow{2}{*}{$\begin{array}{l}\text { Wind } \\
\text { Speed } \\
\mathrm{m} / \mathrm{s}\end{array}$} & \multirow{2}{*}{$\begin{array}{c}\text { Venting } \\
\text { Rate } \\
\text { m3/hr }\end{array}$} & \multirow[b]{2}{*}{ Conc } & \multicolumn{3}{|c|}{ Distance Downwind, $\mathbf{m}$} & \multirow[b]{2}{*}{3} & \multirow[b]{2}{*}{10} & \multirow[b]{2}{*}{30} & \multirow[b]{2}{*}{100} & \multirow[b]{2}{*}{300} & \multirow[b]{2}{*}{1000} & \multirow[b]{2}{*}{3000} & \multirow[b]{2}{*}{10,000} \\
\hline & & & & 0.001 & 0.3 & 1 & & & & & & & & \\
\hline A & 1 & 1699 & $\mathrm{CC}$ & $1.0 \mathrm{E}+00$ & $9.7 \mathrm{E}-01$ & 7.7E-01 & $2.8 \mathrm{E}-01$ & $3.3 \mathrm{E}-02$ & $3.9 \mathrm{E}-03$ & $5.8 \mathrm{E}-04$ & $7.5 \mathrm{E}-05$ & 7.1E-06 & $8.6 \mathrm{E}-07$ & 9.7E-08 \\
\hline B & 1 & 1699 & $\mathrm{CC}$ & $1.0 \mathrm{E}+00$ & $9.9 \mathrm{E}-01$ & $8.9 \mathrm{E}-01$ & 4.7E-01 & $7.3 \mathrm{E}-02$ & $8.6 \mathrm{E}-03$ & $1.1 \mathrm{E}-03$ & $1.7 \mathrm{E}-04$ & $1.6 \mathrm{E}-05$ & $2.0 \mathrm{E}-06$ & $2.2 \mathrm{E}-07$ \\
\hline $\mathrm{C}$ & 1 & 1699 & $\mathrm{CC}$ & $1.0 \mathrm{E}+00$ & $9.9 \mathrm{E}-01$ & $9.4 \mathrm{E}-01$ & $6.5 \mathrm{E}-01$ & $1.5 \mathrm{E}-01$ & $1.9 \mathrm{E}-02$ & $1.9 \mathrm{E}-03$ & $3.5 \mathrm{E}-04$ & $3.9 \mathrm{E}-05$ & $5.5 \mathrm{E}-06$ & 8.4E-07 \\
\hline $\mathrm{D}$ & 1 & 1699 & $\mathrm{CC}$ & $1.0 \mathrm{E}+00$ & $1.0 \mathrm{E}+00$ & $9.7 \mathrm{E}-01$ & 7.8E-01 & $2.4 \mathrm{E}-01$ & $3.4 \mathrm{E}-02$ & $3.4 \mathrm{E}-03$ & $6.5 \mathrm{E}-04$ & $9.9 \mathrm{E}-05$ & $1.8 \mathrm{E}-05$ & $3.5 \mathrm{E}-06$ \\
\hline $\bar{E}$ & 1 & 1699 & $\mathrm{CC}$ & $1.0 \mathrm{E}+00$ & $1.0 \mathrm{E}+00$ & $9.9 \mathrm{E}-01$ & $9.0 \mathrm{E}-01$ & $4.6 \mathrm{E}-01$ & $8.6 \mathrm{E}-02$ & $8.6 \mathrm{E}-03$ & $1.1 \mathrm{E}-03$ & $2.0 \mathrm{E}-04$ & $3.9 \mathrm{E}-05$ & $9.3 \mathrm{E}-06$ \\
\hline$F$ & 1 & 1699 & $\mathrm{CC}$ & $1.0 \mathrm{E}+00$ & $1.0 \mathrm{E}+00$ & $1.0 \mathrm{E}+00$ & $9.6 \mathrm{E}-01$ & $7.0 \mathrm{E}-01$ & $2.1 \mathrm{E}-01$ & $2.4 \mathrm{E}-02$ & $2.9 \mathrm{E}-03$ & 4.4E-04 & $1.0 \mathrm{E}-04$ & $2.5 \mathrm{E}-05$ \\
\hline$G$ & 1 & 1699 & $\mathrm{CC}$ & $1.0 \mathrm{E}+00$ & $1.0 \mathrm{E}+00$ & $1.0 \mathrm{E}+00$ & 9.9E-01 & $8.7 \mathrm{E}-01$ & $4.2 \mathrm{E}-01$ & $6.3 \mathrm{E}-02$ & $8.0 \mathrm{E}-03$ & $9.2 \mathrm{E}-04$ & $2.3 \mathrm{E}-04$ & $6.4 \mathrm{E}-05$ \\
\hline A & 3.4 & 1699 & $\mathrm{CC}$ & $9.9 \mathrm{E}-01$ & $9.2 \mathrm{E}-01$ & $5.0 \mathrm{E}-01$ & $1.0 \mathrm{E}-01$ & $9.9 \mathrm{E}-03$ & $1.1 \mathrm{E}-03$ & $1.7 \mathrm{E}-04$ & $2.2 \mathrm{E}-05$ & $2.1 \mathrm{E}-06$ & $2.5 \mathrm{E}-07$ & $2.8 \mathrm{E}-08$ \\
\hline B & 3.4 & 1699 & $\mathrm{CC}$ & $1.0 \mathrm{E}+00$ & $9.6 \mathrm{E}-01$ & $7.0 \mathrm{E}-01$ & $2.0 \mathrm{E}-01$ & $2.3 \mathrm{E}-02$ & $2.6 \mathrm{E}-03$ & $3.2 \mathrm{E}-04$ & $4.9 \mathrm{E}-05$ & $4.8 \mathrm{E}-06$ & $5.8 \mathrm{E}-07$ & $6.5 \mathrm{E}-08$ \\
\hline $\mathrm{C}$ & 3.4 & 1699 & $\mathrm{CC}$ & $1.0 \mathrm{E}+00$ & $9.8 \mathrm{E}-01$ & $8.3 \mathrm{E}-01$ & $3.6 \mathrm{E}-01$ & $4.8 \mathrm{E}-02$ & $5.6 \mathrm{E}-03$ & $5.6 \mathrm{E}-04$ & $1.0 \mathrm{E}-04$ & $1.1 \mathrm{E}-05$ & $1.6 \mathrm{E}-06$ & $2.5 \mathrm{E}-07$ \\
\hline $\mathrm{D}$ & 3.4 & 1699 & $\mathrm{CC}$ & $1.0 \mathrm{E}+00$ & $9.9 \mathrm{E}-01$ & $9.0 \mathrm{E}-01$ & $5.1 \mathrm{E}-01$ & $8.5 \mathrm{E}-02$ & $1.0 \mathrm{E}-02$ & $1.0 \mathrm{E}-03$ & $1.9 \mathrm{E}-04$ & $2.9 \mathrm{E}-05$ & $5.4 \mathrm{E}-06$ & $1.0 \mathrm{E}-06$ \\
\hline $\mathrm{E}$ & 3.4 & 1699 & $\mathrm{CC}$ & $1.0 \mathrm{E}+00$ & $9.9 \mathrm{E}-01$ & $9.6 \mathrm{E}-01$ & 7.3E-01 & $2.0 \mathrm{E}-01$ & $2.7 \mathrm{E}-02$ & $2.5 \mathrm{E}-03$ & $3.4 \mathrm{E}-04$ & $5.9 \mathrm{E}-05$ & $1.1 \mathrm{E}-05$ & 2.7E-06 \\
\hline$F$ & 3.4 & 1699 & $\mathrm{CC}$ & $1.0 \mathrm{E}+00$ & $1.0 \mathrm{E}+00$ & $9.9 \mathrm{E}-01$ & $8.8 \mathrm{E}-01$ & $4.1 \mathrm{E}-01$ & 7.2E-02 & 7.1E-03 & $8.5 \mathrm{E}-04$ & $1.3 \mathrm{E}-04$ & $3.0 \mathrm{E}-05$ & $7.5 \mathrm{E}-06$ \\
\hline G & 3.4 & 1699 & $\mathrm{CC}$ & $1.0 \mathrm{E}+00$ & $1.0 \mathrm{E}+00$ & $9.9 \mathrm{E}-01$ & 9.6E-01 & $6.6 \mathrm{E}-01$ & $1.8 \mathrm{E}-01$ & $2.0 \mathrm{E}-02$ & $2.4 \mathrm{E}-03$ & $2.7 \mathrm{E}-04$ & $6.7 \mathrm{E}-05$ & $1.9 \mathrm{E}-05$ \\
\hline $\mathrm{C}$ & 10 & 1699 & $\mathrm{CC}$ & $9.9 \mathrm{E}-01$ & $9.5 \mathrm{E}-01$ & $6.3 \mathrm{E}-01$ & $1.6 \mathrm{E}-01$ & $1.7 \mathrm{E}-02$ & $1.9 \mathrm{E}-03$ & $1.9 \mathrm{E}-04$ & $3.5 \mathrm{E}-05$ & $3.9 \mathrm{E}-06$ & $5.5 \mathrm{E}-07$ & $8.4 \mathrm{E}-08$ \\
\hline $\mathrm{D}$ & 10 & 1699 & $\mathrm{CC}$ & $1.0 \mathrm{E}+00$ & $9.7 \mathrm{E}-01$ & 7.6E-01 & $2.6 \mathrm{E}-01$ & $3.1 \mathrm{E}-02$ & $3.5 \mathrm{E}-03$ & $3.4 \mathrm{E}-04$ & $6.5 \mathrm{E}-05$ & $9.9 \mathrm{E}-06$ & $1.8 \mathrm{E}-06$ & $3.5 \mathrm{E}-07$ \\
\hline $\bar{E}$ & 10 & 1699 & $\mathrm{CC}$ & $1.0 \mathrm{E}+00$ & $9.9 \mathrm{E}-01$ & $8.9 \mathrm{E}-01$ & $4.8 \mathrm{E}-01$ & $7.7 \mathrm{E}-02$ & $9.3 \mathrm{E}-03$ & 8.6E-04 & $1.1 \mathrm{E}-04$ & $2.0 \mathrm{E}-05$ & $3.9 \mathrm{E}-06$ & $9.3 \mathrm{E}-07$ \\
\hline $\mathrm{C}$ & 20 & 1699 & $\mathrm{CC}$ & $9.9 \mathrm{E}-01$ & $9.0 \mathrm{E}-01$ & 4.6E-01 & $8.7 \mathrm{E}-02$ & $8.5 \mathrm{E}-03$ & $9.5 \mathrm{E}-04$ & $9.5 \mathrm{E}-05$ & $1.7 \mathrm{E}-05$ & $1.9 \mathrm{E}-06$ & $2.7 \mathrm{E}-07$ & $4.2 \mathrm{E}-08$ \\
\hline $\mathrm{D}$ & 20 & 1699 & $\mathrm{CC}$ & $9.9 \mathrm{E}-01$ & 9.4E-01 & $6.1 \mathrm{E}-01$ & $1.5 \mathrm{E}-01$ & $1.6 \mathrm{E}-02$ & $1.8 \mathrm{E}-03$ & $1.7 \mathrm{E}-04$ & $3.2 \mathrm{E}-05$ & $4.9 \mathrm{E}-06$ & $9.2 \mathrm{E}-07$ & $1.8 \mathrm{E}-07$ \\
\hline $\mathrm{E}$ & 20 & 1699 & $\mathrm{CC}$ & $1.0 \mathrm{E}+00$ & $9.7 \mathrm{E}-01$ & $8.1 \mathrm{E}-01$ & 3.2E-01 & $4.0 \mathrm{E}-02$ & $4.7 \mathrm{E}-03$ & $4.3 \mathrm{E}-04$ & 5.7E-05 & $1.0 \mathrm{E}-05$ & $1.9 \mathrm{E}-06$ & 4.7E-07 \\
\hline
\end{tabular}


Table A.2. (contd)

\begin{tabular}{|c|c|c|c|c|c|c|c|c|c|c|c|c|c|c|}
\hline \multirow{2}{*}{$\begin{array}{c}\text { Stability } \\
\text { Class }\end{array}$} & \multirow{2}{*}{$\begin{array}{c}\text { Wind } \\
\text { Speed } \\
\mathbf{m} / \mathbf{s}\end{array}$} & \multirow{2}{*}{$\begin{array}{c}\text { Venting } \\
\text { Rate } \\
\text { m3/hr }\end{array}$} & \multirow[b]{2}{*}{ Conc } & \multicolumn{3}{|c|}{ Distance Downwind, $\mathrm{m}$} & \multirow[b]{2}{*}{3} & \multirow[b]{2}{*}{10} & \multirow[b]{2}{*}{30} & \multirow[b]{2}{*}{100} & \multirow[b]{2}{*}{300} & \multirow[b]{2}{*}{1000} & \multirow[b]{2}{*}{3000} & \multirow[b]{2}{*}{10,000} \\
\hline & & & & 0.001 & 0.3 & 1 & & & & & & & & \\
\hline A & 1 & 3398 & $\mathrm{GC}$ & $0.0 \mathrm{E}+00$ & $0.0 \mathrm{E}+00$ & $0.0 \mathrm{E}+00$ & $2.5 \mathrm{E}-35$ & $5.4 \mathrm{E}-05$ & $5.6 \mathrm{E}-03$ & $1.3 \mathrm{E}-03$ & $1.5 \mathrm{E}-04$ & $1.4 \mathrm{E}-05$ & $1.7 \mathrm{E}-06$ & $1.9 \mathrm{E}-07$ \\
\hline B & 1 & 3398 & GC & $0.0 \mathrm{E}+00$ & $0.0 \mathrm{E}+00$ & $0.0 \mathrm{E}+00$ & $0.0 \mathrm{E}+00$ & $3.7 \mathrm{E}-10$ & $2.4 \mathrm{E}-03$ & $2.4 \mathrm{E}-03$ & $3.4 \mathrm{E}-04$ & 3.3E-05 & $4.0 \mathrm{E}-06$ & $4.4 \mathrm{E}-07$ \\
\hline $\mathrm{C}$ & 1 & 3398 & $\mathrm{GC}$ & $0.0 \mathrm{E}+00$ & $0.0 \mathrm{E}+00$ & $0.0 \mathrm{E}+00$ & $0.0 \mathrm{E}+00$ & $1.3 \mathrm{E}-20$ & $2.7 \mathrm{E}-04$ & $3.9 \mathrm{E}-03$ & 7.4E-04 & $7.8 \mathrm{E}-05$ & $1.1 \mathrm{E}-05$ & $1.7 \mathrm{E}-06$ \\
\hline $\mathrm{D}$ & 1 & 3398 & GC & $0.0 \mathrm{E}+00$ & $0.0 \mathrm{E}+00$ & $0.0 \mathrm{E}+00$ & $0.0 \mathrm{E}+00$ & $6.8 \mathrm{E}-36$ & 7.1E-06 & $4.3 \mathrm{E}-03$ & $1.4 \mathrm{E}-03$ & $2.0 \mathrm{E}-04$ & $3.7 \mathrm{E}-05$ & 7.1E-06 \\
\hline $\mathrm{E}$ & 1 & 3398 & GC & $0.0 \mathrm{E}+00$ & $0.0 \mathrm{E}+00$ & $0.0 \mathrm{E}+00$ & $0.0 \mathrm{E}+00$ & $0.0 \mathrm{E}+00$ & $5.1 \mathrm{E}-17$ & $6.8 \mathrm{E}-04$ & $2.4 \mathrm{E}-03$ & $4.2 \mathrm{E}-04$ & 7.9E-05 & $1.9 \mathrm{E}-05$ \\
\hline $\mathrm{F}$ & 1 & 3398 & GC & $0.0 \mathrm{E}+00$ & $0.0 \mathrm{E}+00$ & $0.0 \mathrm{E}+00$ & $0.0 \mathrm{E}+00$ & $0.0 \mathrm{E}+00$ & $0.0 \mathrm{E}+00$ & $3.6 \mathrm{E}-07$ & $1.9 \mathrm{E}-03$ & $1.0 \mathrm{E}-03$ & $2.1 \mathrm{E}-04$ & $5.2 \mathrm{E}-05$ \\
\hline G & 1 & 3398 & $\overline{G C}$ & $0.0 \mathrm{E}+00$ & $0.0 \mathrm{E}+00$ & $0.0 \mathrm{E}+00$ & $0.0 \mathrm{E}+00$ & $0.0 \mathrm{E}+00$ & $0.0 \mathrm{E}+00$ & $9.5 \mathrm{E}-20$ & $9.3 \mathrm{E}-05$ & $1.5 \mathrm{E}-03$ & $5.1 \mathrm{E}-04$ & $1.4 \mathrm{E}-04$ \\
\hline $\mathrm{A}$ & 3.4 & 3398 & $\mathrm{GC}$ & $0.0 \mathrm{E}+00$ & $0.0 \mathrm{E}+00$ & $0.0 \mathrm{E}+00$ & $1.0 \mathrm{E}-35$ & $1.7 \mathrm{E}-05$ & $1.6 \mathrm{E}-03$ & 3.7E-04 & $4.5 \mathrm{E}-05$ & $4.2 \mathrm{E}-06$ & $5.1 \mathrm{E}-07$ & $5.7 \mathrm{E}-08$ \\
\hline $\mathrm{B}$ & 3.4 & 3398 & $\mathrm{GC}$ & $0.0 \mathrm{E}+00$ & $0.0 \mathrm{E}+00$ & $0.0 \mathrm{E}+00$ & $0.0 \mathrm{E}+00$ & $1.2 \mathrm{E}-10$ & $7.2 \mathrm{E}-04$ & $7.2 \mathrm{E}-04$ & $1.0 \mathrm{E}-04$ & $9.6 \mathrm{E}-06$ & $1.2 \mathrm{E}-06$ & $1.3 \mathrm{E}-07$ \\
\hline $\mathrm{C}$ & 3.4 & 3398 & GC & $0.0 \mathrm{E}+00$ & $0.0 \mathrm{E}+00$ & $0.0 \mathrm{E}+00$ & $0.0 \mathrm{E}+00$ & $4.6 \mathrm{E}-21$ & $8.2 \mathrm{E}-05$ & $1.1 \mathrm{E}-03$ & 2.2E-04 & $2.3 \mathrm{E}-05$ & $3.2 \mathrm{E}-06$ & $4.9 \mathrm{E}-07$ \\
\hline $\mathrm{D}$ & 3.4 & 3398 & GC & $0.0 \mathrm{E}+00$ & $0.0 \mathrm{E}+00$ & $0.0 \mathrm{E}+00$ & $0.0 \mathrm{E}+00$ & $2.8 \mathrm{E}-36$ & $2.2 \mathrm{E}-06$ & $1.3 \mathrm{E}-03$ & $4.2 \mathrm{E}-04$ & $6.0 \mathrm{E}-05$ & $1.1 \mathrm{E}-05$ & $2.1 \mathrm{E}-06$ \\
\hline $\mathrm{E}$ & 3.4 & 3398 & GC & $0.0 \mathrm{E}+00$ & $0.0 \mathrm{E}+00$ & $0.0 \mathrm{E}+00$ & $0.0 \mathrm{E}+00$ & $0.0 \mathrm{E}+00$ & $1.7 \mathrm{E}-17$ & $2.0 \mathrm{E}-04$ & 7.1E-04 & $1.2 \mathrm{E}-04$ & $2.3 \mathrm{E}-05$ & $5.5 \mathrm{E}-06$ \\
\hline $\mathrm{F}$ & 3.4 & 3398 & GC & $0.0 \mathrm{E}+00$ & $0.0 \mathrm{E}+00$ & $0.0 \mathrm{E}+00$ & $0.0 \mathrm{E}+00$ & $0.0 \mathrm{E}+00$ & $0.0 \mathrm{E}+00$ & $1.1 \mathrm{E}-07$ & $5.5 \mathrm{E}-04$ & $3.0 \mathrm{E}-04$ & $6.3 \mathrm{E}-05$ & $1.5 \mathrm{E}-05$ \\
\hline G & 3.4 & 3398 & GC & $0.0 \mathrm{E}+00$ & $0.0 \mathrm{E}+00$ & $0.0 \mathrm{E}+00$ & $0.0 \mathrm{E}+00$ & $0.0 \mathrm{E}+00$ & $0.0 \mathrm{E}+00$ & $3.0 \mathrm{E}-20$ & $2.8 \mathrm{E}-05$ & $4.5 \mathrm{E}-04$ & $1.5 \mathrm{E}-04$ & $4.0 \mathrm{E}-05$ \\
\hline $\mathrm{C}$ & 10 & 3398 & GC & $0.0 \mathrm{E}+00$ & $0.0 \mathrm{E}+00$ & $0.0 \mathrm{E}+00$ & $0.0 \mathrm{E}+00$ & $1.7 \mathrm{E}-21$ & $2.8 \mathrm{E}-05$ & $3.9 \mathrm{E}-04$ & 7.4E-05 & $7.8 \mathrm{E}-06$ & $1.1 \mathrm{E}-06$ & $1.7 \mathrm{E}-07$ \\
\hline $\mathrm{D}$ & 10 & 3398 & GC & $0.0 \mathrm{E}+00$ & $0.0 \mathrm{E}+00$ & $0.0 \mathrm{E}+00$ & $0.0 \mathrm{E}+00$ & $1.0 \mathrm{E}-36$ & $7.5 \mathrm{E}-07$ & $4.3 \mathrm{E}-04$ & $1.4 \mathrm{E}-04$ & $2.0 \mathrm{E}-05$ & 3.7E-06 & $7.1 \mathrm{E}-07$ \\
\hline $\mathrm{E}$ & 10 & 3398 & GC & $0.0 \mathrm{E}+00$ & $0.0 \mathrm{E}+00$ & $0.0 \mathrm{E}+00$ & $0.0 \mathrm{E}+00$ & $0.0 \mathrm{E}+00$ & $5.9 \mathrm{E}-18$ & $6.9 \mathrm{E}-05$ & $2.4 \mathrm{E}-04$ & $4.2 \mathrm{E}-05$ & $7.9 \mathrm{E}-06$ & $1.9 \mathrm{E}-06$ \\
\hline $\mathrm{C}$ & 20 & 3398 & GC & $0.0 \mathrm{E}+00$ & $0.0 \mathrm{E}+00$ & $0.0 \mathrm{E}+00$ & $0.0 \mathrm{E}+00$ & $8.4 \mathrm{E}-22$ & $1.4 \mathrm{E}-05$ & $1.9 \mathrm{E}-04$ & $3.7 \mathrm{E}-05$ & $3.9 \mathrm{E}-06$ & $5.5 \mathrm{E}-07$ & $8.4 \mathrm{E}-08$ \\
\hline $\mathrm{D}$ & 20 & 3398 & GC & $0.0 \mathrm{E}+00$ & $0.0 \mathrm{E}+00$ & $0.0 \mathrm{E}+00$ & $0.0 \mathrm{E}+00$ & $5.4 \mathrm{E}-37$ & $3.8 \mathrm{E}-07$ & $2.2 \mathrm{E}-04$ & 7.2E-05 & $1.0 \mathrm{E}-05$ & $1.8 \mathrm{E}-06$ & $3.5 \mathrm{E}-07$ \\
\hline $\mathrm{E}$ & 20 & 3398 & GC & $0.0 \mathrm{E}+00$ & $0.0 \mathrm{E}+00$ & $0.0 \mathrm{E}+00$ & $0.0 \mathrm{E}+00$ & $0.0 \mathrm{E}+00$ & $3.0 \mathrm{E}-18$ & $3.4 \mathrm{E}-05$ & $1.2 \mathrm{E}-04$ & $2.1 \mathrm{E}-05$ & $4.0 \mathrm{E}-06$ & 9.4E-07 \\
\hline
\end{tabular}


Table A.2. (contd)

\begin{tabular}{|c|c|c|c|c|c|c|c|c|c|c|c|c|c|c|}
\hline \multirow{2}{*}{$\begin{array}{c}\text { Stability } \\
\text { Class }\end{array}$} & \multirow{2}{*}{$\begin{array}{c}\text { Wind } \\
\text { Speed } \\
\mathbf{m} / \mathbf{s}\end{array}$} & \multirow{2}{*}{$\begin{array}{c}\text { Venting } \\
\text { Rate } \\
\text { m3/hr }\end{array}$} & \multirow[b]{2}{*}{ Conc } & \multicolumn{3}{|c|}{ Distance Downwind, m } & \multirow[b]{2}{*}{3} & \multirow[b]{2}{*}{10} & \multirow[b]{2}{*}{30} & \multirow[b]{2}{*}{100} & \multirow[b]{2}{*}{300} & \multirow[b]{2}{*}{1000} & \multirow[b]{2}{*}{3000} & \multirow[b]{2}{*}{10,000} \\
\hline & & & & 0.001 & 0.3 & 1 & & & & & & & & \\
\hline A & 1 & 3398 & $\mathrm{CC}$ & $1.0 \mathrm{E}+00$ & $9.9 \mathrm{E}-01$ & 8.7E-01 & 4.3E-01 & $6.4 \mathrm{E}-02$ & 7.7E-03 & $1.2 \mathrm{E}-03$ & $1.5 \mathrm{E}-04$ & $1.4 \mathrm{E}-05$ & $1.7 \mathrm{E}-06$ & $1.9 \mathrm{E}-07$ \\
\hline B & 1 & 3398 & $\mathrm{CC}$ & $1.0 \mathrm{E}+00$ & $9.9 \mathrm{E}-01$ & $9.4 \mathrm{E}-01$ & $6.3 \mathrm{E}-01$ & $1.4 \mathrm{E}-01$ & $1.7 \mathrm{E}-02$ & $2.1 \mathrm{E}-03$ & 3.3E-04 & $3.3 \mathrm{E}-05$ & $4.0 \mathrm{E}-06$ & 4.4E-07 \\
\hline $\mathrm{C}$ & 1 & 3398 & $\mathrm{CC}$ & $1.0 \mathrm{E}+00$ & $1.0 \mathrm{E}+00$ & $9.7 \mathrm{E}-01$ & $7.9 \mathrm{E}-01$ & $2.5 \mathrm{E}-01$ & $3.7 \mathrm{E}-02$ & $3.8 \mathrm{E}-03$ & $7.0 \mathrm{E}-04$ & $7.7 \mathrm{E}-05$ & $1.1 \mathrm{E}-05$ & $1.7 \mathrm{E}-06$ \\
\hline $\mathrm{D}$ & 1 & 3398 & $\mathrm{CC}$ & $1.0 \mathrm{E}+00$ & $1.0 \mathrm{E}+00$ & $9.8 \mathrm{E}-01$ & $8.7 \mathrm{E}-01$ & $3.9 \mathrm{E}-01$ & $6.6 \mathrm{E}-02$ & $6.8 \mathrm{E}-03$ & $1.3 \mathrm{E}-03$ & $2.0 \mathrm{E}-04$ & $3.7 \mathrm{E}-05$ & 7.1E-06 \\
\hline $\bar{E}$ & 1 & 3398 & $\mathrm{CC}$ & $1.0 \mathrm{E}+00$ & $1.0 \mathrm{E}+00$ & $9.9 \mathrm{E}-01$ & $9.5 \mathrm{E}-01$ & $6.3 \mathrm{E}-01$ & $1.6 \mathrm{E}-01$ & $1.7 \mathrm{E}-02$ & $2.3 \mathrm{E}-03$ & $4.0 \mathrm{E}-04$ & $7.8 \mathrm{E}-05$ & $1.9 \mathrm{E}-05$ \\
\hline $\mathrm{F}$ & 1 & 3398 & $\mathrm{CC}$ & $1.0 \mathrm{E}+00$ & $1.0 \mathrm{E}+00$ & $1.0 \mathrm{E}+00$ & $9.8 \mathrm{E}-01$ & $8.2 \mathrm{E}-01$ & $3.5 \mathrm{E}-01$ & $4.6 \mathrm{E}-02$ & $5.7 \mathrm{E}-03$ & $8.8 \mathrm{E}-04$ & $2.0 \mathrm{E}-04$ & $5.1 \mathrm{E}-05$ \\
\hline G & 1 & 3398 & $\overline{\mathrm{CC}}$ & $1.0 \mathrm{E}+00$ & $1.0 \mathrm{E}+00$ & $1.0 \mathrm{E}+00$ & $9.9 \mathrm{E}-01$ & $9.3 \mathrm{E}-01$ & $6.0 \mathrm{E}-01$ & $1.2 \mathrm{E}-01$ & $1.6 \mathrm{E}-02$ & $1.8 \mathrm{E}-03$ & $4.6 \mathrm{E}-04$ & $1.3 \mathrm{E}-04$ \\
\hline $\mathrm{A}$ & 3.4 & 3398 & $\mathrm{CC}$ & $1.0 \mathrm{E}+00$ & $9.6 \mathrm{E}-01$ & $6.7 \mathrm{E}-01$ & $1.8 \mathrm{E}-01$ & $2.0 \mathrm{E}-02$ & $2.3 \mathrm{E}-03$ & $3.4 \mathrm{E}-04$ & $4.4 \mathrm{E}-05$ & $4.2 \mathrm{E}-06$ & $5.1 \mathrm{E}-07$ & 5.7E-08 \\
\hline $\mathrm{B}$ & 3.4 & 3398 & $\mathrm{CC}$ & $1.0 \mathrm{E}+00$ & $9.8 \mathrm{E}-01$ & $8.2 \mathrm{E}-01$ & $3.4 \mathrm{E}-01$ & $4.4 \mathrm{E}-02$ & $5.1 \mathrm{E}-03$ & $6.3 \mathrm{E}-04$ & $9.8 \mathrm{E}-05$ & $9.6 \mathrm{E}-06$ & $1.2 \mathrm{E}-06$ & $1.3 \mathrm{E}-07$ \\
\hline $\mathrm{C}$ & 3.4 & 3398 & $\mathrm{CC}$ & $1.0 \mathrm{E}+00$ & $9.9 \mathrm{E}-01$ & $9.1 \mathrm{E}-01$ & 5.3E-01 & $9.1 \mathrm{E}-02$ & $1.1 \mathrm{E}-02$ & $1.1 \mathrm{E}-03$ & $2.1 \mathrm{E}-04$ & $2.3 \mathrm{E}-05$ & $3.2 \mathrm{E}-06$ & $4.9 \mathrm{E}-07$ \\
\hline $\mathrm{D}$ & 3.4 & 3398 & $\mathrm{CC}$ & $1.0 \mathrm{E}+00$ & $9.9 \mathrm{E}-01$ & $9.5 \mathrm{E}-01$ & $6.7 \mathrm{E}-01$ & $1.6 \mathrm{E}-01$ & $2.1 \mathrm{E}-02$ & $2.0 \mathrm{E}-03$ & $3.8 \mathrm{E}-04$ & $5.8 \mathrm{E}-05$ & $1.1 \mathrm{E}-05$ & $2.1 \mathrm{E}-06$ \\
\hline $\mathrm{E}$ & 3.4 & 3398 & $\mathrm{CC}$ & $1.0 \mathrm{E}+00$ & $1.0 \mathrm{E}+00$ & $9.8 \mathrm{E}-01$ & $8.5 \mathrm{E}-01$ & 3.3E-01 & $5.2 \mathrm{E}-02$ & $5.1 \mathrm{E}-03$ & $6.7 \mathrm{E}-04$ & $1.2 \mathrm{E}-04$ & $2.3 \mathrm{E}-05$ & $5.5 \mathrm{E}-06$ \\
\hline$F$ & 3.4 & 3398 & $\mathrm{CC}$ & $1.0 \mathrm{E}+00$ & $1.0 \mathrm{E}+00$ & $9.9 \mathrm{E}-01$ & 9.4E-01 & $5.8 \mathrm{E}-01$ & $1.3 \mathrm{E}-01$ & $1.4 \mathrm{E}-02$ & $1.7 \mathrm{E}-03$ & $2.6 \mathrm{E}-04$ & $6.0 \mathrm{E}-05$ & $1.5 \mathrm{E}-05$ \\
\hline$G$ & 3.4 & 3398 & $\mathrm{CC}$ & $1.0 \mathrm{E}+00$ & $1.0 \mathrm{E}+00$ & $1.0 \mathrm{E}+00$ & $9.8 \mathrm{E}-01$ & 7.9E-01 & $3.0 \mathrm{E}-01$ & $3.8 \mathrm{E}-02$ & $4.7 \mathrm{E}-03$ & $5.4 \mathrm{E}-04$ & $1.3 \mathrm{E}-04$ & $3.8 \mathrm{E}-05$ \\
\hline $\mathrm{C}$ & 10 & 3398 & $\mathrm{CC}$ & $1.0 \mathrm{E}+00$ & $9.7 \mathrm{E}-01$ & 7.7E-01 & $2.8 \mathrm{E}-01$ & $3.3 \mathrm{E}-02$ & $3.8 \mathrm{E}-03$ & $3.8 \mathrm{E}-04$ & $7.0 \mathrm{E}-05$ & 7.7E-06 & $1.1 \mathrm{E}-06$ & $1.7 \mathrm{E}-07$ \\
\hline $\mathrm{D}$ & 10 & 3398 & $\mathrm{CC}$ & $1.0 \mathrm{E}+00$ & $9.8 \mathrm{E}-01$ & $8.6 \mathrm{E}-01$ & 4.1E-01 & $5.9 \mathrm{E}-02$ & $7.1 \mathrm{E}-03$ & $6.8 \mathrm{E}-04$ & $1.3 \mathrm{E}-04$ & $2.0 \mathrm{E}-05$ & 3.7E-06 & $7.1 \mathrm{E}-07$ \\
\hline $\mathrm{E}$ & 10 & 3398 & $\mathrm{CC}$ & $1.0 \mathrm{E}+00$ & $9.9 \mathrm{E}-01$ & $9.4 \mathrm{E}-01$ & $6.5 \mathrm{E}-01$ & $1.4 \mathrm{E}-01$ & $1.8 \mathrm{E}-02$ & $1.7 \mathrm{E}-03$ & 2.3E-04 & $4.0 \mathrm{E}-05$ & $7.8 \mathrm{E}-06$ & $1.9 \mathrm{E}-06$ \\
\hline $\mathrm{C}$ & 20 & 3398 & $\mathrm{CC}$ & $9.9 \mathrm{E}-01$ & $9.5 \mathrm{E}-01$ & $6.3 \mathrm{E}-01$ & $1.6 \mathrm{E}-01$ & $1.7 \mathrm{E}-02$ & $1.9 \mathrm{E}-03$ & $1.9 \mathrm{E}-04$ & $3.5 \mathrm{E}-05$ & $3.9 \mathrm{E}-06$ & $5.5 \mathrm{E}-07$ & $8.4 \mathrm{E}-08$ \\
\hline $\mathrm{D}$ & 20 & 3398 & $\mathrm{CC}$ & $1.0 \mathrm{E}+00$ & $9.7 \mathrm{E}-01$ & 7.6E-01 & 2.6E-01 & $3.1 \mathrm{E}-02$ & $3.5 \mathrm{E}-03$ & 3.4E-04 & $6.5 \mathrm{E}-05$ & $9.9 \mathrm{E}-06$ & $1.8 \mathrm{E}-06$ & $3.5 \mathrm{E}-07$ \\
\hline $\mathrm{E}$ & 20 & 3398 & $\mathrm{CC}$ & $1.0 \mathrm{E}+00$ & $9.9 \mathrm{E}-01$ & $8.9 \mathrm{E}-01$ & $4.8 \mathrm{E}-01$ & $7.7 \mathrm{E}-02$ & $9.3 \mathrm{E}-03$ & $8.6 \mathrm{E}-04$ & $1.1 \mathrm{E}-04$ & $2.0 \mathrm{E}-05$ & $3.9 \mathrm{E}-06$ & $9.3 \mathrm{E}-07$ \\
\hline
\end{tabular}


Table A.3. AP Farm W/ Extension; Fractional Concentrations at Ground Level (GC) and Plume Centerline (CC)

\begin{tabular}{|c|c|c|c|c|c|c|c|c|c|c|c|c|c|c|}
\hline \multirow{2}{*}{$\begin{array}{c}\text { Stability } \\
\text { Class }\end{array}$} & \multirow{2}{*}{$\begin{array}{c}\text { Wind } \\
\text { Speed } \\
\mathbf{m} / \mathbf{s}\end{array}$} & \multirow{2}{*}{$\begin{array}{c}\text { Venting } \\
\text { Rate } \\
\text { m3/hr }\end{array}$} & \multirow[b]{2}{*}{ Conc } & \multicolumn{3}{|c|}{ Distance Downwind, m } & \multirow[b]{2}{*}{3} & \multirow[b]{2}{*}{10} & \multirow[b]{2}{*}{30} & \multirow[b]{2}{*}{100} & \multirow[b]{2}{*}{300} & \multirow[b]{2}{*}{1000} & \multirow[b]{2}{*}{3000} & \multirow[b]{2}{*}{10,000} \\
\hline & & & & 0.001 & 0.3 & 1 & & & & & & & & \\
\hline A & 1 & 1359 & $\mathrm{GC}$ & $0.0 \mathrm{E}+00$ & $0.0 \mathrm{E}+00$ & $0.0 \mathrm{E}+00$ & $3.0 \mathrm{E}-16$ & $1.3 \mathrm{E}-03$ & $3.7 \mathrm{E}-03$ & $5.2 \mathrm{E}-04$ & $6.1 \mathrm{E}-05$ & 5.7E-06 & $6.9 \mathrm{E}-07$ & 7.7E-08 \\
\hline $\mathrm{B}$ & 1 & 1359 & $\mathrm{GC}$ & $0.0 \mathrm{E}+00$ & $0.0 \mathrm{E}+00$ & $0.0 \mathrm{E}+00$ & $1.7 \mathrm{E}-42$ & $1.1 \mathrm{E}-05$ & $3.7 \mathrm{E}-03$ & $1.1 \mathrm{E}-03$ & $1.4 \mathrm{E}-04$ & $1.3 \mathrm{E}-05$ & $1.6 \mathrm{E}-06$ & $1.8 \mathrm{E}-07$ \\
\hline $\mathrm{C}$ & 1 & 1359 & GC & $0.0 \mathrm{E}+00$ & $0.0 \mathrm{E}+00$ & $0.0 \mathrm{E}+00$ & $0.0 \mathrm{E}+00$ & $4.9 \mathrm{E}-10$ & $2.0 \mathrm{E}-03$ & $2.1 \mathrm{E}-03$ & $3.1 \mathrm{E}-04$ & $3.1 \mathrm{E}-05$ & 4.4E-06 & $6.7 \mathrm{E}-07$ \\
\hline $\mathrm{D}$ & 1 & 1359 & GC & $0.0 \mathrm{E}+00$ & $0.0 \mathrm{E}+00$ & $0.0 \mathrm{E}+00$ & $0.0 \mathrm{E}+00$ & $1.5 \mathrm{E}-16$ & $5.3 \mathrm{E}-04$ & $3.1 \mathrm{E}-03$ & $6.3 \mathrm{E}-04$ & 8.2E-05 & $1.5 \mathrm{E}-05$ & $2.8 \mathrm{E}-06$ \\
\hline $\mathrm{E}$ & 1 & 1359 & GC & $0.0 \mathrm{E}+00$ & $0.0 \mathrm{E}+00$ & $0.0 \mathrm{E}+00$ & $0.0 \mathrm{E}+00$ & $0.0 \mathrm{E}+00$ & $1.3 \mathrm{E}-08$ & $2.0 \mathrm{E}-03$ & $1.3 \mathrm{E}-03$ & $1.8 \mathrm{E}-04$ & $3.2 \mathrm{E}-05$ & 7.5E-06 \\
\hline $\mathrm{F}$ & 1 & 1359 & GC & $0.0 \mathrm{E}+00$ & $0.0 \mathrm{E}+00$ & $0.0 \mathrm{E}+00$ & $0.0 \mathrm{E}+00$ & $0.0 \mathrm{E}+00$ & $3.5 \mathrm{E}-25$ & $1.2 \mathrm{E}-04$ & $1.9 \mathrm{E}-03$ & $4.5 \mathrm{E}-04$ & $8.8 \mathrm{E}-05$ & $2.1 \mathrm{E}-05$ \\
\hline A & 3.4 & 1359 & GC & $0.0 \mathrm{E}+00$ & $0.0 \mathrm{E}+00$ & $0.0 \mathrm{E}+00$ & $1.0 \mathrm{E}-16$ & $3.8 \mathrm{E}-04$ & $1.1 \mathrm{E}-03$ & $1.5 \mathrm{E}-04$ & $1.8 \mathrm{E}-05$ & 1.7E-06 & $2.0 \mathrm{E}-07$ & 2.3E-08 \\
\hline $\mathrm{B}$ & 3.4 & 1359 & GC & $0.0 \mathrm{E}+00$ & $0.0 \mathrm{E}+00$ & $0.0 \mathrm{E}+00$ & $7.2 \mathrm{E}-43$ & 3.4E-06 & $1.1 \mathrm{E}-03$ & 3.3E-04 & 4.1E-05 & 3.9E-06 & 4.7E-07 & $5.2 \mathrm{E}-08$ \\
\hline $\mathrm{C}$ & 3.4 & 1359 & GC & $0.0 \mathrm{E}+00$ & $0.0 \mathrm{E}+00$ & $0.0 \mathrm{E}+00$ & $0.0 \mathrm{E}+00$ & $1.6 \mathrm{E}-10$ & $5.8 \mathrm{E}-04$ & $6.1 \mathrm{E}-04$ & $9.0 \mathrm{E}-05$ & $9.2 \mathrm{E}-06$ & $1.3 \mathrm{E}-06$ & $2.0 \mathrm{E}-07$ \\
\hline $\mathrm{D}$ & 3.4 & 1359 & GC & $0.0 \mathrm{E}+00$ & $0.0 \mathrm{E}+00$ & $0.0 \mathrm{E}+00$ & $0.0 \mathrm{E}+00$ & $5.3 \mathrm{E}-17$ & $1.6 \mathrm{E}-04$ & $9.0 \mathrm{E}-04$ & $1.8 \mathrm{E}-04$ & $2.4 \mathrm{E}-05$ & 4.4E-06 & $8.3 \mathrm{E}-07$ \\
\hline $\mathrm{E}$ & 3.4 & 1359 & GC & $0.0 \mathrm{E}+00$ & $0.0 \mathrm{E}+00$ & $0.0 \mathrm{E}+00$ & $0.0 \mathrm{E}+00$ & $0.0 \mathrm{E}+00$ & 3.9E-09 & 5.9E-04 & 3.7E-04 & $5.2 \mathrm{E}-05$ & 9.4E-06 & $2.2 \mathrm{E}-06$ \\
\hline $\mathrm{F}$ & 3.4 & 1359 & GC & $0.0 \mathrm{E}+00$ & $0.0 \mathrm{E}+00$ & $0.0 \mathrm{E}+00$ & $0.0 \mathrm{E}+00$ & $0.0 \mathrm{E}+00$ & $1.2 \mathrm{E}-25$ & 3.4E-05 & $5.5 \mathrm{E}-04$ & 1.3E-04 & 2.6E-05 & $6.2 \mathrm{E}-06$ \\
\hline G & 3.4 & 1359 & GC & $0.0 \mathrm{E}+00$ & $0.0 \mathrm{E}+00$ & $0.0 \mathrm{E}+00$ & $0.0 \mathrm{E}+00$ & $0.0 \mathrm{E}+00$ & $0.0 \mathrm{E}+00$ & $2.1 \mathrm{E}-10$ & 2.2E-04 & 2.8E-04 & $6.7 \mathrm{E}-05$ & $1.7 \mathrm{E}-05$ \\
\hline $\mathrm{C}$ & 10 & 1359 & GC & $0.0 \mathrm{E}+00$ & $0.0 \mathrm{E}+00$ & $0.0 \mathrm{E}+00$ & $0.0 \mathrm{E}+00$ & $5.4 \mathrm{E}-11$ & $2.0 \mathrm{E}-04$ & $2.1 \mathrm{E}-04$ & $3.1 \mathrm{E}-05$ & $3.1 \mathrm{E}-06$ & 4.4E-07 & $6.7 \mathrm{E}-08$ \\
\hline $\mathrm{D}$ & 10 & 1359 & GC & $0.0 \mathrm{E}+00$ & $0.0 \mathrm{E}+00$ & $0.0 \mathrm{E}+00$ & $0.0 \mathrm{E}+00$ & $1.9 \mathrm{E}-17$ & 5.4E-05 & 3.1E-04 & $6.3 \mathrm{E}-05$ & 8.2E-06 & $1.5 \mathrm{E}-06$ & $2.8 \mathrm{E}-07$ \\
\hline$E$ & 10 & 1359 & GC & $0.0 \mathrm{E}+00$ & $0.0 \mathrm{E}+00$ & $0.0 \mathrm{E}+00$ & $0.0 \mathrm{E}+00$ & $0.0 \mathrm{E}+00$ & $1.4 \mathrm{E}-09$ & $2.0 \mathrm{E}-04$ & $1.3 \mathrm{E}-04$ & $1.8 \mathrm{E}-05$ & $3.2 \mathrm{E}-06$ & $7.5 \mathrm{E}-07$ \\
\hline B & 20 & 1359 & GC & $0.0 \mathrm{E}+00$ & $0.0 \mathrm{E}+00$ & $0.0 \mathrm{E}+00$ & $1.4 \mathrm{E}-43$ & $5.9 \mathrm{E}-07$ & $1.9 \mathrm{E}-04$ & $5.5 \mathrm{E}-05$ & $7.0 \mathrm{E}-06$ & $6.6 \mathrm{E}-07$ & 7.9E-08 & $8.9 \mathrm{E}-09$ \\
\hline $\mathrm{C}$ & 20 & 1359 & GC & $0.0 \mathrm{E}+00$ & $0.0 \mathrm{E}+00$ & $0.0 \mathrm{E}+00$ & $0.0 \mathrm{E}+00$ & $2.7 \mathrm{E}-11$ & $9.9 \mathrm{E}-05$ & $1.0 \mathrm{E}-04$ & $1.5 \mathrm{E}-05$ & $1.6 \mathrm{E}-06$ & $2.2 \mathrm{E}-07$ & $3.3 \mathrm{E}-08$ \\
\hline $\mathrm{D}$ & 20 & 1359 & $\mathrm{GC}$ & $0.0 \mathrm{E}+00$ & $0.0 \mathrm{E}+00$ & $0.0 \mathrm{E}+00$ & $0.0 \mathrm{E}+00$ & $9.5 \mathrm{E}-18$ & 2.7E-05 & $1.5 \mathrm{E}-04$ & $3.1 \mathrm{E}-05$ & 4.1E-06 & 7.4E-07 & $1.4 \mathrm{E}-07$ \\
\hline$E$ & 20 & 1359 & GC & $0.0 \mathrm{E}+00$ & $0.0 \mathrm{E}+00$ & $0.0 \mathrm{E}+00$ & $0.0 \mathrm{E}+00$ & $0.0 \mathrm{E}+00$ & $6.8 \mathrm{E}-10$ & $1.0 \mathrm{E}-04$ & $6.3 \mathrm{E}-05$ & 8.8E-06 & $1.6 \mathrm{E}-06$ & $3.8 \mathrm{E}-07$ \\
\hline
\end{tabular}


Table A.3. (contd)

\begin{tabular}{|c|c|c|c|c|c|c|c|c|c|c|c|c|c|c|}
\hline \multirow{2}{*}{$\begin{array}{c}\text { Stability } \\
\text { Class }\end{array}$} & \multirow{2}{*}{$\begin{array}{c}\text { Wind } \\
\text { Speed } \\
\mathbf{m} / \mathbf{s}\end{array}$} & \multirow{2}{*}{$\begin{array}{c}\text { Venting } \\
\text { Rate } \\
\text { m3/hr }\end{array}$} & \multirow[b]{2}{*}{ Conc } & \multicolumn{3}{|c|}{ Distance Downwind, m } & \multirow[b]{2}{*}{3} & \multirow[b]{2}{*}{10} & \multirow[b]{2}{*}{30} & \multirow[b]{2}{*}{100} & \multirow[b]{2}{*}{300} & \multirow[b]{2}{*}{1000} & \multirow[b]{2}{*}{3000} & \multirow[b]{2}{*}{10,000} \\
\hline & & & & 0.001 & 0.3 & 1 & & & & & & & & \\
\hline A & 1 & 1359 & $\mathrm{CC}$ & $1.0 \mathrm{E}+00$ & $9.7 \mathrm{E}-01$ & 7.3E-01 & 2.3E-01 & $2.7 \mathrm{E}-02$ & $3.4 \mathrm{E}-03$ & $5.0 \mathrm{E}-04$ & $6.1 \mathrm{E}-05$ & $5.7 \mathrm{E}-06$ & $6.9 \mathrm{E}-07$ & 7.7E-08 \\
\hline B & 1 & 1359 & $\mathrm{CC}$ & $1.0 \mathrm{E}+00$ & $9.9 \mathrm{E}-01$ & $8.6 \mathrm{E}-01$ & $4.1 \mathrm{E}-01$ & $5.9 \mathrm{E}-02$ & $6.9 \mathrm{E}-03$ & $1.0 \mathrm{E}-03$ & $1.4 \mathrm{E}-04$ & $1.3 \mathrm{E}-05$ & $1.6 \mathrm{E}-06$ & $1.8 \mathrm{E}-07$ \\
\hline $\mathrm{C}$ & 1 & 1359 & $\mathrm{CC}$ & $1.0 \mathrm{E}+00$ & $9.9 \mathrm{E}-01$ & $9.3 \mathrm{E}-01$ & $6.0 \mathrm{E}-01$ & $1.2 \mathrm{E}-01$ & $1.5 \mathrm{E}-02$ & $1.8 \mathrm{E}-03$ & $3.0 \mathrm{E}-04$ & $3.1 \mathrm{E}-05$ & $4.4 \mathrm{E}-06$ & $6.7 \mathrm{E}-07$ \\
\hline $\mathrm{D}$ & 1 & 1359 & $\mathrm{CC}$ & $1.0 \mathrm{E}+00$ & $1.0 \mathrm{E}+00$ & $9.6 \mathrm{E}-01$ & 7.4E-01 & $2.0 \mathrm{E}-01$ & $2.8 \mathrm{E}-02$ & $3.0 \mathrm{E}-03$ & $5.9 \mathrm{E}-04$ & $8.1 \mathrm{E}-05$ & $1.5 \mathrm{E}-05$ & $2.8 \mathrm{E}-06$ \\
\hline $\bar{E}$ & 1 & 1359 & $\mathrm{CC}$ & $1.0 \mathrm{E}+00$ & $1.0 \mathrm{E}+00$ & $9.9 \mathrm{E}-01$ & $8.8 \mathrm{E}-01$ & $4.0 \mathrm{E}-01$ & $7.0 \mathrm{E}-02$ & $6.9 \mathrm{E}-03$ & $1.1 \mathrm{E}-03$ & $1.7 \mathrm{E}-04$ & $3.2 \mathrm{E}-05$ & $7.5 \mathrm{E}-06$ \\
\hline $\mathrm{F}$ & 1 & 1359 & $\mathrm{CC}$ & $1.0 \mathrm{E}+00$ & $1.0 \mathrm{E}+00$ & $9.9 \mathrm{E}-01$ & $9.5 \mathrm{E}-01$ & $6.5 \mathrm{E}-01$ & $1.7 \mathrm{E}-01$ & $1.9 \mathrm{E}-02$ & $2.4 \mathrm{E}-03$ & $4.2 \mathrm{E}-04$ & $8.6 \mathrm{E}-05$ & $2.1 \mathrm{E}-05$ \\
\hline G & 3.4 & 1359 & $\overline{\mathrm{CC}}$ & $1.0 \mathrm{E}+00$ & $1.0 \mathrm{E}+00$ & $9.9 \mathrm{E}-01$ & $9.4 \mathrm{E}-01$ & $6.1 \mathrm{E}-01$ & $1.5 \mathrm{E}-01$ & $1.6 \mathrm{E}-02$ & $1.9 \mathrm{E}-03$ & $2.5 \mathrm{E}-04$ & $6.2 \mathrm{E}-05$ & $1.6 \mathrm{E}-05$ \\
\hline $\mathrm{A}$ & 3.4 & 1359 & $\mathrm{CC}$ & $9.9 \mathrm{E}-01$ & $9.0 \mathrm{E}-01$ & $4.5 \mathrm{E}-01$ & $8.2 \mathrm{E}-02$ & $8.0 \mathrm{E}-03$ & $1.0 \mathrm{E}-03$ & $1.5 \mathrm{E}-04$ & $1.8 \mathrm{E}-05$ & $1.7 \mathrm{E}-06$ & $2.0 \mathrm{E}-07$ & $2.3 \mathrm{E}-08$ \\
\hline $\mathrm{B}$ & 3.4 & 1359 & $\mathrm{CC}$ & $9.9 \mathrm{E}-01$ & $9.5 \mathrm{E}-01$ & $6.5 \mathrm{E}-01$ & $1.7 \mathrm{E}-01$ & $1.8 \mathrm{E}-02$ & $2.1 \mathrm{E}-03$ & $3.0 \mathrm{E}-04$ & $4.0 \mathrm{E}-05$ & $3.9 \mathrm{E}-06$ & $4.7 \mathrm{E}-07$ & $5.2 \mathrm{E}-08$ \\
\hline $\mathrm{C}$ & 3.4 & 1359 & $\mathrm{CC}$ & $1.0 \mathrm{E}+00$ & $9.8 \mathrm{E}-01$ & $8.0 \mathrm{E}-01$ & $3.1 \mathrm{E}-01$ & $3.9 \mathrm{E}-02$ & $4.5 \mathrm{E}-03$ & 5.4E-04 & $8.8 \mathrm{E}-05$ & $9.2 \mathrm{E}-06$ & $1.3 \mathrm{E}-06$ & $2.0 \mathrm{E}-07$ \\
\hline $\mathrm{D}$ & 3.4 & 1359 & $\mathrm{CC}$ & $1.0 \mathrm{E}+00$ & $9.9 \mathrm{E}-01$ & $8.8 \mathrm{E}-01$ & $4.5 \mathrm{E}-01$ & $6.9 \mathrm{E}-02$ & $8.3 \mathrm{E}-03$ & $8.7 \mathrm{E}-04$ & $1.7 \mathrm{E}-04$ & $2.4 \mathrm{E}-05$ & $4.3 \mathrm{E}-06$ & $8.3 \mathrm{E}-07$ \\
\hline $\mathrm{E}$ & 3.4 & 1359 & $\mathrm{CC}$ & $1.0 \mathrm{E}+00$ & $1.0 \mathrm{E}+00$ & $9.5 \mathrm{E}-01$ & $6.9 \mathrm{E}-01$ & $1.6 \mathrm{E}-01$ & $2.2 \mathrm{E}-02$ & $2.0 \mathrm{E}-03$ & $3.3 \mathrm{E}-04$ & $5.0 \mathrm{E}-05$ & 9.3E-06 & $2.2 \mathrm{E}-06$ \\
\hline$F$ & 3.4 & 1359 & $\mathrm{CC}$ & $1.0 \mathrm{E}+00$ & $1.0 \mathrm{E}+00$ & $9.8 \mathrm{E}-01$ & $8.6 \mathrm{E}-01$ & 3.6E-01 & $5.8 \mathrm{E}-02$ & $5.7 \mathrm{E}-03$ & 7.0E-04 & $1.2 \mathrm{E}-04$ & $2.5 \mathrm{E}-05$ & $6.1 \mathrm{E}-06$ \\
\hline $\mathrm{C}$ & 10 & 1359 & $\mathrm{CC}$ & $9.9 \mathrm{E}-01$ & $9.4 \mathrm{E}-01$ & $5.8 \mathrm{E}-01$ & $1.3 \mathrm{E}-01$ & $1.3 \mathrm{E}-02$ & $1.5 \mathrm{E}-03$ & $1.8 \mathrm{E}-04$ & $3.0 \mathrm{E}-05$ & $3.1 \mathrm{E}-06$ & $4.4 \mathrm{E}-07$ & $6.7 \mathrm{E}-08$ \\
\hline $\mathrm{D}$ & 10 & 1359 & $\mathrm{CC}$ & $1.0 \mathrm{E}+00$ & $9.7 \mathrm{E}-01$ & $7.1 \mathrm{E}-01$ & $2.2 \mathrm{E}-01$ & $2.5 \mathrm{E}-02$ & $2.8 \mathrm{E}-03$ & $3.0 \mathrm{E}-04$ & $5.9 \mathrm{E}-05$ & $8.1 \mathrm{E}-06$ & $1.5 \mathrm{E}-06$ & $2.8 \mathrm{E}-07$ \\
\hline $\mathrm{E}$ & 10 & 1359 & $\mathrm{CC}$ & $1.0 \mathrm{E}+00$ & $9.9 \mathrm{E}-01$ & $8.7 \mathrm{E}-01$ & 4.3E-01 & $6.3 \mathrm{E}-02$ & 7.4E-03 & $6.9 \mathrm{E}-04$ & $1.1 \mathrm{E}-04$ & $1.7 \mathrm{E}-05$ & $3.2 \mathrm{E}-06$ & $7.5 \mathrm{E}-07$ \\
\hline B & 20 & 1359 & $\mathrm{CC}$ & 9.7E-01 & $7.8 \mathrm{E}-01$ & $2.4 \mathrm{E}-01$ & 3.4E-02 & $3.1 \mathrm{E}-03$ & $3.5 \mathrm{E}-04$ & $5.1 \mathrm{E}-05$ & $6.9 \mathrm{E}-06$ & $6.5 \mathrm{E}-07$ & 7.9E-08 & $8.9 \mathrm{E}-09$ \\
\hline $\mathrm{C}$ & 20 & 1359 & $\mathrm{CC}$ & $9.9 \mathrm{E}-01$ & $8.8 \mathrm{E}-01$ & $4.1 \mathrm{E}-01$ & $7.1 \mathrm{E}-02$ & $6.8 \mathrm{E}-03$ & 7.6E-04 & $9.2 \mathrm{E}-05$ & $1.5 \mathrm{E}-05$ & $1.6 \mathrm{E}-06$ & $2.2 \mathrm{E}-07$ & 3.3E-08 \\
\hline $\mathrm{D}$ & 20 & 1359 & $\mathrm{CC}$ & $9.9 \mathrm{E}-01$ & $9.3 \mathrm{E}-01$ & $5.6 \mathrm{E}-01$ & $1.2 \mathrm{E}-01$ & $1.2 \mathrm{E}-02$ & $1.4 \mathrm{E}-03$ & $1.5 \mathrm{E}-04$ & $2.9 \mathrm{E}-05$ & $4.1 \mathrm{E}-06$ & 7.4E-07 & $1.4 \mathrm{E}-07$ \\
\hline $\mathrm{E}$ & 20 & 1359 & $\mathrm{CC}$ & $1.0 \mathrm{E}+00$ & $9.7 \mathrm{E}-01$ & 7.7E-01 & 2.7E-01 & $3.2 \mathrm{E}-02$ & $3.7 \mathrm{E}-03$ & $3.5 \mathrm{E}-04$ & $5.5 \mathrm{E}-05$ & $8.5 \mathrm{E}-06$ & $1.6 \mathrm{E}-06$ & $3.8 \mathrm{E}-07$ \\
\hline
\end{tabular}


Table A.3. (contd)

\begin{tabular}{|c|c|c|c|c|c|c|c|c|c|c|c|c|c|c|}
\hline \multirow{2}{*}{$\begin{array}{l}\text { Stability } \\
\text { Class }\end{array}$} & \multirow{2}{*}{$\begin{array}{c}\text { Wind } \\
\text { Speed } \\
\mathbf{m} / \mathbf{s}\end{array}$} & \multirow{2}{*}{$\begin{array}{l}\text { Venting } \\
\text { Rate } \\
\text { m3/hr }\end{array}$} & \multirow[b]{2}{*}{ Conc } & \multicolumn{3}{|c|}{ Distance Downwind, $\mathrm{m}$} & \multirow[b]{2}{*}{3} & \multirow[b]{2}{*}{10} & \multirow[b]{2}{*}{30} & \multirow[b]{2}{*}{100} & \multirow[b]{2}{*}{300} & \multirow[b]{2}{*}{1000} & \multirow[b]{2}{*}{3000} & \multirow[b]{2}{*}{10,000} \\
\hline & & & & 0.001 & 0.3 & 1 & & & & & & & & \\
\hline A & 1 & 3398 & $\mathrm{GC}$ & $0.0 \mathrm{E}+00$ & $0.0 \mathrm{E}+00$ & $0.0 \mathrm{E}+00$ & $5.5 \mathrm{E}-16$ & $3.1 \mathrm{E}-03$ & $9.2 \mathrm{E}-03$ & $1.3 \mathrm{E}-03$ & $1.5 \mathrm{E}-04$ & $1.4 \mathrm{E}-05$ & $1.7 \mathrm{E}-06$ & $1.9 \mathrm{E}-07$ \\
\hline B & 1 & 3398 & GC & $0.0 \mathrm{E}+00$ & $0.0 \mathrm{E}+00$ & $0.0 \mathrm{E}+00$ & $2.7 \mathrm{E}-42$ & $2.6 \mathrm{E}-05$ & $9.2 \mathrm{E}-03$ & $2.8 \mathrm{E}-03$ & $3.5 \mathrm{E}-04$ & 3.3E-05 & $4.0 \mathrm{E}-06$ & 4.4E-07 \\
\hline $\mathrm{C}$ & 1 & 3398 & $\overline{\mathrm{GC}}$ & $0.0 \mathrm{E}+00$ & $0.0 \mathrm{E}+00$ & $0.0 \mathrm{E}+00$ & $0.0 \mathrm{E}+00$ & $1.0 \mathrm{E}-09$ & $4.8 \mathrm{E}-03$ & $5.2 \mathrm{E}-03$ & 7.7E-04 & $7.8 \mathrm{E}-05$ & $1.1 \mathrm{E}-05$ & $1.7 \mathrm{E}-06$ \\
\hline $\mathrm{D}$ & 1 & 3398 & GC & $0.0 \mathrm{E}+00$ & $0.0 \mathrm{E}+00$ & $0.0 \mathrm{E}+00$ & $0.0 \mathrm{E}+00$ & $3.0 \mathrm{E}-16$ & $1.3 \mathrm{E}-03$ & 7.6E-03 & $1.6 \mathrm{E}-03$ & $2.0 \mathrm{E}-04$ & $3.7 \mathrm{E}-05$ & 7.1E-06 \\
\hline $\bar{E}$ & 1 & 3398 & GC & $0.0 \mathrm{E}+00$ & $0.0 \mathrm{E}+00$ & $0.0 \mathrm{E}+00$ & $0.0 \mathrm{E}+00$ & $0.0 \mathrm{E}+00$ & $2.9 \mathrm{E}-08$ & $4.9 \mathrm{E}-03$ & $3.1 \mathrm{E}-03$ & $4.4 \mathrm{E}-04$ & $8.0 \mathrm{E}-05$ & $1.9 \mathrm{E}-05$ \\
\hline $\mathrm{F}$ & 1 & 3398 & GC & $0.0 \mathrm{E}+00$ & $0.0 \mathrm{E}+00$ & $0.0 \mathrm{E}+00$ & $0.0 \mathrm{E}+00$ & $0.0 \mathrm{E}+00$ & $7.0 \mathrm{E}-25$ & $2.8 \mathrm{E}-04$ & $4.7 \mathrm{E}-03$ & $1.1 \mathrm{E}-03$ & $2.2 \mathrm{E}-04$ & $5.3 \mathrm{E}-05$ \\
\hline A & 3.4 & 3398 & $\overline{G C}$ & $0.0 \mathrm{E}+00$ & $0.0 \mathrm{E}+00$ & $0.0 \mathrm{E}+00$ & $2.3 \mathrm{E}-16$ & $9.5 \mathrm{E}-04$ & $2.7 \mathrm{E}-03$ & 3.9E-04 & $4.5 \mathrm{E}-05$ & $4.2 \mathrm{E}-06$ & $5.1 \mathrm{E}-07$ & $5.7 \mathrm{E}-08$ \\
\hline B & 3.4 & 3398 & GC & $0.0 \mathrm{E}+00$ & $0.0 \mathrm{E}+00$ & $0.0 \mathrm{E}+00$ & $1.4 \mathrm{E}-42$ & $8.3 \mathrm{E}-06$ & $2.7 \mathrm{E}-03$ & $8.1 \mathrm{E}-04$ & $1.0 \mathrm{E}-04$ & $9.6 \mathrm{E}-06$ & $1.2 \mathrm{E}-06$ & $1.3 \mathrm{E}-07$ \\
\hline $\mathrm{C}$ & 3.4 & 3398 & $\mathrm{GC}$ & $0.0 \mathrm{E}+00$ & $0.0 \mathrm{E}+00$ & $0.0 \mathrm{E}+00$ & $0.0 \mathrm{E}+00$ & $3.7 \mathrm{E}-10$ & $1.4 \mathrm{E}-03$ & $1.5 \mathrm{E}-03$ & $2.3 \mathrm{E}-04$ & $2.3 \mathrm{E}-05$ & $3.2 \mathrm{E}-06$ & $4.9 \mathrm{E}-07$ \\
\hline $\mathrm{D}$ & 3.4 & 3398 & GC & $0.0 \mathrm{E}+00$ & $0.0 \mathrm{E}+00$ & $0.0 \mathrm{E}+00$ & $0.0 \mathrm{E}+00$ & $1.2 \mathrm{E}-16$ & $3.9 \mathrm{E}-04$ & $2.2 \mathrm{E}-03$ & 4.6E-04 & $6.0 \mathrm{E}-05$ & $1.1 \mathrm{E}-05$ & $2.1 \mathrm{E}-06$ \\
\hline $\mathrm{E}$ & 3.4 & 3398 & $\mathrm{GC}$ & $0.0 \mathrm{E}+00$ & $0.0 \mathrm{E}+00$ & $0.0 \mathrm{E}+00$ & $0.0 \mathrm{E}+00$ & $0.0 \mathrm{E}+00$ & $9.5 \mathrm{E}-09$ & $1.5 \mathrm{E}-03$ & $9.3 \mathrm{E}-04$ & $1.3 \mathrm{E}-04$ & $2.3 \mathrm{E}-05$ & $5.5 \mathrm{E}-06$ \\
\hline $\mathrm{F}$ & 3.4 & 3398 & GC & $0.0 \mathrm{E}+00$ & $0.0 \mathrm{E}+00$ & $0.0 \mathrm{E}+00$ & $0.0 \mathrm{E}+00$ & $0.0 \mathrm{E}+00$ & 2.7E-25 & $8.5 \mathrm{E}-05$ & $1.4 \mathrm{E}-03$ & 3.3E-04 & $6.5 \mathrm{E}-05$ & $1.5 \mathrm{E}-05$ \\
\hline G & 3.4 & 3398 & GC & $0.0 \mathrm{E}+00$ & $0.0 \mathrm{E}+00$ & $0.0 \mathrm{E}+00$ & $0.0 \mathrm{E}+00$ & $0.0 \mathrm{E}+00$ & $0.0 \mathrm{E}+00$ & 5.1E-10 & $5.5 \mathrm{E}-04$ & $6.9 \mathrm{E}-04$ & $1.7 \mathrm{E}-04$ & 4.2E-05 \\
\hline $\mathrm{C}$ & 10 & 3398 & GC & $0.0 \mathrm{E}+00$ & $0.0 \mathrm{E}+00$ & $0.0 \mathrm{E}+00$ & $0.0 \mathrm{E}+00$ & $1.3 \mathrm{E}-10$ & $4.9 \mathrm{E}-04$ & $5.2 \mathrm{E}-04$ & 7.7E-05 & $7.8 \mathrm{E}-06$ & $1.1 \mathrm{E}-06$ & $1.7 \mathrm{E}-07$ \\
\hline $\mathrm{D}$ & 10 & 3398 & GC & $0.0 \mathrm{E}+00$ & $0.0 \mathrm{E}+00$ & $0.0 \mathrm{E}+00$ & $0.0 \mathrm{E}+00$ & $4.5 \mathrm{E}-17$ & $1.3 \mathrm{E}-04$ & 7.6E-04 & $1.6 \mathrm{E}-04$ & $2.0 \mathrm{E}-05$ & $3.7 \mathrm{E}-06$ & $7.1 \mathrm{E}-07$ \\
\hline$E$ & 10 & 3398 & GC & $0.0 \mathrm{E}+00$ & $0.0 \mathrm{E}+00$ & $0.0 \mathrm{E}+00$ & $0.0 \mathrm{E}+00$ & $0.0 \mathrm{E}+00$ & $3.4 \mathrm{E}-09$ & $5.0 \mathrm{E}-04$ & $3.1 \mathrm{E}-04$ & $4.4 \mathrm{E}-05$ & $8.0 \mathrm{E}-06$ & $1.9 \mathrm{E}-06$ \\
\hline C & 20 & 3398 & GC & $0.0 \mathrm{E}+00$ & $0.0 \mathrm{E}+00$ & $0.0 \mathrm{E}+00$ & $0.0 \mathrm{E}+00$ & $6.8 \mathrm{E}-11$ & $2.5 \mathrm{E}-04$ & $2.6 \mathrm{E}-04$ & $3.8 \mathrm{E}-05$ & $3.9 \mathrm{E}-06$ & $5.5 \mathrm{E}-07$ & $8.4 \mathrm{E}-08$ \\
\hline $\mathrm{D}$ & 20 & 3398 & GC & $0.0 \mathrm{E}+00$ & $0.0 \mathrm{E}+00$ & $0.0 \mathrm{E}+00$ & $0.0 \mathrm{E}+00$ & $2.3 \mathrm{E}-17$ & $6.8 \mathrm{E}-05$ & $3.8 \mathrm{E}-04$ & $7.8 \mathrm{E}-05$ & $1.0 \mathrm{E}-05$ & $1.9 \mathrm{E}-06$ & $3.5 \mathrm{E}-07$ \\
\hline$E$ & 20 & 3398 & $\mathrm{GC}$ & $0.0 \mathrm{E}+00$ & $0.0 \mathrm{E}+00$ & $0.0 \mathrm{E}+00$ & $0.0 \mathrm{E}+00$ & $0.0 \mathrm{E}+00$ & $1.7 \mathrm{E}-09$ & $2.5 \mathrm{E}-04$ & $1.6 \mathrm{E}-04$ & $2.2 \mathrm{E}-05$ & $4.0 \mathrm{E}-06$ & $9.4 \mathrm{E}-07$ \\
\hline
\end{tabular}


Table A.3. (contd)

\begin{tabular}{|c|c|c|c|c|c|c|c|c|c|c|c|c|c|c|}
\hline \multirow{2}{*}{$\begin{array}{c}\text { Stability } \\
\text { Class }\end{array}$} & \multirow{2}{*}{$\begin{array}{l}\text { Wind } \\
\text { Speed } \\
\mathrm{m} / \mathrm{s}\end{array}$} & \multirow{2}{*}{$\begin{array}{c}\text { Venting } \\
\text { Rate } \\
\text { m3/hr }\end{array}$} & \multirow[b]{2}{*}{ Conc } & \multicolumn{3}{|c|}{ Distance Downwind, $\mathbf{m}$} & \multirow[b]{2}{*}{3} & \multirow[b]{2}{*}{10} & \multirow[b]{2}{*}{30} & \multirow[b]{2}{*}{100} & \multirow[b]{2}{*}{300} & \multirow[b]{2}{*}{1000} & \multirow[b]{2}{*}{3000} & \multirow[b]{2}{*}{10,000} \\
\hline & & & & 0.001 & 0.3 & 1 & & & & & & & & \\
\hline A & 1 & 3398 & $\mathrm{CC}$ & $1.0 \mathrm{E}+00$ & $9.9 \mathrm{E}-01$ & $8.7 \mathrm{E}-01$ & $4.3 \mathrm{E}-01$ & $6.4 \mathrm{E}-02$ & $8.6 \mathrm{E}-03$ & $1.3 \mathrm{E}-03$ & $1.5 \mathrm{E}-04$ & $1.4 \mathrm{E}-05$ & $1.7 \mathrm{E}-06$ & $1.9 \mathrm{E}-07$ \\
\hline B & 1 & 3398 & $\mathrm{CC}$ & $1.0 \mathrm{E}+00$ & $9.9 \mathrm{E}-01$ & $9.4 \mathrm{E}-01$ & $6.3 \mathrm{E}-01$ & $1.4 \mathrm{E}-01$ & $1.7 \mathrm{E}-02$ & $2.5 \mathrm{E}-03$ & $3.4 \mathrm{E}-04$ & $3.3 \mathrm{E}-05$ & $4.0 \mathrm{E}-06$ & $4.4 \mathrm{E}-07$ \\
\hline $\mathrm{C}$ & 1 & 3398 & $\mathrm{CC}$ & $1.0 \mathrm{E}+00$ & $1.0 \mathrm{E}+00$ & $9.7 \mathrm{E}-01$ & 7.9E-01 & $2.5 \mathrm{E}-01$ & $3.7 \mathrm{E}-02$ & $4.6 \mathrm{E}-03$ & 7.4E-04 & $7.8 \mathrm{E}-05$ & $1.1 \mathrm{E}-05$ & $1.7 \mathrm{E}-06$ \\
\hline $\mathrm{D}$ & 1 & 3398 & $\mathrm{CC}$ & $1.0 \mathrm{E}+00$ & $1.0 \mathrm{E}+00$ & $9.8 \mathrm{E}-01$ & 8.7E-01 & $3.9 \mathrm{E}-01$ & $6.6 \mathrm{E}-02$ & 7.4E-03 & $1.5 \mathrm{E}-03$ & $2.0 \mathrm{E}-04$ & $3.7 \mathrm{E}-05$ & 7.1E-06 \\
\hline $\bar{E}$ & 1 & 3398 & $\mathrm{CC}$ & $1.0 \mathrm{E}+00$ & $1.0 \mathrm{E}+00$ & $9.9 \mathrm{E}-01$ & $9.5 \mathrm{E}-01$ & 6.3E-01 & $1.6 \mathrm{E}-01$ & $1.7 \mathrm{E}-02$ & $2.8 \mathrm{E}-03$ & $4.3 \mathrm{E}-04$ & 7.9E-05 & $1.9 \mathrm{E}-05$ \\
\hline$F$ & 1 & 3398 & $\mathrm{CC}$ & $1.0 \mathrm{E}+00$ & $1.0 \mathrm{E}+00$ & $1.0 \mathrm{E}+00$ & $9.8 \mathrm{E}-01$ & $8.2 \mathrm{E}-01$ & $3.5 \mathrm{E}-01$ & $4.6 \mathrm{E}-02$ & $5.9 \mathrm{E}-03$ & $1.0 \mathrm{E}-03$ & $2.1 \mathrm{E}-04$ & $5.2 \mathrm{E}-05$ \\
\hline A & 3.4 & 3398 & $\mathrm{CC}$ & $1.0 \mathrm{E}+00$ & $9.6 \mathrm{E}-01$ & $6.7 \mathrm{E}-01$ & $1.8 \mathrm{E}-01$ & $2.0 \mathrm{E}-02$ & $2.5 \mathrm{E}-03$ & 3.7E-04 & $4.5 \mathrm{E}-05$ & $4.2 \mathrm{E}-06$ & $5.1 \mathrm{E}-07$ & 5.7E-08 \\
\hline B & 3.4 & 3398 & $\mathrm{CC}$ & $1.0 \mathrm{E}+00$ & $9.8 \mathrm{E}-01$ & $8.2 \mathrm{E}-01$ & 3.4E-01 & $4.4 \mathrm{E}-02$ & $5.1 \mathrm{E}-03$ & 7.4E-04 & $1.0 \mathrm{E}-04$ & $9.6 \mathrm{E}-06$ & $1.2 \mathrm{E}-06$ & $1.3 \mathrm{E}-07$ \\
\hline $\mathrm{C}$ & 3.4 & 3398 & $\mathrm{CC}$ & $1.0 \mathrm{E}+00$ & $9.9 \mathrm{E}-01$ & $9.1 \mathrm{E}-01$ & 5.3E-01 & $9.1 \mathrm{E}-02$ & $1.1 \mathrm{E}-02$ & $1.3 \mathrm{E}-03$ & $2.2 \mathrm{E}-04$ & $2.3 \mathrm{E}-05$ & $3.2 \mathrm{E}-06$ & $4.9 \mathrm{E}-07$ \\
\hline $\mathrm{D}$ & 3.4 & 3398 & $\mathrm{CC}$ & $1.0 \mathrm{E}+00$ & $1.0 \mathrm{E}+00$ & $9.5 \mathrm{E}-01$ & $6.7 \mathrm{E}-01$ & $1.6 \mathrm{E}-01$ & $2.1 \mathrm{E}-02$ & $2.2 \mathrm{E}-03$ & $4.3 \mathrm{E}-04$ & $6.0 \mathrm{E}-05$ & $1.1 \mathrm{E}-05$ & $2.1 \mathrm{E}-06$ \\
\hline $\mathrm{E}$ & 3.4 & 3398 & $\mathrm{CC}$ & $1.0 \mathrm{E}+00$ & $1.0 \mathrm{E}+00$ & $9.8 \mathrm{E}-01$ & $8.5 \mathrm{E}-01$ & 3.3E-01 & $5.2 \mathrm{E}-02$ & $5.1 \mathrm{E}-03$ & $8.2 \mathrm{E}-04$ & $1.3 \mathrm{E}-04$ & $2.3 \mathrm{E}-05$ & $5.5 \mathrm{E}-06$ \\
\hline $\mathrm{F}$ & 3.4 & 3398 & $\mathrm{CC}$ & $1.0 \mathrm{E}+00$ & $1.0 \mathrm{E}+00$ & $9.9 \mathrm{E}-01$ & 9.4E-01 & $5.8 \mathrm{E}-01$ & $1.3 \mathrm{E}-01$ & $1.4 \mathrm{E}-02$ & $1.7 \mathrm{E}-03$ & $3.1 \mathrm{E}-04$ & $6.3 \mathrm{E}-05$ & $1.5 \mathrm{E}-05$ \\
\hline$G$ & 3.4 & 3398 & $\mathrm{CC}$ & $1.0 \mathrm{E}+00$ & $1.0 \mathrm{E}+00$ & $1.0 \mathrm{E}+00$ & $9.8 \mathrm{E}-01$ & 7.9E-01 & $3.0 \mathrm{E}-01$ & $3.8 \mathrm{E}-02$ & $4.7 \mathrm{E}-03$ & $6.2 \mathrm{E}-04$ & $1.6 \mathrm{E}-04$ & $4.0 \mathrm{E}-05$ \\
\hline $\mathrm{C}$ & 10 & 3398 & $\mathrm{CC}$ & $1.0 \mathrm{E}+00$ & $9.7 \mathrm{E}-01$ & 7.7E-01 & $2.8 \mathrm{E}-01$ & $3.3 \mathrm{E}-02$ & $3.8 \mathrm{E}-03$ & 4.6E-04 & 7.4E-05 & $7.8 \mathrm{E}-06$ & $1.1 \mathrm{E}-06$ & $1.7 \mathrm{E}-07$ \\
\hline $\mathrm{D}$ & 10 & 3398 & $\overline{C C}$ & $1.0 \mathrm{E}+00$ & $9.9 \mathrm{E}-01$ & $8.6 \mathrm{E}-01$ & $4.1 \mathrm{E}-01$ & $5.9 \mathrm{E}-02$ & 7.1E-03 & 7.4E-04 & $1.5 \mathrm{E}-04$ & $2.0 \mathrm{E}-05$ & $3.7 \mathrm{E}-06$ & $7.1 \mathrm{E}-07$ \\
\hline$E$ & 10 & 3398 & $\mathrm{CC}$ & $1.0 \mathrm{E}+00$ & $9.9 \mathrm{E}-01$ & $9.4 \mathrm{E}-01$ & $6.5 \mathrm{E}-01$ & $1.4 \mathrm{E}-01$ & $1.8 \mathrm{E}-02$ & $1.7 \mathrm{E}-03$ & $2.8 \mathrm{E}-04$ & $4.3 \mathrm{E}-05$ & $7.9 \mathrm{E}-06$ & $1.9 \mathrm{E}-06$ \\
\hline $\bar{C}$ & 20 & 3398 & $\mathrm{CC}$ & $9.9 \mathrm{E}-01$ & $9.5 \mathrm{E}-01$ & $6.3 \mathrm{E}-01$ & $1.6 \mathrm{E}-01$ & $1.7 \mathrm{E}-02$ & $1.9 \mathrm{E}-03$ & $2.3 \mathrm{E}-04$ & $3.7 \mathrm{E}-05$ & $3.9 \mathrm{E}-06$ & $5.5 \mathrm{E}-07$ & $8.4 \mathrm{E}-08$ \\
\hline $\mathrm{D}$ & 20 & 3398 & $\mathrm{CC}$ & $1.0 \mathrm{E}+00$ & $9.7 \mathrm{E}-01$ & 7.6E-01 & $2.6 \mathrm{E}-01$ & $3.1 \mathrm{E}-02$ & $3.5 \mathrm{E}-03$ & 3.7E-04 & 7.3E-05 & $1.0 \mathrm{E}-05$ & $1.8 \mathrm{E}-06$ & $3.5 \mathrm{E}-07$ \\
\hline $\bar{E}$ & 20 & 3398 & $\overline{\mathrm{CC}}$ & $1.0 \mathrm{E}+00$ & $9.9 \mathrm{E}-01$ & $8.9 \mathrm{E}-01$ & $4.8 \mathrm{E}-01$ & 7.7E-02 & $9.3 \mathrm{E}-03$ & $8.6 \mathrm{E}-04$ & $1.4 \mathrm{E}-04$ & $2.1 \mathrm{E}-05$ & $4.0 \mathrm{E}-06$ & $9.4 \mathrm{E}-07$ \\
\hline
\end{tabular}


Table A.4. AW Farm Existing Vent; Fractional Concentrations at Ground Level (GC) and Plume Centerline (CC)

\begin{tabular}{|c|c|c|c|c|c|c|c|c|c|c|c|c|c|c|}
\hline \multirow{2}{*}{$\begin{array}{c}\text { Stability } \\
\text { Class }\end{array}$} & \multirow{2}{*}{$\begin{array}{c}\text { Wind } \\
\text { Speed } \\
\mathrm{m} / \mathrm{s}\end{array}$} & \multirow{2}{*}{$\begin{array}{c}\text { Venting } \\
\text { Rate } \\
\text { m3/hr }\end{array}$} & \multirow[b]{2}{*}{ Conc } & \multicolumn{3}{|c|}{ Distance Downwind, m } & \multirow[b]{2}{*}{3} & \multirow[b]{2}{*}{10} & \multirow[b]{2}{*}{30} & \multirow[b]{2}{*}{100} & \multirow[b]{2}{*}{300} & \multirow[b]{2}{*}{1000} & \multirow[b]{2}{*}{3000} & \multirow[b]{2}{*}{10,000} \\
\hline & & & & 0.001 & 0.3 & 1 & & & & & & & & \\
\hline A & 1 & 1699 & $\mathrm{GC}$ & $0.0 \mathrm{E}+00$ & $0.0 \mathrm{E}+00$ & $0.0 \mathrm{E}+00$ & $4.5 \mathrm{E}-10$ & $5.8 \mathrm{E}-03$ & $5.5 \mathrm{E}-03$ & 6.7E-04 & 7.7E-05 & $7.2 \mathrm{E}-06$ & 8.7E-07 & 9.7E-08 \\
\hline B & 1 & 1699 & GC & $0.0 \mathrm{E}+00$ & $0.0 \mathrm{E}+00$ & $0.0 \mathrm{E}+00$ & $1.9 \mathrm{E}-25$ & $4.6 \mathrm{E}-04$ & 7.3E-03 & $1.4 \mathrm{E}-03$ & $1.7 \mathrm{E}-04$ & $1.6 \mathrm{E}-05$ & $2.0 \mathrm{E}-06$ & 2.2E-07 \\
\hline $\mathrm{C}$ & 1 & 1699 & GC & $0.0 \mathrm{E}+00$ & $0.0 \mathrm{E}+00$ & $0.0 \mathrm{E}+00$ & $0.0 \mathrm{E}+00$ & $1.6 \mathrm{E}-06$ & $6.2 \mathrm{E}-03$ & $2.9 \mathrm{E}-03$ & $3.9 \mathrm{E}-04$ & $3.9 \mathrm{E}-05$ & $5.5 \mathrm{E}-06$ & $8.4 \mathrm{E}-07$ \\
\hline $\mathrm{D}$ & 1 & 1699 & GC & $0.0 \mathrm{E}+00$ & $0.0 \mathrm{E}+00$ & $0.0 \mathrm{E}+00$ & $0.0 \mathrm{E}+00$ & $2.9 \mathrm{E}-10$ & $3.4 \mathrm{E}-03$ & 4.6E-03 & 8.1E-04 & $1.0 \mathrm{E}-04$ & $1.9 \mathrm{E}-05$ & $3.5 \mathrm{E}-06$ \\
\hline $\mathrm{E}$ & 1 & 1699 & GC & $0.0 \mathrm{E}+00$ & $0.0 \mathrm{E}+00$ & $0.0 \mathrm{E}+00$ & $0.0 \mathrm{E}+00$ & $2.1 \mathrm{E}-36$ & $9.1 \mathrm{E}-06$ & $4.8 \mathrm{E}-03$ & $1.7 \mathrm{E}-03$ & $2.2 \mathrm{E}-04$ & $4.0 \mathrm{E}-05$ & $9.4 \mathrm{E}-06$ \\
\hline $\mathrm{F}$ & 1 & 1699 & GC & $0.0 \mathrm{E}+00$ & $0.0 \mathrm{E}+00$ & $0.0 \mathrm{E}+00$ & $0.0 \mathrm{E}+00$ & $0.0 \mathrm{E}+00$ & $2.2 \mathrm{E}-15$ & $1.2 \mathrm{E}-03$ & $3.2 \mathrm{E}-03$ & $5.9 \mathrm{E}-04$ & $1.1 \mathrm{E}-04$ & $2.6 \mathrm{E}-05$ \\
\hline A & 3.4 & 1699 & GC & $0.0 \mathrm{E}+00$ & $0.0 \mathrm{E}+00$ & $0.0 \mathrm{E}+00$ & $1.7 \mathrm{E}-10$ & $1.8 \mathrm{E}-03$ & $1.6 \mathrm{E}-03$ & $2.0 \mathrm{E}-04$ & $2.3 \mathrm{E}-05$ & $2.1 \mathrm{E}-06$ & $2.5 \mathrm{E}-07$ & $2.8 \mathrm{E}-08$ \\
\hline B & 3.4 & 1699 & GC & $0.0 \mathrm{E}+00$ & $0.0 \mathrm{E}+00$ & $0.0 \mathrm{E}+00$ & $8.2 \mathrm{E}-26$ & $1.4 \mathrm{E}-04$ & $2.1 \mathrm{E}-03$ & $4.3 \mathrm{E}-04$ & $5.1 \mathrm{E}-05$ & $4.8 \mathrm{E}-06$ & $5.8 \mathrm{E}-07$ & $6.5 \mathrm{E}-08$ \\
\hline $\mathrm{C}$ & 3.4 & 1699 & GC & $0.0 \mathrm{E}+00$ & $0.0 \mathrm{E}+00$ & $0.0 \mathrm{E}+00$ & $0.0 \mathrm{E}+00$ & $5.4 \mathrm{E}-07$ & $1.9 \mathrm{E}-03$ & 8.4E-04 & $1.1 \mathrm{E}-04$ & $1.2 \mathrm{E}-05$ & $1.6 \mathrm{E}-06$ & $2.5 \mathrm{E}-07$ \\
\hline $\mathrm{D}$ & 3.4 & 1699 & GC & $0.0 \mathrm{E}+00$ & $0.0 \mathrm{E}+00$ & $0.0 \mathrm{E}+00$ & $0.0 \mathrm{E}+00$ & $1.0 \mathrm{E}-10$ & $1.0 \mathrm{E}-03$ & $1.4 \mathrm{E}-03$ & $2.4 \mathrm{E}-04$ & $3.0 \mathrm{E}-05$ & $5.5 \mathrm{E}-06$ & $1.0 \mathrm{E}-06$ \\
\hline $\mathrm{E}$ & 3.4 & 1699 & GC & $0.0 \mathrm{E}+00$ & $0.0 \mathrm{E}+00$ & $0.0 \mathrm{E}+00$ & $0.0 \mathrm{E}+00$ & $9.0 \mathrm{E}-37$ & $2.8 \mathrm{E}-06$ & $1.4 \mathrm{E}-03$ & $5.1 \mathrm{E}-04$ & $6.5 \mathrm{E}-05$ & $1.2 \mathrm{E}-05$ & $2.8 \mathrm{E}-06$ \\
\hline $\mathrm{F}$ & 3.4 & 1699 & GC & $0.0 \mathrm{E}+00$ & $0.0 \mathrm{E}+00$ & $0.0 \mathrm{E}+00$ & $0.0 \mathrm{E}+00$ & $0.0 \mathrm{E}+00$ & $7.7 \mathrm{E}-16$ & $3.5 \mathrm{E}-04$ & $9.4 \mathrm{E}-04$ & $1.7 \mathrm{E}-04$ & $3.3 \mathrm{E}-05$ & $7.8 \mathrm{E}-06$ \\
\hline G & 3.4 & 1699 & GC & $0.0 \mathrm{E}+00$ & $0.0 \mathrm{E}+00$ & $0.0 \mathrm{E}+00$ & $0.0 \mathrm{E}+00$ & $0.0 \mathrm{E}+00$ & $0.0 \mathrm{E}+00$ & 4.4E-07 & 7.3E-04 & $4.0 \mathrm{E}-04$ & 8.7E-05 & 2.1E-05 \\
\hline $\mathrm{C}$ & 10 & 1699 & GC & $0.0 \mathrm{E}+00$ & $0.0 \mathrm{E}+00$ & $0.0 \mathrm{E}+00$ & $0.0 \mathrm{E}+00$ & $1.9 \mathrm{E}-07$ & $6.3 \mathrm{E}-04$ & $2.9 \mathrm{E}-04$ & $3.9 \mathrm{E}-05$ & $3.9 \mathrm{E}-06$ & $5.5 \mathrm{E}-07$ & $8.4 \mathrm{E}-08$ \\
\hline $\mathrm{D}$ & 10 & 1699 & GC & $0.0 \mathrm{E}+00$ & $0.0 \mathrm{E}+00$ & $0.0 \mathrm{E}+00$ & $0.0 \mathrm{E}+00$ & $3.7 \mathrm{E}-11$ & $3.5 \mathrm{E}-04$ & 4.6E-04 & $8.1 \mathrm{E}-05$ & $1.0 \mathrm{E}-05$ & $1.9 \mathrm{E}-06$ & $3.5 \mathrm{E}-07$ \\
\hline$E$ & 10 & 1699 & GC & $0.0 \mathrm{E}+00$ & $0.0 \mathrm{E}+00$ & $0.0 \mathrm{E}+00$ & $0.0 \mathrm{E}+00$ & $3.5 \mathrm{E}-37$ & $9.9 \mathrm{E}-07$ & $4.8 \mathrm{E}-04$ & $1.7 \mathrm{E}-04$ & $2.2 \mathrm{E}-05$ & $4.0 \mathrm{E}-06$ & 9.4E-07 \\
\hline $\mathrm{C}$ & 20 & 1699 & GC & $0.0 \mathrm{E}+00$ & $0.0 \mathrm{E}+00$ & $0.0 \mathrm{E}+00$ & $0.0 \mathrm{E}+00$ & $9.5 \mathrm{E}-08$ & $3.2 \mathrm{E}-04$ & $1.4 \mathrm{E}-04$ & $1.9 \mathrm{E}-05$ & $2.0 \mathrm{E}-06$ & $2.7 \mathrm{E}-07$ & $4.2 \mathrm{E}-08$ \\
\hline $\mathrm{D}$ & 20 & 1699 & GC & $0.0 \mathrm{E}+00$ & $0.0 \mathrm{E}+00$ & $0.0 \mathrm{E}+00$ & $0.0 \mathrm{E}+00$ & $1.9 \mathrm{E}-11$ & $1.8 \mathrm{E}-04$ & $2.3 \mathrm{E}-04$ & $4.0 \mathrm{E}-05$ & $5.1 \mathrm{E}-06$ & $9.3 \mathrm{E}-07$ & $1.8 \mathrm{E}-07$ \\
\hline$E$ & 20 & 1699 & GC & $0.0 \mathrm{E}+00$ & $0.0 \mathrm{E}+00$ & $0.0 \mathrm{E}+00$ & $0.0 \mathrm{E}+00$ & $1.8 \mathrm{E}-37$ & $5.0 \mathrm{E}-07$ & $2.4 \mathrm{E}-04$ & $8.6 \mathrm{E}-05$ & $1.1 \mathrm{E}-05$ & $2.0 \mathrm{E}-06$ & 4.7E-07 \\
\hline
\end{tabular}


Table A.4. (contd)

\begin{tabular}{|c|c|c|c|c|c|c|c|c|c|c|c|c|c|c|}
\hline \multirow{2}{*}{$\begin{array}{c}\text { Stability } \\
\text { Class }\end{array}$} & \multirow{2}{*}{$\begin{array}{l}\text { Wind } \\
\text { Speed } \\
\mathrm{m} / \mathrm{s}\end{array}$} & \multirow{2}{*}{$\begin{array}{c}\text { Venting } \\
\text { Rate } \\
\text { m3/hr }\end{array}$} & \multirow[b]{2}{*}{ Conc. } & \multicolumn{3}{|c|}{ Distance Downwind, $\mathbf{m}$} & \multirow[b]{2}{*}{3} & \multirow[b]{2}{*}{10} & \multirow[b]{2}{*}{30} & \multirow[b]{2}{*}{100} & \multirow[b]{2}{*}{300} & \multirow[b]{2}{*}{1000} & \multirow[b]{2}{*}{3000} & \multirow[b]{2}{*}{10,000} \\
\hline & & & & 0.001 & 0.3 & 1 & & & & & & & & \\
\hline A & 1 & 1699 & $\mathrm{CC}$ & $1.0 \mathrm{E}+00$ & $9.7 \mathrm{E}-01$ & 7.7E-01 & $2.8 \mathrm{E}-01$ & $3.3 \mathrm{E}-02$ & $4.8 \mathrm{E}-03$ & $6.5 \mathrm{E}-04$ & 7.7E-05 & 7.2E-06 & 8.7E-07 & 9.7E-08 \\
\hline B & 1 & 1699 & $\mathrm{CC}$ & $1.0 \mathrm{E}+00$ & $9.9 \mathrm{E}-01$ & $8.9 \mathrm{E}-01$ & 4.7E-01 & $7.3 \mathrm{E}-02$ & $8.9 \mathrm{E}-03$ & $1.4 \mathrm{E}-03$ & $1.7 \mathrm{E}-04$ & $1.6 \mathrm{E}-05$ & $2.0 \mathrm{E}-06$ & $2.2 \mathrm{E}-07$ \\
\hline $\mathrm{C}$ & 1 & 1699 & $\mathrm{CC}$ & $1.0 \mathrm{E}+00$ & $9.9 \mathrm{E}-01$ & $9.4 \mathrm{E}-01$ & $6.5 \mathrm{E}-01$ & $1.5 \mathrm{E}-01$ & $1.9 \mathrm{E}-02$ & $2.6 \mathrm{E}-03$ & $3.8 \mathrm{E}-04$ & $3.9 \mathrm{E}-05$ & $5.5 \mathrm{E}-06$ & $8.4 \mathrm{E}-07$ \\
\hline $\mathrm{D}$ & 1 & 1699 & $\mathrm{CC}$ & $1.0 \mathrm{E}+00$ & $1.0 \mathrm{E}+00$ & $9.7 \mathrm{E}-01$ & 7.8E-01 & $2.4 \mathrm{E}-01$ & $3.4 \mathrm{E}-02$ & $4.1 \mathrm{E}-03$ & 7.7E-04 & $1.0 \mathrm{E}-04$ & $1.9 \mathrm{E}-05$ & $3.5 \mathrm{E}-06$ \\
\hline $\bar{E}$ & 1 & 1699 & $\mathrm{CC}$ & $1.0 \mathrm{E}+00$ & $1.0 \mathrm{E}+00$ & $9.9 \mathrm{E}-01$ & $9.0 \mathrm{E}-01$ & 4.6E-01 & $8.6 \mathrm{E}-02$ & $8.6 \mathrm{E}-03$ & $1.5 \mathrm{E}-03$ & 2.2E-04 & $4.0 \mathrm{E}-05$ & $9.4 \mathrm{E}-06$ \\
\hline$F$ & 1 & 1699 & $\mathrm{CC}$ & $1.0 \mathrm{E}+00$ & $1.0 \mathrm{E}+00$ & $1.0 \mathrm{E}+00$ & $9.6 \mathrm{E}-01$ & $7.0 \mathrm{E}-01$ & $2.1 \mathrm{E}-01$ & $2.4 \mathrm{E}-02$ & $3.1 \mathrm{E}-03$ & $5.6 \mathrm{E}-04$ & $1.1 \mathrm{E}-04$ & $2.6 \mathrm{E}-05$ \\
\hline A & 3.4 & 1699 & $\mathrm{CC}$ & $9.9 \mathrm{E}-01$ & $9.2 \mathrm{E}-01$ & $5.0 \mathrm{E}-01$ & $1.0 \mathrm{E}-01$ & $9.9 \mathrm{E}-03$ & $1.4 \mathrm{E}-03$ & $1.9 \mathrm{E}-04$ & $2.3 \mathrm{E}-05$ & $2.1 \mathrm{E}-06$ & $2.5 \mathrm{E}-07$ & $2.8 \mathrm{E}-08$ \\
\hline B & 3.4 & 1699 & $\mathrm{CC}$ & $1.0 \mathrm{E}+00$ & $9.6 \mathrm{E}-01$ & $7.0 \mathrm{E}-01$ & $2.0 \mathrm{E}-01$ & $2.3 \mathrm{E}-02$ & $2.6 \mathrm{E}-03$ & $4.0 \mathrm{E}-04$ & $5.1 \mathrm{E}-05$ & $4.8 \mathrm{E}-06$ & $5.8 \mathrm{E}-07$ & $6.5 \mathrm{E}-08$ \\
\hline C & 3.4 & 1699 & $\overline{\mathrm{CC}}$ & $1.0 \mathrm{E}+00$ & $9.8 \mathrm{E}-01$ & $8.3 \mathrm{E}-01$ & 3.6E-01 & $4.8 \mathrm{E}-02$ & 5.6E-03 & $7.5 \mathrm{E}-04$ & $1.1 \mathrm{E}-04$ & $1.1 \mathrm{E}-05$ & $1.6 \mathrm{E}-06$ & $2.5 \mathrm{E}-07$ \\
\hline $\mathrm{D}$ & 3.4 & 1699 & $\mathrm{CC}$ & $1.0 \mathrm{E}+00$ & $9.9 \mathrm{E}-01$ & $9.0 \mathrm{E}-01$ & $5.1 \mathrm{E}-01$ & $8.5 \mathrm{E}-02$ & $1.0 \mathrm{E}-02$ & $1.2 \mathrm{E}-03$ & $2.3 \mathrm{E}-04$ & $3.0 \mathrm{E}-05$ & $5.4 \mathrm{E}-06$ & $1.0 \mathrm{E}-06$ \\
\hline $\mathrm{E}$ & 3.4 & 1699 & $\mathrm{CC}$ & $1.0 \mathrm{E}+00$ & $9.9 \mathrm{E}-01$ & 9.6E-01 & 7.3E-01 & $2.0 \mathrm{E}-01$ & $2.7 \mathrm{E}-02$ & $2.5 \mathrm{E}-03$ & $4.5 \mathrm{E}-04$ & $6.4 \mathrm{E}-05$ & $1.2 \mathrm{E}-05$ & $2.8 \mathrm{E}-06$ \\
\hline $\mathrm{F}$ & 3.4 & 1699 & $\mathrm{CC}$ & $1.0 \mathrm{E}+00$ & $1.0 \mathrm{E}+00$ & $9.9 \mathrm{E}-01$ & $8.8 \mathrm{E}-01$ & $4.1 \mathrm{E}-01$ & 7.2E-02 & $7.1 \mathrm{E}-03$ & 9.3E-04 & $1.6 \mathrm{E}-04$ & $3.2 \mathrm{E}-05$ & 7.7E-06 \\
\hline$G$ & 3.4 & 1699 & $\mathrm{CC}$ & $1.0 \mathrm{E}+00$ & $1.0 \mathrm{E}+00$ & $9.9 \mathrm{E}-01$ & 9.6E-01 & $6.6 \mathrm{E}-01$ & $1.8 \mathrm{E}-01$ & $2.0 \mathrm{E}-02$ & $2.4 \mathrm{E}-03$ & $3.5 \mathrm{E}-04$ & $8.2 \mathrm{E}-05$ & $2.1 \mathrm{E}-05$ \\
\hline $\mathrm{C}$ & 10 & 1699 & $\mathrm{CC}$ & $9.9 \mathrm{E}-01$ & $9.5 \mathrm{E}-01$ & 6.3E-01 & 1.6E-01 & $1.7 \mathrm{E}-02$ & $1.9 \mathrm{E}-03$ & 2.6E-04 & $3.8 \mathrm{E}-05$ & $3.9 \mathrm{E}-06$ & $5.5 \mathrm{E}-07$ & $8.4 \mathrm{E}-08$ \\
\hline $\mathrm{D}$ & 10 & 1699 & $\overline{C C}$ & $1.0 \mathrm{E}+00$ & $9.7 \mathrm{E}-01$ & 7.6E-01 & $2.6 \mathrm{E}-01$ & $3.1 \mathrm{E}-02$ & $3.5 \mathrm{E}-03$ & $4.1 \mathrm{E}-04$ & 7.7E-05 & $1.0 \mathrm{E}-05$ & $1.9 \mathrm{E}-06$ & $3.5 \mathrm{E}-07$ \\
\hline$E$ & 10 & 1699 & $\mathrm{CC}$ & $1.0 \mathrm{E}+00$ & $9.9 \mathrm{E}-01$ & $8.9 \mathrm{E}-01$ & $4.8 \mathrm{E}-01$ & $7.7 \mathrm{E}-02$ & $9.3 \mathrm{E}-03$ & $8.7 \mathrm{E}-04$ & $1.5 \mathrm{E}-04$ & $2.2 \mathrm{E}-05$ & $4.0 \mathrm{E}-06$ & $9.4 \mathrm{E}-07$ \\
\hline $\bar{C}$ & 20 & 1699 & $\mathrm{CC}$ & $9.9 \mathrm{E}-01$ & $9.0 \mathrm{E}-01$ & $4.6 \mathrm{E}-01$ & $8.7 \mathrm{E}-02$ & $8.5 \mathrm{E}-03$ & $9.5 \mathrm{E}-04$ & $1.3 \mathrm{E}-04$ & $1.9 \mathrm{E}-05$ & $2.0 \mathrm{E}-06$ & $2.7 \mathrm{E}-07$ & $4.2 \mathrm{E}-08$ \\
\hline $\mathrm{D}$ & 20 & 1699 & $\mathrm{CC}$ & $9.9 \mathrm{E}-01$ & $9.4 \mathrm{E}-01$ & $6.1 \mathrm{E}-01$ & $1.5 \mathrm{E}-01$ & $1.6 \mathrm{E}-02$ & $1.8 \mathrm{E}-03$ & $2.1 \mathrm{E}-04$ & $3.9 \mathrm{E}-05$ & $5.1 \mathrm{E}-06$ & $9.3 \mathrm{E}-07$ & $1.8 \mathrm{E}-07$ \\
\hline $\bar{E}$ & 20 & 1699 & $\overline{\mathrm{CC}}$ & $1.0 \mathrm{E}+00$ & $9.7 \mathrm{E}-01$ & $8.1 \mathrm{E}-01$ & $3.2 \mathrm{E}-01$ & $4.0 \mathrm{E}-02$ & $4.7 \mathrm{E}-03$ & $4.3 \mathrm{E}-04$ & 7.7E-05 & $1.1 \mathrm{E}-05$ & $2.0 \mathrm{E}-06$ & $4.7 \mathrm{E}-07$ \\
\hline
\end{tabular}


Table A.5. AW Farm W-314; Fractional Concentrations at Ground Level (GC) and Plume Centerline (CC)

\begin{tabular}{|c|c|c|c|c|c|c|c|c|c|c|c|c|c|c|}
\hline \multirow{2}{*}{$\begin{array}{c}\text { Stability } \\
\text { Class }\end{array}$} & \multirow{2}{*}{$\begin{array}{c}\text { Wind } \\
\text { Speed } \\
\mathbf{m} / \mathbf{s}\end{array}$} & \multirow{2}{*}{$\begin{array}{c}\text { Venting } \\
\text { Rate } \\
\text { m3/hr }\end{array}$} & \multirow[b]{2}{*}{ Conc. } & \multicolumn{3}{|c|}{ Distance Downwind, m } & \multirow[b]{2}{*}{3} & \multirow[b]{2}{*}{10} & \multirow[b]{2}{*}{30} & \multirow[b]{2}{*}{100} & \multirow[b]{2}{*}{300} & \multirow[b]{2}{*}{1000} & \multirow[b]{2}{*}{3000} & \multirow[b]{2}{*}{10,000} \\
\hline & & & & 0.001 & 0.3 & 1 & & & & & & & & \\
\hline A & 1 & 1699 & GC & $0.0 \mathrm{E}+00$ & $0.0 \mathrm{E}+00$ & $0.0 \mathrm{E}+00$ & $1.6 \mathrm{E}-35$ & $2.8 \mathrm{E}-05$ & $2.8 \mathrm{E}-03$ & $6.3 \mathrm{E}-04$ & 7.6E-05 & 7.2E-06 & 8.7E-07 & $9.7 \mathrm{E}-08$ \\
\hline $\mathrm{B}$ & 1 & 1699 & GC & $0.0 \mathrm{E}+00$ & $0.0 \mathrm{E}+00$ & $0.0 \mathrm{E}+00$ & $0.0 \mathrm{E}+00$ & $2.0 \mathrm{E}-10$ & $1.2 \mathrm{E}-03$ & $1.2 \mathrm{E}-03$ & 1.7E-04 & $1.6 \mathrm{E}-05$ & $2.0 \mathrm{E}-06$ & $2.2 \mathrm{E}-07$ \\
\hline $\mathrm{C}$ & 1 & 1699 & GC & $0.0 \mathrm{E}+00$ & $0.0 \mathrm{E}+00$ & $0.0 \mathrm{E}+00$ & $0.0 \mathrm{E}+00$ & $7.3 \mathrm{E}-21$ & $1.4 \mathrm{E}-04$ & $1.9 \mathrm{E}-03$ & $3.7 \mathrm{E}-04$ & $3.9 \mathrm{E}-05$ & $5.5 \mathrm{E}-06$ & $8.4 \mathrm{E}-07$ \\
\hline $\mathrm{D}$ & 1 & 1699 & GC & $0.0 \mathrm{E}+00$ & $0.0 \mathrm{E}+00$ & $0.0 \mathrm{E}+00$ & $0.0 \mathrm{E}+00$ & 4.2E-36 & $3.6 \mathrm{E}-06$ & $2.1 \mathrm{E}-03$ & 7.2E-04 & $1.0 \mathrm{E}-04$ & $1.8 \mathrm{E}-05$ & $3.5 \mathrm{E}-06$ \\
\hline $\mathrm{E}$ & 1 & 1699 & $\mathrm{GC}$ & $0.0 \mathrm{E}+00$ & $0.0 \mathrm{E}+00$ & $0.0 \mathrm{E}+00$ & $0.0 \mathrm{E}+00$ & $0.0 \mathrm{E}+00$ & $2.8 \mathrm{E}-17$ & $3.4 \mathrm{E}-04$ & $1.2 \mathrm{E}-03$ & 2.1E-04 & $4.0 \mathrm{E}-05$ & $9.4 \mathrm{E}-06$ \\
\hline $\mathrm{F}$ & 1 & 1699 & $\mathrm{GC}$ & $0.0 \mathrm{E}+00$ & $0.0 \mathrm{E}+00$ & $0.0 \mathrm{E}+00$ & $0.0 \mathrm{E}+00$ & $0.0 \mathrm{E}+00$ & $0.0 \mathrm{E}+00$ & $1.8 \mathrm{E}-07$ & $9.4 \mathrm{E}-04$ & $5.0 \mathrm{E}-04$ & $1.1 \mathrm{E}-04$ & $2.6 \mathrm{E}-05$ \\
\hline A & 3.4 & 1699 & GC & $0.0 \mathrm{E}+00$ & $0.0 \mathrm{E}+00$ & $0.0 \mathrm{E}+00$ & $5.8 \mathrm{E}-36$ & $8.4 \mathrm{E}-06$ & 8.2E-04 & $1.8 \mathrm{E}-04$ & $2.2 \mathrm{E}-05$ & $2.1 \mathrm{E}-06$ & $2.5 \mathrm{E}-07$ & $2.8 \mathrm{E}-08$ \\
\hline B & 3.4 & 1699 & GC & $0.0 \mathrm{E}+00$ & $0.0 \mathrm{E}+00$ & $0.0 \mathrm{E}+00$ & $0.0 \mathrm{E}+00$ & $6.2 \mathrm{E}-11$ & $3.6 \mathrm{E}-04$ & $3.6 \mathrm{E}-04$ & $5.0 \mathrm{E}-05$ & $4.8 \mathrm{E}-06$ & $5.8 \mathrm{E}-07$ & $6.5 \mathrm{E}-08$ \\
\hline $\mathrm{C}$ & 3.4 & 1699 & GC & $0.0 \mathrm{E}+00$ & $0.0 \mathrm{E}+00$ & $0.0 \mathrm{E}+00$ & $0.0 \mathrm{E}+00$ & $2.4 \mathrm{E}-21$ & $4.1 \mathrm{E}-05$ & 5.7E-04 & 1.1E-04 & $1.1 \mathrm{E}-05$ & $1.6 \mathrm{E}-06$ & $2.5 \mathrm{E}-07$ \\
\hline $\mathrm{D}$ & 3.4 & 1699 & GC & $0.0 \mathrm{E}+00$ & $0.0 \mathrm{E}+00$ & $0.0 \mathrm{E}+00$ & $0.0 \mathrm{E}+00$ & $1.5 \mathrm{E}-36$ & $1.1 \mathrm{E}-06$ & $6.3 \mathrm{E}-04$ & 2.1E-04 & $3.0 \mathrm{E}-05$ & 5.4E-06 & $1.0 \mathrm{E}-06$ \\
\hline $\mathrm{E}$ & 3.4 & 1699 & GC & $0.0 \mathrm{E}+00$ & $0.0 \mathrm{E}+00$ & $0.0 \mathrm{E}+00$ & $0.0 \mathrm{E}+00$ & $0.0 \mathrm{E}+00$ & 8.6E-18 & $1.0 \mathrm{E}-04$ & $3.5 \mathrm{E}-04$ & $6.2 \mathrm{E}-05$ & $1.2 \mathrm{E}-05$ & $2.8 \mathrm{E}-06$ \\
\hline $\mathrm{F}$ & 3.4 & 1699 & GC & $0.0 \mathrm{E}+00$ & $0.0 \mathrm{E}+00$ & $0.0 \mathrm{E}+00$ & $0.0 \mathrm{E}+00$ & $0.0 \mathrm{E}+00$ & $0.0 \mathrm{E}+00$ & $5.5 \mathrm{E}-08$ & $2.8 \mathrm{E}-04$ & $1.5 \mathrm{E}-04$ & $3.1 \mathrm{E}-05$ & $7.6 \mathrm{E}-06$ \\
\hline G & 3.4 & 1699 & GC & $0.0 \mathrm{E}+00$ & $0.0 \mathrm{E}+00$ & $0.0 \mathrm{E}+00$ & $0.0 \mathrm{E}+00$ & $0.0 \mathrm{E}+00$ & $0.0 \mathrm{E}+00$ & $1.6 \mathrm{E}-20$ & $1.4 \mathrm{E}-05$ & 2.3E-04 & 7.6E-05 & $2.0 \mathrm{E}-05$ \\
\hline $\mathrm{C}$ & 10 & 1699 & GC & $0.0 \mathrm{E}+00$ & $0.0 \mathrm{E}+00$ & $0.0 \mathrm{E}+00$ & $0.0 \mathrm{E}+00$ & $8.4 \mathrm{E}-22$ & $1.4 \mathrm{E}-05$ & 1.9E-04 & $3.7 \mathrm{E}-05$ & $3.9 \mathrm{E}-06$ & $5.5 \mathrm{E}-07$ & $8.4 \mathrm{E}-08$ \\
\hline $\mathrm{D}$ & 10 & 1699 & GC & $0.0 \mathrm{E}+00$ & $0.0 \mathrm{E}+00$ & $0.0 \mathrm{E}+00$ & $0.0 \mathrm{E}+00$ & $5.4 \mathrm{E}-37$ & $3.8 \mathrm{E}-07$ & 2.2E-04 & 7.2E-05 & $1.0 \mathrm{E}-05$ & $1.8 \mathrm{E}-06$ & $3.5 \mathrm{E}-07$ \\
\hline$E$ & 10 & 1699 & GC & $0.0 \mathrm{E}+00$ & $0.0 \mathrm{E}+00$ & $0.0 \mathrm{E}+00$ & $0.0 \mathrm{E}+00$ & $0.0 \mathrm{E}+00$ & $3.0 \mathrm{E}-18$ & $3.4 \mathrm{E}-05$ & $1.2 \mathrm{E}-04$ & $2.1 \mathrm{E}-05$ & $4.0 \mathrm{E}-06$ & $9.4 \mathrm{E}-07$ \\
\hline $\mathrm{C}$ & 20 & 1699 & GC & $0.0 \mathrm{E}+00$ & $0.0 \mathrm{E}+00$ & $0.0 \mathrm{E}+00$ & $0.0 \mathrm{E}+00$ & $4.3 \mathrm{E}-22$ & $7.0 \mathrm{E}-06$ & $9.7 \mathrm{E}-05$ & $1.9 \mathrm{E}-05$ & $1.9 \mathrm{E}-06$ & $2.7 \mathrm{E}-07$ & $4.2 \mathrm{E}-08$ \\
\hline $\mathrm{D}$ & 20 & 1699 & GC & $0.0 \mathrm{E}+00$ & $0.0 \mathrm{E}+00$ & $0.0 \mathrm{E}+00$ & $0.0 \mathrm{E}+00$ & $2.7 \mathrm{E}-37$ & $1.9 \mathrm{E}-07$ & $1.1 \mathrm{E}-04$ & $3.6 \mathrm{E}-05$ & $5.1 \mathrm{E}-06$ & $9.2 \mathrm{E}-07$ & $1.8 \mathrm{E}-07$ \\
\hline $\mathrm{E}$ & 20 & 1699 & GC & $0.0 \mathrm{E}+00$ & $0.0 \mathrm{E}+00$ & $0.0 \mathrm{E}+00$ & $0.0 \mathrm{E}+00$ & $0.0 \mathrm{E}+00$ & $1.5 \mathrm{E}-18$ & $1.7 \mathrm{E}-05$ & $6.0 \mathrm{E}-05$ & $1.1 \mathrm{E}-05$ & $2.0 \mathrm{E}-06$ & $4.7 \mathrm{E}-07$ \\
\hline
\end{tabular}


Table A.5. (contd)

\begin{tabular}{|c|c|c|c|c|c|c|c|c|c|c|c|c|c|c|}
\hline \multirow{2}{*}{$\begin{array}{c}\text { Stability } \\
\text { Class }\end{array}$} & \multirow{2}{*}{$\begin{array}{c}\text { Wind } \\
\text { Speed } \\
\mathrm{m} / \mathrm{s}\end{array}$} & \multirow{2}{*}{$\begin{array}{c}\text { Venting } \\
\text { Rate } \\
\text { m3/hr }\end{array}$} & \multirow[b]{2}{*}{ Conc. } & \multicolumn{3}{|c|}{ Distance Downwind, $\mathbf{m}$} & \multirow[b]{2}{*}{3} & \multirow[b]{2}{*}{10} & \multirow[b]{2}{*}{30} & \multirow[b]{2}{*}{100} & \multirow[b]{2}{*}{300} & \multirow[b]{2}{*}{1000} & \multirow[b]{2}{*}{3000} & \multirow[b]{2}{*}{10,000} \\
\hline & & & & 0.001 & 0.3 & 1 & & & & & & & & \\
\hline A & 1 & 1699 & $\mathrm{CC}$ & $1.0 \mathrm{E}+00$ & $9.7 \mathrm{E}-01$ & $7.7 \mathrm{E}-01$ & $2.8 \mathrm{E}-01$ & 3.3E-02 & $3.9 \mathrm{E}-03$ & $5.8 \mathrm{E}-04$ & $7.5 \mathrm{E}-05$ & 7.1E-06 & $8.6 \mathrm{E}-07$ & 9.7E-08 \\
\hline B & 1 & 1699 & $\mathrm{CC}$ & $1.0 \mathrm{E}+00$ & $9.9 \mathrm{E}-01$ & $8.9 \mathrm{E}-01$ & 4.7E-01 & $7.3 \mathrm{E}-02$ & $8.6 \mathrm{E}-03$ & $1.1 \mathrm{E}-03$ & $1.7 \mathrm{E}-04$ & $1.6 \mathrm{E}-05$ & $2.0 \mathrm{E}-06$ & $2.2 \mathrm{E}-07$ \\
\hline $\mathrm{C}$ & 1 & 1699 & $\mathrm{CC}$ & $1.0 \mathrm{E}+00$ & $9.9 \mathrm{E}-01$ & $9.4 \mathrm{E}-01$ & $6.5 \mathrm{E}-01$ & $1.5 \mathrm{E}-01$ & $1.9 \mathrm{E}-02$ & $1.9 \mathrm{E}-03$ & $3.5 \mathrm{E}-04$ & $3.9 \mathrm{E}-05$ & $5.5 \mathrm{E}-06$ & 8.4E-07 \\
\hline $\mathrm{D}$ & 1 & 1699 & $\mathrm{CC}$ & $1.0 \mathrm{E}+00$ & $1.0 \mathrm{E}+00$ & $9.7 \mathrm{E}-01$ & $7.8 \mathrm{E}-01$ & $2.4 \mathrm{E}-01$ & $3.4 \mathrm{E}-02$ & $3.4 \mathrm{E}-03$ & $6.5 \mathrm{E}-04$ & $9.9 \mathrm{E}-05$ & $1.8 \mathrm{E}-05$ & $3.5 \mathrm{E}-06$ \\
\hline $\mathrm{E}$ & 1 & 1699 & $\mathrm{CC}$ & $1.0 \mathrm{E}+00$ & $1.0 \mathrm{E}+00$ & $9.9 \mathrm{E}-01$ & $9.0 \mathrm{E}-01$ & $4.6 \mathrm{E}-01$ & $8.6 \mathrm{E}-02$ & $8.6 \mathrm{E}-03$ & $1.1 \mathrm{E}-03$ & $2.0 \mathrm{E}-04$ & $3.9 \mathrm{E}-05$ & $9.3 \mathrm{E}-06$ \\
\hline $\mathrm{F}$ & 1 & 1699 & $\mathrm{CC}$ & $1.0 \mathrm{E}+00$ & $1.0 \mathrm{E}+00$ & $1.0 \mathrm{E}+00$ & $9.6 \mathrm{E}-01$ & $7.0 \mathrm{E}-01$ & $2.1 \mathrm{E}-01$ & $2.4 \mathrm{E}-02$ & $2.9 \mathrm{E}-03$ & $4.4 \mathrm{E}-04$ & $1.0 \mathrm{E}-04$ & $2.5 \mathrm{E}-05$ \\
\hline A & 3.4 & 1699 & $\mathrm{CC}$ & $9.9 \mathrm{E}-01$ & $9.2 \mathrm{E}-01$ & $5.0 \mathrm{E}-01$ & $1.0 \mathrm{E}-01$ & $9.9 \mathrm{E}-03$ & $1.1 \mathrm{E}-03$ & $1.7 \mathrm{E}-04$ & $2.2 \mathrm{E}-05$ & $2.1 \mathrm{E}-06$ & $2.5 \mathrm{E}-07$ & $2.8 \mathrm{E}-08$ \\
\hline B & 3.4 & 1699 & $\mathrm{CC}$ & $1.0 \mathrm{E}+00$ & $9.6 \mathrm{E}-01$ & $7.0 \mathrm{E}-01$ & $2.0 \mathrm{E}-01$ & $2.3 \mathrm{E}-02$ & $2.6 \mathrm{E}-03$ & $3.2 \mathrm{E}-04$ & $4.9 \mathrm{E}-05$ & $4.8 \mathrm{E}-06$ & $5.8 \mathrm{E}-07$ & $6.5 \mathrm{E}-08$ \\
\hline $\mathrm{C}$ & 3.4 & 1699 & $\mathrm{CC}$ & $1.0 \mathrm{E}+00$ & $9.8 \mathrm{E}-01$ & $8.3 \mathrm{E}-01$ & $3.6 \mathrm{E}-01$ & $4.8 \mathrm{E}-02$ & $5.6 \mathrm{E}-03$ & $5.6 \mathrm{E}-04$ & $1.0 \mathrm{E}-04$ & $1.1 \mathrm{E}-05$ & $1.6 \mathrm{E}-06$ & $2.5 \mathrm{E}-07$ \\
\hline $\mathrm{D}$ & 3.4 & 1699 & $\mathrm{CC}$ & $1.0 \mathrm{E}+00$ & $9.9 \mathrm{E}-01$ & $9.0 \mathrm{E}-01$ & $5.1 \mathrm{E}-01$ & $8.5 \mathrm{E}-02$ & $1.0 \mathrm{E}-02$ & $1.0 \mathrm{E}-03$ & $1.9 \mathrm{E}-04$ & $2.9 \mathrm{E}-05$ & $5.4 \mathrm{E}-06$ & $1.0 \mathrm{E}-06$ \\
\hline $\mathrm{E}$ & 3.4 & 1699 & $\mathrm{CC}$ & $1.0 \mathrm{E}+00$ & $1.0 \mathrm{E}+00$ & $9.6 \mathrm{E}-01$ & 7.3E-01 & $2.0 \mathrm{E}-01$ & $2.7 \mathrm{E}-02$ & $2.5 \mathrm{E}-03$ & $3.4 \mathrm{E}-04$ & $5.9 \mathrm{E}-05$ & $1.1 \mathrm{E}-05$ & 2.7E-06 \\
\hline $\mathrm{F}$ & 3.4 & 1699 & $\mathrm{CC}$ & $1.0 \mathrm{E}+00$ & $1.0 \mathrm{E}+00$ & $9.9 \mathrm{E}-01$ & $8.8 \mathrm{E}-01$ & $4.1 \mathrm{E}-01$ & 7.2E-02 & $7.1 \mathrm{E}-03$ & $8.5 \mathrm{E}-04$ & $1.3 \mathrm{E}-04$ & $3.0 \mathrm{E}-05$ & $7.5 \mathrm{E}-06$ \\
\hline$G$ & 3.4 & 1699 & $\mathrm{CC}$ & $1.0 \mathrm{E}+00$ & $1.0 \mathrm{E}+00$ & $9.9 \mathrm{E}-01$ & $9.6 \mathrm{E}-01$ & $6.6 \mathrm{E}-01$ & $1.8 \mathrm{E}-01$ & $2.0 \mathrm{E}-02$ & $2.4 \mathrm{E}-03$ & 2.7E-04 & $6.7 \mathrm{E}-05$ & $1.9 \mathrm{E}-05$ \\
\hline $\mathrm{C}$ & 10 & 1699 & $\mathrm{CC}$ & $9.9 \mathrm{E}-01$ & $9.5 \mathrm{E}-01$ & $6.3 \mathrm{E}-01$ & $1.6 \mathrm{E}-01$ & $1.7 \mathrm{E}-02$ & $1.9 \mathrm{E}-03$ & $1.9 \mathrm{E}-04$ & $3.5 \mathrm{E}-05$ & $3.9 \mathrm{E}-06$ & $5.5 \mathrm{E}-07$ & 8.4E-08 \\
\hline $\mathrm{D}$ & 10 & 1699 & $\mathrm{CC}$ & $1.0 \mathrm{E}+00$ & $9.7 \mathrm{E}-01$ & 7.6E-01 & $2.6 \mathrm{E}-01$ & $3.1 \mathrm{E}-02$ & $3.5 \mathrm{E}-03$ & 3.4E-04 & $6.5 \mathrm{E}-05$ & $9.9 \mathrm{E}-06$ & $1.8 \mathrm{E}-06$ & $3.5 \mathrm{E}-07$ \\
\hline $\mathrm{E}$ & 10 & 1699 & $\mathrm{CC}$ & $1.0 \mathrm{E}+00$ & $9.9 \mathrm{E}-01$ & $8.9 \mathrm{E}-01$ & $4.8 \mathrm{E}-01$ & 7.7E-02 & $9.3 \mathrm{E}-03$ & $8.6 \mathrm{E}-04$ & $1.1 \mathrm{E}-04$ & $2.0 \mathrm{E}-05$ & $3.9 \mathrm{E}-06$ & $9.3 \mathrm{E}-07$ \\
\hline $\mathrm{C}$ & 20 & 1699 & $\mathrm{CC}$ & $9.9 \mathrm{E}-01$ & $9.0 \mathrm{E}-01$ & 4.6E-01 & $8.7 \mathrm{E}-02$ & $8.5 \mathrm{E}-03$ & $9.5 \mathrm{E}-04$ & $9.5 \mathrm{E}-05$ & $1.7 \mathrm{E}-05$ & $1.9 \mathrm{E}-06$ & $2.7 \mathrm{E}-07$ & 4.2E- 08 \\
\hline $\mathrm{D}$ & 20 & 1699 & $\mathrm{CC}$ & $9.9 \mathrm{E}-01$ & $9.5 \mathrm{E}-01$ & $6.1 \mathrm{E}-01$ & $1.5 \mathrm{E}-01$ & $1.6 \mathrm{E}-02$ & $1.8 \mathrm{E}-03$ & $1.7 \mathrm{E}-04$ & $3.2 \mathrm{E}-05$ & $4.9 \mathrm{E}-06$ & $9.2 \mathrm{E}-07$ & $1.8 \mathrm{E}-07$ \\
\hline $\mathrm{E}$ & 20 & 1699 & $\mathrm{CC}$ & $1.0 \mathrm{E}+00$ & $9.8 \mathrm{E}-01$ & $8.1 \mathrm{E}-01$ & 3.2E-01 & $4.0 \mathrm{E}-02$ & $4.7 \mathrm{E}-03$ & $4.3 \mathrm{E}-04$ & $5.7 \mathrm{E}-05$ & $1.0 \mathrm{E}-05$ & $1.9 \mathrm{E}-06$ & 4.7E-07 \\
\hline
\end{tabular}


Table A.5. (contd)

\begin{tabular}{|c|c|c|c|c|c|c|c|c|c|c|c|c|c|c|}
\hline \multirow{2}{*}{$\begin{array}{c}\text { Stability } \\
\text { Class }\end{array}$} & \multirow{2}{*}{$\begin{array}{c}\text { Wind } \\
\text { Speed } \\
\mathrm{m} / \mathrm{s}\end{array}$} & \multirow{2}{*}{$\begin{array}{c}\text { Venting } \\
\text { Rate } \\
\text { m3/hr }\end{array}$} & \multirow[b]{2}{*}{ Conc. } & \multicolumn{3}{|c|}{ Distance Downwind, $\mathbf{m}$} & \multirow[b]{2}{*}{3} & \multirow[b]{2}{*}{10} & \multirow[b]{2}{*}{30} & \multirow[b]{2}{*}{100} & \multirow[b]{2}{*}{300} & \multirow[b]{2}{*}{1000} & \multirow[b]{2}{*}{3000} & \multirow[b]{2}{*}{10,000} \\
\hline & & & & 0.001 & 0.3 & 1 & & & & & & & & \\
\hline A & 1 & 3398 & GC & $0.0 \mathrm{E}+00$ & $0.0 \mathrm{E}+00$ & $0.0 \mathrm{E}+00$ & $2.5 \mathrm{E}-35$ & $5.4 \mathrm{E}-05$ & $5.6 \mathrm{E}-03$ & $1.3 \mathrm{E}-03$ & $1.5 \mathrm{E}-04$ & $1.4 \mathrm{E}-05$ & $1.7 \mathrm{E}-06$ & $1.9 \mathrm{E}-07$ \\
\hline B & 1 & 3398 & $\mathrm{GC}$ & $0.0 \mathrm{E}+00$ & $0.0 \mathrm{E}+00$ & $0.0 \mathrm{E}+00$ & $0.0 \mathrm{E}+00$ & $3.7 \mathrm{E}-10$ & $2.4 \mathrm{E}-03$ & $2.4 \mathrm{E}-03$ & $3.4 \mathrm{E}-04$ & $3.3 \mathrm{E}-05$ & $4.0 \mathrm{E}-06$ & 4.4E-07 \\
\hline $\mathrm{C}$ & 1 & 3398 & $\overline{\mathrm{GC}}$ & $0.0 \mathrm{E}+00$ & $0.0 \mathrm{E}+00$ & $0.0 \mathrm{E}+00$ & $0.0 \mathrm{E}+00$ & $1.3 \mathrm{E}-20$ & $2.7 \mathrm{E}-04$ & $3.9 \mathrm{E}-03$ & 7.4E-04 & $7.8 \mathrm{E}-05$ & $1.1 \mathrm{E}-05$ & $1.7 \mathrm{E}-06$ \\
\hline $\mathrm{D}$ & 1 & 3398 & $\mathrm{GC}$ & $0.0 \mathrm{E}+00$ & $0.0 \mathrm{E}+00$ & $0.0 \mathrm{E}+00$ & $0.0 \mathrm{E}+00$ & $6.8 \mathrm{E}-36$ & $7.1 \mathrm{E}-06$ & $4.3 \mathrm{E}-03$ & $1.4 \mathrm{E}-03$ & $2.0 \mathrm{E}-04$ & $3.7 \mathrm{E}-05$ & $7.1 \mathrm{E}-06$ \\
\hline $\mathrm{E}$ & 1 & 3398 & $\mathrm{GC}$ & $0.0 \mathrm{E}+00$ & $0.0 \mathrm{E}+00$ & $0.0 \mathrm{E}+00$ & $0.0 \mathrm{E}+00$ & $0.0 \mathrm{E}+00$ & $5.1 \mathrm{E}-17$ & $6.8 \mathrm{E}-04$ & $2.4 \mathrm{E}-03$ & $4.2 \mathrm{E}-04$ & $7.9 \mathrm{E}-05$ & $1.9 \mathrm{E}-05$ \\
\hline $\mathrm{F}$ & 1 & 3398 & GC & $0.0 \mathrm{E}+00$ & $0.0 \mathrm{E}+00$ & $0.0 \mathrm{E}+00$ & $0.0 \mathrm{E}+00$ & $0.0 \mathrm{E}+00$ & $0.0 \mathrm{E}+00$ & $3.6 \mathrm{E}-07$ & $1.9 \mathrm{E}-03$ & $1.0 \mathrm{E}-03$ & 2.1E-04 & $5.2 \mathrm{E}-05$ \\
\hline A & 3.4 & 3398 & GC & $0.0 \mathrm{E}+00$ & $0.0 \mathrm{E}+00$ & $0.0 \mathrm{E}+00$ & $1.0 \mathrm{E}-35$ & $1.7 \mathrm{E}-05$ & $1.6 \mathrm{E}-03$ & 3.7E-04 & $4.5 \mathrm{E}-05$ & $4.2 \mathrm{E}-06$ & $5.1 \mathrm{E}-07$ & 5.7E- 08 \\
\hline B & 3.4 & 3398 & $\mathrm{GC}$ & $0.0 \mathrm{E}+00$ & $0.0 \mathrm{E}+00$ & $0.0 \mathrm{E}+00$ & $0.0 \mathrm{E}+00$ & $1.2 \mathrm{E}-10$ & 7.2E-04 & 7.2E-04 & $1.0 \mathrm{E}-04$ & $9.6 \mathrm{E}-06$ & $1.2 \mathrm{E}-06$ & $1.3 \mathrm{E}-07$ \\
\hline $\mathrm{C}$ & 3.4 & 3398 & GC & $0.0 \mathrm{E}+00$ & $0.0 \mathrm{E}+00$ & $0.0 \mathrm{E}+00$ & $0.0 \mathrm{E}+00$ & $4.6 \mathrm{E}-21$ & $8.2 \mathrm{E}-05$ & $1.1 \mathrm{E}-03$ & $2.2 \mathrm{E}-04$ & $2.3 \mathrm{E}-05$ & $3.2 \mathrm{E}-06$ & $4.9 \mathrm{E}-07$ \\
\hline $\mathrm{D}$ & 3.4 & 3398 & GC & $0.0 \mathrm{E}+00$ & $0.0 \mathrm{E}+00$ & $0.0 \mathrm{E}+00$ & $0.0 \mathrm{E}+00$ & $2.8 \mathrm{E}-36$ & $2.2 \mathrm{E}-06$ & $1.3 \mathrm{E}-03$ & $4.2 \mathrm{E}-04$ & $6.0 \mathrm{E}-05$ & $1.1 \mathrm{E}-05$ & $2.1 \mathrm{E}-06$ \\
\hline $\mathrm{E}$ & 3.4 & 3398 & GC & $0.0 \mathrm{E}+00$ & $0.0 \mathrm{E}+00$ & $0.0 \mathrm{E}+00$ & $0.0 \mathrm{E}+00$ & $0.0 \mathrm{E}+00$ & $1.7 \mathrm{E}-17$ & $2.0 \mathrm{E}-04$ & 7.1E-04 & $1.2 \mathrm{E}-04$ & $2.3 \mathrm{E}-05$ & $5.5 \mathrm{E}-06$ \\
\hline $\mathrm{F}$ & 3.4 & 3398 & GC & $0.0 \mathrm{E}+00$ & $0.0 \mathrm{E}+00$ & $0.0 \mathrm{E}+00$ & $0.0 \mathrm{E}+00$ & $0.0 \mathrm{E}+00$ & $0.0 \mathrm{E}+00$ & $1.1 \mathrm{E}-07$ & $5.5 \mathrm{E}-04$ & $3.0 \mathrm{E}-04$ & $6.3 \mathrm{E}-05$ & $1.5 \mathrm{E}-05$ \\
\hline$G$ & 3.4 & 3398 & GC & $0.0 \mathrm{E}+00$ & $0.0 \mathrm{E}+00$ & $0.0 \mathrm{E}+00$ & $0.0 \mathrm{E}+00$ & $0.0 \mathrm{E}+00$ & $0.0 \mathrm{E}+00$ & $3.0 \mathrm{E}-20$ & $2.8 \mathrm{E}-05$ & $4.5 \mathrm{E}-04$ & $1.5 \mathrm{E}-04$ & $4.0 \mathrm{E}-05$ \\
\hline $\mathrm{C}$ & 10 & 3398 & GC & $0.0 \mathrm{E}+00$ & $0.0 \mathrm{E}+00$ & $0.0 \mathrm{E}+00$ & $0.0 \mathrm{E}+00$ & $1.7 \mathrm{E}-21$ & $2.8 \mathrm{E}-05$ & $3.9 \mathrm{E}-04$ & 7.4E-05 & $7.8 \mathrm{E}-06$ & $1.1 \mathrm{E}-06$ & $1.7 \mathrm{E}-07$ \\
\hline $\mathrm{D}$ & 10 & 3398 & $\overline{G C}$ & $0.0 \mathrm{E}+00$ & $0.0 \mathrm{E}+00$ & $0.0 \mathrm{E}+00$ & $0.0 \mathrm{E}+00$ & $1.0 \mathrm{E}-36$ & $7.5 \mathrm{E}-07$ & $4.3 \mathrm{E}-04$ & $1.4 \mathrm{E}-04$ & $2.0 \mathrm{E}-05$ & $3.7 \mathrm{E}-06$ & 7.1E-07 \\
\hline $\mathrm{E}$ & 10 & 3398 & GC & $0.0 \mathrm{E}+00$ & $0.0 \mathrm{E}+00$ & $0.0 \mathrm{E}+00$ & $0.0 \mathrm{E}+00$ & $0.0 \mathrm{E}+00$ & $5.9 \mathrm{E}-18$ & $6.9 \mathrm{E}-05$ & $2.4 \mathrm{E}-04$ & $4.2 \mathrm{E}-05$ & $7.9 \mathrm{E}-06$ & $1.9 \mathrm{E}-06$ \\
\hline $\mathrm{C}$ & 20 & 3398 & $\mathrm{GC}$ & $0.0 \mathrm{E}+00$ & $0.0 \mathrm{E}+00$ & $0.0 \mathrm{E}+00$ & $0.0 \mathrm{E}+00$ & $8.4 \mathrm{E}-22$ & $1.4 \mathrm{E}-05$ & $1.9 \mathrm{E}-04$ & $3.7 \mathrm{E}-05$ & $3.9 \mathrm{E}-06$ & $5.5 \mathrm{E}-07$ & $8.4 \mathrm{E}-08$ \\
\hline $\mathrm{D}$ & 20 & 3398 & GC & $0.0 \mathrm{E}+00$ & $0.0 \mathrm{E}+00$ & $0.0 \mathrm{E}+00$ & $0.0 \mathrm{E}+00$ & $5.4 \mathrm{E}-37$ & $3.8 \mathrm{E}-07$ & $2.2 \mathrm{E}-04$ & 7.2E-05 & $1.0 \mathrm{E}-05$ & $1.8 \mathrm{E}-06$ & $3.5 \mathrm{E}-07$ \\
\hline $\mathrm{E}$ & 20 & 3398 & GC & $0.0 \mathrm{E}+00$ & $0.0 \mathrm{E}+00$ & $0.0 \mathrm{E}+00$ & $0.0 \mathrm{E}+00$ & $0.0 \mathrm{E}+00$ & $3.0 \mathrm{E}-18$ & $3.4 \mathrm{E}-05$ & $1.2 \mathrm{E}-04$ & $2.1 \mathrm{E}-05$ & $4.0 \mathrm{E}-06$ & 9.4E-07 \\
\hline
\end{tabular}


Table A.5. (contd)

\begin{tabular}{|c|c|c|c|c|c|c|c|c|c|c|c|c|c|c|}
\hline \multirow{2}{*}{$\begin{array}{c}\text { Stability } \\
\text { Class }\end{array}$} & \multirow{2}{*}{$\begin{array}{c}\text { Wind } \\
\text { Speed } \\
\mathrm{m} / \mathrm{s}\end{array}$} & \multirow{2}{*}{$\begin{array}{c}\text { Venting } \\
\text { Rate } \\
\text { m3/hr }\end{array}$} & \multirow[b]{2}{*}{ Conc. } & \multicolumn{3}{|c|}{ Distance Downwind, $\mathbf{m}$} & \multirow[b]{2}{*}{3} & \multirow[b]{2}{*}{10} & \multirow[b]{2}{*}{30} & \multirow[b]{2}{*}{100} & \multirow[b]{2}{*}{300} & \multirow[b]{2}{*}{1000} & \multirow[b]{2}{*}{3000} & \multirow[b]{2}{*}{10,000} \\
\hline & & & & 0.001 & 0.3 & 1 & & & & & & & & \\
\hline A & 1 & 3398 & $\mathrm{CC}$ & $1.0 \mathrm{E}+00$ & $9.9 \mathrm{E}-01$ & $8.7 \mathrm{E}-01$ & 4.3E-01 & $6.4 \mathrm{E}-02$ & $7.7 \mathrm{E}-03$ & $1.2 \mathrm{E}-03$ & $1.5 \mathrm{E}-04$ & $1.4 \mathrm{E}-05$ & $1.7 \mathrm{E}-06$ & $1.9 \mathrm{E}-07$ \\
\hline $\mathrm{B}$ & 1 & 3398 & $\mathrm{CC}$ & $1.0 \mathrm{E}+00$ & $9.9 \mathrm{E}-01$ & $9.4 \mathrm{E}-01$ & $6.3 \mathrm{E}-01$ & $1.4 \mathrm{E}-01$ & $1.7 \mathrm{E}-02$ & $2.1 \mathrm{E}-03$ & $3.3 \mathrm{E}-04$ & $3.3 \mathrm{E}-05$ & $4.0 \mathrm{E}-06$ & 4.4E-07 \\
\hline $\mathrm{C}$ & 1 & 3398 & $\mathrm{CC}$ & $1.0 \mathrm{E}+00$ & $1.0 \mathrm{E}+00$ & $9.7 \mathrm{E}-01$ & 7.9E-01 & $2.5 \mathrm{E}-01$ & $3.7 \mathrm{E}-02$ & $3.8 \mathrm{E}-03$ & 7.0E-04 & 7.7E-05 & $1.1 \mathrm{E}-05$ & $1.7 \mathrm{E}-06$ \\
\hline $\mathrm{D}$ & 1 & 3398 & $\mathrm{CC}$ & $1.0 \mathrm{E}+00$ & $1.0 \mathrm{E}+00$ & $9.8 \mathrm{E}-01$ & $8.7 \mathrm{E}-01$ & $3.9 \mathrm{E}-01$ & $6.6 \mathrm{E}-02$ & $6.8 \mathrm{E}-03$ & $1.3 \mathrm{E}-03$ & $2.0 \mathrm{E}-04$ & $3.7 \mathrm{E}-05$ & $7.1 \mathrm{E}-06$ \\
\hline $\mathrm{E}$ & 1 & 3398 & $\mathrm{CC}$ & $1.0 \mathrm{E}+00$ & $1.0 \mathrm{E}+00$ & $9.9 \mathrm{E}-01$ & $9.5 \mathrm{E}-01$ & $6.3 \mathrm{E}-01$ & $1.6 \mathrm{E}-01$ & $1.7 \mathrm{E}-02$ & $2.3 \mathrm{E}-03$ & $4.0 \mathrm{E}-04$ & $7.8 \mathrm{E}-05$ & $1.9 \mathrm{E}-05$ \\
\hline $\mathrm{F}$ & 1 & 3398 & $\mathrm{CC}$ & $1.0 \mathrm{E}+00$ & $1.0 \mathrm{E}+00$ & $1.0 \mathrm{E}+00$ & $9.8 \mathrm{E}-01$ & $8.2 \mathrm{E}-01$ & $3.5 \mathrm{E}-01$ & $4.6 \mathrm{E}-02$ & $5.7 \mathrm{E}-03$ & $8.8 \mathrm{E}-04$ & $2.0 \mathrm{E}-04$ & $5.1 \mathrm{E}-05$ \\
\hline A & 3.4 & 3398 & $\mathrm{CC}$ & $1.0 \mathrm{E}+00$ & $9.6 \mathrm{E}-01$ & $6.7 \mathrm{E}-01$ & $1.8 \mathrm{E}-01$ & $2.0 \mathrm{E}-02$ & $2.3 \mathrm{E}-03$ & 3.4E-04 & $4.4 \mathrm{E}-05$ & $4.2 \mathrm{E}-06$ & $5.1 \mathrm{E}-07$ & 5.7E- 08 \\
\hline B & 3.4 & 3398 & $\mathrm{CC}$ & $1.0 \mathrm{E}+00$ & $9.8 \mathrm{E}-01$ & $8.2 \mathrm{E}-01$ & 3.4E-01 & $4.4 \mathrm{E}-02$ & $5.1 \mathrm{E}-03$ & $6.3 \mathrm{E}-04$ & $9.8 \mathrm{E}-05$ & $9.6 \mathrm{E}-06$ & $1.2 \mathrm{E}-06$ & $1.3 \mathrm{E}-07$ \\
\hline $\mathrm{C}$ & 3.4 & 3398 & $\mathrm{CC}$ & $1.0 \mathrm{E}+00$ & $9.9 \mathrm{E}-01$ & $9.1 \mathrm{E}-01$ & $5.3 \mathrm{E}-01$ & $9.1 \mathrm{E}-02$ & $1.1 \mathrm{E}-02$ & $1.1 \mathrm{E}-03$ & $2.1 \mathrm{E}-04$ & $2.3 \mathrm{E}-05$ & $3.2 \mathrm{E}-06$ & $4.9 \mathrm{E}-07$ \\
\hline $\mathrm{D}$ & 3.4 & 3398 & $\mathrm{CC}$ & $1.0 \mathrm{E}+00$ & $1.0 \mathrm{E}+00$ & $9.5 \mathrm{E}-01$ & $6.7 \mathrm{E}-01$ & $1.6 \mathrm{E}-01$ & $2.1 \mathrm{E}-02$ & $2.0 \mathrm{E}-03$ & $3.8 \mathrm{E}-04$ & $5.8 \mathrm{E}-05$ & $1.1 \mathrm{E}-05$ & $2.1 \mathrm{E}-06$ \\
\hline $\mathrm{E}$ & 3.4 & 3398 & $\mathrm{CC}$ & $1.0 \mathrm{E}+00$ & $1.0 \mathrm{E}+00$ & $9.8 \mathrm{E}-01$ & $8.5 \mathrm{E}-01$ & $3.3 \mathrm{E}-01$ & $5.2 \mathrm{E}-02$ & $5.1 \mathrm{E}-03$ & $6.7 \mathrm{E}-04$ & $1.2 \mathrm{E}-04$ & $2.3 \mathrm{E}-05$ & $5.5 \mathrm{E}-06$ \\
\hline $\mathrm{F}$ & 3.4 & 3398 & $\mathrm{CC}$ & $1.0 \mathrm{E}+00$ & $1.0 \mathrm{E}+00$ & $9.9 \mathrm{E}-01$ & 9.4E-01 & $5.8 \mathrm{E}-01$ & $1.3 \mathrm{E}-01$ & $1.4 \mathrm{E}-02$ & $1.7 \mathrm{E}-03$ & $2.6 \mathrm{E}-04$ & $6.0 \mathrm{E}-05$ & $1.5 \mathrm{E}-05$ \\
\hline$G$ & 3.4 & 3398 & $\mathrm{CC}$ & $1.0 \mathrm{E}+00$ & $1.0 \mathrm{E}+00$ & $1.0 \mathrm{E}+00$ & $9.8 \mathrm{E}-01$ & 7.9E-01 & $3.0 \mathrm{E}-01$ & $3.8 \mathrm{E}-02$ & $4.7 \mathrm{E}-03$ & 5.4E-04 & $1.3 \mathrm{E}-04$ & $3.8 \mathrm{E}-05$ \\
\hline $\mathrm{C}$ & 10 & 3398 & $\mathrm{CC}$ & $1.0 \mathrm{E}+00$ & $9.7 \mathrm{E}-01$ & 7.7E-01 & $2.8 \mathrm{E}-01$ & $3.3 \mathrm{E}-02$ & $3.8 \mathrm{E}-03$ & $3.8 \mathrm{E}-04$ & $7.0 \mathrm{E}-05$ & 7.7E-06 & $1.1 \mathrm{E}-06$ & $1.7 \mathrm{E}-07$ \\
\hline $\mathrm{D}$ & 10 & 3398 & $\overline{C C}$ & $1.0 \mathrm{E}+00$ & $9.9 \mathrm{E}-01$ & $8.6 \mathrm{E}-01$ & $4.1 \mathrm{E}-01$ & $5.9 \mathrm{E}-02$ & 7.1E-03 & $6.8 \mathrm{E}-04$ & $1.3 \mathrm{E}-04$ & $2.0 \mathrm{E}-05$ & $3.7 \mathrm{E}-06$ & 7.1E-07 \\
\hline $\mathrm{E}$ & 10 & 3398 & $\mathrm{CC}$ & $1.0 \mathrm{E}+00$ & $9.9 \mathrm{E}-01$ & $9.4 \mathrm{E}-01$ & $6.5 \mathrm{E}-01$ & $1.4 \mathrm{E}-01$ & $1.8 \mathrm{E}-02$ & $1.7 \mathrm{E}-03$ & $2.3 \mathrm{E}-04$ & $4.0 \mathrm{E}-05$ & $7.8 \mathrm{E}-06$ & $1.9 \mathrm{E}-06$ \\
\hline $\mathrm{C}$ & 20 & 3398 & $\mathrm{CC}$ & $9.9 \mathrm{E}-01$ & $9.5 \mathrm{E}-01$ & $6.3 \mathrm{E}-01$ & $1.6 \mathrm{E}-01$ & $1.7 \mathrm{E}-02$ & $1.9 \mathrm{E}-03$ & $1.9 \mathrm{E}-04$ & $3.5 \mathrm{E}-05$ & $3.9 \mathrm{E}-06$ & $5.5 \mathrm{E}-07$ & $8.4 \mathrm{E}-08$ \\
\hline $\mathrm{D}$ & 20 & 3398 & $\mathrm{CC}$ & $1.0 \mathrm{E}+00$ & $9.7 \mathrm{E}-01$ & 7.6E-01 & $2.6 \mathrm{E}-01$ & $3.1 \mathrm{E}-02$ & $3.5 \mathrm{E}-03$ & $3.4 \mathrm{E}-04$ & $6.5 \mathrm{E}-05$ & $9.9 \mathrm{E}-06$ & $1.8 \mathrm{E}-06$ & $3.5 \mathrm{E}-07$ \\
\hline $\mathrm{E}$ & 20 & 3398 & $\mathrm{CC}$ & $1.0 \mathrm{E}+00$ & $9.9 \mathrm{E}-01$ & $8.9 \mathrm{E}-01$ & $4.8 \mathrm{E}-01$ & 7.7E-02 & $9.3 \mathrm{E}-03$ & 8.6E-04 & $1.1 \mathrm{E}-04$ & $2.0 \mathrm{E}-05$ & 3.9E-06 & $9.3 \mathrm{E}-07$ \\
\hline
\end{tabular}


Table A.6. AY/AZ Existing Vent; Fractional Concentrations at Ground Level (GC) and Plume Centerline (CC)

\begin{tabular}{|c|c|c|c|c|c|c|c|c|c|c|c|c|c|c|}
\hline \multirow{2}{*}{$\begin{array}{c}\text { Stability } \\
\text { Class }\end{array}$} & \multirow{2}{*}{$\begin{array}{c}\text { Wind } \\
\text { Speed } \\
\text { m/s }\end{array}$} & \multirow{2}{*}{$\begin{array}{c}\text { Venting } \\
\text { Rate } \\
\text { m3/hr }\end{array}$} & \multirow[b]{2}{*}{ Conc. } & \multicolumn{3}{|c|}{ Distance Downwind, m } & \multirow[b]{2}{*}{3} & \multirow[b]{2}{*}{10} & \multirow[b]{2}{*}{30} & \multirow[b]{2}{*}{100} & \multirow[b]{2}{*}{300} & \multirow[b]{2}{*}{1000} & \multirow[b]{2}{*}{3000} & \multirow[b]{2}{*}{10,000} \\
\hline & & & & 0.001 & 0.3 & 1 & & & & & & & & \\
\hline A & 1 & 1699 & GC & $0.0 \mathrm{E}+00$ & $0.0 \mathrm{E}+00$ & $0.0 \mathrm{E}+00$ & $0.0 \mathrm{E}+00$ & $1.1 \mathrm{E}-15$ & $1.7 \mathrm{E}-04$ & $4.8 \mathrm{E}-04$ & 7.4E-05 & 7.1E-06 & 8.6E-07 & 9.7E-08 \\
\hline $\mathrm{B}$ & 1 & 1699 & GC & $0.0 \mathrm{E}+00$ & $0.0 \mathrm{E}+00$ & $0.0 \mathrm{E}+00$ & $0.0 \mathrm{E}+00$ & $2.4 \mathrm{E}-39$ & $6.4 \mathrm{E}-07$ & $5.9 \mathrm{E}-04$ & $1.6 \mathrm{E}-04$ & $1.6 \mathrm{E}-05$ & $2.0 \mathrm{E}-06$ & 2.2E-07 \\
\hline $\mathrm{C}$ & 1 & 1699 & GC & $0.0 \mathrm{E}+00$ & $0.0 \mathrm{E}+00$ & $0.0 \mathrm{E}+00$ & $0.0 \mathrm{E}+00$ & $0.0 \mathrm{E}+00$ & 7.1E-12 & $3.8 \mathrm{E}-04$ & $3.1 \mathrm{E}-04$ & $3.8 \mathrm{E}-05$ & $5.4 \mathrm{E}-06$ & $8.4 \mathrm{E}-07$ \\
\hline $\mathrm{D}$ & 1 & 1699 & $\mathrm{GC}$ & $0.0 \mathrm{E}+00$ & $0.0 \mathrm{E}+00$ & $0.0 \mathrm{E}+00$ & $0.0 \mathrm{E}+00$ & $0.0 \mathrm{E}+00$ & $1.4 \mathrm{E}-19$ & $8.5 \mathrm{E}-05$ & $4.5 \mathrm{E}-04$ & $9.4 \mathrm{E}-05$ & $1.8 \mathrm{E}-05$ & $3.5 \mathrm{E}-06$ \\
\hline $\mathrm{E}$ & 1 & 1699 & $\mathrm{GC}$ & $0.0 \mathrm{E}+00$ & $0.0 \mathrm{E}+00$ & $0.0 \mathrm{E}+00$ & $0.0 \mathrm{E}+00$ & $0.0 \mathrm{E}+00$ & $0.0 \mathrm{E}+00$ & $3.8 \mathrm{E}-09$ & 2.7E-04 & $1.7 \mathrm{E}-04$ & $3.8 \mathrm{E}-05$ & $9.2 \mathrm{E}-06$ \\
\hline $\mathrm{F}$ & 1 & 1699 & GC & $0.0 \mathrm{E}+00$ & $0.0 \mathrm{E}+00$ & $0.0 \mathrm{E}+00$ & $0.0 \mathrm{E}+00$ & $0.0 \mathrm{E}+00$ & $0.0 \mathrm{E}+00$ & $1.0 \mathrm{E}-24$ & $5.6 \mathrm{E}-06$ & $2.5 \mathrm{E}-04$ & $9.1 \mathrm{E}-05$ & 2.4E-05 \\
\hline $\mathrm{A}$ & 3.4 & 1699 & GC & $0.0 \mathrm{E}+00$ & $0.0 \mathrm{E}+00$ & $0.0 \mathrm{E}+00$ & $0.0 \mathrm{E}+00$ & $3.2 \mathrm{E}-16$ & 4.9E-05 & $1.4 \mathrm{E}-04$ & $2.2 \mathrm{E}-05$ & $2.1 \mathrm{E}-06$ & $2.5 \mathrm{E}-07$ & $2.8 \mathrm{E}-08$ \\
\hline B & 3.4 & 1699 & GC & $0.0 \mathrm{E}+00$ & $0.0 \mathrm{E}+00$ & $0.0 \mathrm{E}+00$ & $0.0 \mathrm{E}+00$ & 7.6E-40 & $1.9 \mathrm{E}-07$ & $1.7 \mathrm{E}-04$ & 4.7E-05 & $4.8 \mathrm{E}-06$ & $5.8 \mathrm{E}-07$ & $6.5 \mathrm{E}-08$ \\
\hline $\mathrm{C}$ & 3.4 & 1699 & $\mathrm{GC}$ & $0.0 \mathrm{E}+00$ & $0.0 \mathrm{E}+00$ & $0.0 \mathrm{E}+00$ & $0.0 \mathrm{E}+00$ & $0.0 \mathrm{E}+00$ & $2.1 \mathrm{E}-12$ & $1.1 \mathrm{E}-04$ & $9.0 \mathrm{E}-05$ & $1.1 \mathrm{E}-05$ & $1.6 \mathrm{E}-06$ & $2.5 \mathrm{E}-07$ \\
\hline $\mathrm{D}$ & 3.4 & 1699 & GC & $0.0 \mathrm{E}+00$ & $0.0 \mathrm{E}+00$ & $0.0 \mathrm{E}+00$ & $0.0 \mathrm{E}+00$ & $0.0 \mathrm{E}+00$ & $4.1 \mathrm{E}-20$ & $2.5 \mathrm{E}-05$ & $1.3 \mathrm{E}-04$ & $2.8 \mathrm{E}-05$ & $5.3 \mathrm{E}-06$ & $1.0 \mathrm{E}-06$ \\
\hline $\mathrm{E}$ & 3.4 & 1699 & GC & $0.0 \mathrm{E}+00$ & $0.0 \mathrm{E}+00$ & $0.0 \mathrm{E}+00$ & $0.0 \mathrm{E}+00$ & $0.0 \mathrm{E}+00$ & $0.0 \mathrm{E}+00$ & $1.1 \mathrm{E}-09$ & $7.9 \mathrm{E}-05$ & $5.1 \mathrm{E}-05$ & $1.1 \mathrm{E}-05$ & $2.7 \mathrm{E}-06$ \\
\hline $\mathrm{F}$ & 3.4 & 1699 & GC & $0.0 \mathrm{E}+00$ & $0.0 \mathrm{E}+00$ & $0.0 \mathrm{E}+00$ & $0.0 \mathrm{E}+00$ & $0.0 \mathrm{E}+00$ & $0.0 \mathrm{E}+00$ & $3.1 \mathrm{E}-25$ & $1.6 \mathrm{E}-06$ & 7.5E-05 & $2.7 \mathrm{E}-05$ & 7.2E-06 \\
\hline $\mathrm{G}$ & 3.4 & 1699 & GC & $0.0 \mathrm{E}+00$ & $0.0 \mathrm{E}+00$ & $0.0 \mathrm{E}+00$ & $0.0 \mathrm{E}+00$ & $0.0 \mathrm{E}+00$ & $0.0 \mathrm{E}+00$ & $0.0 \mathrm{E}+00$ & $3.3 \mathrm{E}-13$ & $2.1 \mathrm{E}-05$ & $4.3 \mathrm{E}-05$ & $1.6 \mathrm{E}-05$ \\
\hline $\mathrm{C}$ & 10 & 1699 & GC & $0.0 \mathrm{E}+00$ & $0.0 \mathrm{E}+00$ & $0.0 \mathrm{E}+00$ & $0.0 \mathrm{E}+00$ & $0.0 \mathrm{E}+00$ & 7.2E-13 & $3.8 \mathrm{E}-05$ & $3.1 \mathrm{E}-05$ & $3.8 \mathrm{E}-06$ & $5.4 \mathrm{E}-07$ & 8.4E-08 \\
\hline $\mathrm{D}$ & 10 & 1699 & $\mathrm{GC}$ & $0.0 \mathrm{E}+00$ & $0.0 \mathrm{E}+00$ & $0.0 \mathrm{E}+00$ & $0.0 \mathrm{E}+00$ & $0.0 \mathrm{E}+00$ & $1.4 \mathrm{E}-20$ & $8.6 \mathrm{E}-06$ & $4.5 \mathrm{E}-05$ & $9.4 \mathrm{E}-06$ & $1.8 \mathrm{E}-06$ & $3.5 \mathrm{E}-07$ \\
\hline $\mathrm{E}$ & 10 & 1699 & $\mathrm{GC}$ & $0.0 \mathrm{E}+00$ & $0.0 \mathrm{E}+00$ & $0.0 \mathrm{E}+00$ & $0.0 \mathrm{E}+00$ & $0.0 \mathrm{E}+00$ & $0.0 \mathrm{E}+00$ & $3.8 \mathrm{E}-10$ & $2.7 \mathrm{E}-05$ & $1.7 \mathrm{E}-05$ & $3.8 \mathrm{E}-06$ & $9.2 \mathrm{E}-07$ \\
\hline $\mathrm{C}$ & 20 & 1699 & GC & $0.0 \mathrm{E}+00$ & $0.0 \mathrm{E}+00$ & $0.0 \mathrm{E}+00$ & $0.0 \mathrm{E}+00$ & $0.0 \mathrm{E}+00$ & $3.6 \mathrm{E}-13$ & $1.9 \mathrm{E}-05$ & $1.5 \mathrm{E}-05$ & $1.9 \mathrm{E}-06$ & $2.7 \mathrm{E}-07$ & $4.2 \mathrm{E}-08$ \\
\hline $\mathrm{D}$ & 20 & 1699 & $\mathrm{GC}$ & $0.0 \mathrm{E}+00$ & $0.0 \mathrm{E}+00$ & $0.0 \mathrm{E}+00$ & $0.0 \mathrm{E}+00$ & $0.0 \mathrm{E}+00$ & 7.0E-21 & 4.3E-06 & $2.3 \mathrm{E}-05$ & 4.7E-06 & $9.1 \mathrm{E}-07$ & $1.8 \mathrm{E}-07$ \\
\hline$E$ & 20 & 1699 & GC & $0.0 \mathrm{E}+00$ & $0.0 \mathrm{E}+00$ & $0.0 \mathrm{E}+00$ & $0.0 \mathrm{E}+00$ & $0.0 \mathrm{E}+00$ & $0.0 \mathrm{E}+00$ & $1.9 \mathrm{E}-10$ & $1.3 \mathrm{E}-05$ & $8.7 \mathrm{E}-06$ & $1.9 \mathrm{E}-06$ & $4.6 \mathrm{E}-07$ \\
\hline
\end{tabular}


Table A.6. (contd)

\begin{tabular}{|c|c|c|c|c|c|c|c|c|c|c|c|c|c|c|}
\hline \multirow{2}{*}{$\begin{array}{l}\text { Stability } \\
\text { Class }\end{array}$} & \multirow{2}{*}{$\begin{array}{l}\text { Wind } \\
\text { Speed } \\
\mathrm{m} / \mathrm{s}\end{array}$} & \multirow{2}{*}{$\begin{array}{c}\text { Venting } \\
\text { Rate } \\
\text { m3/hr }\end{array}$} & \multirow[b]{2}{*}{ Conc. } & \multicolumn{3}{|c|}{ Distance Downwind, $\mathbf{m}$} & \multirow[b]{2}{*}{3} & \multirow[b]{2}{*}{10} & \multirow[b]{2}{*}{30} & \multirow[b]{2}{*}{100} & \multirow[b]{2}{*}{300} & \multirow[b]{2}{*}{1000} & \multirow[b]{2}{*}{3000} & \multirow[b]{2}{*}{10,000} \\
\hline & & & & 0.001 & 0.3 & 1 & & & & & & & & \\
\hline A & 1 & 1699 & $\mathrm{CC}$ & $1.0 \mathrm{E}+00$ & $9.7 \mathrm{E}-01$ & 7.7E-01 & $2.8 \mathrm{E}-01$ & 3.3E-02 & $3.8 \mathrm{E}-03$ & 4.3E-04 & 7.1E-05 & 7.1E-06 & $8.6 \mathrm{E}-07$ & 9.7E-08 \\
\hline B & 1 & 1699 & $\mathrm{CC}$ & $1.0 \mathrm{E}+00$ & $9.9 \mathrm{E}-01$ & $8.9 \mathrm{E}-01$ & 4.7E-01 & 7.3E-02 & $8.6 \mathrm{E}-03$ & $8.0 \mathrm{E}-04$ & $1.5 \mathrm{E}-04$ & $1.6 \mathrm{E}-05$ & $2.0 \mathrm{E}-06$ & $2.2 \mathrm{E}-07$ \\
\hline $\mathrm{C}$ & 1 & 1699 & $\mathrm{CC}$ & $1.0 \mathrm{E}+00$ & $9.9 \mathrm{E}-01$ & $9.4 \mathrm{E}-01$ & $6.5 \mathrm{E}-01$ & $1.5 \mathrm{E}-01$ & $1.9 \mathrm{E}-02$ & $1.7 \mathrm{E}-03$ & 2.7E-04 & $3.7 \mathrm{E}-05$ & $5.4 \mathrm{E}-06$ & $8.4 \mathrm{E}-07$ \\
\hline $\mathrm{D}$ & 1 & 1699 & $\mathrm{CC}$ & $1.0 \mathrm{E}+00$ & $1.0 \mathrm{E}+00$ & $9.7 \mathrm{E}-01$ & $7.8 \mathrm{E}-01$ & $2.4 \mathrm{E}-01$ & $3.4 \mathrm{E}-02$ & $3.4 \mathrm{E}-03$ & $4.6 \mathrm{E}-04$ & $8.7 \mathrm{E}-05$ & $1.8 \mathrm{E}-05$ & $3.5 \mathrm{E}-06$ \\
\hline $\mathrm{E}$ & 1 & 1699 & $\mathrm{CC}$ & $1.0 \mathrm{E}+00$ & $1.0 \mathrm{E}+00$ & $9.9 \mathrm{E}-01$ & $9.0 \mathrm{E}-01$ & $4.6 \mathrm{E}-01$ & $8.6 \mathrm{E}-02$ & $8.6 \mathrm{E}-03$ & $1.0 \mathrm{E}-03$ & $1.5 \mathrm{E}-04$ & $3.6 \mathrm{E}-05$ & $9.0 \mathrm{E}-06$ \\
\hline $\mathrm{F}$ & 1 & 1699 & $\mathrm{CC}$ & $1.0 \mathrm{E}+00$ & $1.0 \mathrm{E}+00$ & $1.0 \mathrm{E}+00$ & $9.6 \mathrm{E}-01$ & 7.0E-01 & $2.1 \mathrm{E}-01$ & $2.4 \mathrm{E}-02$ & $2.9 \mathrm{E}-03$ & $3.3 \mathrm{E}-04$ & $8.0 \mathrm{E}-05$ & $2.3 \mathrm{E}-05$ \\
\hline A & 3.4 & 1699 & $\mathrm{CC}$ & $9.9 \mathrm{E}-01$ & $9.2 \mathrm{E}-01$ & $5.0 \mathrm{E}-01$ & $1.0 \mathrm{E}-01$ & $9.9 \mathrm{E}-03$ & $1.1 \mathrm{E}-03$ & $1.3 \mathrm{E}-04$ & $2.1 \mathrm{E}-05$ & $2.1 \mathrm{E}-06$ & $2.5 \mathrm{E}-07$ & $2.8 \mathrm{E}-08$ \\
\hline$B$ & 3.4 & 1699 & $\mathrm{CC}$ & $1.0 \mathrm{E}+00$ & $9.6 \mathrm{E}-01$ & 7.0E-01 & $2.0 \mathrm{E}-01$ & $2.3 \mathrm{E}-02$ & $2.6 \mathrm{E}-03$ & $2.4 \mathrm{E}-04$ & $4.3 \mathrm{E}-05$ & $4.7 \mathrm{E}-06$ & $5.8 \mathrm{E}-07$ & $6.5 \mathrm{E}-08$ \\
\hline $\mathrm{C}$ & 3.4 & 1699 & $\mathrm{CC}$ & $1.0 \mathrm{E}+00$ & $9.8 \mathrm{E}-01$ & $8.3 \mathrm{E}-01$ & 3.6E-01 & $4.8 \mathrm{E}-02$ & $5.6 \mathrm{E}-03$ & $5.1 \mathrm{E}-04$ & 7.9E-05 & $1.1 \mathrm{E}-05$ & $1.6 \mathrm{E}-06$ & $2.5 \mathrm{E}-07$ \\
\hline $\mathrm{D}$ & 3.4 & 1699 & $\mathrm{CC}$ & $1.0 \mathrm{E}+00$ & $9.9 \mathrm{E}-01$ & $9.0 \mathrm{E}-01$ & 5.1E-01 & $8.5 \mathrm{E}-02$ & $1.0 \mathrm{E}-02$ & $9.9 \mathrm{E}-04$ & $1.4 \mathrm{E}-04$ & $2.6 \mathrm{E}-05$ & $5.2 \mathrm{E}-06$ & $1.0 \mathrm{E}-06$ \\
\hline $\mathrm{E}$ & 3.4 & 1699 & $\mathrm{CC}$ & $1.0 \mathrm{E}+00$ & $9.9 \mathrm{E}-01$ & $9.6 \mathrm{E}-01$ & 7.3E-01 & $2.0 \mathrm{E}-01$ & $2.7 \mathrm{E}-02$ & $2.5 \mathrm{E}-03$ & $3.0 \mathrm{E}-04$ & $4.5 \mathrm{E}-05$ & $1.1 \mathrm{E}-05$ & 2.6E-06 \\
\hline $\mathrm{F}$ & 3.4 & 1699 & $\mathrm{CC}$ & $1.0 \mathrm{E}+00$ & $1.0 \mathrm{E}+00$ & $9.9 \mathrm{E}-01$ & $8.8 \mathrm{E}-01$ & $4.1 \mathrm{E}-01$ & 7.2E-02 & 7.1E-03 & $8.5 \mathrm{E}-04$ & $9.6 \mathrm{E}-05$ & $2.4 \mathrm{E}-05$ & $6.7 \mathrm{E}-06$ \\
\hline G & 3.4 & 1699 & $\mathrm{CC}$ & $1.0 \mathrm{E}+00$ & $1.0 \mathrm{E}+00$ & $9.9 \mathrm{E}-01$ & $9.6 \mathrm{E}-01$ & $6.6 \mathrm{E}-01$ & $1.8 \mathrm{E}-01$ & $2.0 \mathrm{E}-02$ & $2.4 \mathrm{E}-03$ & $2.6 \mathrm{E}-04$ & $4.8 \mathrm{E}-05$ & $1.4 \mathrm{E}-05$ \\
\hline $\mathrm{C}$ & 10 & 1699 & $\mathrm{CC}$ & $9.9 \mathrm{E}-01$ & $9.5 \mathrm{E}-01$ & $6.3 \mathrm{E}-01$ & $1.6 \mathrm{E}-01$ & $1.7 \mathrm{E}-02$ & $1.9 \mathrm{E}-03$ & $1.7 \mathrm{E}-04$ & $2.7 \mathrm{E}-05$ & $3.7 \mathrm{E}-06$ & $5.4 \mathrm{E}-07$ & $8.4 \mathrm{E}-08$ \\
\hline $\mathrm{D}$ & 10 & 1699 & $\mathrm{CC}$ & $1.0 \mathrm{E}+00$ & $9.7 \mathrm{E}-01$ & 7.6E-01 & $2.6 \mathrm{E}-01$ & $3.1 \mathrm{E}-02$ & $3.5 \mathrm{E}-03$ & $3.4 \mathrm{E}-04$ & $4.6 \mathrm{E}-05$ & $8.7 \mathrm{E}-06$ & $1.8 \mathrm{E}-06$ & $3.5 \mathrm{E}-07$ \\
\hline $\mathrm{E}$ & 10 & 1699 & $\mathrm{CC}$ & $1.0 \mathrm{E}+00$ & $9.8 \mathrm{E}-01$ & $8.9 \mathrm{E}-01$ & $4.8 \mathrm{E}-01$ & $7.7 \mathrm{E}-02$ & $9.3 \mathrm{E}-03$ & $8.6 \mathrm{E}-04$ & $1.0 \mathrm{E}-04$ & $1.5 \mathrm{E}-05$ & $3.6 \mathrm{E}-06$ & $9.0 \mathrm{E}-07$ \\
\hline B & 20 & 1699 & $\mathrm{CC}$ & $9.8 \mathrm{E}-01$ & $8.1 \mathrm{E}-01$ & $2.8 \mathrm{E}-01$ & $4.2 \mathrm{E}-02$ & $3.9 \mathrm{E}-03$ & $4.4 \mathrm{E}-04$ & $4.0 \mathrm{E}-05$ & $7.3 \mathrm{E}-06$ & $8.0 \mathrm{E}-07$ & $9.9 \mathrm{E}-08$ & $1.1 \mathrm{E}-08$ \\
\hline $\mathrm{C}$ & 20 & 1699 & $\mathrm{CC}$ & $9.9 \mathrm{E}-01$ & $9.0 \mathrm{E}-01$ & 4.6E-01 & $8.7 \mathrm{E}-02$ & $8.5 \mathrm{E}-03$ & $9.5 \mathrm{E}-04$ & 8.7E-05 & $1.3 \mathrm{E}-05$ & $1.9 \mathrm{E}-06$ & $2.7 \mathrm{E}-07$ & $4.2 \mathrm{E}-08$ \\
\hline $\mathrm{D}$ & 20 & 1699 & $\mathrm{CC}$ & $9.9 \mathrm{E}-01$ & $9.4 \mathrm{E}-01$ & $6.1 \mathrm{E}-01$ & $1.5 \mathrm{E}-01$ & $1.6 \mathrm{E}-02$ & $1.8 \mathrm{E}-03$ & $1.7 \mathrm{E}-04$ & $2.3 \mathrm{E}-05$ & $4.4 \mathrm{E}-06$ & $8.9 \mathrm{E}-07$ & $1.7 \mathrm{E}-07$ \\
\hline E & 20 & 1699 & $\mathrm{CC}$ & $1.0 \mathrm{E}+00$ & $9.7 \mathrm{E}-01$ & 8.1E-01 & $3.2 \mathrm{E}-01$ & $4.0 \mathrm{E}-02$ & 4.7E-03 & 4.3E-04 & $5.1 \mathrm{E}-05$ & 7.7E-06 & $1.8 \mathrm{E}-06$ & $4.5 \mathrm{E}-07$ \\
\hline
\end{tabular}


Table A.7. SY Farm Existing Vent; Fractional Concentrations at Ground Level (GC) and Plume Centerline (CC)

\begin{tabular}{|c|c|c|c|c|c|c|c|c|c|c|c|c|c|c|}
\hline \multirow{2}{*}{$\begin{array}{c}\text { Stability } \\
\text { Class }\end{array}$} & \multirow{2}{*}{$\begin{array}{c}\text { Wind } \\
\text { Speed } \\
\text { m/s }\end{array}$} & \multirow{2}{*}{$\begin{array}{c}\text { Venting } \\
\text { Rate } \\
\text { m3/hr }\end{array}$} & \multirow[b]{2}{*}{ Conc. } & \multicolumn{3}{|c|}{ Distance Downwind, m } & \multirow[b]{2}{*}{3} & \multirow[b]{2}{*}{10} & \multirow[b]{2}{*}{30} & \multirow[b]{2}{*}{100} & \multirow[b]{2}{*}{300} & \multirow[b]{2}{*}{1000} & \multirow[b]{2}{*}{3000} & \multirow[b]{2}{*}{10,000} \\
\hline & & & & 0.001 & 0.3 & 1 & & & & & & & & \\
\hline A & 1 & 1359 & GC & $0.0 \mathrm{E}+00$ & $0.0 \mathrm{E}+00$ & $0.0 \mathrm{E}+00$ & $1.1 \mathrm{E}-12$ & 2.7E-03 & 4.1E-03 & $5.3 \mathrm{E}-04$ & $6.1 \mathrm{E}-05$ & $5.7 \mathrm{E}-06$ & $6.9 \mathrm{E}-07$ & 7.7E-08 \\
\hline $\mathrm{B}$ & 1 & 1359 & GC & $0.0 \mathrm{E}+00$ & $0.0 \mathrm{E}+00$ & $0.0 \mathrm{E}+00$ & $1.4 \mathrm{E}-32$ & $8.7 \mathrm{E}-05$ & $4.8 \mathrm{E}-03$ & $1.1 \mathrm{E}-03$ & $1.4 \mathrm{E}-04$ & $1.3 \mathrm{E}-05$ & $1.6 \mathrm{E}-06$ & $1.8 \mathrm{E}-07$ \\
\hline $\mathrm{C}$ & 1 & 1359 & GC & $0.0 \mathrm{E}+00$ & $0.0 \mathrm{E}+00$ & $0.0 \mathrm{E}+00$ & $0.0 \mathrm{E}+00$ & 4.9E-08 & $3.4 \mathrm{E}-03$ & $2.2 \mathrm{E}-03$ & $3.1 \mathrm{E}-04$ & $3.1 \mathrm{E}-05$ & 4.4E-06 & 6.7E-07 \\
\hline $\mathrm{D}$ & 1 & 1359 & $\mathrm{GC}$ & $0.0 \mathrm{E}+00$ & $0.0 \mathrm{E}+00$ & $0.0 \mathrm{E}+00$ & $0.0 \mathrm{E}+00$ & $6.4 \mathrm{E}-13$ & $1.4 \mathrm{E}-03$ & $3.4 \mathrm{E}-03$ & $6.4 \mathrm{E}-04$ & $8.2 \mathrm{E}-05$ & $1.5 \mathrm{E}-05$ & $2.8 \mathrm{E}-06$ \\
\hline $\mathrm{E}$ & 1 & 1359 & $\mathrm{GC}$ & $0.0 \mathrm{E}+00$ & $0.0 \mathrm{E}+00$ & $0.0 \mathrm{E}+00$ & $0.0 \mathrm{E}+00$ & $1.0 \mathrm{E}-46$ & $5.2 \mathrm{E}-07$ & $2.9 \mathrm{E}-03$ & $1.3 \mathrm{E}-03$ & $1.8 \mathrm{E}-04$ & $3.2 \mathrm{E}-05$ & $7.5 \mathrm{E}-06$ \\
\hline $\mathrm{F}$ & 1 & 1359 & GC & $0.0 \mathrm{E}+00$ & $0.0 \mathrm{E}+00$ & $0.0 \mathrm{E}+00$ & $0.0 \mathrm{E}+00$ & $0.0 \mathrm{E}+00$ & $1.7 \mathrm{E}-19$ & $3.9 \mathrm{E}-04$ & $2.2 \mathrm{E}-03$ & $4.6 \mathrm{E}-04$ & $8.8 \mathrm{E}-05$ & 2.1E-05 \\
\hline A & 3.4 & 1359 & GC & $0.0 \mathrm{E}+00$ & $0.0 \mathrm{E}+00$ & $0.0 \mathrm{E}+00$ & $3.8 \mathrm{E}-13$ & 8.1E-04 & $1.2 \mathrm{E}-03$ & $1.6 \mathrm{E}-04$ & $1.8 \mathrm{E}-05$ & $1.7 \mathrm{E}-06$ & $2.0 \mathrm{E}-07$ & 2.3E-08 \\
\hline B & 3.4 & 1359 & GC & $0.0 \mathrm{E}+00$ & $0.0 \mathrm{E}+00$ & $0.0 \mathrm{E}+00$ & $5.7 \mathrm{E}-33$ & 2.7E-05 & $1.4 \mathrm{E}-03$ & $3.3 \mathrm{E}-04$ & $4.1 \mathrm{E}-05$ & $3.9 \mathrm{E}-06$ & 4.7E-07 & $5.2 \mathrm{E}-08$ \\
\hline $\mathrm{C}$ & 3.4 & 1359 & $\mathrm{GC}$ & $0.0 \mathrm{E}+00$ & $0.0 \mathrm{E}+00$ & $0.0 \mathrm{E}+00$ & $0.0 \mathrm{E}+00$ & $1.6 \mathrm{E}-08$ & $1.0 \mathrm{E}-03$ & $6.5 \mathrm{E}-04$ & $9.1 \mathrm{E}-05$ & $9.2 \mathrm{E}-06$ & $1.3 \mathrm{E}-06$ & $2.0 \mathrm{E}-07$ \\
\hline $\mathrm{D}$ & 3.4 & 1359 & GC & $0.0 \mathrm{E}+00$ & $0.0 \mathrm{E}+00$ & $0.0 \mathrm{E}+00$ & $0.0 \mathrm{E}+00$ & $2.2 \mathrm{E}-13$ & 4.1E-04 & $1.0 \mathrm{E}-03$ & $1.9 \mathrm{E}-04$ & $2.4 \mathrm{E}-05$ & 4.4E-06 & 8.3E-07 \\
\hline $\mathrm{E}$ & 3.4 & 1359 & GC & $0.0 \mathrm{E}+00$ & $0.0 \mathrm{E}+00$ & $0.0 \mathrm{E}+00$ & $0.0 \mathrm{E}+00$ & $4.2 \mathrm{E}-47$ & $1.6 \mathrm{E}-07$ & $8.6 \mathrm{E}-04$ & $3.9 \mathrm{E}-04$ & $5.2 \mathrm{E}-05$ & $9.4 \mathrm{E}-06$ & $2.2 \mathrm{E}-06$ \\
\hline$F$ & 3.4 & 1359 & GC & $0.0 \mathrm{E}+00$ & $0.0 \mathrm{E}+00$ & $0.0 \mathrm{E}+00$ & $0.0 \mathrm{E}+00$ & $0.0 \mathrm{E}+00$ & $5.5 \mathrm{E}-20$ & $1.2 \mathrm{E}-04$ & $6.6 \mathrm{E}-04$ & $1.4 \mathrm{E}-04$ & $2.6 \mathrm{E}-05$ & $6.2 \mathrm{E}-06$ \\
\hline $\mathrm{G}$ & 3.4 & 1359 & GC & $0.0 \mathrm{E}+00$ & $0.0 \mathrm{E}+00$ & $0.0 \mathrm{E}+00$ & $0.0 \mathrm{E}+00$ & $0.0 \mathrm{E}+00$ & $0.0 \mathrm{E}+00$ & $1.6 \mathrm{E}-08$ & $3.9 \mathrm{E}-04$ & $3.0 \mathrm{E}-04$ & $6.8 \mathrm{E}-05$ & $1.7 \mathrm{E}-05$ \\
\hline $\mathrm{C}$ & 10 & 1359 & GC & $0.0 \mathrm{E}+00$ & $0.0 \mathrm{E}+00$ & $0.0 \mathrm{E}+00$ & $0.0 \mathrm{E}+00$ & $5.5 \mathrm{E}-09$ & $3.4 \mathrm{E}-04$ & $2.2 \mathrm{E}-04$ & $3.1 \mathrm{E}-05$ & $3.1 \mathrm{E}-06$ & 4.4E-07 & 6.7E-08 \\
\hline $\mathrm{D}$ & 10 & 1359 & $\mathrm{GC}$ & $0.0 \mathrm{E}+00$ & $0.0 \mathrm{E}+00$ & $0.0 \mathrm{E}+00$ & $0.0 \mathrm{E}+00$ & $7.8 \mathrm{E}-14$ & $1.4 \mathrm{E}-04$ & 3.4E-04 & $6.4 \mathrm{E}-05$ & $8.2 \mathrm{E}-06$ & $1.5 \mathrm{E}-06$ & $2.8 \mathrm{E}-07$ \\
\hline $\mathrm{E}$ & 10 & 1359 & GC & $0.0 \mathrm{E}+00$ & $0.0 \mathrm{E}+00$ & $0.0 \mathrm{E}+00$ & $0.0 \mathrm{E}+00$ & $1.6 \mathrm{E}-47$ & $5.6 \mathrm{E}-08$ & $2.9 \mathrm{E}-04$ & $1.3 \mathrm{E}-04$ & $1.8 \mathrm{E}-05$ & $3.2 \mathrm{E}-06$ & $7.5 \mathrm{E}-07$ \\
\hline $\mathrm{C}$ & 20 & 1359 & GC & $0.0 \mathrm{E}+00$ & $0.0 \mathrm{E}+00$ & $0.0 \mathrm{E}+00$ & $0.0 \mathrm{E}+00$ & $2.8 \mathrm{E}-09$ & $1.7 \mathrm{E}-04$ & $1.1 \mathrm{E}-04$ & $1.5 \mathrm{E}-05$ & $1.6 \mathrm{E}-06$ & $2.2 \mathrm{E}-07$ & $3.3 \mathrm{E}-08$ \\
\hline $\mathrm{D}$ & 20 & 1359 & $\mathrm{GC}$ & $0.0 \mathrm{E}+00$ & $0.0 \mathrm{E}+00$ & $0.0 \mathrm{E}+00$ & $0.0 \mathrm{E}+00$ & $3.9 \mathrm{E}-14$ & 7.1E-05 & $1.7 \mathrm{E}-04$ & $3.2 \mathrm{E}-05$ & 4.1E-06 & 7.4E-07 & $1.4 \mathrm{E}-07$ \\
\hline$E$ & 20 & 1359 & GC & $0.0 \mathrm{E}+00$ & $0.0 \mathrm{E}+00$ & $0.0 \mathrm{E}+00$ & $0.0 \mathrm{E}+00$ & $8.3 \mathrm{E}-48$ & $2.8 \mathrm{E}-08$ & $1.5 \mathrm{E}-04$ & $6.6 \mathrm{E}-05$ & $8.9 \mathrm{E}-06$ & $1.6 \mathrm{E}-06$ & $3.8 \mathrm{E}-07$ \\
\hline
\end{tabular}


Table A.7. (contd)

\begin{tabular}{|c|c|c|c|c|c|c|c|c|c|c|c|c|c|c|}
\hline \multirow{2}{*}{$\begin{array}{c}\text { Stability } \\
\text { Class }\end{array}$} & \multirow{2}{*}{$\begin{array}{l}\text { Wind } \\
\text { Speed } \\
\mathrm{m} / \mathrm{s}\end{array}$} & \multirow{2}{*}{$\begin{array}{c}\text { Venting } \\
\text { Rate } \\
\text { m3/hr }\end{array}$} & \multirow[b]{2}{*}{ Conc. } & \multicolumn{3}{|c|}{ Distance Downwind, $\mathbf{m}$} & \multirow[b]{2}{*}{3} & \multirow[b]{2}{*}{10} & \multirow[b]{2}{*}{30} & \multirow[b]{2}{*}{100} & \multirow[b]{2}{*}{300} & \multirow[b]{2}{*}{1000} & \multirow[b]{2}{*}{3000} & \multirow[b]{2}{*}{10,000} \\
\hline & & & & 0.001 & 0.3 & 1 & & & & & & & & \\
\hline A & 1 & 1359 & $\mathrm{CC}$ & $1.0 \mathrm{E}+00$ & $9.7 \mathrm{E}-01$ & 7.3E-01 & $2.3 \mathrm{E}-01$ & $2.7 \mathrm{E}-02$ & $3.7 \mathrm{E}-03$ & $5.1 \mathrm{E}-04$ & $6.1 \mathrm{E}-05$ & 5.7E-06 & $6.9 \mathrm{E}-07$ & 7.7E-08 \\
\hline B & 1 & 1359 & $\mathrm{CC}$ & $1.0 \mathrm{E}+00$ & $9.9 \mathrm{E}-01$ & $8.6 \mathrm{E}-01$ & $4.1 \mathrm{E}-01$ & $5.9 \mathrm{E}-02$ & $7.0 \mathrm{E}-03$ & $1.1 \mathrm{E}-03$ & $1.4 \mathrm{E}-04$ & $1.3 \mathrm{E}-05$ & $1.6 \mathrm{E}-06$ & $1.8 \mathrm{E}-07$ \\
\hline $\mathrm{C}$ & 1 & 1359 & $\mathrm{CC}$ & $1.0 \mathrm{E}+00$ & $9.9 \mathrm{E}-01$ & $9.3 \mathrm{E}-01$ & $6.0 \mathrm{E}-01$ & $1.2 \mathrm{E}-01$ & $1.5 \mathrm{E}-02$ & $1.9 \mathrm{E}-03$ & $3.0 \mathrm{E}-04$ & $3.1 \mathrm{E}-05$ & $4.4 \mathrm{E}-06$ & $6.7 \mathrm{E}-07$ \\
\hline $\mathrm{D}$ & 1 & 1359 & $\mathrm{CC}$ & $1.0 \mathrm{E}+00$ & $1.0 \mathrm{E}+00$ & $9.6 \mathrm{E}-01$ & 7.4E-01 & $2.0 \mathrm{E}-01$ & $2.8 \mathrm{E}-02$ & $3.1 \mathrm{E}-03$ & $6.0 \mathrm{E}-04$ & $8.1 \mathrm{E}-05$ & $1.5 \mathrm{E}-05$ & $2.8 \mathrm{E}-06$ \\
\hline $\bar{E}$ & 1 & 1359 & $\mathrm{CC}$ & $1.0 \mathrm{E}+00$ & $1.0 \mathrm{E}+00$ & $9.9 \mathrm{E}-01$ & $8.8 \mathrm{E}-01$ & $4.0 \mathrm{E}-01$ & $7.0 \mathrm{E}-02$ & $6.9 \mathrm{E}-03$ & $1.2 \mathrm{E}-03$ & $1.7 \mathrm{E}-04$ & 3.2E-05 & $7.5 \mathrm{E}-06$ \\
\hline$F$ & 1 & 1359 & $\mathrm{CC}$ & $1.0 \mathrm{E}+00$ & $1.0 \mathrm{E}+00$ & $9.9 \mathrm{E}-01$ & $9.5 \mathrm{E}-01$ & $6.5 \mathrm{E}-01$ & $1.7 \mathrm{E}-01$ & $1.9 \mathrm{E}-02$ & $2.4 \mathrm{E}-03$ & $4.3 \mathrm{E}-04$ & $8.7 \mathrm{E}-05$ & $2.1 \mathrm{E}-05$ \\
\hline A & 3.4 & 1359 & $\mathrm{CC}$ & $9.9 \mathrm{E}-01$ & $9.0 \mathrm{E}-01$ & $4.5 \mathrm{E}-01$ & $8.2 \mathrm{E}-02$ & $8.0 \mathrm{E}-03$ & $1.1 \mathrm{E}-03$ & $1.5 \mathrm{E}-04$ & $1.8 \mathrm{E}-05$ & $1.7 \mathrm{E}-06$ & $2.0 \mathrm{E}-07$ & $2.3 \mathrm{E}-08$ \\
\hline B & 3.4 & 1359 & $\mathrm{CC}$ & $9.9 \mathrm{E}-01$ & $9.5 \mathrm{E}-01$ & $6.5 \mathrm{E}-01$ & $1.7 \mathrm{E}-01$ & $1.8 \mathrm{E}-02$ & $2.1 \mathrm{E}-03$ & $3.1 \mathrm{E}-04$ & $4.1 \mathrm{E}-05$ & $3.9 \mathrm{E}-06$ & $4.7 \mathrm{E}-07$ & $5.2 \mathrm{E}-08$ \\
\hline $\mathrm{C}$ & 3.4 & 1359 & $\mathrm{CC}$ & $1.0 \mathrm{E}+00$ & $9.8 \mathrm{E}-01$ & $8.0 \mathrm{E}-01$ & $3.1 \mathrm{E}-01$ & $3.9 \mathrm{E}-02$ & $4.5 \mathrm{E}-03$ & 5.7E-04 & $8.9 \mathrm{E}-05$ & $9.2 \mathrm{E}-06$ & $1.3 \mathrm{E}-06$ & $2.0 \mathrm{E}-07$ \\
\hline $\mathrm{D}$ & 3.4 & 1359 & $\mathrm{CC}$ & $1.0 \mathrm{E}+00$ & $9.9 \mathrm{E}-01$ & $8.8 \mathrm{E}-01$ & $4.5 \mathrm{E}-01$ & $6.9 \mathrm{E}-02$ & $8.3 \mathrm{E}-03$ & $9.2 \mathrm{E}-04$ & $1.8 \mathrm{E}-04$ & $2.4 \mathrm{E}-05$ & $4.4 \mathrm{E}-06$ & $8.3 \mathrm{E}-07$ \\
\hline $\mathrm{E}$ & 3.4 & 1359 & $\mathrm{CC}$ & $1.0 \mathrm{E}+00$ & $1.0 \mathrm{E}+00$ & $9.5 \mathrm{E}-01$ & $6.9 \mathrm{E}-01$ & $1.6 \mathrm{E}-01$ & $2.2 \mathrm{E}-02$ & $2.0 \mathrm{E}-03$ & $3.5 \mathrm{E}-04$ & 5.1E-05 & $9.3 \mathrm{E}-06$ & $2.2 \mathrm{E}-06$ \\
\hline $\mathrm{F}$ & 3.4 & 1359 & $\mathrm{CC}$ & $1.0 \mathrm{E}+00$ & $1.0 \mathrm{E}+00$ & $9.8 \mathrm{E}-01$ & $8.6 \mathrm{E}-01$ & $3.6 \mathrm{E}-01$ & $5.8 \mathrm{E}-02$ & $5.7 \mathrm{E}-03$ & 7.1E-04 & $1.3 \mathrm{E}-04$ & $2.5 \mathrm{E}-05$ & $6.1 \mathrm{E}-06$ \\
\hline$G$ & 3.4 & 1359 & $\mathrm{CC}$ & $1.0 \mathrm{E}+00$ & $1.0 \mathrm{E}+00$ & $9.9 \mathrm{E}-01$ & 9.4E-01 & $6.1 \mathrm{E}-01$ & $1.5 \mathrm{E}-01$ & $1.6 \mathrm{E}-02$ & $1.9 \mathrm{E}-03$ & 2.7E-04 & 6.4E-05 & $1.6 \mathrm{E}-05$ \\
\hline $\mathrm{C}$ & 10 & 1359 & $\mathrm{CC}$ & $9.9 \mathrm{E}-01$ & $9.4 \mathrm{E}-01$ & $5.8 \mathrm{E}-01$ & $1.3 \mathrm{E}-01$ & $1.3 \mathrm{E}-02$ & $1.5 \mathrm{E}-03$ & $1.9 \mathrm{E}-04$ & $3.0 \mathrm{E}-05$ & $3.1 \mathrm{E}-06$ & $4.4 \mathrm{E}-07$ & $6.7 \mathrm{E}-08$ \\
\hline $\mathrm{D}$ & 10 & 1359 & $\overline{C C}$ & $1.0 \mathrm{E}+00$ & $9.7 \mathrm{E}-01$ & 7.1E-01 & $2.2 \mathrm{E}-01$ & $2.5 \mathrm{E}-02$ & $2.8 \mathrm{E}-03$ & $3.1 \mathrm{E}-04$ & $6.0 \mathrm{E}-05$ & $8.1 \mathrm{E}-06$ & $1.5 \mathrm{E}-06$ & $2.8 \mathrm{E}-07$ \\
\hline $\mathrm{E}$ & 10 & 1359 & $\mathrm{CC}$ & $1.0 \mathrm{E}+00$ & $9.9 \mathrm{E}-01$ & $8.7 \mathrm{E}-01$ & $4.3 \mathrm{E}-01$ & $6.3 \mathrm{E}-02$ & $7.4 \mathrm{E}-03$ & $6.9 \mathrm{E}-04$ & $1.2 \mathrm{E}-04$ & $1.7 \mathrm{E}-05$ & $3.2 \mathrm{E}-06$ & $7.5 \mathrm{E}-07$ \\
\hline $\bar{C}$ & 20 & 1359 & $\mathrm{CC}$ & $9.9 \mathrm{E}-01$ & $8.8 \mathrm{E}-01$ & $4.1 \mathrm{E}-01$ & 7.1E-02 & $6.8 \mathrm{E}-03$ & 7.6E-04 & $9.7 \mathrm{E}-05$ & $1.5 \mathrm{E}-05$ & $1.6 \mathrm{E}-06$ & $2.2 \mathrm{E}-07$ & $3.3 \mathrm{E}-08$ \\
\hline $\mathrm{D}$ & 20 & 1359 & $\mathrm{CC}$ & $9.9 \mathrm{E}-01$ & $9.3 \mathrm{E}-01$ & $5.6 \mathrm{E}-01$ & $1.2 \mathrm{E}-01$ & $1.2 \mathrm{E}-02$ & $1.4 \mathrm{E}-03$ & $1.6 \mathrm{E}-04$ & $3.0 \mathrm{E}-05$ & $4.1 \mathrm{E}-06$ & 7.4E-07 & $1.4 \mathrm{E}-07$ \\
\hline $\bar{E}$ & 20 & 1359 & $\overline{\mathrm{CC}}$ & $1.0 \mathrm{E}+00$ & $9.7 \mathrm{E}-01$ & 7.7E-01 & $2.7 \mathrm{E}-01$ & $3.2 \mathrm{E}-02$ & $3.7 \mathrm{E}-03$ & $3.5 \mathrm{E}-04$ & $5.9 \mathrm{E}-05$ & $8.6 \mathrm{E}-06$ & $1.6 \mathrm{E}-06$ & $3.8 \mathrm{E}-07$ \\
\hline
\end{tabular}


Table A.8. 242A Evaporator Stack; Fractional Concentrations at Ground Level (GC) and Plume Centerline (CC)

\begin{tabular}{|c|c|c|c|c|c|c|c|c|c|c|c|c|c|c|}
\hline \multirow{2}{*}{$\begin{array}{c}\text { Stability } \\
\text { Class }\end{array}$} & \multirow{2}{*}{$\begin{array}{c}\text { Wind } \\
\text { Speed } \\
\text { m/s }\end{array}$} & \multirow{2}{*}{$\begin{array}{c}\text { Venting } \\
\text { Rate } \\
\text { m3/hr }\end{array}$} & \multirow[b]{2}{*}{ Conc. } & \multicolumn{3}{|c|}{ Distance Downwind, m } & \multirow[b]{2}{*}{3} & \multirow[b]{2}{*}{10} & \multirow[b]{2}{*}{30} & \multirow[b]{2}{*}{100} & \multirow[b]{2}{*}{300} & \multirow[b]{2}{*}{1000} & \multirow[b]{2}{*}{3000} & \multirow[b]{2}{*}{10,000} \\
\hline & & & & 0.001 & 0.3 & 1 & & & & & & & & \\
\hline A & 1 & 1189 & GC & $0.0 \mathrm{E}+00$ & $0.0 \mathrm{E}+00$ & $0.0 \mathrm{E}+00$ & $0.0 \mathrm{E}+00$ & $9.5 \mathrm{E}-20$ & 4.2E-05 & $3.1 \mathrm{E}-04$ & $5.1 \mathrm{E}-05$ & $5.0 \mathrm{E}-06$ & $6.1 \mathrm{E}-07$ & $6.8 \mathrm{E}-08$ \\
\hline $\mathrm{B}$ & 1 & 1189 & GC & $0.0 \mathrm{E}+00$ & $0.0 \mathrm{E}+00$ & $0.0 \mathrm{E}+00$ & $0.0 \mathrm{E}+00$ & $2.6 \mathrm{E}-50$ & 2.7E-08 & $3.2 \mathrm{E}-04$ & $1.1 \mathrm{E}-04$ & $1.1 \mathrm{E}-05$ & $1.4 \mathrm{E}-06$ & $1.5 \mathrm{E}-07$ \\
\hline $\mathrm{C}$ & 1 & 1189 & GC & $0.0 \mathrm{E}+00$ & $0.0 \mathrm{E}+00$ & $0.0 \mathrm{E}+00$ & $0.0 \mathrm{E}+00$ & $0.0 \mathrm{E}+00$ & $9.4 \mathrm{E}-15$ & $1.5 \mathrm{E}-04$ & $2.0 \mathrm{E}-04$ & 2.7E-05 & $3.8 \mathrm{E}-06$ & $5.8 \mathrm{E}-07$ \\
\hline $\mathrm{D}$ & 1 & 1189 & $\mathrm{GC}$ & $0.0 \mathrm{E}+00$ & $0.0 \mathrm{E}+00$ & $0.0 \mathrm{E}+00$ & $0.0 \mathrm{E}+00$ & $0.0 \mathrm{E}+00$ & $8.9 \mathrm{E}-25$ & $1.8 \mathrm{E}-05$ & 2.7E-04 & $6.4 \mathrm{E}-05$ & $1.3 \mathrm{E}-05$ & $2.5 \mathrm{E}-06$ \\
\hline $\mathrm{E}$ & 1 & 1189 & $\mathrm{GC}$ & $0.0 \mathrm{E}+00$ & $0.0 \mathrm{E}+00$ & $0.0 \mathrm{E}+00$ & $0.0 \mathrm{E}+00$ & $0.0 \mathrm{E}+00$ & $0.0 \mathrm{E}+00$ & $3.8 \mathrm{E}-11$ & $1.1 \mathrm{E}-04$ & $1.1 \mathrm{E}-04$ & $2.6 \mathrm{E}-05$ & $6.4 \mathrm{E}-06$ \\
\hline $\mathrm{F}$ & 1 & 1189 & GC & $0.0 \mathrm{E}+00$ & $0.0 \mathrm{E}+00$ & $0.0 \mathrm{E}+00$ & $0.0 \mathrm{E}+00$ & $0.0 \mathrm{E}+00$ & $0.0 \mathrm{E}+00$ & $2.5 \mathrm{E}-31$ & $6.0 \mathrm{E}-07$ & $1.4 \mathrm{E}-04$ & $6.0 \mathrm{E}-05$ & $1.7 \mathrm{E}-05$ \\
\hline $\mathrm{A}$ & 3.4 & 1189 & GC & $0.0 \mathrm{E}+00$ & $0.0 \mathrm{E}+00$ & $0.0 \mathrm{E}+00$ & $0.0 \mathrm{E}+00$ & $2.8 \mathrm{E}-20$ & $1.2 \mathrm{E}-05$ & $9.0 \mathrm{E}-05$ & $1.5 \mathrm{E}-05$ & $1.5 \mathrm{E}-06$ & $1.8 \mathrm{E}-07$ & $2.0 \mathrm{E}-08$ \\
\hline B & 3.4 & 1189 & GC & $0.0 \mathrm{E}+00$ & $0.0 \mathrm{E}+00$ & $0.0 \mathrm{E}+00$ & $0.0 \mathrm{E}+00$ & $0.0 \mathrm{E}+00$ & 8.1E-09 & $9.4 \mathrm{E}-05$ & $3.2 \mathrm{E}-05$ & 3.3E-06 & 4.1E-07 & 4.6E-08 \\
\hline $\mathrm{C}$ & 3.4 & 1189 & $\mathrm{GC}$ & $0.0 \mathrm{E}+00$ & $0.0 \mathrm{E}+00$ & $0.0 \mathrm{E}+00$ & $0.0 \mathrm{E}+00$ & $0.0 \mathrm{E}+00$ & $2.8 \mathrm{E}-15$ & $4.3 \mathrm{E}-05$ & $5.9 \mathrm{E}-05$ & $7.8 \mathrm{E}-06$ & $1.1 \mathrm{E}-06$ & $1.7 \mathrm{E}-07$ \\
\hline $\mathrm{D}$ & 3.4 & 1189 & GC & $0.0 \mathrm{E}+00$ & $0.0 \mathrm{E}+00$ & $0.0 \mathrm{E}+00$ & $0.0 \mathrm{E}+00$ & $0.0 \mathrm{E}+00$ & $2.7 \mathrm{E}-25$ & $5.4 \mathrm{E}-06$ & 7.9E-05 & $1.9 \mathrm{E}-05$ & $3.7 \mathrm{E}-06$ & 7.2E-07 \\
\hline $\mathrm{E}$ & 3.4 & 1189 & GC & $0.0 \mathrm{E}+00$ & $0.0 \mathrm{E}+00$ & $0.0 \mathrm{E}+00$ & $0.0 \mathrm{E}+00$ & $0.0 \mathrm{E}+00$ & $0.0 \mathrm{E}+00$ & $1.1 \mathrm{E}-11$ & $3.2 \mathrm{E}-05$ & $3.3 \mathrm{E}-05$ & $7.6 \mathrm{E}-06$ & $1.9 \mathrm{E}-06$ \\
\hline$F$ & 3.4 & 1189 & GC & $0.0 \mathrm{E}+00$ & $0.0 \mathrm{E}+00$ & $0.0 \mathrm{E}+00$ & $0.0 \mathrm{E}+00$ & $0.0 \mathrm{E}+00$ & $0.0 \mathrm{E}+00$ & 7.4E-32 & $1.8 \mathrm{E}-07$ & 4.1E-05 & $1.8 \mathrm{E}-05$ & 4.9E-06 \\
\hline $\mathrm{G}$ & 3.4 & 1189 & GC & $0.0 \mathrm{E}+00$ & $0.0 \mathrm{E}+00$ & $0.0 \mathrm{E}+00$ & $0.0 \mathrm{E}+00$ & $0.0 \mathrm{E}+00$ & $0.0 \mathrm{E}+00$ & $0.0 \mathrm{E}+00$ & $3.2 \mathrm{E}-16$ & $6.1 \mathrm{E}-06$ & $2.4 \mathrm{E}-05$ & $1.0 \mathrm{E}-05$ \\
\hline $\mathrm{D}$ & 10 & 1189 & GC & $0.0 \mathrm{E}+00$ & $0.0 \mathrm{E}+00$ & $0.0 \mathrm{E}+00$ & $0.0 \mathrm{E}+00$ & $0.0 \mathrm{E}+00$ & $9.1 \mathrm{E}-26$ & $1.8 \mathrm{E}-06$ & 2.7E-05 & $6.4 \mathrm{E}-06$ & $1.3 \mathrm{E}-06$ & $2.5 \mathrm{E}-07$ \\
\hline $\mathrm{E}$ & 10 & 1189 & $\mathrm{GC}$ & $0.0 \mathrm{E}+00$ & $0.0 \mathrm{E}+00$ & $0.0 \mathrm{E}+00$ & $0.0 \mathrm{E}+00$ & $0.0 \mathrm{E}+00$ & $0.0 \mathrm{E}+00$ & $3.9 \mathrm{E}-12$ & $1.1 \mathrm{E}-05$ & $1.1 \mathrm{E}-05$ & $2.6 \mathrm{E}-06$ & $6.4 \mathrm{E}-07$ \\
\hline B & 20 & 1189 & $\mathrm{GC}$ & $0.0 \mathrm{E}+00$ & $0.0 \mathrm{E}+00$ & $0.0 \mathrm{E}+00$ & $0.0 \mathrm{E}+00$ & $0.0 \mathrm{E}+00$ & $1.4 \mathrm{E}-09$ & $1.6 \mathrm{E}-05$ & $5.4 \mathrm{E}-06$ & 5.7E-07 & $6.9 \mathrm{E}-08$ & 7.7E-09 \\
\hline $\mathrm{C}$ & 20 & 1189 & GC & $0.0 \mathrm{E}+00$ & $0.0 \mathrm{E}+00$ & $0.0 \mathrm{E}+00$ & $0.0 \mathrm{E}+00$ & $0.0 \mathrm{E}+00$ & $4.7 \mathrm{E}-16$ & 7.3E-06 & $1.0 \mathrm{E}-05$ & $1.3 \mathrm{E}-06$ & $1.9 \mathrm{E}-07$ & $2.9 \mathrm{E}-08$ \\
\hline $\mathrm{D}$ & 20 & 1189 & $\mathrm{GC}$ & $0.0 \mathrm{E}+00$ & $0.0 \mathrm{E}+00$ & $0.0 \mathrm{E}+00$ & $0.0 \mathrm{E}+00$ & $0.0 \mathrm{E}+00$ & 4.6E-26 & $9.2 \mathrm{E}-07$ & $1.3 \mathrm{E}-05$ & $3.2 \mathrm{E}-06$ & $6.3 \mathrm{E}-07$ & $1.2 \mathrm{E}-07$ \\
\hline$E$ & 20 & 1189 & GC & $0.0 \mathrm{E}+00$ & $0.0 \mathrm{E}+00$ & $0.0 \mathrm{E}+00$ & $0.0 \mathrm{E}+00$ & $0.0 \mathrm{E}+00$ & $0.0 \mathrm{E}+00$ & $1.9 \mathrm{E}-12$ & $5.4 \mathrm{E}-06$ & $5.7 \mathrm{E}-06$ & $1.3 \mathrm{E}-06$ & $3.2 \mathrm{E}-07$ \\
\hline
\end{tabular}


Table A.8. (contd)

\begin{tabular}{|c|c|c|c|c|c|c|c|c|c|c|c|c|c|c|}
\hline \multirow{2}{*}{$\begin{array}{c}\text { Stability } \\
\text { Class }\end{array}$} & \multirow{2}{*}{$\begin{array}{l}\text { Wind } \\
\text { Speed } \\
\mathrm{m} / \mathrm{s}\end{array}$} & \multirow{2}{*}{$\begin{array}{c}\text { Venting } \\
\text { Rate } \\
\text { m3/hr }\end{array}$} & \multirow[b]{2}{*}{ Conc. } & \multicolumn{3}{|c|}{ Distance Downwind, $\mathbf{m}$} & \multirow[b]{2}{*}{3} & \multirow[b]{2}{*}{10} & \multirow[b]{2}{*}{30} & \multirow[b]{2}{*}{100} & \multirow[b]{2}{*}{300} & \multirow[b]{2}{*}{1000} & \multirow[b]{2}{*}{3000} & \multirow[b]{2}{*}{10,000} \\
\hline & & & & 0.001 & 0.3 & 1 & & & & & & & & \\
\hline A & 1 & 1189 & $\mathrm{CC}$ & $1.0 \mathrm{E}+00$ & $9.6 \mathrm{E}-01$ & 7.1E-01 & $2.1 \mathrm{E}-01$ & $2.3 \mathrm{E}-02$ & $2.7 \mathrm{E}-03$ & $2.8 \mathrm{E}-04$ & $4.9 \mathrm{E}-05$ & $5.0 \mathrm{E}-06$ & $6.0 \mathrm{E}-07$ & $6.8 \mathrm{E}-08$ \\
\hline B & 1 & 1189 & $\mathrm{CC}$ & $1.0 \mathrm{E}+00$ & $9.8 \mathrm{E}-01$ & $8.5 \mathrm{E}-01$ & $3.8 \mathrm{E}-01$ & $5.2 \mathrm{E}-02$ & $6.1 \mathrm{E}-03$ & $5.5 \mathrm{E}-04$ & $9.7 \mathrm{E}-05$ & $1.1 \mathrm{E}-05$ & $1.4 \mathrm{E}-06$ & $1.5 \mathrm{E}-07$ \\
\hline $\mathrm{C}$ & 1 & 1189 & $\mathrm{CC}$ & $1.0 \mathrm{E}+00$ & $9.9 \mathrm{E}-01$ & $9.2 \mathrm{E}-01$ & 5.7E-01 & $1.1 \mathrm{E}-01$ & $1.3 \mathrm{E}-02$ & $1.2 \mathrm{E}-03$ & $1.8 \mathrm{E}-04$ & 2.6E-05 & $3.8 \mathrm{E}-06$ & $5.8 \mathrm{E}-07$ \\
\hline $\mathrm{D}$ & 1 & 1189 & $\mathrm{CC}$ & $1.0 \mathrm{E}+00$ & $1.0 \mathrm{E}+00$ & $9.6 \mathrm{E}-01$ & 7.1E-01 & $1.8 \mathrm{E}-01$ & $2.4 \mathrm{E}-02$ & $2.4 \mathrm{E}-03$ & $3.1 \mathrm{E}-04$ & $5.8 \mathrm{E}-05$ & $1.2 \mathrm{E}-05$ & 2.4E-06 \\
\hline $\bar{E}$ & 1 & 1189 & $\mathrm{CC}$ & $1.0 \mathrm{E}+00$ & $1.0 \mathrm{E}+00$ & $9.8 \mathrm{E}-01$ & $8.7 \mathrm{E}-01$ & $3.7 \mathrm{E}-01$ & $6.2 \mathrm{E}-02$ & $6.0 \mathrm{E}-03$ & 7.2E-04 & $1.0 \mathrm{E}-04$ & $2.4 \mathrm{E}-05$ & $6.2 \mathrm{E}-06$ \\
\hline$F$ & 1 & 1189 & $\mathrm{CC}$ & $1.0 \mathrm{E}+00$ & $1.0 \mathrm{E}+00$ & $9.9 \mathrm{E}-01$ & $9.5 \mathrm{E}-01$ & $6.2 \mathrm{E}-01$ & $1.6 \mathrm{E}-01$ & $1.7 \mathrm{E}-02$ & $2.0 \mathrm{E}-03$ & $2.3 \mathrm{E}-04$ & $5.2 \mathrm{E}-05$ & $1.5 \mathrm{E}-05$ \\
\hline A & 3.4 & 1189 & $\mathrm{CC}$ & $9.9 \mathrm{E}-01$ & $8.9 \mathrm{E}-01$ & $4.1 \mathrm{E}-01$ & 7.2E-02 & $7.0 \mathrm{E}-03$ & $7.8 \mathrm{E}-04$ & $8.2 \mathrm{E}-05$ & $1.4 \mathrm{E}-05$ & $1.5 \mathrm{E}-06$ & $1.8 \mathrm{E}-07$ & $2.0 \mathrm{E}-08$ \\
\hline B & 3.4 & 1189 & $\mathrm{CC}$ & $9.9 \mathrm{E}-01$ & $9.5 \mathrm{E}-01$ & $6.2 \mathrm{E}-01$ & $1.5 \mathrm{E}-01$ & $1.6 \mathrm{E}-02$ & $1.8 \mathrm{E}-03$ & $1.6 \mathrm{E}-04$ & $2.9 \mathrm{E}-05$ & $3.3 \mathrm{E}-06$ & $4.1 \mathrm{E}-07$ & $4.6 \mathrm{E}-08$ \\
\hline $\mathrm{C}$ & 3.4 & 1189 & $\mathrm{CC}$ & $1.0 \mathrm{E}+00$ & $9.7 \mathrm{E}-01$ & $7.8 \mathrm{E}-01$ & $2.8 \mathrm{E}-01$ & $3.4 \mathrm{E}-02$ & $3.9 \mathrm{E}-03$ & 3.6E-04 & $5.2 \mathrm{E}-05$ & 7.6E-06 & $1.1 \mathrm{E}-06$ & $1.7 \mathrm{E}-07$ \\
\hline $\mathrm{D}$ & 3.4 & 1189 & $\mathrm{CC}$ & $1.0 \mathrm{E}+00$ & $9.9 \mathrm{E}-01$ & $8.7 \mathrm{E}-01$ & $4.2 \mathrm{E}-01$ & $6.1 \mathrm{E}-02$ & $7.3 \mathrm{E}-03$ & $6.9 \mathrm{E}-04$ & $9.1 \mathrm{E}-05$ & $1.7 \mathrm{E}-05$ & $3.6 \mathrm{E}-06$ & $7.2 \mathrm{E}-07$ \\
\hline $\mathrm{E}$ & 3.4 & 1189 & $\mathrm{CC}$ & $1.0 \mathrm{E}+00$ & $9.9 \mathrm{E}-01$ & $9.4 \mathrm{E}-01$ & $6.6 \mathrm{E}-01$ & $1.5 \mathrm{E}-01$ & $1.9 \mathrm{E}-02$ & $1.8 \mathrm{E}-03$ & $2.1 \mathrm{E}-04$ & $3.0 \mathrm{E}-05$ & 7.1E-06 & $1.8 \mathrm{E}-06$ \\
\hline $\mathrm{F}$ & 3.4 & 1189 & $\mathrm{CC}$ & $1.0 \mathrm{E}+00$ & $1.0 \mathrm{E}+00$ & $9.8 \mathrm{E}-01$ & $8.4 \mathrm{E}-01$ & 3.3E-01 & $5.1 \mathrm{E}-02$ & $5.0 \mathrm{E}-03$ & 5.9E-04 & 6.6E-05 & $1.5 \mathrm{E}-05$ & $4.5 \mathrm{E}-06$ \\
\hline$G$ & 3.4 & 1189 & $\mathrm{CC}$ & $1.0 \mathrm{E}+00$ & $1.0 \mathrm{E}+00$ & $9.9 \mathrm{E}-01$ & 9.4E-01 & $5.7 \mathrm{E}-01$ & $1.3 \mathrm{E}-01$ & $1.4 \mathrm{E}-02$ & $1.7 \mathrm{E}-03$ & $1.8 \mathrm{E}-04$ & 3.3E-05 & $9.2 \mathrm{E}-06$ \\
\hline $\mathrm{C}$ & 10 & 1189 & $\mathrm{CC}$ & $9.9 \mathrm{E}-01$ & $9.3 \mathrm{E}-01$ & $5.4 \mathrm{E}-01$ & $1.2 \mathrm{E}-01$ & $1.2 \mathrm{E}-02$ & $1.3 \mathrm{E}-03$ & $1.2 \mathrm{E}-04$ & $1.8 \mathrm{E}-05$ & 2.6E-06 & $3.8 \mathrm{E}-07$ & $5.8 \mathrm{E}-08$ \\
\hline $\mathrm{D}$ & 10 & 1189 & $\overline{C C}$ & $1.0 \mathrm{E}+00$ & $9.6 \mathrm{E}-01$ & $6.9 \mathrm{E}-01$ & $2.0 \mathrm{E}-01$ & $2.2 \mathrm{E}-02$ & $2.5 \mathrm{E}-03$ & $2.4 \mathrm{E}-04$ & $3.1 \mathrm{E}-05$ & $5.8 \mathrm{E}-06$ & $1.2 \mathrm{E}-06$ & $2.4 \mathrm{E}-07$ \\
\hline $\mathrm{E}$ & 10 & 1189 & $\mathrm{CC}$ & $1.0 \mathrm{E}+00$ & $9.8 \mathrm{E}-01$ & $8.5 \mathrm{E}-01$ & $3.9 \mathrm{E}-01$ & $5.5 \mathrm{E}-02$ & $6.5 \mathrm{E}-03$ & $6.0 \mathrm{E}-04$ & $7.2 \mathrm{E}-05$ & $1.0 \mathrm{E}-05$ & $2.4 \mathrm{E}-06$ & $6.2 \mathrm{E}-07$ \\
\hline $\bar{C}$ & 20 & 1189 & $\mathrm{CC}$ & $9.8 \mathrm{E}-01$ & $8.7 \mathrm{E}-01$ & $3.7 \mathrm{E}-01$ & $6.2 \mathrm{E}-02$ & $5.9 \mathrm{E}-03$ & $6.7 \mathrm{E}-04$ & $6.1 \mathrm{E}-05$ & $8.8 \mathrm{E}-06$ & $1.3 \mathrm{E}-06$ & $1.9 \mathrm{E}-07$ & $2.9 \mathrm{E}-08$ \\
\hline $\mathrm{D}$ & 20 & 1189 & $\mathrm{CC}$ & $9.9 \mathrm{E}-01$ & $9.2 \mathrm{E}-01$ & $5.2 \mathrm{E}-01$ & $1.1 \mathrm{E}-01$ & $1.1 \mathrm{E}-02$ & $1.2 \mathrm{E}-03$ & $1.2 \mathrm{E}-04$ & $1.5 \mathrm{E}-05$ & $2.9 \mathrm{E}-06$ & $6.1 \mathrm{E}-07$ & $1.2 \mathrm{E}-07$ \\
\hline $\bar{E}$ & 20 & 1189 & $\overline{\mathrm{CC}}$ & $1.0 \mathrm{E}+00$ & $9.7 \mathrm{E}-01$ & 7.4E-01 & $2.5 \mathrm{E}-01$ & $2.8 \mathrm{E}-02$ & $3.3 \mathrm{E}-03$ & $3.0 \mathrm{E}-04$ & 3.6E-05 & $5.0 \mathrm{E}-06$ & $1.2 \mathrm{E}-06$ & $3.1 \mathrm{E}-07$ \\
\hline
\end{tabular}




\section{Appendix B}

\section{Passively Ventilated Vents Fractional Concentrations}


Table B.1. 4 Inch Pipe (Near-Surface); Fractional Concentrations at Ground Level Plume Centerline (CC)

\begin{tabular}{|c|c|c|c|c|c|c|c|c|c|c|c|c|c|c|}
\hline \multirow{2}{*}{$\begin{array}{c}\text { Stability } \\
\text { Class }\end{array}$} & \multirow{2}{*}{$\begin{array}{c}\text { Wind } \\
\text { Speed } \\
\mathbf{m} / \mathbf{s}\end{array}$} & \multirow{2}{*}{$\begin{array}{c}\text { Venting } \\
\text { Rate } \\
\text { m3/hr }\end{array}$} & \multirow[b]{2}{*}{ Conc. } & \multicolumn{2}{|c|}{ Distance Downwind, $\mathrm{m}$} & \multirow[b]{2}{*}{1} & \multirow[b]{2}{*}{3} & \multirow[b]{2}{*}{10} & \multirow[b]{2}{*}{30} & \multirow[b]{2}{*}{100} & \multirow[b]{2}{*}{300} & \multirow[b]{2}{*}{1000} & \multirow[b]{2}{*}{3000} & \multirow[b]{2}{*}{10,000} \\
\hline & & & & $\begin{array}{l}0.001 \\
\end{array}$ & 0.3 & & & & & & & & & \\
\hline $\mathrm{A}$ & 1.0 & 1 & $\mathrm{CC}$ & $1.7 \mathrm{E}-01$ & $2.2 \mathrm{E}-02$ & $2.0 \mathrm{E}-03$ & $3.6 \mathrm{E}-04$ & $3.9 \mathrm{E}-05$ & $4.5 \mathrm{E}-06$ & $4.0 \mathrm{E}-07$ & $4.5 \mathrm{E}-08$ & 4.2E-09 & $5.1 \mathrm{E}-10$ & $5.7 \mathrm{E}-11$ \\
\hline $\mathrm{B}$ & 1.0 & 1 & $\mathrm{CC}$ & $3.2 \mathrm{E}-01$ & 4.9E-02 & $4.6 \mathrm{E}-03$ & $6.3 \mathrm{E}-04$ & $8.7 \mathrm{E}-05$ & $1.0 \mathrm{E}-05$ & $9.3 \mathrm{E}-07$ & $1.0 \mathrm{E}-07$ & 9.7E-09 & $1.2 \mathrm{E}-09$ & $1.3 \mathrm{E}-10$ \\
\hline $\mathrm{C}$ & 1.0 & 1 & $\mathrm{CC}$ & $5.0 \mathrm{E}-01$ & $1.0 \mathrm{E}-01$ & $9.9 \mathrm{E}-03$ & $1.2 \mathrm{E}-03$ & $1.8 \mathrm{E}-04$ & $2.2 \mathrm{E}-05$ & $2.0 \mathrm{E}-06$ & 2.3E-07 & 2.3E-08 & $3.2 \mathrm{E}-09$ & $4.9 \mathrm{E}-10$ \\
\hline $\mathrm{D}$ & 1.0 & 1 & $\mathrm{CC}$ & $6.5 \mathrm{E}-01$ & $1.7 \mathrm{E}-01$ & $1.8 \mathrm{E}-02$ & $2.1 \mathrm{E}-03$ & $3.0 \mathrm{E}-04$ & $4.1 \mathrm{E}-05$ & 4.0E-06 & $5.0 \mathrm{E}-07$ & $6.1 \mathrm{E}-08$ & $1.1 \mathrm{E}-08$ & 2.1E-09 \\
\hline $\mathrm{E}$ & 1.0 & 1 & $\mathrm{CC}$ & 8.3E-01 & $3.5 \mathrm{E}-01$ & $4.7 \mathrm{E}-02$ & $5.4 \mathrm{E}-03$ & $5.5 \mathrm{E}-04$ & $9.9 \mathrm{E}-05$ & $1.0 \mathrm{E}-05$ & $1.2 \mathrm{E}-06$ & $1.3 \mathrm{E}-07$ & $2.4 \mathrm{E}-08$ & $5.6 \mathrm{E}-09$ \\
\hline $\mathrm{F}$ & 1.0 & 1 & $\mathrm{CC}$ & 9.3E-01 & $6.0 \mathrm{E}-01$ & $1.2 \mathrm{E}-01$ & $1.5 \mathrm{E}-02$ & $1.4 \mathrm{E}-03$ & $2.2 \mathrm{E}-04$ & $2.8 \mathrm{E}-05$ & $3.4 \mathrm{E}-06$ & $3.8 \mathrm{E}-07$ & 6.7E-08 & $1.6 \mathrm{E}-08$ \\
\hline G & 1.0 & 1 & $\mathrm{CC}$ & 9.7E-01 & 8.1E-01 & $2.8 \mathrm{E}-01$ & 4.1E-02 & 3.9E-03 & 4.6E-04 & 7.0E-05 & $9.3 \mathrm{E}-06$ & $1.0 \mathrm{E}-06$ & 1.9E-07 & 4.4E-08 \\
\hline A & 3.4 & 1 & $\mathrm{CC}$ & $5.6 \mathrm{E}-02$ & $6.5 \mathrm{E}-03$ & $6.0 \mathrm{E}-04$ & $1.0 \mathrm{E}-04$ & $1.2 \mathrm{E}-05$ & $1.3 \mathrm{E}-06$ & $1.2 \mathrm{E}-07$ & $1.3 \mathrm{E}-08$ & $1.2 \mathrm{E}-09$ & $1.5 \mathrm{E}-10$ & $1.7 \mathrm{E}-11$ \\
\hline B & 3.4 & 1 & $\mathrm{CC}$ & $1.2 \mathrm{E}-01$ & $1.5 \mathrm{E}-02$ & $1.4 \mathrm{E}-03$ & $1.9 \mathrm{E}-04$ & $2.5 \mathrm{E}-05$ & $3.0 \mathrm{E}-06$ & 2.7E-07 & $3.1 \mathrm{E}-08$ & 2.8E-09 & $3.4 \mathrm{E}-10$ & $3.8 \mathrm{E}-11$ \\
\hline $\mathrm{C}$ & 3.4 & 1 & $\mathrm{CC}$ & 2.3E-01 & $3.2 \mathrm{E}-02$ & 2.9E-03 & $3.4 \mathrm{E}-04$ & $5.2 \mathrm{E}-05$ & $6.5 \mathrm{E}-06$ & $6.0 \mathrm{E}-07$ & $6.9 \mathrm{E}-08$ & $6.8 \mathrm{E}-09$ & $9.5 \mathrm{E}-10$ & $1.4 \mathrm{E}-10$ \\
\hline $\mathrm{D}$ & 3.4 & 1 & $\mathrm{CC}$ & $3.5 \mathrm{E}-01$ & $5.7 \mathrm{E}-02$ & $5.4 \mathrm{E}-03$ & $6.0 \mathrm{E}-04$ & 8.7E-05 & $1.2 \mathrm{E}-05$ & $1.2 \mathrm{E}-06$ & $1.5 \mathrm{E}-07$ & $1.8 \mathrm{E}-08$ & 3.2E-09 & $6.1 \mathrm{E}-10$ \\
\hline $\mathrm{E}$ & 3.4 & 1 & $\mathrm{CC}$ & 5.9E-01 & $1.4 \mathrm{E}-01$ & $1.4 \mathrm{E}-02$ & $1.6 \mathrm{E}-03$ & $1.6 \mathrm{E}-04$ & $2.9 \mathrm{E}-05$ & $3.0 \mathrm{E}-06$ & $3.5 \mathrm{E}-07$ & 3.9E-08 & 7.0E-09 & 1.6E-09 \\
\hline $\mathrm{F}$ & 3.4 & 1 & $\mathrm{CC}$ & $8.0 \mathrm{E}-01$ & $3.1 \mathrm{E}-01$ & $3.9 \mathrm{E}-02$ & $4.5 \mathrm{E}-03$ & 4.1E-04 & $6.6 \mathrm{E}-05$ & $8.1 \mathrm{E}-06$ & 9.9E-07 & $1.1 \mathrm{E}-07$ & $2.0 \mathrm{E}-08$ & 4.6E-09 \\
\hline $\mathrm{G}$ & 3.4 & 1 & $\mathrm{CC}$ & 9.2E-01 & $5.5 \mathrm{E}-01$ & $1.0 \mathrm{E}-01$ & $1.2 \mathrm{E}-02$ & $1.1 \mathrm{E}-03$ & $1.3 \mathrm{E}-04$ & $2.1 \mathrm{E}-05$ & $2.7 \mathrm{E}-06$ & $3.1 \mathrm{E}-07$ & $5.5 \mathrm{E}-08$ & $1.3 \mathrm{E}-08$ \\
\hline $\mathrm{C}$ & 10.0 & 1 & $\mathrm{CC}$ & $9.1 \mathrm{E}-02$ & $1.1 \mathrm{E}-02$ & $1.0 \mathrm{E}-03$ & $1.2 \mathrm{E}-04$ & $1.8 \mathrm{E}-05$ & $2.2 \mathrm{E}-06$ & $2.0 \mathrm{E}-07$ & 2.3E-08 & $2.3 \mathrm{E}-09$ & $3.2 \mathrm{E}-10$ & 4.9E-11 \\
\hline $\mathrm{D}$ & 10.0 & 1 & $\mathrm{CC}$ & $1.6 \mathrm{E}-01$ & $2.0 \mathrm{E}-02$ & $1.8 \mathrm{E}-03$ & $2.1 \mathrm{E}-04$ & $3.0 \mathrm{E}-05$ & 4.1E-06 & 4.0E-07 & $5.0 \mathrm{E}-08$ & $6.1 \mathrm{E}-09$ & $1.1 \mathrm{E}-09$ & $2.1 \mathrm{E}-10$ \\
\hline $\mathrm{E}$ & 10.0 & 1 & $\mathrm{CC}$ & 3.3E-01 & $5.2 \mathrm{E}-02$ & 4.9E-03 & $5.5 \mathrm{E}-04$ & $5.5 \mathrm{E}-05$ & $9.9 \mathrm{E}-06$ & $1.0 \mathrm{E}-06$ & $1.2 \mathrm{E}-07$ & $1.3 \mathrm{E}-08$ & $2.4 \mathrm{E}-09$ & $5.6 \mathrm{E}-10$ \\
\hline $\mathrm{C}$ & 20.0 & 1 & $\mathrm{CC}$ & $4.8 \mathrm{E}-02$ & $5.6 \mathrm{E}-03$ & $5.0 \mathrm{E}-04$ & $5.8 \mathrm{E}-05$ & $8.8 \mathrm{E}-06$ & $1.1 \mathrm{E}-06$ & $1.0 \mathrm{E}-07$ & $1.2 \mathrm{E}-08$ & $1.2 \mathrm{E}-09$ & $1.6 \mathrm{E}-10$ & $2.5 \mathrm{E}-11$ \\
\hline $\mathrm{D}$ & 20.0 & 1 & $\mathrm{CC}$ & 8.4E-02 & $1.0 \mathrm{E}-02$ & $9.2 \mathrm{E}-04$ & $1.0 \mathrm{E}-04$ & $1.5 \mathrm{E}-05$ & $2.0 \mathrm{E}-06$ & $2.0 \mathrm{E}-07$ & $2.5 \mathrm{E}-08$ & 3.1E-09 & $5.5 \mathrm{E}-10$ & $1.0 \mathrm{E}-10$ \\
\hline $\mathrm{E}$ & 20.0 & 1 & $\mathrm{CC}$ & $2.0 \mathrm{E}-01$ & 2.7E-02 & $2.5 \mathrm{E}-03$ & $2.7 \mathrm{E}-04$ & $2.8 \mathrm{E}-05$ & 4.9E-06 & $5.0 \mathrm{E}-07$ & $6.0 \mathrm{E}-08$ & 6.7E-09 & $1.2 \mathrm{E}-09$ & $2.8 \mathrm{E}-10$ \\
\hline
\end{tabular}


Table B.1. ( contd)

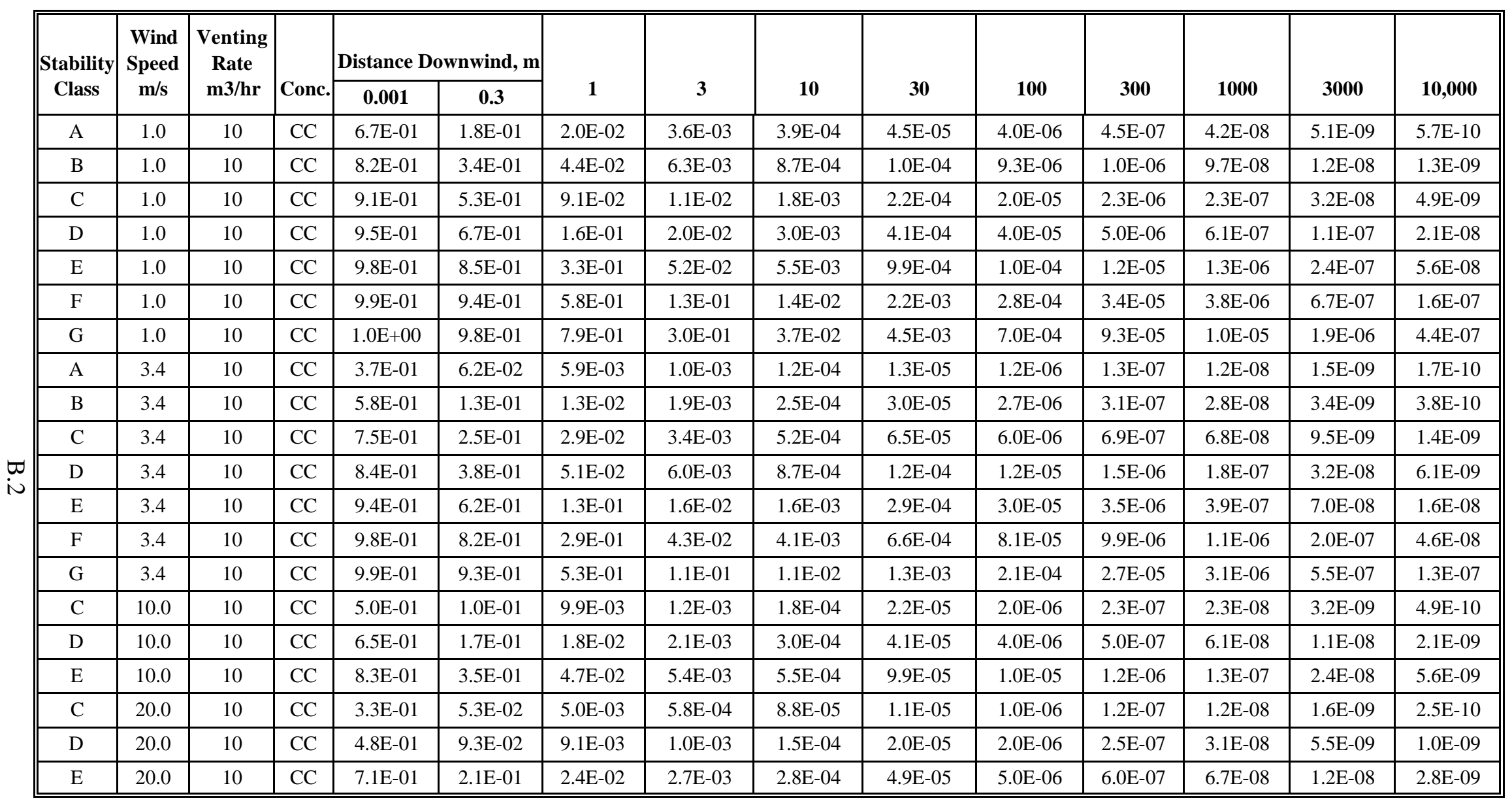


Table B.1. ( contd)

\begin{tabular}{|c|c|c|c|c|c|c|c|c|c|c|c|c|c|}
\hline \multirow{2}{*}{$\begin{array}{c}\text { Wind } \\
\text { Speed } \\
\text { m/s }\end{array}$} & \multirow{2}{*}{$\begin{array}{l}\text { Venting } \\
\text { Rate } \\
\text { m3/hr }\end{array}$} & \multirow{2}{*}{ Conc. } & \multicolumn{2}{|c|}{ Distance Downwind, $\mathbf{m}$} & \multirow[b]{2}{*}{1} & \multirow[b]{2}{*}{3} & \multirow[b]{2}{*}{10} & \multirow[b]{2}{*}{30} & \multirow[b]{2}{*}{100} & \multirow[b]{2}{*}{300} & \multirow[b]{2}{*}{1000} & \multirow[b]{2}{*}{3000} & \multirow[b]{2}{*}{10,000} \\
\hline & & & 0.001 & 0.3 & & & & & & & & & \\
\hline 1.0 & 100 & $\mathrm{CC}$ & $9.5 \mathrm{E}-01$ & $6.9 \mathrm{E}-01$ & $1.7 \mathrm{E}-01$ & $3.3 \mathrm{E}-02$ & $3.9 \mathrm{E}-03$ & $4.5 \mathrm{E}-04$ & $4.0 \mathrm{E}-05$ & 4.5E-06 & 4.2E-07 & $5.1 \mathrm{E}-08$ & $5.7 \mathrm{E}-09$ \\
\hline 1.0 & 100 & $\mathrm{CC}$ & $9.8 \mathrm{E}-01$ & $8.4 \mathrm{E}-01$ & $3.2 \mathrm{E}-01$ & $5.6 \mathrm{E}-02$ & $8.4 \mathrm{E}-03$ & $1.0 \mathrm{E}-03$ & $9.2 \mathrm{E}-05$ & $1.0 \mathrm{E}-05$ & $9.7 \mathrm{E}-07$ & $1.2 \mathrm{E}-07$ & $1.3 \mathrm{E}-08$ \\
\hline 1.0 & 100 & $\mathrm{CC}$ & $9.9 \mathrm{E}-01$ & $9.2 \mathrm{E}-01$ & $5.0 \mathrm{E}-01$ & $1.0 \mathrm{E}-01$ & $1.7 \mathrm{E}-02$ & $2.2 \mathrm{E}-03$ & $2.0 \mathrm{E}-04$ & 2.3E-05 & $2.3 \mathrm{E}-06$ & 3.2E-07 & $4.9 \mathrm{E}-08$ \\
\hline 1.0 & 100 & $\mathrm{CC}$ & $9.9 \mathrm{E}-01$ & $9.5 \mathrm{E}-01$ & $6.5 \mathrm{E}-01$ & $1.7 \mathrm{E}-01$ & $2.7 \mathrm{E}-02$ & $4.0 \mathrm{E}-03$ & $4.0 \mathrm{E}-04$ & $5.0 \mathrm{E}-05$ & $6.1 \mathrm{E}-06$ & $1.1 \mathrm{E}-06$ & $2.1 \mathrm{E}-07$ \\
\hline 1.0 & 100 & $\mathrm{CC}$ & $1.0 \mathrm{E}+00$ & $9.8 \mathrm{E}-01$ & 8.3E-01 & $3.5 \mathrm{E}-01$ & $5.0 \mathrm{E}-02$ & $9.5 \mathrm{E}-03$ & $1.0 \mathrm{E}-03$ & $1.2 \mathrm{E}-04$ & $1.3 \mathrm{E}-05$ & $2.4 \mathrm{E}-06$ & $5.6 \mathrm{E}-07$ \\
\hline 1.0 & 100 & $\mathrm{CC}$ & $1.0 \mathrm{E}+00$ & $9.9 \mathrm{E}-01$ & 9.3E-01 & $6.1 \mathrm{E}-01$ & $1.2 \mathrm{E}-01$ & $2.0 \mathrm{E}-02$ & $2.7 \mathrm{E}-03$ & $3.4 \mathrm{E}-04$ & $3.8 \mathrm{E}-05$ & $6.6 \mathrm{E}-06$ & $1.6 \mathrm{E}-06$ \\
\hline 1.0 & 100 & $\mathrm{CC}$ & $1.0 \mathrm{E}+00$ & $1.0 \mathrm{E}+00$ & $9.7 \mathrm{E}-01$ & $8.1 \mathrm{E}-01$ & $2.8 \mathrm{E}-01$ & $4.2 \mathrm{E}-02$ & $6.7 \mathrm{E}-03$ & $9.3 \mathrm{E}-04$ & $1.0 \mathrm{E}-04$ & $1.9 \mathrm{E}-05$ & 4.4E-06 \\
\hline 3.4 & 100 & $\mathrm{CC}$ & 8.6E-01 & 4.0E-01 & $5.6 \mathrm{E}-02$ & $9.8 \mathrm{E}-03$ & $1.1 \mathrm{E}-03$ & $1.3 \mathrm{E}-04$ & $1.2 \mathrm{E}-05$ & $1.3 \mathrm{E}-06$ & $1.2 \mathrm{E}-07$ & $1.5 \mathrm{E}-08$ & $1.7 \mathrm{E}-09$ \\
\hline 3.4 & 100 & $\mathrm{CC}$ & $9.3 \mathrm{E}-01$ & $6.0 \mathrm{E}-01$ & $1.2 \mathrm{E}-01$ & $1.7 \mathrm{E}-02$ & $2.5 \mathrm{E}-03$ & $3.0 \mathrm{E}-04$ & $2.7 \mathrm{E}-05$ & $3.1 \mathrm{E}-06$ & $2.8 \mathrm{E}-07$ & $3.4 \mathrm{E}-08$ & $3.8 \mathrm{E}-09$ \\
\hline 3.4 & 100 & $\mathrm{CC}$ & $9.7 \mathrm{E}-01$ & 7.7E-01 & 2.3E-01 & $3.2 \mathrm{E}-02$ & $4.9 \mathrm{E}-03$ & $6.5 \mathrm{E}-04$ & $6.0 \mathrm{E}-05$ & $6.9 \mathrm{E}-06$ & $6.8 \mathrm{E}-07$ & $9.5 \mathrm{E}-08$ & $1.4 \mathrm{E}-08$ \\
\hline 3.4 & 100 & $\mathrm{CC}$ & $9.8 \mathrm{E}-01$ & $8.6 \mathrm{E}-01$ & $3.5 \mathrm{E}-01$ & $5.7 \mathrm{E}-02$ & $8.1 \mathrm{E}-03$ & $1.2 \mathrm{E}-03$ & $1.2 \mathrm{E}-04$ & $1.5 \mathrm{E}-05$ & $1.8 \mathrm{E}-06$ & $3.2 \mathrm{E}-07$ & $6.1 \mathrm{E}-08$ \\
\hline 3.4 & 100 & $\mathrm{CC}$ & $9.9 \mathrm{E}-01$ & $9.4 \mathrm{E}-01$ & $5.9 \mathrm{E}-01$ & $1.4 \mathrm{E}-01$ & $1.5 \mathrm{E}-02$ & $2.8 \mathrm{E}-03$ & $2.9 \mathrm{E}-04$ & $3.5 \mathrm{E}-05$ & $3.9 \mathrm{E}-06$ & 7.0E-07 & $1.6 \mathrm{E}-07$ \\
\hline 3.4 & 100 & $\mathrm{CC}$ & $1.0 \mathrm{E}+00$ & $9.8 \mathrm{E}-01$ & $8.0 \mathrm{E}-01$ & 3.1E-01 & $3.9 \mathrm{E}-02$ & $6.0 \mathrm{E}-03$ & $8.0 \mathrm{E}-04$ & $9.9 \mathrm{E}-05$ & $1.1 \mathrm{E}-05$ & $2.0 \mathrm{E}-06$ & $4.6 \mathrm{E}-07$ \\
\hline 3.4 & 100 & $\mathrm{CC}$ & $1.0 \mathrm{E}+00$ & $9.9 \mathrm{E}-01$ & $9.2 \mathrm{E}-01$ & $5.6 \mathrm{E}-01$ & $1.0 \mathrm{E}-01$ & $1.3 \mathrm{E}-02$ & $2.0 \mathrm{E}-03$ & $2.7 \mathrm{E}-04$ & $3.1 \mathrm{E}-05$ & $5.5 \mathrm{E}-06$ & $1.3 \mathrm{E}-06$ \\
\hline 10.0 & 100 & $\mathrm{CC}$ & $9.1 \mathrm{E}-01$ & $5.3 \mathrm{E}-01$ & $9.1 \mathrm{E}-02$ & $1.1 \mathrm{E}-02$ & $1.7 \mathrm{E}-03$ & $2.2 \mathrm{E}-04$ & $2.0 \mathrm{E}-05$ & $2.3 \mathrm{E}-06$ & $2.3 \mathrm{E}-07$ & $3.2 \mathrm{E}-08$ & 4.9E-09 \\
\hline 10.0 & 100 & $\mathrm{CC}$ & $9.5 \mathrm{E}-01$ & $6.7 \mathrm{E}-01$ & $1.6 \mathrm{E}-01$ & $2.0 \mathrm{E}-02$ & $2.8 \mathrm{E}-03$ & $4.0 \mathrm{E}-04$ & $4.0 \mathrm{E}-05$ & $5.0 \mathrm{E}-06$ & $6.1 \mathrm{E}-07$ & $1.1 \mathrm{E}-07$ & $2.1 \mathrm{E}-08$ \\
\hline 10.0 & 100 & $\mathrm{CC}$ & $9.8 \mathrm{E}-01$ & $8.5 \mathrm{E}-01$ & $3.3 \mathrm{E}-01$ & $5.2 \mathrm{E}-02$ & $5.2 \mathrm{E}-03$ & $9.5 \mathrm{E}-04$ & $1.0 \mathrm{E}-04$ & $1.2 \mathrm{E}-05$ & $1.3 \mathrm{E}-06$ & $2.4 \mathrm{E}-07$ & $5.6 \mathrm{E}-08$ \\
\hline 20.0 & 100 & $\mathrm{CC}$ & $8.3 \mathrm{E}-01$ & 3.6E-01 & $4.8 \mathrm{E}-02$ & $5.6 \mathrm{E}-03$ & $8.4 \mathrm{E}-04$ & $1.1 \mathrm{E}-04$ & $1.0 \mathrm{E}-05$ & $1.2 \mathrm{E}-06$ & $1.2 \mathrm{E}-07$ & $1.6 \mathrm{E}-08$ & $2.5 \mathrm{E}-09$ \\
\hline 20.0 & 100 & $\mathrm{CC}$ & $9.0 \mathrm{E}-01$ & $5.1 \mathrm{E}-01$ & 8.4E-02 & $1.0 \mathrm{E}-02$ & $1.4 \mathrm{E}-03$ & $2.0 \mathrm{E}-04$ & $2.0 \mathrm{E}-05$ & $2.5 \mathrm{E}-06$ & $3.1 \mathrm{E}-07$ & $5.5 \mathrm{E}-08$ & $1.0 \mathrm{E}-08$ \\
\hline 20.0 & 100 & $\mathrm{CC}$ & $9.6 \mathrm{E}-01$ & 7.3E-01 & $2.0 \mathrm{E}-01$ & 2.7E-02 & $2.6 \mathrm{E}-03$ & $4.8 \mathrm{E}-04$ & $5.0 \mathrm{E}-05$ & $6.0 \mathrm{E}-06$ & $6.7 \mathrm{E}-07$ & $1.2 \mathrm{E}-07$ & $2.8 \mathrm{E}-08$ \\
\hline
\end{tabular}


Table B.2. Near-Surface Box Filter Vent; Fractional Concentrations at Ground Level Plume Centerline (CC)

\begin{tabular}{|c|c|c|c|c|c|c|c|c|c|c|c|c|c|c|}
\hline \multirow{2}{*}{$\begin{array}{c}\text { Stability } \\
\text { Class }\end{array}$} & \multirow{2}{*}{$\begin{array}{c}\text { Wind } \\
\text { Speed } \\
\mathbf{m} / \mathbf{s}\end{array}$} & \multirow{2}{*}{$\begin{array}{c}\text { Venting } \\
\text { Rate } \\
\text { m3/hr }\end{array}$} & \multirow[b]{2}{*}{ Conc. } & \multicolumn{2}{|c|}{ Distance Downwind, $\mathrm{m}$} & \multirow[b]{2}{*}{1} & \multirow[b]{2}{*}{3} & \multirow[b]{2}{*}{10} & \multirow[b]{2}{*}{30} & \multirow[b]{2}{*}{100} & \multirow[b]{2}{*}{300} & \multirow[b]{2}{*}{1000} & \multirow[b]{2}{*}{3000} & \multirow[b]{2}{*}{10,000} \\
\hline & & & & 0.001 & 0.3 & & & & & & & & & \\
\hline $\mathrm{A}$ & 1.0 & 1 & $\mathrm{CC}$ & $1.7 \mathrm{E}-01$ & $2.2 \mathrm{E}-02$ & $2.0 \mathrm{E}-03$ & $3.6 \mathrm{E}-04$ & $3.9 \mathrm{E}-05$ & $4.5 \mathrm{E}-06$ & $4.0 \mathrm{E}-07$ & $4.5 \mathrm{E}-08$ & $4.2 \mathrm{E}-09$ & $5.1 \mathrm{E}-10$ & $5.7 \mathrm{E}-11$ \\
\hline $\mathrm{B}$ & 1.0 & 1 & $\mathrm{CC}$ & $3.2 \mathrm{E}-01$ & $4.8 \mathrm{E}-02$ & $4.6 \mathrm{E}-03$ & $6.3 \mathrm{E}-04$ & $8.7 \mathrm{E}-05$ & $1.0 \mathrm{E}-05$ & $9.3 \mathrm{E}-07$ & $1.0 \mathrm{E}-07$ & $9.7 \mathrm{E}-09$ & $1.2 \mathrm{E}-09$ & $1.3 \mathrm{E}-10$ \\
\hline $\mathrm{C}$ & 1.0 & 1 & $\mathrm{CC}$ & $5.0 \mathrm{E}-01$ & $9.5 \mathrm{E}-02$ & $9.9 \mathrm{E}-03$ & $1.2 \mathrm{E}-03$ & $1.8 \mathrm{E}-04$ & $2.2 \mathrm{E}-05$ & $2.0 \mathrm{E}-06$ & $2.3 \mathrm{E}-07$ & $2.3 \mathrm{E}-08$ & $3.2 \mathrm{E}-09$ & $4.9 \mathrm{E}-10$ \\
\hline $\mathrm{D}$ & 1.0 & 1 & $\mathrm{CC}$ & $6.5 \mathrm{E}-01$ & $1.5 \mathrm{E}-01$ & $1.8 \mathrm{E}-02$ & $2.1 \mathrm{E}-03$ & $3.0 \mathrm{E}-04$ & $4.1 \mathrm{E}-05$ & $4.0 \mathrm{E}-06$ & $5.0 \mathrm{E}-07$ & $6.1 \mathrm{E}-08$ & $1.1 \mathrm{E}-08$ & $2.1 \mathrm{E}-09$ \\
\hline $\mathrm{E}$ & 1.0 & 1 & $\mathrm{CC}$ & $8.3 \mathrm{E}-01$ & $2.1 \mathrm{E}-01$ & $4.6 \mathrm{E}-02$ & $5.4 \mathrm{E}-03$ & $5.5 \mathrm{E}-04$ & 9.9E-05 & $1.0 \mathrm{E}-05$ & $1.2 \mathrm{E}-06$ & $1.3 \mathrm{E}-07$ & 2.4E-08 & $5.6 \mathrm{E}-09$ \\
\hline $\mathrm{F}$ & 1.0 & 1 & $\mathrm{CC}$ & $9.3 \mathrm{E}-01$ & $2.4 \mathrm{E}-01$ & $1.1 \mathrm{E}-01$ & $1.5 \mathrm{E}-02$ & $1.4 \mathrm{E}-03$ & $2.2 \mathrm{E}-04$ & $2.8 \mathrm{E}-05$ & $3.4 \mathrm{E}-06$ & $3.8 \mathrm{E}-07$ & $6.7 \mathrm{E}-08$ & $1.6 \mathrm{E}-08$ \\
\hline $\mathrm{G}$ & 1.0 & 1 & $\mathrm{CC}$ & 9.7E-01 & $2.4 \mathrm{E}-01$ & $2.0 \mathrm{E}-01$ & $4.1 \mathrm{E}-02$ & $3.9 \mathrm{E}-03$ & $4.6 \mathrm{E}-04$ & $7.0 \mathrm{E}-05$ & 9.3E-06 & $1.0 \mathrm{E}-06$ & $1.9 \mathrm{E}-07$ & $4.4 \mathrm{E}-08$ \\
\hline $\mathrm{A}$ & 3.4 & 1 & $\mathrm{CC}$ & $5.6 \mathrm{E}-02$ & $6.5 \mathrm{E}-03$ & $6.0 \mathrm{E}-04$ & $1.0 \mathrm{E}-04$ & $1.2 \mathrm{E}-05$ & $1.3 \mathrm{E}-06$ & $1.2 \mathrm{E}-07$ & $1.3 \mathrm{E}-08$ & $1.2 \mathrm{E}-09$ & $1.5 \mathrm{E}-10$ & $1.7 \mathrm{E}-11$ \\
\hline $\mathrm{B}$ & 3.4 & 1 & $\mathrm{CC}$ & $1.2 \mathrm{E}-01$ & $1.5 \mathrm{E}-02$ & $1.4 \mathrm{E}-03$ & $1.9 \mathrm{E}-04$ & $2.5 \mathrm{E}-05$ & $3.0 \mathrm{E}-06$ & $2.7 \mathrm{E}-07$ & $3.1 \mathrm{E}-08$ & $2.8 \mathrm{E}-09$ & $3.4 \mathrm{E}-10$ & $3.8 \mathrm{E}-11$ \\
\hline $\mathrm{C}$ & 3.4 & 1 & $\mathrm{CC}$ & $2.3 \mathrm{E}-01$ & $3.0 \mathrm{E}-02$ & $2.9 \mathrm{E}-03$ & $3.4 \mathrm{E}-04$ & $5.2 \mathrm{E}-05$ & $6.5 \mathrm{E}-06$ & $6.0 \mathrm{E}-07$ & $6.9 \mathrm{E}-08$ & $6.8 \mathrm{E}-09$ & $9.5 \mathrm{E}-10$ & $1.4 \mathrm{E}-10$ \\
\hline $\mathrm{D}$ & 3.4 & 1 & $\mathrm{CC}$ & $3.5 \mathrm{E}-01$ & $4.8 \mathrm{E}-02$ & $5.4 \mathrm{E}-03$ & $6.0 \mathrm{E}-04$ & $8.7 \mathrm{E}-05$ & $1.2 \mathrm{E}-05$ & $1.2 \mathrm{E}-06$ & $1.5 \mathrm{E}-07$ & $1.8 \mathrm{E}-08$ & $3.2 \mathrm{E}-09$ & $6.1 \mathrm{E}-10$ \\
\hline$E$ & 3.4 & 1 & $\mathrm{CC}$ & 5.9E-01 & $7.4 \mathrm{E}-02$ & $1.4 \mathrm{E}-02$ & $1.6 \mathrm{E}-03$ & $1.6 \mathrm{E}-04$ & $2.9 \mathrm{E}-05$ & $3.0 \mathrm{E}-06$ & $3.5 \mathrm{E}-07$ & $3.9 \mathrm{E}-08$ & $7.0 \mathrm{E}-09$ & $1.6 \mathrm{E}-09$ \\
\hline $\mathrm{F}$ & 3.4 & 1 & $\mathrm{CC}$ & $8.0 \mathrm{E}-01$ & $8.3 \mathrm{E}-02$ & $3.6 \mathrm{E}-02$ & $4.5 \mathrm{E}-03$ & $4.1 \mathrm{E}-04$ & $6.6 \mathrm{E}-05$ & $8.1 \mathrm{E}-06$ & 9.9E-07 & $1.1 \mathrm{E}-07$ & $2.0 \mathrm{E}-08$ & $4.6 \mathrm{E}-09$ \\
\hline $\mathrm{G}$ & 3.4 & 1 & $\mathrm{CC}$ & $9.2 \mathrm{E}-01$ & $8.5 \mathrm{E}-02$ & $6.7 \mathrm{E}-02$ & $1.2 \mathrm{E}-02$ & $1.1 \mathrm{E}-03$ & $1.3 \mathrm{E}-04$ & $2.1 \mathrm{E}-05$ & $2.7 \mathrm{E}-06$ & $3.1 \mathrm{E}-07$ & $5.5 \mathrm{E}-08$ & $1.3 \mathrm{E}-08$ \\
\hline $\mathrm{C}$ & 10.0 & 1 & $\mathrm{CC}$ & $9.1 \mathrm{E}-02$ & $1.0 \mathrm{E}-02$ & $1.0 \mathrm{E}-03$ & $1.2 \mathrm{E}-04$ & $1.8 \mathrm{E}-05$ & $2.2 \mathrm{E}-06$ & $2.0 \mathrm{E}-07$ & $2.3 \mathrm{E}-08$ & $2.3 \mathrm{E}-09$ & $3.2 \mathrm{E}-10$ & $4.9 \mathrm{E}-11$ \\
\hline $\mathrm{D}$ & 10.0 & 1 & $\mathrm{CC}$ & $1.6 \mathrm{E}-01$ & $1.7 \mathrm{E}-02$ & $1.8 \mathrm{E}-03$ & $2.1 \mathrm{E}-04$ & $3.0 \mathrm{E}-05$ & $4.1 \mathrm{E}-06$ & $4.0 \mathrm{E}-07$ & $5.0 \mathrm{E}-08$ & $6.1 \mathrm{E}-09$ & $1.1 \mathrm{E}-09$ & $2.1 \mathrm{E}-10$ \\
\hline $\mathrm{E}$ & 10.0 & 1 & $\mathrm{CC}$ & 3.3E-01 & $2.7 \mathrm{E}-02$ & $4.8 \mathrm{E}-03$ & 5.5E-04 & $5.5 \mathrm{E}-05$ & $9.9 \mathrm{E}-06$ & $1.0 \mathrm{E}-06$ & $1.2 \mathrm{E}-07$ & $1.3 \mathrm{E}-08$ & 2.4E-09 & $5.6 \mathrm{E}-10$ \\
\hline $\mathrm{C}$ & 20.0 & 1 & $\mathrm{CC}$ & $4.8 \mathrm{E}-02$ & $5.2 \mathrm{E}-03$ & $5.0 \mathrm{E}-04$ & $5.8 \mathrm{E}-05$ & $8.8 \mathrm{E}-06$ & $1.1 \mathrm{E}-06$ & $1.0 \mathrm{E}-07$ & $1.2 \mathrm{E}-08$ & $1.2 \mathrm{E}-09$ & $1.6 \mathrm{E}-10$ & $2.5 \mathrm{E}-11$ \\
\hline $\mathrm{D}$ & 20.0 & 1 & $\mathrm{CC}$ & $8.4 \mathrm{E}-02$ & $8.5 \mathrm{E}-03$ & 9.2E-04 & $1.0 \mathrm{E}-04$ & $1.5 \mathrm{E}-05$ & $2.0 \mathrm{E}-06$ & $2.0 \mathrm{E}-07$ & $2.5 \mathrm{E}-08$ & $3.1 \mathrm{E}-09$ & $5.5 \mathrm{E}-10$ & $1.0 \mathrm{E}-10$ \\
\hline$E$ & 20.0 & 1 & $\mathrm{CC}$ & $2.0 \mathrm{E}-01$ & $1.3 \mathrm{E}-02$ & $2.4 \mathrm{E}-03$ & 2.7E-04 & $2.8 \mathrm{E}-05$ & 4.9E-06 & 5.0E-07 & $6.0 \mathrm{E}-08$ & 6.7E-09 & 1.2E-09 & $2.8 \mathrm{E}-10$ \\
\hline
\end{tabular}


Table B.2. ( contd)

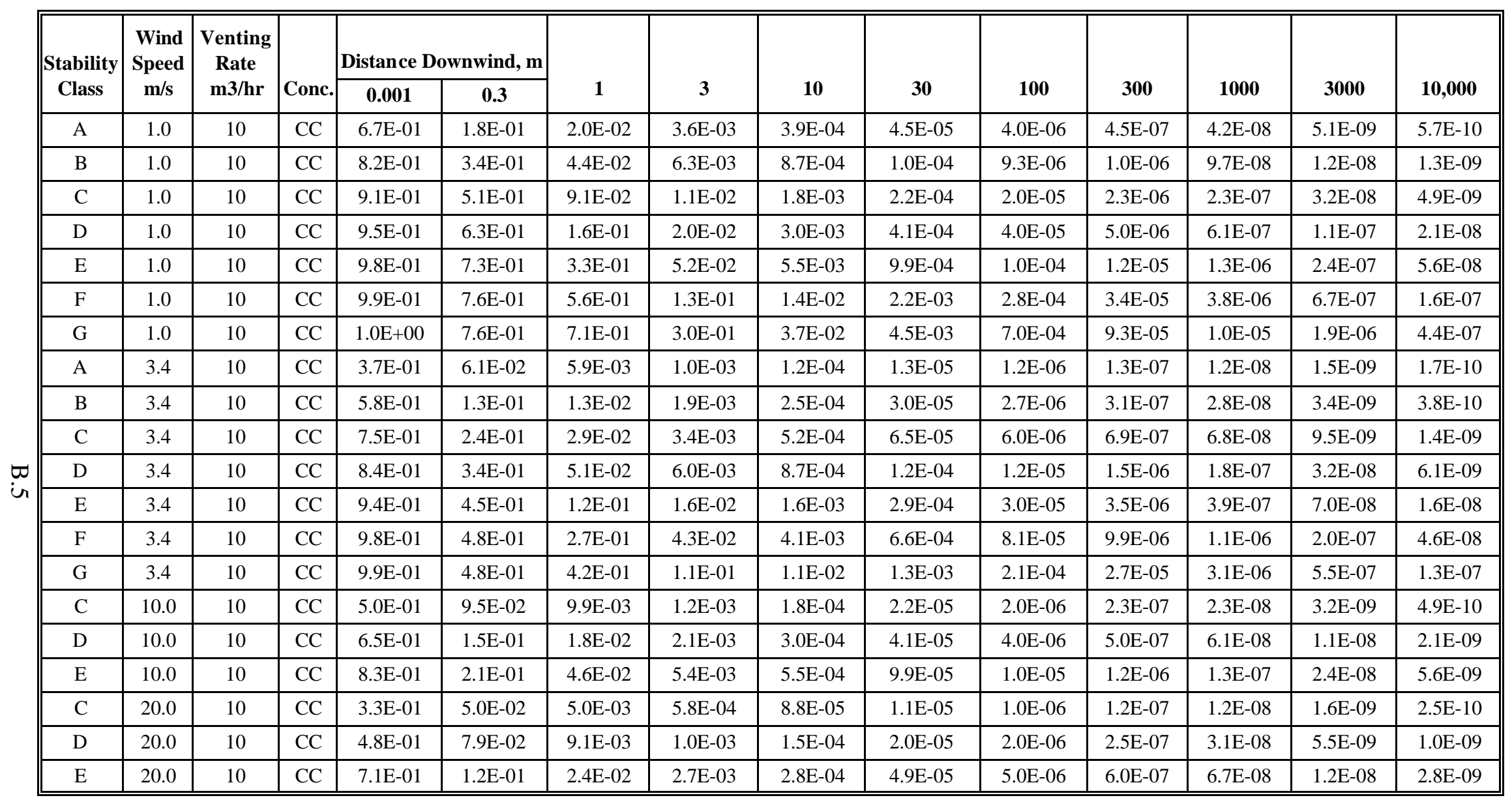


Table B.2. ( contd)

\begin{tabular}{|c|c|c|c|c|c|c|c|c|c|c|c|c|c|c|}
\hline \multirow{2}{*}{$\begin{array}{c}\text { Stability } \\
\text { Class }\end{array}$} & \multirow{2}{*}{$\begin{array}{c}\text { Wind } \\
\text { Speed } \\
\mathbf{m} / \mathbf{s}\end{array}$} & \multirow{2}{*}{$\begin{array}{c}\text { Venting } \\
\text { Rate } \\
\text { m3/hr }\end{array}$} & \multirow{2}{*}{ Conc. } & \multicolumn{2}{|c|}{ Distance Downwind, $\mathrm{m}$} & \multirow[b]{2}{*}{1} & \multirow[b]{2}{*}{3} & \multirow[b]{2}{*}{10} & \multirow[b]{2}{*}{30} & \multirow[b]{2}{*}{100} & \multirow[b]{2}{*}{300} & \multirow[b]{2}{*}{1000} & \multirow[b]{2}{*}{3000} & \multirow[b]{2}{*}{10,000} \\
\hline & & & & 0.001 & 0.3 & & & & & & & & & \\
\hline $\mathrm{A}$ & 1.0 & 100 & $\mathrm{CC}$ & $9.5 \mathrm{E}-01$ & $6.9 \mathrm{E}-01$ & $1.7 \mathrm{E}-01$ & $3.5 \mathrm{E}-02$ & $3.9 \mathrm{E}-03$ & $4.5 \mathrm{E}-04$ & $4.0 \mathrm{E}-05$ & $4.5 \mathrm{E}-06$ & $4.2 \mathrm{E}-07$ & $5.1 \mathrm{E}-08$ & $5.7 \mathrm{E}-09$ \\
\hline $\mathrm{B}$ & 1.0 & 100 & $\mathrm{CC}$ & $9.8 \mathrm{E}-01$ & $8.3 \mathrm{E}-01$ & $3.2 \mathrm{E}-01$ & $6.0 \mathrm{E}-02$ & $8.6 \mathrm{E}-03$ & $1.0 \mathrm{E}-03$ & $9.3 \mathrm{E}-05$ & $1.0 \mathrm{E}-05$ & $9.7 \mathrm{E}-07$ & $1.2 \mathrm{E}-07$ & $1.3 \mathrm{E}-08$ \\
\hline $\mathrm{C}$ & 1.0 & 100 & $\mathrm{CC}$ & $9.9 \mathrm{E}-01$ & $9.1 \mathrm{E}-01$ & $5.0 \mathrm{E}-01$ & $1.0 \mathrm{E}-01$ & $1.7 \mathrm{E}-02$ & $2.2 \mathrm{E}-03$ & $2.0 \mathrm{E}-04$ & $2.3 \mathrm{E}-05$ & $2.3 \mathrm{E}-06$ & $3.2 \mathrm{E}-07$ & $4.9 \mathrm{E}-08$ \\
\hline $\mathrm{D}$ & 1.0 & 100 & $\mathrm{CC}$ & 9.9E-01 & 9.4E-01 & $6.5 \mathrm{E}-01$ & $1.7 \mathrm{E}-01$ & $2.9 \mathrm{E}-02$ & $4.1 \mathrm{E}-03$ & $4.0 \mathrm{E}-04$ & $5.0 \mathrm{E}-05$ & $6.1 \mathrm{E}-06$ & $1.1 \mathrm{E}-06$ & $2.1 \mathrm{E}-07$ \\
\hline E & 1.0 & 100 & $\mathrm{CC}$ & $1.0 \mathrm{E}+00$ & $9.6 \mathrm{E}-01$ & 8.3E-01 & $3.5 \mathrm{E}-01$ & $5.3 \mathrm{E}-02$ & $9.8 \mathrm{E}-03$ & $1.0 \mathrm{E}-03$ & $1.2 \mathrm{E}-04$ & $1.3 \mathrm{E}-05$ & $2.4 \mathrm{E}-06$ & $5.6 \mathrm{E}-07$ \\
\hline $\mathrm{F}$ & 1.0 & 100 & $\mathrm{CC}$ & $1.0 \mathrm{E}+00$ & $9.7 \mathrm{E}-01$ & $9.3 \mathrm{E}-01$ & $6.1 \mathrm{E}-01$ & $1.2 \mathrm{E}-01$ & $2.2 \mathrm{E}-02$ & $2.8 \mathrm{E}-03$ & $3.4 \mathrm{E}-04$ & $3.8 \mathrm{E}-05$ & $6.7 \mathrm{E}-06$ & $1.6 \mathrm{E}-06$ \\
\hline $\mathrm{G}$ & 1.0 & 100 & $\mathrm{CC}$ & $1.0 \mathrm{E}+00$ & $9.7 \mathrm{E}-01$ & $9.6 \mathrm{E}-01$ & $8.1 \mathrm{E}-01$ & $2.8 \mathrm{E}-01$ & $4.4 \mathrm{E}-02$ & $7.0 \mathrm{E}-03$ & $9.3 \mathrm{E}-04$ & $1.0 \mathrm{E}-04$ & $1.9 \mathrm{E}-05$ & $4.4 \mathrm{E}-06$ \\
\hline $\mathrm{A}$ & 3.4 & 100 & $\mathrm{CC}$ & $8.6 \mathrm{E}-01$ & $4.0 \mathrm{E}-01$ & $5.6 \mathrm{E}-02$ & $1.0 \mathrm{E}-02$ & $1.2 \mathrm{E}-03$ & $1.3 \mathrm{E}-04$ & $1.2 \mathrm{E}-05$ & $1.3 \mathrm{E}-06$ & $1.2 \mathrm{E}-07$ & $1.5 \mathrm{E}-08$ & $1.7 \mathrm{E}-09$ \\
\hline B & 3.4 & 100 & $\mathrm{CC}$ & $9.3 \mathrm{E}-01$ & $6.0 \mathrm{E}-01$ & $1.2 \mathrm{E}-01$ & $1.8 \mathrm{E}-02$ & $2.5 \mathrm{E}-03$ & $3.0 \mathrm{E}-04$ & $2.7 \mathrm{E}-05$ & $3.1 \mathrm{E}-06$ & $2.8 \mathrm{E}-07$ & $3.4 \mathrm{E}-08$ & $3.8 \mathrm{E}-09$ \\
\hline $\mathrm{C}$ & 3.4 & 100 & $\mathrm{CC}$ & $9.7 \mathrm{E}-01$ & $7.6 \mathrm{E}-01$ & $2.3 \mathrm{E}-01$ & $3.3 \mathrm{E}-02$ & $5.2 \mathrm{E}-03$ & $6.5 \mathrm{E}-04$ & $6.0 \mathrm{E}-05$ & $6.9 \mathrm{E}-06$ & $6.8 \mathrm{E}-07$ & $9.5 \mathrm{E}-08$ & $1.4 \mathrm{E}-08$ \\
\hline $\mathrm{D}$ & 3.4 & 100 & $\mathrm{CC}$ & $9.8 \mathrm{E}-01$ & $8.3 \mathrm{E}-01$ & $3.5 \mathrm{E}-01$ & $5.7 \mathrm{E}-02$ & $8.6 \mathrm{E}-03$ & $1.2 \mathrm{E}-03$ & $1.2 \mathrm{E}-04$ & $1.5 \mathrm{E}-05$ & $1.8 \mathrm{E}-06$ & $3.2 \mathrm{E}-07$ & $6.1 \mathrm{E}-08$ \\
\hline $\mathrm{E}$ & 3.4 & 100 & $\mathrm{CC}$ & 9.9E-01 & $8.9 \mathrm{E}-01$ & $5.9 \mathrm{E}-01$ & $1.4 \mathrm{E}-01$ & $1.6 \mathrm{E}-02$ & $2.9 \mathrm{E}-03$ & $3.0 \mathrm{E}-04$ & $3.5 \mathrm{E}-05$ & $3.9 \mathrm{E}-06$ & $7.0 \mathrm{E}-07$ & $1.6 \mathrm{E}-07$ \\
\hline $\mathrm{F}$ & 3.4 & 100 & $\mathrm{CC}$ & $1.0 \mathrm{E}+00$ & $9.0 \mathrm{E}-01$ & 7.9E-01 & $3.1 \mathrm{E}-01$ & $3.9 \mathrm{E}-02$ & $6.5 \mathrm{E}-03$ & $8.1 \mathrm{E}-04$ & 9.9E-05 & $1.1 \mathrm{E}-05$ & $2.0 \mathrm{E}-06$ & 4.6E-07 \\
\hline $\mathrm{G}$ & 3.4 & 100 & $\mathrm{CC}$ & $1.0 \mathrm{E}+00$ & $9.0 \mathrm{E}-01$ & $8.8 \mathrm{E}-01$ & $5.6 \mathrm{E}-01$ & $1.0 \mathrm{E}-01$ & $1.3 \mathrm{E}-02$ & $2.1 \mathrm{E}-03$ & $2.7 \mathrm{E}-04$ & $3.1 \mathrm{E}-05$ & $5.5 \mathrm{E}-06$ & $1.3 \mathrm{E}-06$ \\
\hline $\mathrm{C}$ & 10.0 & 100 & $\mathrm{CC}$ & $9.1 \mathrm{E}-01$ & $5.1 \mathrm{E}-01$ & $9.1 \mathrm{E}-02$ & $1.1 \mathrm{E}-02$ & $1.8 \mathrm{E}-03$ & $2.2 \mathrm{E}-04$ & $2.0 \mathrm{E}-05$ & $2.3 \mathrm{E}-06$ & $2.3 \mathrm{E}-07$ & $3.2 \mathrm{E}-08$ & $4.9 \mathrm{E}-09$ \\
\hline $\mathrm{D}$ & 10.0 & 100 & $\mathrm{CC}$ & $9.5 \mathrm{E}-01$ & $6.3 \mathrm{E}-01$ & $1.6 \mathrm{E}-01$ & $2.0 \mathrm{E}-02$ & $3.0 \mathrm{E}-03$ & 4.1E-04 & $4.0 \mathrm{E}-05$ & $5.0 \mathrm{E}-06$ & $6.1 \mathrm{E}-07$ & $1.1 \mathrm{E}-07$ & $2.1 \mathrm{E}-08$ \\
\hline$E$ & 10.0 & 100 & $\mathrm{CC}$ & $9.8 \mathrm{E}-01$ & $7.3 \mathrm{E}-01$ & $3.3 \mathrm{E}-01$ & $5.2 \mathrm{E}-02$ & $5.5 \mathrm{E}-03$ & $9.9 \mathrm{E}-04$ & $1.0 \mathrm{E}-04$ & $1.2 \mathrm{E}-05$ & $1.3 \mathrm{E}-06$ & $2.4 \mathrm{E}-07$ & $5.6 \mathrm{E}-08$ \\
\hline $\mathrm{C}$ & 20.0 & 100 & $\mathrm{CC}$ & $8.3 \mathrm{E}-01$ & $3.4 \mathrm{E}-01$ & $4.8 \mathrm{E}-02$ & $5.8 \mathrm{E}-03$ & $8.8 \mathrm{E}-04$ & $1.1 \mathrm{E}-04$ & $1.0 \mathrm{E}-05$ & $1.2 \mathrm{E}-06$ & $1.2 \mathrm{E}-07$ & $1.6 \mathrm{E}-08$ & $2.5 \mathrm{E}-09$ \\
\hline $\mathrm{D}$ & 20.0 & 100 & $\mathrm{CC}$ & $9.0 \mathrm{E}-01$ & $4.6 \mathrm{E}-01$ & $8.4 \mathrm{E}-02$ & $1.0 \mathrm{E}-02$ & $1.5 \mathrm{E}-03$ & $2.0 \mathrm{E}-04$ & $2.0 \mathrm{E}-05$ & $2.5 \mathrm{E}-06$ & $3.1 \mathrm{E}-07$ & $5.5 \mathrm{E}-08$ & $1.0 \mathrm{E}-08$ \\
\hline$E$ & 20.0 & 100 & $\mathrm{CC}$ & $9.6 \mathrm{E}-01$ & $5.8 \mathrm{E}-01$ & $2.0 \mathrm{E}-01$ & $2.7 \mathrm{E}-02$ & $2.8 \mathrm{E}-03$ & 4.9E-04 & $5.0 \mathrm{E}-05$ & $6.0 \mathrm{E}-06$ & $6.7 \mathrm{E}-07$ & $1.2 \mathrm{E}-07$ & $2.8 \mathrm{E}-08$ \\
\hline
\end{tabular}


Table B.3. 4 Inch Pipe (Stack); Fractional Concentrations at Ground Level (GC) and Plume Centerline (CC)

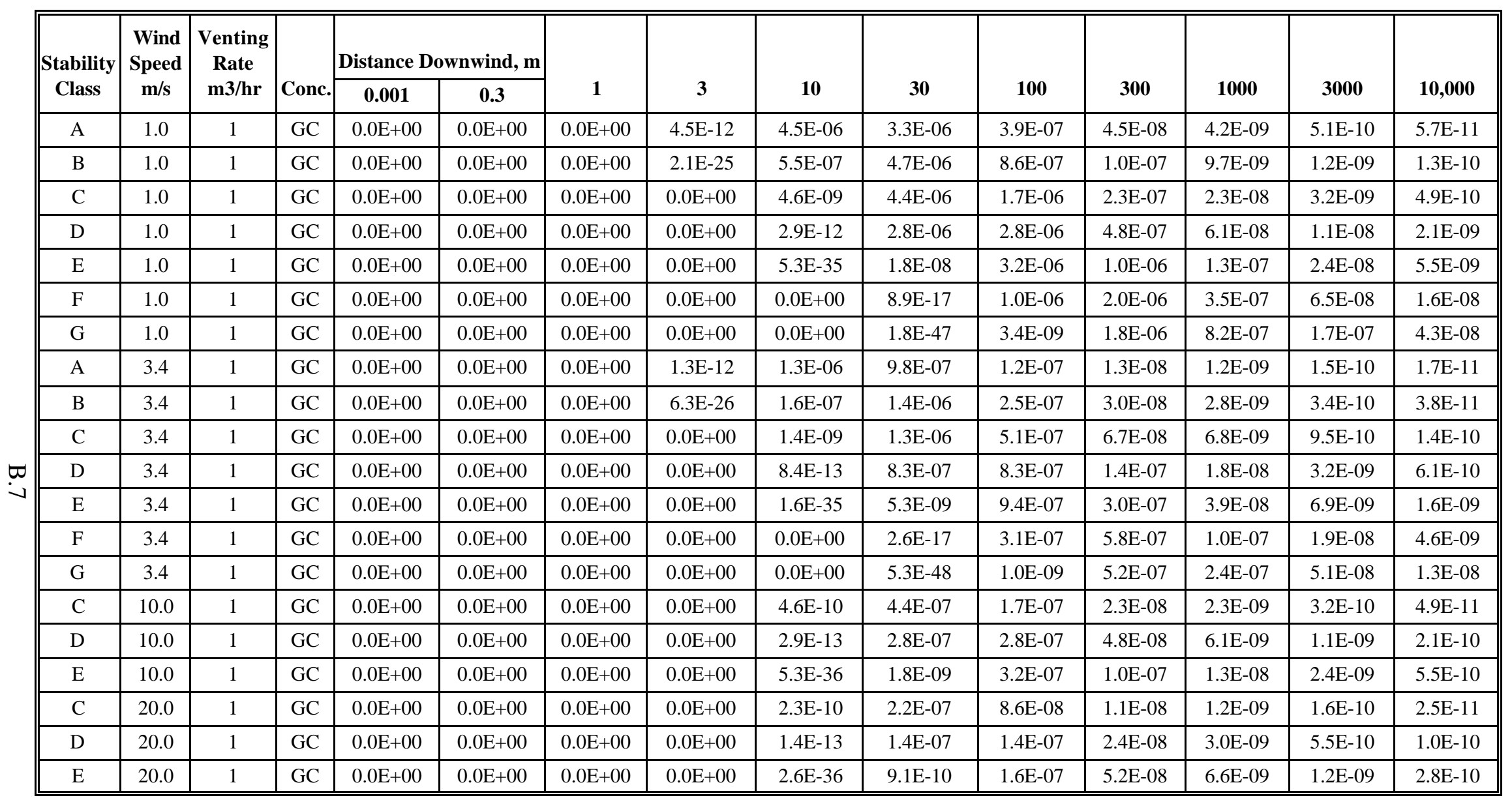


Table B.3. ( contd)

\begin{tabular}{|c|c|c|c|c|c|c|c|c|c|c|c|c|c|}
\hline \multirow{2}{*}{$\begin{array}{c}\text { Wind } \\
\text { Speed } \\
\mathbf{m} / \mathbf{s}\end{array}$} & \multirow{2}{*}{$\begin{array}{l}\text { Venting } \\
\text { Rate } \\
\text { m3/hr }\end{array}$} & \multirow{2}{*}{ Conc. } & \multicolumn{2}{|c|}{ Distance Downwind, $\mathbf{m}$} & \multirow[b]{2}{*}{1} & \multirow[b]{2}{*}{3} & \multirow[b]{2}{*}{10} & \multirow[b]{2}{*}{30} & \multirow[b]{2}{*}{100} & \multirow[b]{2}{*}{300} & \multirow[b]{2}{*}{1000} & \multirow[b]{2}{*}{3000} & \multirow[b]{2}{*}{10,000} \\
\hline & & & 0.001 & 0.3 & & & & & & & & & \\
\hline 1.0 & 1 & $\mathrm{CC}$ & $1.7 \mathrm{E}-01$ & $2.2 \mathrm{E}-02$ & $2.0 \mathrm{E}-03$ & $2.2 \mathrm{E}-04$ & $2.0 \mathrm{E}-05$ & $2.9 \mathrm{E}-06$ & $3.8 \mathrm{E}-07$ & $4.5 \mathrm{E}-08$ & 4.2E-09 & $5.1 \mathrm{E}-10$ & $5.7 \mathrm{E}-11$ \\
\hline 1.0 & 1 & $\mathrm{CC}$ & $3.2 \mathrm{E}-01$ & $4.9 \mathrm{E}-02$ & $4.6 \mathrm{E}-03$ & $5.1 \mathrm{E}-04$ & $4.6 \mathrm{E}-05$ & $5.3 \mathrm{E}-06$ & $8.1 \mathrm{E}-07$ & $1.0 \mathrm{E}-07$ & $9.6 \mathrm{E}-09$ & $1.2 \mathrm{E}-09$ & $1.3 \mathrm{E}-10$ \\
\hline 1.0 & 1 & $\mathrm{CC}$ & $5.0 \mathrm{E}-01$ & $1.0 \mathrm{E}-01$ & $9.9 \mathrm{E}-03$ & $1.1 \mathrm{E}-03$ & $1.0 \mathrm{E}-04$ & $1.1 \mathrm{E}-05$ & $1.5 \mathrm{E}-06$ & 2.2E-07 & $2.3 \mathrm{E}-08$ & 3.2E-09 & $4.9 \mathrm{E}-10$ \\
\hline 1.0 & 1 & $\mathrm{CC}$ & $6.5 \mathrm{E}-01$ & $1.7 \mathrm{E}-01$ & $1.8 \mathrm{E}-02$ & $2.0 \mathrm{E}-03$ & $1.9 \mathrm{E}-04$ & $2.1 \mathrm{E}-05$ & $2.5 \mathrm{E}-06$ & 4.6E-07 & $6.0 \mathrm{E}-08$ & $1.1 \mathrm{E}-08$ & $2.1 \mathrm{E}-09$ \\
\hline 1.0 & 1 & $\mathrm{CC}$ & 8.3E-01 & $3.5 \mathrm{E}-01$ & $4.7 \mathrm{E}-02$ & $5.4 \mathrm{E}-03$ & $4.9 \mathrm{E}-04$ & $5.5 \mathrm{E}-05$ & $5.1 \mathrm{E}-06$ & $9.3 \mathrm{E}-07$ & $1.3 \mathrm{E}-07$ & $2.3 \mathrm{E}-08$ & $5.5 \mathrm{E}-09$ \\
\hline 1.0 & 1 & $\mathrm{CC}$ & $9.3 \mathrm{E}-01$ & $6.0 \mathrm{E}-01$ & $1.2 \mathrm{E}-01$ & $1.5 \mathrm{E}-02$ & $1.4 \mathrm{E}-03$ & $1.6 \mathrm{E}-04$ & $1.4 \mathrm{E}-05$ & $1.9 \mathrm{E}-06$ & $3.3 \mathrm{E}-07$ & $6.4 \mathrm{E}-08$ & $1.5 \mathrm{E}-08$ \\
\hline 1.0 & 1 & $\mathrm{CC}$ & $9.7 \mathrm{E}-01$ & $8.1 \mathrm{E}-01$ & $2.8 \mathrm{E}-01$ & $4.1 \mathrm{E}-02$ & $3.9 \mathrm{E}-03$ & $4.3 \mathrm{E}-04$ & $4.0 \mathrm{E}-05$ & $4.7 \mathrm{E}-06$ & 7.2E-07 & $1.7 \mathrm{E}-07$ & 4.2E-08 \\
\hline 3.4 & 1 & $\mathrm{CC}$ & $5.6 \mathrm{E}-02$ & $6.5 \mathrm{E}-03$ & $5.9 \mathrm{E}-04$ & $6.6 \mathrm{E}-05$ & $5.9 \mathrm{E}-06$ & 8.6E-07 & $1.1 \mathrm{E}-07$ & $1.3 \mathrm{E}-08$ & $1.2 \mathrm{E}-09$ & $1.5 \mathrm{E}-10$ & $1.7 \mathrm{E}-11$ \\
\hline 3.4 & 1 & $\mathrm{CC}$ & $1.2 \mathrm{E}-01$ & $1.5 \mathrm{E}-02$ & $1.4 \mathrm{E}-03$ & $1.5 \mathrm{E}-04$ & $1.4 \mathrm{E}-05$ & $1.6 \mathrm{E}-06$ & $2.4 \mathrm{E}-07$ & $3.0 \mathrm{E}-08$ & $2.8 \mathrm{E}-09$ & $3.4 \mathrm{E}-10$ & $3.8 \mathrm{E}-11$ \\
\hline 3.4 & 1 & $\mathrm{CC}$ & $2.3 \mathrm{E}-01$ & $3.2 \mathrm{E}-02$ & $2.9 \mathrm{E}-03$ & 3.3E-04 & $3.0 \mathrm{E}-05$ & $3.3 \mathrm{E}-06$ & $4.5 \mathrm{E}-07$ & $6.6 \mathrm{E}-08$ & $6.8 \mathrm{E}-09$ & $9.5 \mathrm{E}-10$ & $1.4 \mathrm{E}-10$ \\
\hline 3.4 & 1 & $\mathrm{CC}$ & $3.5 \mathrm{E}-01$ & $5.7 \mathrm{E}-02$ & $5.4 \mathrm{E}-03$ & $6.0 \mathrm{E}-04$ & $5.5 \mathrm{E}-05$ & $6.2 \mathrm{E}-06$ & 7.4E-07 & $1.3 \mathrm{E}-07$ & $1.8 \mathrm{E}-08$ & $3.2 \mathrm{E}-09$ & $6.1 \mathrm{E}-10$ \\
\hline 3.4 & 1 & $\mathrm{CC}$ & $5.9 \mathrm{E}-01$ & $1.4 \mathrm{E}-01$ & $1.4 \mathrm{E}-02$ & $1.6 \mathrm{E}-03$ & $1.4 \mathrm{E}-04$ & $1.6 \mathrm{E}-05$ & $1.5 \mathrm{E}-06$ & $2.7 \mathrm{E}-07$ & $3.8 \mathrm{E}-08$ & $6.9 \mathrm{E}-09$ & $1.6 \mathrm{E}-09$ \\
\hline 3.4 & 1 & $\mathrm{CC}$ & $8.0 \mathrm{E}-01$ & $3.1 \mathrm{E}-01$ & $3.9 \mathrm{E}-02$ & $4.5 \mathrm{E}-03$ & 4.1E-04 & 4.6E-05 & $4.2 \mathrm{E}-06$ & $5.6 \mathrm{E}-07$ & $9.7 \mathrm{E}-08$ & $1.9 \mathrm{E}-08$ & $4.5 \mathrm{E}-09$ \\
\hline 3.4 & 1 & $\mathrm{CC}$ & $9.2 \mathrm{E}-01$ & $5.5 \mathrm{E}-01$ & $1.0 \mathrm{E}-01$ & $1.2 \mathrm{E}-02$ & $1.1 \mathrm{E}-03$ & $1.3 \mathrm{E}-04$ & $1.2 \mathrm{E}-05$ & $1.4 \mathrm{E}-06$ & $2.1 \mathrm{E}-07$ & $4.9 \mathrm{E}-08$ & $1.2 \mathrm{E}-08$ \\
\hline 10.0 & 1 & $\mathrm{CC}$ & $9.1 \mathrm{E}-02$ & $1.1 \mathrm{E}-02$ & $1.0 \mathrm{E}-03$ & $1.1 \mathrm{E}-04$ & $1.0 \mathrm{E}-05$ & $1.1 \mathrm{E}-06$ & $1.5 \mathrm{E}-07$ & $2.2 \mathrm{E}-08$ & $2.3 \mathrm{E}-09$ & $3.2 \mathrm{E}-10$ & $4.9 \mathrm{E}-11$ \\
\hline 10.0 & 1 & $\mathrm{CC}$ & $1.6 \mathrm{E}-01$ & $2.0 \mathrm{E}-02$ & $1.8 \mathrm{E}-03$ & $2.1 \mathrm{E}-04$ & $1.9 \mathrm{E}-05$ & $2.1 \mathrm{E}-06$ & $2.5 \mathrm{E}-07$ & $4.6 \mathrm{E}-08$ & $6.0 \mathrm{E}-09$ & $1.1 \mathrm{E}-09$ & $2.1 \mathrm{E}-10$ \\
\hline 10.0 & 1 & $\mathrm{CC}$ & $3.3 \mathrm{E}-01$ & $5.2 \mathrm{E}-02$ & $4.9 \mathrm{E}-03$ & $5.5 \mathrm{E}-04$ & $4.9 \mathrm{E}-05$ & $5.5 \mathrm{E}-06$ & $5.1 \mathrm{E}-07$ & 9.3E-08 & $1.3 \mathrm{E}-08$ & 2.3E-09 & $5.5 \mathrm{E}-10$ \\
\hline 20.0 & 1 & $\mathrm{CC}$ & $4.8 \mathrm{E}-02$ & $5.6 \mathrm{E}-03$ & $5.0 \mathrm{E}-04$ & $5.6 \mathrm{E}-05$ & $5.0 \mathrm{E}-06$ & $5.6 \mathrm{E}-07$ & 7.7E-08 & $1.1 \mathrm{E}-08$ & $1.1 \mathrm{E}-09$ & $1.6 \mathrm{E}-10$ & $2.5 \mathrm{E}-11$ \\
\hline 20.0 & 1 & $\mathrm{CC}$ & $8.4 \mathrm{E}-02$ & $1.0 \mathrm{E}-02$ & $9.2 \mathrm{E}-04$ & $1.0 \mathrm{E}-04$ & $9.3 \mathrm{E}-06$ & $1.0 \mathrm{E}-06$ & $1.3 \mathrm{E}-07$ & $2.3 \mathrm{E}-08$ & 3.0E-09 & $5.5 \mathrm{E}-10$ & $1.0 \mathrm{E}-10$ \\
\hline 20.0 & 1 & $\mathrm{CC}$ & $2.0 \mathrm{E}-01$ & 2.7E-02 & $2.5 \mathrm{E}-03$ & 2.7E-04 & $2.5 \mathrm{E}-05$ & $2.8 \mathrm{E}-06$ & 2.6E-07 & 4.7E-08 & 6.4E-09 & $1.2 \mathrm{E}-09$ & $2.8 \mathrm{E}-10$ \\
\hline
\end{tabular}


Table B.3. (contd)

\begin{tabular}{|c|c|c|c|c|c|c|c|c|c|c|c|c|c|c|}
\hline & \multirow{2}{*}{$\begin{array}{c}\text { Wind } \\
\text { Speed } \\
\mathrm{m} / \mathrm{s}\end{array}$} & \multirow{2}{*}{$\begin{array}{c}\text { Venting } \\
\text { Rate } \\
\text { m3/hr }\end{array}$} & \multirow{2}{*}{ Conc. } & \multicolumn{2}{|c|}{ Distance Downwind, $\mathbf{m}$} & \multirow[b]{2}{*}{1} & \multirow[b]{2}{*}{3} & \multirow[b]{2}{*}{10} & \multirow[b]{2}{*}{30} & \multirow[b]{2}{*}{100} & \multirow[b]{2}{*}{300} & \multirow[b]{2}{*}{1000} & \multirow[b]{2}{*}{3000} & \multirow[b]{2}{*}{10,000} \\
\hline & & & & 0.001 & 0.3 & & & & & & & & & \\
\hline 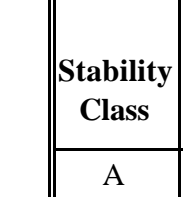 & 1.0 & 10 & GC & $0.0 \mathrm{E}+00$ & $0.0 \mathrm{E}+00$ & $0.0 \mathrm{E}+00$ & $4.5 \mathrm{E}-11$ & $4.5 \mathrm{E}-05$ & $3.3 \mathrm{E}-05$ & $3.9 \mathrm{E}-06$ & $4.5 \mathrm{E}-07$ & $4.2 \mathrm{E}-08$ & $5.1 \mathrm{E}-09$ & $5.7 \mathrm{E}-10$ \\
\hline $\mathrm{B}$ & 1.0 & 10 & GC & $0.0 \mathrm{E}+00$ & $0.0 \mathrm{E}+00$ & $0.0 \mathrm{E}+00$ & $2.1 \mathrm{E}-24$ & $5.5 \mathrm{E}-06$ & $4.7 \mathrm{E}-05$ & $8.6 \mathrm{E}-06$ & $1.0 \mathrm{E}-06$ & 9.7E-08 & $1.2 \mathrm{E}-08$ & $1.3 \mathrm{E}-09$ \\
\hline $\mathrm{C}$ & 1.0 & 10 & $\mathrm{GC}$ & $0.0 \mathrm{E}+00$ & $0.0 \mathrm{E}+00$ & $0.0 \mathrm{E}+00$ & $0.0 \mathrm{E}+00$ & 4.6E-08 & 4.4E-05 & $1.7 \mathrm{E}-05$ & $2.3 \mathrm{E}-06$ & $2.3 \mathrm{E}-07$ & $3.2 \mathrm{E}-08$ & 4.9E-09 \\
\hline $\mathrm{D}$ & 1.0 & 10 & GC & $0.0 \mathrm{E}+00$ & $0.0 \mathrm{E}+00$ & $0.0 \mathrm{E}+00$ & $0.0 \mathrm{E}+00$ & $2.9 \mathrm{E}-11$ & $2.8 \mathrm{E}-05$ & $2.8 \mathrm{E}-05$ & $4.8 \mathrm{E}-06$ & $6.1 \mathrm{E}-07$ & $1.1 \mathrm{E}-07$ & $2.1 \mathrm{E}-08$ \\
\hline E & 1.0 & 10 & $\mathrm{GC}$ & $0.0 \mathrm{E}+00$ & $0.0 \mathrm{E}+00$ & $0.0 \mathrm{E}+00$ & $0.0 \mathrm{E}+00$ & 5.3E-34 & $1.8 \mathrm{E}-07$ & $3.2 \mathrm{E}-05$ & $1.0 \mathrm{E}-05$ & $1.3 \mathrm{E}-06$ & 2.4E-07 & $5.5 \mathrm{E}-08$ \\
\hline $\mathrm{F}$ & 1.0 & 10 & GC & $0.0 \mathrm{E}+00$ & $0.0 \mathrm{E}+00$ & $0.0 \mathrm{E}+00$ & $0.0 \mathrm{E}+00$ & $0.0 \mathrm{E}+00$ & $8.9 \mathrm{E}-16$ & $1.0 \mathrm{E}-05$ & $2.0 \mathrm{E}-05$ & $3.5 \mathrm{E}-06$ & $6.5 \mathrm{E}-07$ & $1.6 \mathrm{E}-07$ \\
\hline G & 1.0 & 10 & $\mathrm{GC}$ & $0.0 \mathrm{E}+00$ & $0.0 \mathrm{E}+00$ & $0.0 \mathrm{E}+00$ & $0.0 \mathrm{E}+00$ & $0.0 \mathrm{E}+00$ & $1.8 \mathrm{E}-46$ & 3.4E-08 & $1.8 \mathrm{E}-05$ & $8.2 \mathrm{E}-06$ & $1.7 \mathrm{E}-06$ & 4.3E-07 \\
\hline A & 3.4 & 10 & $\mathrm{GC}$ & $0.0 \mathrm{E}+00$ & $0.0 \mathrm{E}+00$ & $0.0 \mathrm{E}+00$ & $1.3 \mathrm{E}-11$ & $1.3 \mathrm{E}-05$ & $9.8 \mathrm{E}-06$ & $1.2 \mathrm{E}-06$ & $1.3 \mathrm{E}-07$ & $1.2 \mathrm{E}-08$ & $1.5 \mathrm{E}-09$ & $1.7 \mathrm{E}-10$ \\
\hline $\mathrm{B}$ & 3.4 & 10 & GC & $0.0 \mathrm{E}+00$ & $0.0 \mathrm{E}+00$ & $0.0 \mathrm{E}+00$ & $6.3 \mathrm{E}-25$ & $1.6 \mathrm{E}-06$ & $1.4 \mathrm{E}-05$ & $2.5 \mathrm{E}-06$ & $3.0 \mathrm{E}-07$ & $2.8 \mathrm{E}-08$ & 3.4E-09 & 3.8E-10 \\
\hline $\mathrm{C}$ & 3.4 & 10 & $\mathrm{GC}$ & $0.0 \mathrm{E}+00$ & $0.0 \mathrm{E}+00$ & $0.0 \mathrm{E}+00$ & $0.0 \mathrm{E}+00$ & $1.4 \mathrm{E}-08$ & $1.3 \mathrm{E}-05$ & $5.1 \mathrm{E}-06$ & $6.7 \mathrm{E}-07$ & $6.8 \mathrm{E}-08$ & $9.5 \mathrm{E}-09$ & $1.4 \mathrm{E}-09$ \\
\hline $\mathrm{D}$ & 3.4 & 10 & GC & $0.0 \mathrm{E}+00$ & $0.0 \mathrm{E}+00$ & $0.0 \mathrm{E}+00$ & $0.0 \mathrm{E}+00$ & $8.4 \mathrm{E}-12$ & $8.3 \mathrm{E}-06$ & $8.3 \mathrm{E}-06$ & $1.4 \mathrm{E}-06$ & $1.8 \mathrm{E}-07$ & 3.2E-08 & $6.1 \mathrm{E}-09$ \\
\hline $\mathrm{E}$ & 3.4 & 10 & GC & $0.0 \mathrm{E}+00$ & $0.0 \mathrm{E}+00$ & $0.0 \mathrm{E}+00$ & $0.0 \mathrm{E}+00$ & $1.6 \mathrm{E}-34$ & $5.3 \mathrm{E}-08$ & $9.4 \mathrm{E}-06$ & $3.0 \mathrm{E}-06$ & $3.9 \mathrm{E}-07$ & $6.9 \mathrm{E}-08$ & $1.6 \mathrm{E}-08$ \\
\hline $\mathrm{F}$ & 3.4 & 10 & GC & $0.0 \mathrm{E}+00$ & $0.0 \mathrm{E}+00$ & $0.0 \mathrm{E}+00$ & $0.0 \mathrm{E}+00$ & $0.0 \mathrm{E}+00$ & 2.6E-16 & 3.1E-06 & $5.8 \mathrm{E}-06$ & $1.0 \mathrm{E}-06$ & $1.9 \mathrm{E}-07$ & 4.6E-08 \\
\hline G & 3.4 & 10 & GC & $0.0 \mathrm{E}+00$ & $0.0 \mathrm{E}+00$ & $0.0 \mathrm{E}+00$ & $0.0 \mathrm{E}+00$ & $0.0 \mathrm{E}+00$ & 5.3E-47 & $1.0 \mathrm{E}-08$ & $5.2 \mathrm{E}-06$ & 2.4E-06 & $5.1 \mathrm{E}-07$ & $1.3 \mathrm{E}-07$ \\
\hline $\mathrm{C}$ & 10.0 & 10 & GC & $0.0 \mathrm{E}+00$ & $0.0 \mathrm{E}+00$ & $0.0 \mathrm{E}+00$ & $0.0 \mathrm{E}+00$ & 4.6E-09 & 4.4E-06 & $1.7 \mathrm{E}-06$ & $2.3 \mathrm{E}-07$ & 2.3E-08 & 3.2E-09 & $4.9 \mathrm{E}-10$ \\
\hline $\mathrm{D}$ & 10.0 & 10 & GC & $0.0 \mathrm{E}+00$ & $0.0 \mathrm{E}+00$ & $0.0 \mathrm{E}+00$ & $0.0 \mathrm{E}+00$ & $2.9 \mathrm{E}-12$ & $2.8 \mathrm{E}-06$ & $2.8 \mathrm{E}-06$ & $4.8 \mathrm{E}-07$ & $6.1 \mathrm{E}-08$ & $1.1 \mathrm{E}-08$ & 2.1E-09 \\
\hline E & 10.0 & 10 & GC & $0.0 \mathrm{E}+00$ & $0.0 \mathrm{E}+00$ & $0.0 \mathrm{E}+00$ & $0.0 \mathrm{E}+00$ & 5.3E-35 & $1.8 \mathrm{E}-08$ & 3.2E-06 & $1.0 \mathrm{E}-06$ & $1.3 \mathrm{E}-07$ & 2.4E- 08 & 5.5E-09 \\
\hline $\mathrm{C}$ & 20.0 & 10 & GC & $0.0 \mathrm{E}+00$ & $0.0 \mathrm{E}+00$ & $0.0 \mathrm{E}+00$ & $0.0 \mathrm{E}+00$ & 2.3E-09 & 2.2E-06 & 8.6E-07 & $1.1 \mathrm{E}-07$ & $1.2 \mathrm{E}-08$ & $1.6 \mathrm{E}-09$ & 2.5E-10 \\
\hline D & 20.0 & 10 & GC & $0.0 \mathrm{E}+00$ & $0.0 \mathrm{E}+00$ & $0.0 \mathrm{E}+00$ & $0.0 \mathrm{E}+00$ & $1.4 \mathrm{E}-12$ & $1.4 \mathrm{E}-06$ & $1.4 \mathrm{E}-06$ & 2.4E-07 & 3.0E-08 & $5.5 \mathrm{E}-09$ & 1.0E-09 \\
\hline E & 20.0 & 10 & GC & $0.0 \mathrm{E}+00$ & $0.0 \mathrm{E}+00$ & $0.0 \mathrm{E}+00$ & $0.0 \mathrm{E}+00$ & $2.6 \mathrm{E}-35$ & $9.1 \mathrm{E}-09$ & $1.6 \mathrm{E}-06$ & $5.2 \mathrm{E}-07$ & $6.6 \mathrm{E}-08$ & $1.2 \mathrm{E}-08$ & 2.8E-09 \\
\hline
\end{tabular}


Table B.3. (contd)

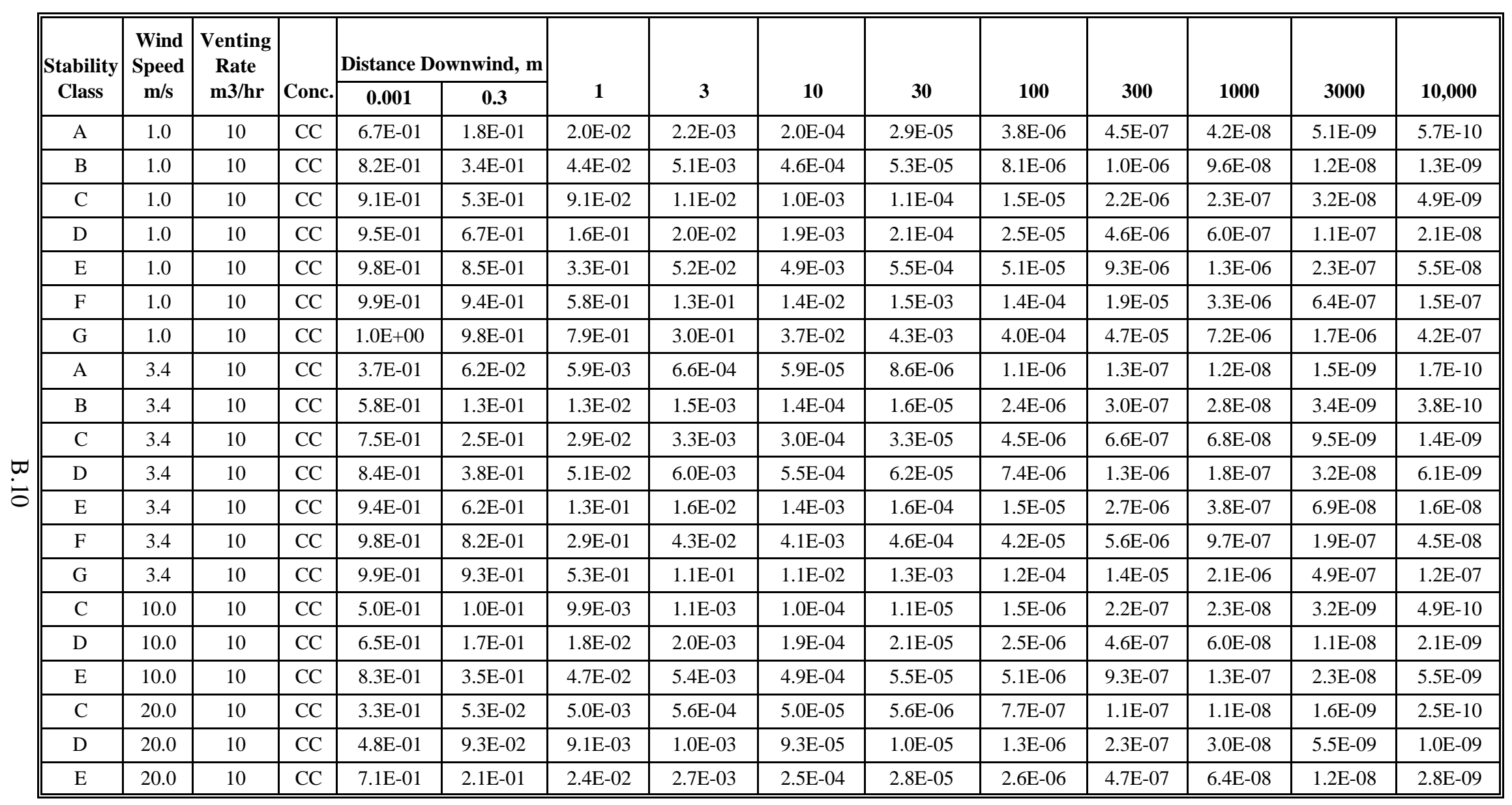


Table B.3. (contd)

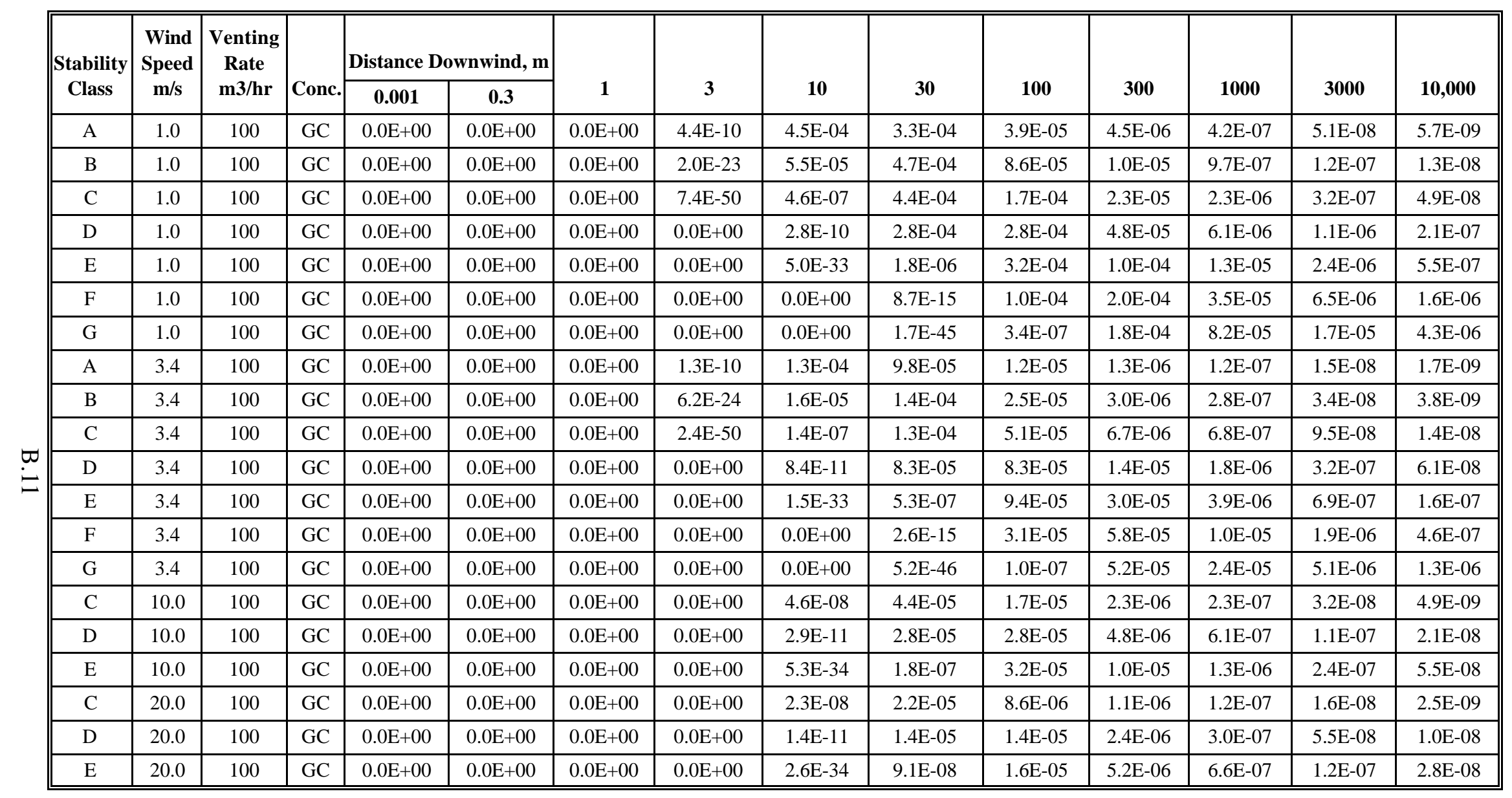


Table B.3. (contd)

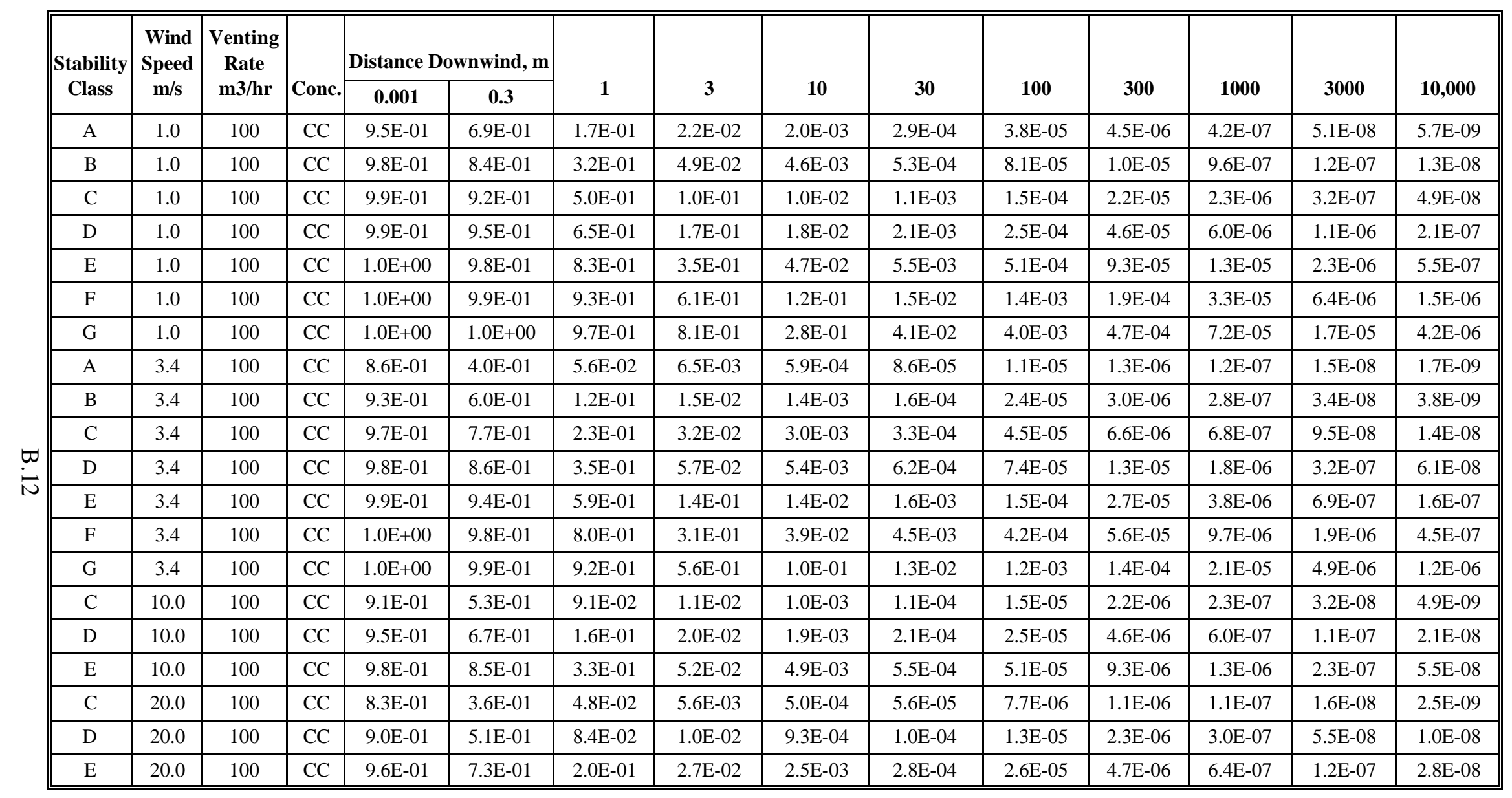




\section{Distribution}

No. of

\section{Copies}

ONSITE

18 PNNL

J. G. Droppo (10)

K9-30

J. L. Huckaby (5)

L. A. Mahoney

J. V. Ramsdell

J. A. Glissmeyer

31 CH2M HILL Hanford Group, Inc.

D. I. Allen

J. E. Meacham

R. J. Cash

J. O. Honeyman (5)

A. Sastry

M. T. Hughey

L. L. Johns-Andersch

J. W. Jabara

G. L. McLellan

N. W. Kirch

W. B. Barton
No. of

Copies

D. A. Reynolds

S7-90

J. M. Faurote

H6-62

M. J. Hocking

H6-62

J. S. Schofield

S7-12

W. L. Cowley

R1-44

M. L. Zabel

R1-06

R. L. Higgins

R2-50

T. J. Anderson

R2-50

E. J. Cruz

R3-86

G. Crawford

R3-86

R. Ni

H6-03

S. J. Eberlein

C. DeFigh-Price

$\mathrm{H} 603$

R2-58

R2-58

R. S. Popielczyk

S7-70

H6-62

J. G. Field

H6-07

S7-83

R2-50

S7-83

R3-86

R2-58

S7-70
3 U.S. Department of Energy

J. H. Swailes

H6-60

R. C. Barr

D. L. Noyes
H6-60

H6-60

Distr.1 